UNIVERSIDADE DE SÃO PAULO

INSTITUTO DE PSICOLOGIA

GUSTAVO XAVIER FERREIRA DA SILVA

MEMÓRIA SOCIAL DE PARTICIPANTES DE COMUNIDADES

ECLESIAIS DE BASE EM SANTO ANDRÉ

(Versão Corrigida) 
GUSTAVO XAVIER FERREIRA DA SILVA

\section{MEMÓRIA SOCIAL DE PARTICIPANTES DE COMUNIDADES ECLESIAIS DE BASE EM SANTO ANDRÉ}

(Versão Corrigida)

Dissertação apresentada ao Instituto de Psicologia da Universidade de São Paulo como parte dos requisitos para a obtenção do título de Mestre em Psicologia.

Área de Concentração: Psicologia Social

Orientadora: Prof ${ }^{a}$ Livre-Docente Sueli

Damergian 
AUTORIZO A REPRODUÇÃO E DIVULGAÇÃO TOTAL OU PARCIAL DESTE TRABALHO, POR QUALQUER MEIO CONVENCIONAL OU ELETRÔNICO, PARA FINS DE ESTUDO E PESQUISA, DESDE QUE CITADA A FONTE.

Catalogação na publicação Biblioteca Dante Moreira Leite

Instituto de Psicologia da Universidade de São Paulo

Silva, Gustavo Xavier Ferreira da.

Memória social de participantes de Comunidades Eclesiais de Base em Santo André / Gustavo Xavier Ferreira da Silva; orientadora Sueli Damergian. -- São Paulo, 2012.

$230 \mathrm{f}$.

Dissertação (Mestrado - Programa de Pós-Graduação em Psicologia. Área de Concentração: Psicologia Social) - Instituto de Psicologia da Universidade de São Paulo.

1. Memória social 2. Comunidades Eclesiais de Base 3. História oral 4. Psicologia Social 5. Igreja Católica 6. Teologia da Libertação I. Título.

HM251 
Nome: SILVA, Gustavo Xavier Ferreira da

Título: Memória social de participantes de Comunidades Eclesiais de Base em Santo André

Dissertação apresentada ao Instituto de Psicologia da Universidade de São Paulo para obtenção do título de Mestre em Psicologia.

Aprovado em:

Banca Examinadora

Prof. Dr.:

Instituição:

Julgamento:

Assinatura:

Prof. Dr.: Instituição:

Julgamento: Assinatura:

Prof. Dr.: Instituição:

Julgamento: Assinatura: 


\section{DEDICATÓRIA}

Ao padre Mahon que, com sua vida, vem sendo grande inspirador de organizações populares e de atitudes proféticas entre gerações.

Ao padre Alfredinho que, oferecendo-se como sofredor junto aos mais sofredores, despertou-lhes um profundo sentido de vida.

A tantos oprimidos que, ao longo da história, desafiam a dominação e semeiam comunitariamente a esperança. 


\section{AGRADECIMENTOS}

À minha amada Regina, que é generosidade, apoio, sorriso, paciência, abraço, pés no chão, enfim, minha companheira. Este trabalho está aquecido por seu colo.

Aos meus pais, que fizeram tanto pela minha formação - em todos os sentidos - e que estão sempre confiantes em potencialidades que eu sequer suspeito em mim.

Aos meus irmãos: Clarissa e seu esposo Mário. Com eles, sempre me lembro da inquebrantável relação entre fé e confiança na vida.

Aos queridos Ronaldo e Rosana, Rejany e Anderson, Milena e toda a família que cultivou a Regina e que, agora, me oferta a alegria da convivência.

À minha orientadora, Sueli Damergian, a quem agradeço de coração por me acolher, assim como a este projeto, dando incentivo e força. Sinal de amorosidade.

Aos professores Paulo de Salles Oliveira e Paulo César Carneiro Lopes, pela generosa participação desde a banca de qualificação, com recomendações, questionamentos e indicações preciosas.

Aos padres Félix, Luiz e Mahon, que me acolheram, abriram caminhos e, de modo especial, me deixaram entrar em suas vidas. $\mathrm{O}$ apoio e carinho de vocês foi alicerce deste trabalho.

A todos os companheiros e companheiras da Paróquia São Geraldo e de suas comunidades. Suas vidas alimentam todo este trabalho e estão presentes em cada linha.

Aos companheiros e companheiras de CEBs, JOC, ACO, PO, Irmandade do Servo Sofredor, e de tantos outros grupos de tantos outros lugares. Nossa convivência tem sido um ponto de inflexão em minha trajetória. 
Ao casal João e Geralda, em nome dos quais agradeço a tantas outras famílias e pessoas que dedicaram horas maravilhosas de conversas, lembranças e, muitas vezes, disponibilizaram seus arquivos pessoais.

Ao amigo Martin Resendez Islas, svd, que tanto fez por este trabalho, principalmente nas urgências, na disponibilização de materiais difíceis e, é claro, na partilha de horizontes.

Aos amigos Eduardo e Andrea, Rogério e Ana, e Bruna, pela simples e, no entanto, tão grandiosa oferta: a amizade. Gratuidade e afeto acompanham suas presenças.

Aos amigos do MIRE. Nossas experiências juntos continuam sendo inspiração até hoje.

Aos companheiros e companheiras do Núcleo Augusto Boal, que seguraram as pontas com toda a generosidade, entendendo todas as necessidades de dedicação à pesquisa.

Aos companheiros de trabalho dos últimos anos que deram apoio como puderam e, especialmente, a Pedro Ortiz, que foi altamente compreensivo e respeitoso quanto às necessidades deste percurso.

Aos funcionários do Instituto de Psicologia da USP e, especialmente, os do Departamento de Psicologia Social, pela solicitude, pelas orientações e pela disponibilidade atenciosa.

Aos meus avós e bisavós que, com suas narrativas, despertaram-me para o sabor delicioso da memória.

A Jesus de Nazaré, que com sua radical proposta de promover a vida, arriscou-se de modo tão corajoso. Em sua vida transparecem as melhores potencialidades humanas.

Finalmente, agradeço a este Deus que caminha na brisa da tarde, o Pai Nosso: solo do amor, fonte de vida, impulso à luminosidade, ponta de nossos sonhos e mais... 
É Jesus este pão de igualdade

Viemos pra comungar

Com a luta sofrida do povo

Que quer ter voz, ter vez, lugar.

Comungar é tornar-se um perigo

Viemos pra incomodar

Com a fé e a união nossos passos

Um dia vão chegar.

(Canto - Cecília Vaz Castilho, Se calarem a voz dos profetas)

Tudo o que já foi, é o começo do que vai vir, toda a hora a gente está num cômpito. (Riobaldo Tatarana, em Grande sertão: veredas)

Pai Nosso revolucionário

Parceiro dos pobres

Deus dos oprimidos.

(Canto - Cireneu Kuhn, Pai Nosso dos mártires) 
SILVA, G. X. F. Memória social de participantes de Comunidades Eclesiais de Base em

Santo André. 2012. Dissertação (Mestrado) - Instituto de Psicologia, Universidade de São

Paulo, São Paulo, 2012.

\section{RESUMO}

O presente trabalho é um estudo sobre as memórias de participantes de Comunidades Eclesiais de Base (CEBs) numa região paroquial de Santo André. Trata-se de tentar compreender as relações dialéticas entre a vida social e a subjetividade das pessoas que narram suas lembranças. Foi escolhido o procedimento de história oral de vida, a fim de captar o conjunto das experiências vividas, desde a infância até o momento presente, ao longo de suas trajetórias e reconstruídas na narrativa memorial de cada um. Os narradores percorrem suas lembranças, unindo-as a reflexões, avaliações, explicações e interpretações que tendem à formação de um sentido totalizante de vida. A fé, os compromissos sociais e políticos, os espaços, as relações sociais, os desenvolvimentos humanos, as respostas às dificuldades, os valores, o trabalho, as relações com o tempo e com os testemunhos pessoais, são alguns dos aspectos destacados das memórias neste estudo. O pesquisador constrói, com os narradores, algumas reflexões acerca dos aspectos que emergem das memórias, tendo a companhia de autores como Ecléa Bosi, Maurice Halbwachs, Karl Marx, István Mészáros, José Moura G. Filho, Guimarães Rosa, os teólogos da libertação, entre outros. O estudo teve como eixo 4 sujeitos e suas histórias de vida, enriquecidas por observações em espaços diversos e convivências com muitos outros participantes de movimentos e grupos afins às CEBs, especialmente no $\mathrm{ABC}$.

Palavras-chave: Memória social. Comunidades Eclesiais de Base. Histórias de vida. Psicologia Social. Igreja Católica. Teologia da Libertação. 
SILVA, G. X. F. Social memory of the participants of Basic Ecclesial Communities in

Santo André. 2012. Dissertation (Master's Degree) - Instituto de Psicologia, Universidade de São Paulo, São Paulo, 2012.

\begin{abstract}
This study is about the memories of the participants of Basic Ecclesial Communities (BECs) in a parish area in Santo André. The aim of this work is to understand the dialectical relationship between social life and the subjectivity of the persons who narrate their recollections. In order to capture the totality of life experiences from childhood until the present time (as they are rebuilt in the individual memorial narrative), the method employed is oral history of life. Narrators travel through their memories and unite them to reflections, critical evaluations, explanations and interpretations which tend to form a totalizing sense of life. Aspects as faith, political and social commitments, social relations and spaces, human developments, responses when faced with difficulties, values, work and the relationship with time and personal testimonies have all emerged from the recollections here gathered. The researcher builds some reflections with the narrators about the elements which arise from their narrated memories, resorting to authors such as Ecléa Bosi, Maurice Halbwachs, Karl Marx, István Mészáros, José Moura G. Filho, Guimarães Rosa, liberation theologists and others. This study is based on four individuals and their life histories and was enriched by observations in several different spaces and by the close personal relationship with many other militants of groups and movements related to the BECs, particularly in the region of $\mathrm{ABC}$.
\end{abstract}

Keywords: Social memory. Basic Ecclesial Communities. Life histories. Social Psychology. Roman Catholic Church. Liberation Theology. 


\section{LISTA DE SIGLAS}

ACO Ação Católica Operária

ADC Associação das Donas de Casa

ARENA Aliança Renovadora Nacional

CEBs Comunidades Eclesiais de Base

CNBB Conferência Nacional dos Bispos do Brasil

ISSO Irmandade do Servo Sofredor

JOC Juventude Operária Católica

MDB Movimento Democrático Brasileiro

MR-8 Movimento Revolucionário 8 de Outubro

PC do B Partido Comunista do Brasil

PO Pastoral Operária

PT Partido dos Trabalhadores

Semasa Serviço Municipal de Saneamento Ambiental de Santo André 


\section{SUMÁRIO}

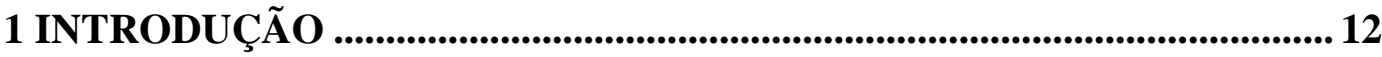

$1.1 \mathrm{O}$ tema e seu contexto .............................................................................. 12

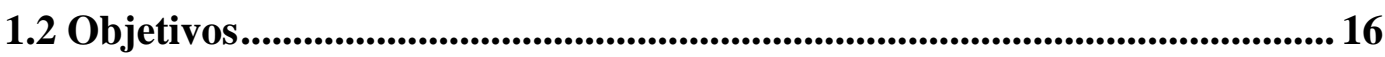

2 ORIENTAÇÕES DO ESTUDO - COMPANHEIROS TEÓRICOS ........... 17

3 CONSIDERAÇÕES METODOLÓGICAS .................................................... 22

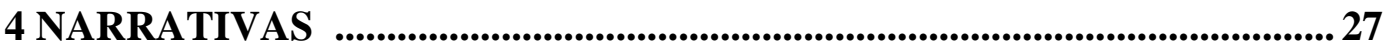

4.1 Madalena ........................................................................................................................... 27

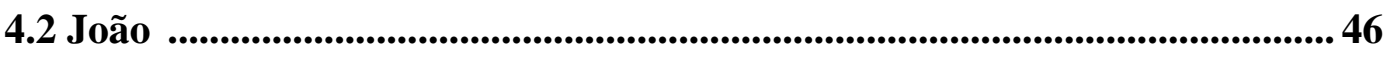

4.3 Margarida .......................................................................................................... 94

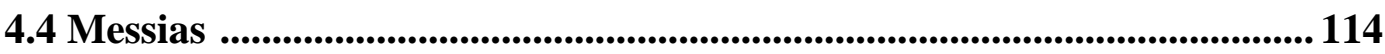

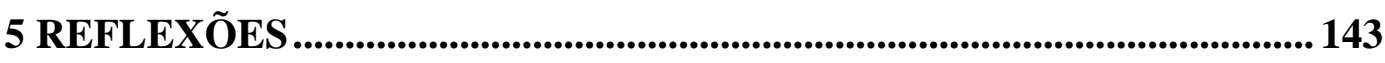

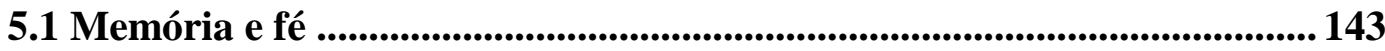

5.1.1 Sagrado no mundo, sentido na vida, tudo religado .............................. 143

5.1.2 Fé e compromisso ........................................................................................... 151

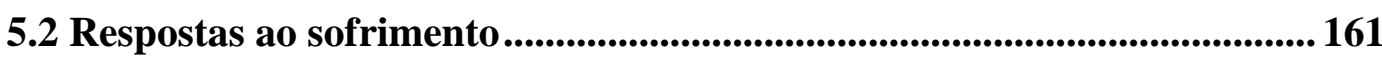

5.2.1 Enfrentamento da humilhação social........................................................ 161

5.2.2 Lutas ........................................................................................ 165

5.2.3 Luta e repressão .......................................................................... 169

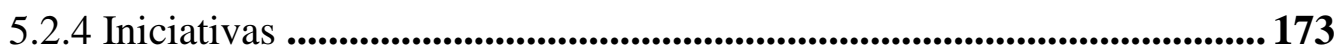

5.3 Figuras de referência......................................................................... 176

5.4 Memória e solidariedade...................................................................... 184

5.5 Pessoas, espaços, pessoas... (lugar das gentes) ............................................. 190

5.6 Memória em três tempos....................................................................................... 197

5.7 Memória e trabalho................................................................................................. 205

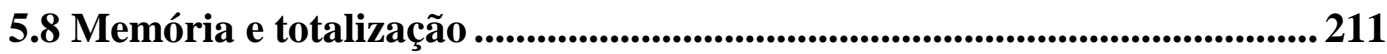

REFERÊNCIAS CITADAS .......................................................................... 219

REFERÊNCIAS CONSULTADAS ........................................................ 222

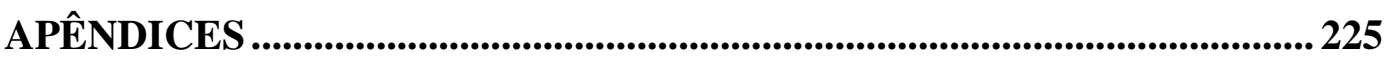

APÊNDICE A - Roteiro-piloto de entrevista ........................................... 225

APÊNDICE B - Roteiro de entrevista ....................................................222

APÊNDICE C - Modelo de Termo de Consentimento ................................2229

APÊNDICE D - Modelo de Revisão do Termo de Consentimento................. 230 


\section{INTRODUÇÃO}

\subsection{0 tema e seu contexto}

Este projeto de pesquisa se volta para a memória social dos participantes de Comunidades Eclesiais de Base (CEBs) de uma região paroquial de Santo André. A Paróquia São Geraldo Magella abrange 4 capelas. Tanto em torno das capelas quanto no entorno central da paróquia se distribuem os diversos grupos de CEBs.

No fundo, eu queria buscar memórias de pessoas que participassem de grupos com fortes valores comunitários e histórias de lutas que pudessem ajudar movimentos sociais, organizações populares e políticas a refletirem sobre alguns elementos intersubjetivos e sociais que contribuam para avançar na construção de um mundo radicalmente melhor. Quando iniciei a pesquisa, compartilhava das avaliações que consideravam nosso período como o de um certo refluxo político nos vários setores da sociedade. Ao chegar nesta etapa de conclusão do estudo, talvez já seja possível avaliar o momento sociopolítico de outra maneira. De qualquer forma, tal avaliação de refluxo foi uma motivação a mais a fim de buscar as sementes das possibilidades futuras em grupos referenciais, tais como as CEBs. Evidentemente, há outros grupos com referências humanas igualmente valiosas. No decorrer das pesquisas, fui constatando que o desenvolvimento das CEBs não poderia ser separado de grupos como a Juventude Operária Católica (JOC), a Ação Católica Operária (ACO), as Associações das Donas de Casa (ADCs), a Pastoral Operária (PO), a Irmandade do Servo Sofredor (ISSO), partidos políticos - especialmente o Partido dos Trabalhadores (PT) -, entre outros. Por isso, o todo social do qual as pessoas participam foi se revelando cada vez mais significativo.

As CEBs eram grandes referências para mim e para os companheiros que também participavam da militância católica. E na região em que moro os movimentos católicos foram extremamente atuantes desde a década de 60, e principalmente entre as décadas de 70 e 80 . $\mathrm{Eu}$ ignorava quase tudo sobre esse lastro nos bairros da região. Na região paroquial estudada, a menos de 2 quilômetros de onde moro, havia uma história de participação politizada que eu suspeitava muito esparsamente e que se revelou exemplar.

Lá foi explícita a comunidade de destino. Pela afinidade quanto ao tipo de relação entre fé e vida, oração e luta, pude encontrar não apenas sujeitos de uma pesquisa, mas companheiros e amigos. Só posso me sentir gratificado e privilegiado por estar vivendo tudo isso. Mas gostaria de garantir que esse enriquecimento não ficasse restrito a mim e pudesse 
ser socializado com outros. E considero meu dever dar um retorno às comunidades e movimentos afins. Aliás, a própria convivência com a movimentação popular desta e de outras regiões reforçou o alvo de destino deste estudo.

Assim, o contexto universitário e científico fornece muitos elementos importantes para esses fins. Mas não pretendo que o estudo se restrinja ao meio acadêmico. A prioridade é dar uma pequena contribuição aos próprios movimentos e grupos. Afina-se com o objetivo de não apenas interpretar o mundo, mas de transformá-lo, ou seja, refletir sobre a realidade em movimento e oferecer a reflexão ao devir. Por isso, as referências utilizadas, a linguagem, o horizonte ético-político pretendem, antes de tudo, apurar cada vez mais a possibilidade de chegar ao povo atuante como parte dele mesmo e não como um material estranho à sua realidade. Eis o motivo de aproximar este estudo, em sua forma, às narrativas populares.

A fundação da Paróquia São Geraldo remete mais diretamente a 1962, quando um proprietário de terreno doou-o para que se construísse uma capela que atendesse aos moradores da região da Vila Guaraciaba e arredores. Em 1963, uma comissão de moradores fez a primeira reunião para encaminhar os preparativos das obras. Detalhe que pode ser uma feliz coincidência: esta primeira reunião se deu no dia $1^{\circ}$ de maio de 1963 , o Dia do Trabalhador. E quanto estas famílias de trabalhadores seriam importantes - e já estavam sendo - para dar feição politizada à região!

Os moradores se organizaram a partir de então e iam construindo a capela com suas próprias mãos. A rotina era cansativa já que, para as obras, usavam os poucos tempos livres que tinham. Durante a semana, o tempo era ocupado nas firmas em que trabalhavam, geralmente como operários fabris, e nos finais de semana e feriados dedicavam-se para erguerem a capela que, desde a construção, já era preconizada como uma futura paróquia, como de fato se tornou. Ainda hoje há lembranças da exaustão que lhe pesava. Por fim, a capela foi inaugurada em junho de 1964 tendo como padroeiros, inicialmente, São Geraldo e São Pedro.

Entre os grupos que se formaram desde então, a Ação Católica Operária e a Associação das Donas de Casa estavam entre os primeiros ${ }^{1}$. Um dos padres franceses da Congregação dos Filhos da Caridade, Roberto du Lattay, após viver alguns anos no bairro de Santa Terezinha, em 1971 passa a atender a Capela São Geraldo, indo morar na Vila

\footnotetext{
${ }^{1}$ A localização temporal das primeiras participações tanto na ACO quanto na ADC, neste caso, remete à década de 1960. Com relação à ADC, entre os materiais de mulheres da região há a carteirinha de uma moradora registrada na Associação em 1967 e que consta em livro de Ademir Medici (1992). Quanto à ACO, baseando-se em depoimentos de ex-participantes, cruzados com materiais do Museu de Santo André Dr. Octaviano Gaiarsa e de arquivos pessoais, há indicações de que alguns moradores da região da atual Paróquia São Geraldo tenham começado na ACO ainda antes das primeiras participações na ADC.
} 
Guaraciaba, que ganha um padre fixo e no mesmo ano vê sua capela ser elevada a paróquia. Animados pelo carisma de se entregar em favor dos trabalhadores e marginalizados, os padres desta congregação atuavam como padres-operários, chegando a trabalhar em indústrias da Grande São Paulo. Assim, tinham uma forte sensibilidade para as questões que envolviam as famílias operárias.

Seguem-se as formações de outros grupos, entre os quais a Juventude Operária Católica. As pessoas que se reuniam nas casas, mesmo antes de se denominarem explicitamente como Comunidades Eclesiais de Base, já atuavam nesta direção. Em 1980, o padre José Mahon se transfere das paróquias São Filipe e São Paulo Apóstolo, em Mauá, para a Paróquia São Geraldo. Vindos da França em 1961, padre José Mahon e padre Pedro Jordanne foram os dois primeiros Filhos da Caridade a viverem no Brasil. Com a chegada do padre Mahon na São Geraldo, os grupos de CEBs foram fortemente estimulados, já se denominando explicitamente como tal' ${ }^{2}$.

A Paróquia e suas comunidades situam-se na região Leste de Santo André, abrangendo locais de urbanização heterogênea, tendo pontos de situação bastante precária convivendo com áreas em condições mais satisfatórias.

Ao percorrer a região paroquial da São Geraldo, passa-se do barro ao cimento, das casas às matas, do sotaque nordestino ao mineiro, do paranaense ao "erre" caipira paulista. Mas uma constante são as ladeiras. Escadas, escadas, escadas, ladeiras, ladeiras, ladeiras. Alguns pedaços são tão íngremes que numa mesma casa os vários cômodos se situam em patamares distintos. A sala em cima, com a cozinha alguns degraus abaixo e daí descendo. Muitas moradias nas ladeiras comportam várias gerações da mesma família, cada qual num dos andares.

Em outros pontos, casas com trepadeiras cobrindo o muro, flores na calçada, janelas convidativas. Alguns quintais com árvores frutíferas, hortas, uma pequena oficina. Se entramos nas casas, podemos encontrar retratos da família sobre a TV, sofás cobertos com tecido elástico, uma panela de pressão chiando cheiro de feijão, o calor de um forno assando pão, pequenos altares religiosos, e, eventualmente, sinais do barranco dentro das casas, que faz acumular insistentemente umidade no teto e nas paredes. E quase sempre muitas escadas.

Também há favelas. E sempre um pedaço remexido de terra e cimento, com os homens construindo uma nova casa, arrumando a que já existe, cavando uma fossa. E entre os

\footnotetext{
${ }^{2}$ As fontes deste brevíssimo esboço histórico são, principalmente, os documentos e textos do Livro de Tombo da Paróquia São Geraldo, arquivos pessoais dos moradores da época, acervos do Museu de Santo André Dr. Octaviano Gaiarsa e do Movimento de Trabalhadores Cristãos, depoimentos de moradores e de padres.
} 
barracos e casas, estão as crianças, as mulheres, alguém saindo para trabalhar na fábrica próxima, outro chegando de uma empreitada. E vistas surpreendentes, com matas densas, um lago, o antigo Parque Guaraciaba.

Sobre as casas, no meio da tarde, às vezes um acolchoado de cerração desce. Tudo parece unificado pela fumaça que cobre o dia. E, em alguns locais da região, muito altos, vêse a cidade de cima. Lá embaixo, longe, se espalham prédios feito miniaturas de brinquedo. Lá é o Centro de Santo André. Aqui em cima, o morro. É comum as pessoas dizerem quando vão para o Centro: "Vou pagar uma conta lá em Santo André”, ou “À tarde preciso ir pegar um documento em Santo André”. É como se fosse outra cidade. E, no fundo, pode haver aí uma percepção crítica muito eloquente: não seria mesmo outra cidade?

A ocupação do espaço encarnou as vidas e as lutas das pessoas que vêm constituindo a história dessa região. Ao enfrentar as adversidades de ocupar a periferia, os moradores passaram a organizar suas formas de solidariedade, seus vínculos e atuações sociopolíticas.

Suas memórias podem revelar relações com o todo social do qual fazem parte. E podem mostrar as singularidades das iniciativas individuais, os sentidos de uma religiosidade politizada, as marcas que o mundo deixa nas pessoas e as marcas destas no mundo.

Aqui não se pretende chegar a interpretações inequívocas sobre os narradores e suas narrativas. A proposta é a de dialogar com eles, construir junto com eles e com outros companheiros do campo teórico algumas reflexões pertinentes aos propósitos psicossociais, em perspectiva transdisciplinar.

As reflexões deverão ser realizadas, tanto quanto possível, na forma narrativa ou em suas aproximações. Para compor junto com os narradores as histórias e as reflexões de suas vidas, junto-me a eles também na forma. Portanto, se não em todo o trabalho e nem de modo completamente contínuo, essa escrita tentará ser uma narrativa reflexiva sobre as narrativas. 


\subsection{Objetivos}

As reflexões sobre as histórias de vida narradas por participantes de CEBs, nesta pesquisa, propõem-se olhar a articulação das elaborações de memória com a totalidade do mundo social do qual participam os sujeitos, levando em conta a possível inserção de marcas deste mundo social na própria subjetividade que o vivencia. Esta mediação entre o mundo social e a singularidade do sujeito que o vive deverá ser visualizada, principalmente, na própria narrativa memorial, mas também em observações da realidade da qual participam.

Para dar a devida atenção à relação dialética entre mundo social e subjetividade, será considerado o movimento de condições e circunstâncias vividas e modificadas pelas pessoas no percurso de suas vidas, buscando, nestas narrativas, as marcas ligadas ao contexto geográfico, às formas de trabalho, às condições de vida, aos modos de convivência, às relações com a fé, à situação social, ao contexto sócio-histórico e às adesões políticas na trajetória dos sujeitos. 


\section{ORIENTAÇÕES DO ESTUDO - COMPANHEIROS TEÓRICOS}

A filosofia de pesquisa que conduz os esforços aqui é a dialética. Assim, parte-se da noção de que todos os aspectos da realidade estão interconectados, dependendo uns dos outros reciprocamente, nas mais diversas formas de relação e num movimento de devir (cf. GOLDMANN, 1970; KONDER, 1987; KOSIK, 1976). Se o eixo é a memória, ela mesma pode ser entendida como uma totalidade relativa, pois se refere a uma totalidade que a abarca, ou seja, a vida social dos indivíduos que lembram. Busca-se, tanto na totalidade da memória quanto na totalidade da vida social, as partes em recíproca interação, da mesma maneira que o sentido de cada uma das partes só é possível buscando a compreensão de um todo. Ou seja, dá-se atenção para a dinâmica das múltiplas determinações que compõem as narrativas e, ao mesmo tempo, para o campo de sentido estruturado do qual emergem (cf. KOSIK, 1976). Cada um dos blocos temáticos das memórias pode ser uma unidade de sentido. Mas, também, podem ser entendidos como articulação dinâmica de lembranças que enriquecem a compreensão do todo, seja este todo a história de vida, ou, mais ainda, a vida social vivida pelo indivíduo que lembra.

Quem narra suas memórias é sujeito no mundo. Ao narrar, pode se pegar lançando um olhar sobre si mesmo que elabore uma compreensão sobre suas muitas relações, criando e sendo criado pelas circunstâncias que contribui para mover. Ajuda-nos a reflexão de Lucien Goldmann (1970, p.73) acerca da relação dialética do homem no mundo: “O homem é um ser vivo consciente, situado no mundo ambiente de realidades econômicas, sociais e políticas, intelectuais, religiosas etc. Sofre a ação global desse mundo e, por sua vez, reage sobre ele”. Quem narra pode, então, ver a si mesmo também como objeto do próprio conhecimento quando se percebe sujeito no meio de tantas relações. E se as narrativas aqui construídas são geradas no momento do lembrar, vale mover a atenção para as cores - tanto individuais quanto sociais - que compõem o quadro memorial. Mais uma vez, Goldmann (1970, p. 106) ajuda a refletir quando nos fala das criações humanas:

Tôda manifestação é obra de seu autor individual e exprime seu pensamento e sua maneira de sentir; essas maneiras de pensar e de sentir não são porém entidades independentes em relação às ações e aos comportamentos dos homens. Só existem e só podem ser compreendidas em suas relações interindividuais que lhes conferem todo conteúdo e tôda riqueza. 
Afinada com a dialética, a abordagem psicológica que ajudará a olhar os fenômenos será a teoria da Gestalt, dando atenção à consideração do contexto das situações, do ambiente e do sentido das experiências e acontecimentos para as pessoas que os vivenciam e narram de acordo com o significado que possuem no todo de suas vidas (cf. ASCH, 1977).

Também é preciso trazer Maurice Halbwachs (2004) para compartilhar suas considerações neste estudo. Especialmente quanto à noção de memória compreendida como elaboração e reconstrução e não como um suposto transplante dos fatos do passado ao presente. Outra presença imprescindível para as trilhas deste estudo é Ecléa Bosi. Se é preciso dar atenção para o fato de que a narrativa memorial será construída levando-se em conta campos de significação que dão sentido e totalidade à trajetória da pessoa que narra, ela mostra um percurso possível em seu Memória e sociedade: lembranças de velhos (BOSI, 1994). Lá, no meio das recordações, está escondido sentido...

Nas diversas dimensões que a memória desvela, seus aspectos sociais, ao serem levados em conta, podem ter na localização de classe, na profissão, no grupo familiar, na ligação afetiva com espaços físicos, nas relações com o tempo e no trabalho, componentes que ajudam a entender o ponto de vista de quem narra e seu processo de construção das memórias (BOSI, 1994, 2003).

Halbwachs observa que o exercício da memória individual se apóia em referenciais coletivos. Por isso, conhecer os quadros sociais nos quais as memórias se alicerçam e entender as experiências dos narradores com os grupos sociais do passado e do presente são algumas das principais orientações advindas das leituras de Halbwachs - e também de Bosi.

Mas tudo isso, embora o pesquisador possa carregar de saída em sua bagagem - e no roteiro que elabora -, precisa ser colocado na soleira da porta quando vai se encontrar com as pessoas. Ao menos, tanto quanto isso for possível. Então, ele entra na casa de cada memorialista com a simples veste da atenção. O olhar se despoja, o pesquisador já não quer seccionar, classificar, mas apenas ouvir. Solta os ombros, respira na mesma melodia do memorialista. Podem agora conversar. A bagagem que deixara na porta voltará mais à frente, numa etapa posterior, no momento da interpretação. Durante a colheita das memórias, neste trabalho de cultivar as narrativas entre pesquisador e memorialista, vale a atenção tal como o desejo de sair de si, liberdade em relação ao objeto. Assim nos revela Simone Weil (1996, 453-458), e assim retoma e indica Ecléa Bosi (2003, p. 209-219).

Quando retomo a bagagem que deixava na soleira sempre que me encontrava com as pessoas, pego-a e abro. Continuam a sair daí orientações e companheiros de reflexão. Como 
por exemplo Celso Pereira de Sá (2007), que define o campo de pesquisa da memória social na perspectiva psicossocial. Para ele, a memória social como fenômeno psicossocial é marcada pelo interesse da "memória na sociedade". A consideração de que quem lembra é o indivíduo - levando em conta que a memória é tributária da cultura, da sociedade e da história - e de que a Psicologia Social se ocupa das circunstâncias nas quais as memórias são construídas, contribui para demarcar uma abordagem no amplo campo de estudos da memória.

Quanto às diversas reflexões envolvendo a relação entre indivíduo e sociedade, algumas presenças orientam este estudo, especialmente aquelas afinadas com a dialética marxista. Além do próprio Karl Max - e Friedrich Engels - em suas obras de forte caráter humanista e com muitas reflexões pertinentes ao estudo psicossocial (ENGELS; MARX, 2008; MARX, 2010), também trazem valorosas contribuições Georg Lukács (2003), e suas reflexões sobre consciência de classe; István Mészáros (2006, 2008, 2009), com suas colocações sobre indivíduo isolado e indivíduo social, sobre as bases da consciência e sobre as perspectivas humanas de superação totalizante da alienação; e Agnes Heller (1986, 2008), com sua noção sobre as necessidades que indivíduos carregam e que clamam pelas transformações totalizantes - as necessidades radicais -, e com sua encorajadora avaliação acerca da permanência de valores ao longo da história humana. Assim como outros orientadores que acompanham este estudo, estes nem sempre serão citados nominalmente, mas certamente são grandes inspiradores de reflexões e de caminhos a seguir.

$\mathrm{O}$ aspecto religioso pode ser apoiado sobre a fenomenologia da experiência religiosa sistematizada por Miguel Mahfoud (1996), na qual a consideração da religiosidade em sua própria dinâmica aponta um caminho bastante respeitoso em relação ao tema. Ele atenta para a necessidade de reconstrução do significado da experiência religiosa, por parte das pessoas que a vivenciam, tendo a memória como via privilegiada para tal. Ainda no campo da experiência religiosa, Mauro Amatuzzi (1999) oferece uma abordagem da relação entre religião e sentido de vida, dando especial valor à simbolização da experiência e aos atos concretos que re-ligam o significado totalizante da realidade e a conexão de todas as coisas.

Quanto à relação entre religiosidade e a atuação social e política, Otto Maduro (1981) é uma das referências a considerar. Para ele, as cosmovisões das sociedades são parcialmente condicionadas pelas relações sociais dos grupos em que estão presentes, mas também condicionam a ação sobre as mesmas relações sociais, numa dinâmica dialética. Assim, o aspecto de trabalho intelectual da religião pode ter caráter emancipatório quando oferece representações de mundo numa direção sintonizada com a autonomia das classes subalternas. 
Ainda articulando religião e engajamento, Heloisa de Souza Martins (1994) traz uma análise voltada mais especificamente para a realidade do ABC paulista. Seu resgate dos movimentos católicos, especialmente em Santo André, entre as décadas de 50 e 70 , e a interpretação dela acerca dos impactos destes grupos no desenvolvimento do movimento operário, é de grande valia.

Neste estudo haverá muita menção ao "povo". Por isso, tomo parte na definição de Enrique Dussel sobre esse conceito. Sistematizando algumas das ideias sobre a concepção de povo, ele escolhe para suas reflexões o sentido estrito que se refere ao bloco social/comunitário dos oprimidos de uma nação. Exclui do conceito as classes dominantes e incorpora as classes dominadas, tanto em termos de relações prático-produtivas (classe operário-industrial, camponeses), quanto ampliando-se para grupos que exercem práticas de classe esporadicamente (marginais, etnias, tribos etc.). Para Dussel, o conceito de povo é mais concreto e sintético, enquanto o de classe mais abstrato e analítico. Ambos necessários. (DUSSEL, 1986). Dentro do bloco que constitui o povo, podem ser inclusos diversos estratos sociais oprimidos além daqueles com componentes classistas. São, portanto, parte do povo, “jovens (ante as burocracias velhas), crianças (ante a dominação pedagógica), mulheres (na dominação machista), idosos (quando já não puderem realizar trabalho produtivo)" (DUSSEL, 1997, p. 223), entre outros. Tendo em conta estes elementos de definição, parece adequado utilizar essa concepção de povo, especialmente devido à sua pertinência em relação à realidade latino-americana, na qual estamos inseridos.

E se tratamos aqui de memórias que têm em comum serem narradas por participantes de Comunidades Eclesiais de Base, sendo este um eixo forte e primordial de sentido nas narrativas - embora não o único -, é bem vinda a contribuição de Faustino Teixeira (1988), que faz uma sistematização densa da gênese das CEBs no Brasil. Há muitos outros autores que definem, caracterizam e refletem sobre as CEBs de modo profundo e profícuo. Clodovis Boff e Leonardo Boff são especialmente caros a este estudo. Com Faustino Teixeira (1988, p. 12) gostaria de compartilhar a noção de que as CEBs "não são um ponto de chegada, mas estão em criação e recriação permanente, tratando de superar suas limitações, descobrindo trilhas inesperadas". Ter em mente o olhar sobre o movimento da dinâmica das CEBs, mas também de qualquer outro fenômeno ou estrutura, é diretriz para o desenvolvimento das reflexões que serão tecidas.

Neste estudo, sempre que aparecerem citações bíblicas, a edição utilizada foi a da Bíblia de Jerusalém (2004). 
Pela proximidade de temas e abordagens com o que proponho aqui, duas dissertações do Instituto de Psicologia da USP podem ser destacadas. Uma é a de Guilherme Pogibin (2009) sobre as memórias dos operários do ABC que vivenciaram as greves de 1978 a 1980; a outra é de Karen Ribeiro (2003), que trata das lembranças que as pessoas de uma comunidade de base de Osasco evocam, tendo como eixo a convivência que tiveram com padres operários.

A opção da escrita deste trabalho que busque tanto quanto possível uma aproximação com a linguagem narrativa se apóia no referencial primordial do trabalho feito por Ecléa Bosi em Memória e sociedade: lembranças de velhos. Esta é a matriz da qual decorreram muitos dos outros trabalhos também considerados como referências aqui.

Em suma, seguindo a direção trilhada por Bosi em sua obra sobre memória, este estudo pretende acolher as vidas das pessoas, tecer reflexões e devolver narrativamente a substância memorial que me confiaram.

Finalmente, os diversos textos produzidos pelos autores da Teologia da Libertação permitem reflexões dentro da própria constelação de ideias, concepções, conceitos, significados e horizontes presentes nas narrativas e ligados às comunidades e grupos aos quais este estudo se destina prioritariamente.

Outras referências serão convocadas ao longo deste percurso conforme sugiram as narrativas. 


\section{CONSIDERAÇÕES METODOLÓGICAS}

Os sujeitos desta pesquisa são pessoas que participaram do início e da consolidação das CEBs na região da Paróquia São Geraldo Magella, em Santo André. A participação destas pessoas se desenvolve principalmente a partir do final dos anos 70 e início dos 80 , quando as comunidades dos bairros desta região paroquial se organizam cada vez mais consistentemente, relacionando atividades religiosas com atividades políticas e formas concretas de solidariedade comunitária entre vizinhos.

As pessoas foram convidadas numa conjunção de: indicações locais, participação nas CEBs no período de formação e consolidação, e disponibilidade. São 3 mulheres (Madalena, Margarida e Messias) e 1 homem (João). Devo dizer que fomos nos conhecendo aos poucos e hoje somos amigos. Trata-se de colheita de memórias. Colheita porque tudo se deu num trabalho de cultivo entre pesquisador e sujeitos da pesquisa. Cultivo também da amizade. Dos primeiros encontros para cá, já compartilhamos muitos momentos. Hoje, compartilhamos também projetos.

Para realizar a pesquisa, foram usadas entrevistas com roteiro semiestruturado. Assim, pude propor tópicos a partir dos quais os sujeitos, com bastante liberdade, formaram suas narrativas memoriais. $\mathrm{O}$ roteiro foi aperfeiçoado a partir de um roteiro-piloto.

Uma das dificuldades da pesquisa foi explicar seu caráter. Aflito, fui percebendo que as pessoas ainda não tinham ideia muito clara do que seria feito das nossas conversas, em parte por dificuldade pessoal de explicar claramente e em parte pela baixa familiaridade que este tipo de pesquisa possa ter para elas. Provavelmente, se fosse uma pesquisa historiográfica sobre as CEBs, ou um trabalho teológico sobre este tema, seria algo mais próximo do universo de referências conhecido. Confesso que eu mesmo, possivelmente, me sentiria surpreso com a proposta de uma pesquisa de Psicologia Social caso me propusessem a participação neste contexto. Mesmo assim, me parece que as pessoas notaram uma luz nos destinos do projeto. E, ao longo de nossa convivência, fui me esforçando mais ainda para esclarecer o caráter da pesquisa. À medida que apareceram as materializações do trabalho, com as transcrições, os exemplos de reflexões suscitadas pelas narrativas, tudo foi ficando mais claro. Tenho a impressão de que todos eles já têm uma boa ideia das bases desta pesquisa. Mesmo assim, somente a devolução do estudo pronto poderá avançar ainda mais nesta clarificação.

Minha convivência nas comunidades da Paróquia São Geraldo se iniciou em torno de conversas amplas, abertas às múltiplas ramificações de interesse das pessoas que evocavam. 
Às vezes em particular, às vezes em grupos, íamos percorrendo a vida, as participações, as mudanças, as reflexões que emergiam de suas falas - e gestos. Dessa maneira, pude formar uma ideia do que se adensava como mais significativo na trajetória das pessoas. Era uma maneira de elaborarmos um roteiro de entrevista em parceria. Embora não colocado dessa forma explicitamente, eu realmente pretendia que, futuramente, as gravações das narrativas memoriais fossem guiadas também, de alguma maneira, pelo que era importante para as pessoas das comunidades a partir dos indícios destas conversas.

Nesse sentido, os tópicos do roteiro foram elaborados a partir de observações prévias dos contextos em que as pessoas vivem e viveram, conversas, pré-entrevistas, estudos exploratórios com documentos diversos e convivência com os participantes de CEBs e outros grupos afins - não apenas as 4 pessoas com suas memórias registradas e publicadas aqui - em espaços de atuações e encontros variados ${ }^{3}$, articulando tudo isso para compor tópicos que correspondessem não só aos anseios do pesquisador, mas também ao que aparece como significativo para os sujeitos.

Inicialmente, eu pensava que as memórias deveriam se restringir à temática das CEBs. Nestas convivências prévias à elaboração do roteiro, percebi que as experiências significativas para as pessoas se estendiam para campos de significação mais amplos. E que mesmo se o objetivo fosse exclusivamente voltado às suas participações em CEBs, seria necessário levar em conta um percurso de vida muito maior, que dava sentido a quaisquer adesões e atuações. E é preciso lembrar que se trata de construir tanto quanto possível um trabalho conjunto. Assim, trabalhar com história de vida ao invés de memória temática foi se delineando como a escolha mais afinada com essa sintonia coletiva. Além do que, os grupos dos quais as pessoas participaram, as experiências vividas, as condições de vida, tudo isso considerado ao longo da vida, liga-se melhor à elaboração presente destas memórias. A cada momento de suas trajetórias, as pessoas foram articulando suas vidas e subjetividade com o todo social, dando sentido à sua participação em CEBs tanto quanto sua participação em CEBs contribui na formação de sentido de todas as demais experiências.

Já na fase de gravações, as entrevistas, algumas vezes, se estenderam por dias - ou noites. Nestes casos, podíamos retomar os temas tratados no último encontro e quase sempre a pessoa sentia necessidade de complementar as lacunas. Desde as primeiras conversas, passando pelos encontros gravados e os posteriores, sempre procurei me dedicar a anotações

\footnotetext{
${ }^{3}$ As participações nos espaços vão desde as reuniões dos Grupos de Rua até os encontros periódicos de nível diocesano, regional, estadual e interestadual. Também se estendem a diversos espaços de atuação, mesmo que indiretamente relacionados às CEBs, como pastorais, movimentos eclesiais e sociais, além de reuniões e organizações populares, em cidades do $\mathrm{ABC}$, nas quais a presença de participantes de CEBs se faz presente.
} 
densas de todos os detalhes quando voltava da casa da pessoa. Assim, poderia percorrer também a atmosfera, os gestos, as entonações, as situações e interações dos encontros quando precisasse relembrar e retornar ao contexto deles.

No início, sugeri a todos que utilizassem nomes fictícios para si e para as pessoas citadas. Com os textos de suas narrativas em mãos, alguns deles propuseram uma revisão da sugestão inicial e preferiram ter seus nomes reais. Aberta tal possibilidade, todos os narradores acabaram decidindo conservar seus nomes reais. Da mesma maneira, sentiam necessidade de manter os nomes reais de algumas pessoas citadas. Pareceu-me uma espécie de homenagem e de confiança quanto à aceitação da exposição dos nomes reais, no caso de pessoas íntimas aos narradores. No caso de figuras públicas amplamente conhecidas, desde que os narradores se sentissem à vontade, os nomes reais também foram mantidos. Frutos de nossa reflexão, concordamos todos com esses encaminhamentos. As pessoas citadas que tiverem seus nomes reais mantidos, por serem em menor quantidade, serão marcadas com o sinal (*), e somente na primeira vez que aparecerem em cada narrativa. Presume-se, então, que a mesma pessoa conservará seu nome real todas as vezes, daí por diante, naquela narrativa específica. Todas as demais, sem tal marcação, correspondem a pessoas com seus nomes reais substituídos por fictícios. Eventualmente, também foram omitidos locais para evitar identificações. Neste caso, segue a marcação “(local)”. Mais uma vez, prevaleceu uma concepção de pesquisa em que a participação das pessoas pesquisadas se colocou também na perspectiva de sujeitos do conhecimento, concretizada em suas narrativas, suas propostas e no compartilhamento de decisões, como no caso dos nomes reais e fictícios. Se há desvantagens ou contradições referentes a este tipo de encaminhamento, deixo aberto ao julgamento dos leitores, mas acho que a relação que estabelecemos uns com os outros não poderia ser de outra maneira sem ferir fortemente nosso companheirismo cultivado.

O árduo trabalho de transcrição foi seguido pela procura das melhores mediações para fazer jus à narrativa presencial. Assim, procurando manter tanto quanto possível o frescor das narrativas orais, tive que buscar meios de expressar na linguagem escrita aquilo que se pronunciava nas falas das pessoas enquanto narravam. Por isso, nem sempre as pontuações seguem a norma gramatical. Também fiz uso de onomatopéias, palavras em CAIXA ALTA para traduzir a ênfase e/ou exaltação do momento - e indicações de risos. Numa das narrativas mantive trechos de participações minhas e do marido (Roberto) da narradora (Messias) na conversa, pois de outro modo tais momentos ficariam esvaziados de sentido. Também devo acrescentar que, pelo menos nas narrativas, a sigla "CEBs" sempre aparecerá no plural, mesmo quando precedida de artigos no singular. Assim, eventualmente se lerá "foi 
uma CEBs", ou construções próximas disso. Dizer apenas "CEB”, numa conversa, soaria estranho e com tom de preciosismo. Eu mesmo me incluo entre os que sempre falam "CEBs" no plural. Por isso, preferi manter o frescor da oralidade também nessa situação e peço essa espécie de licença poética aos leitores.

Parte das orientações sobre como lidar com textos orais transcritos obtive nos livros de Paul Thompson (1992), José Sebe Bom Meihy (1996) e Dino Preti ([Org.], 2003), cada qual com alguns elementos de contribuição. Após ter os textos em sua primeira versão, levei para os memorialistas, que os revisaram, fazendo, por vezes, correções, subtrações e acréscimos.

Quanto às siglas utilizadas, algumas delas se referem a grupos restritos e os narradores que as mencionaram não se lembram exatamente de seu significado. Nestes casos, elas não estão indicadas na seção específica.

Nesta pesquisa, é preciso levar em consideração as colocações de José Bleger (1980) quanto às entrevistas. Segundo ele, o pesquisador também faz parte do campo e, portanto, condiciona em certa medida o fenômeno que pesquisa. Nessa linha, vale lembrar suas observações sobre a importância da relação entre pesquisador e sujeitos pesquisados, sobretudo na atenção à interdependência das condutas e sentimentos de ambos, incidindo um sobre o outro.

Sobre as relações com as pessoas que participam deste estudo, incluindo os 4 narradores e tantos outros que aqui ecoam suas vidas, devo me referir à concepção de comunidade de destino. Ecleá Bosi (1994, p. 38, grifo da autora) a partir de Jacques Loew, reflete sobre:

Comunidade de destino já exclui, pela sua própria enunciação, as visitas ocasionais ou estágios temporários no locus da pesquisa. Significa sofrer de maneira irreversível, sem possibilidade de retorno à antiga condição, o destino dos sujeitos observados.

A compreensão sedimentada no trabalho comum. Trabalho ombro a ombro. Afeto e partilha de condições de vida. Entrelace de raízes, comungando a mesma seiva, brotando ramos em direção à mesma claridade. Nossa convivência tem sido marcada pela amizade que fertiliza projetos. A busca de uma relação com a transcendência, a tentativa da coerência de vida com Jesus dos pobres, a sensibilidade em relação ao contraste entre as condições da sociedade e a imagem utópica que perseguimos. Creio que esse campo de experiências que vão se nutrindo mutuamente, assentando as vidas num mesmo solo, fazendo das pessoas 
companheiros de uma caminhada que tem ponto de partida mas que se alonga por um horizonte a perder de vista, é a base das relações entre as pessoas das comunidades da Paróquia São Geraldo e é também a base das relações que se dão entre estas pessoas e eu. Há algo que nos antecede na ligação entre pesquisador e pesquisados. Em algum momento nossas seivas se uniram. Somos companheiros de jornada, partícipes das mesmas condições condições que assumimos por necessidade, mas também por motivação moral, religiosa, política -, enfim, comunidade de destino. É na profundidade deste tipo de convivência que a pesquisa foi e tem sido desenvolvida, quem sabe para mais tanto adiante.

Por fim, e levando em conta também o significado metodológico disto, orgulho-me de dizer sobre as pessoas presentes neste estudo: meus amigos. 


\section{NARRATIVAS}

\subsection{Madalena}

Nasci dia 29/08/60, no Paraná, numa cidade que chama Peabiru. Fica na comarca de Campo Mourão. Bem próximo de Campo Mourão. Bem uns dez, quinze minutos de Peabiru até Campo Mourão. A gente vivia na roça. Morava numa fazenda que chamava Eldorado. Depois a gente mudou para uma outra fazenda que se chamava Neiva. E daí, quando eu tinha 8 ... de 8 pra 9 anos... 9 anos eu mudei para a cidade. Uma cidade que chamava Fênix. É onde meu pai mora até hoje. Daí, lá o meu pai trabalhava na prefeitura. Ele trabalhava com trator de esteira, estava abrindo a cidade, abria estradas para formar a cidade.

A gente catava algodão quando eu morava na roça, limpava debaixo dos pés de café. $\mathrm{E}$ estudava. Porque meu pai sempre quis que a gente estudasse. Então, a gente foi para Fênix, e com 11 anos fui trabalhar na casa de família. Na casa da avó desse menino que eu tenho a guarda. Ela era professora. E eu ficava lá, estudava e trabalhava. E depois eu vim pra Santo André com 18 anos. Conheci dona Margarida* aqui. Foi em 78. Julho de 78.

Lá em Fênix não tinha muita coisa. Era trabalhar em casa de família, roça ou ser funcionário público. E todo mundo que não mora em São Paulo tem sonho de vir pra São Paulo. Nossa, era o maior sonho vir morar em São Paulo. Daí, nós viemos. Também aconteceu um fato assim, que meu pai lidava com carro da prefeitura. Daí ele... aconteceu um acidente. Daí, nesse acidente, morreram três pessoas. Então, ele ficou desgostoso de ficar lá. Acabou que viemos todos pra São Paulo. Primeiro vieram meus dois irmãos, depois viemos eu e minha irmã, a Dirce*, e daí, no final do ano, veio a minha família toda. A gente veio morar lá na Gregório de Matos. Ali perto do Jardim Carla, no Maracanã. Fomos morar lá.

Não tinha nada. Tinha água na torneira, mas era muito pouco. Ninguém tinha caixa d'água. Também, a água quase não vinha. Não tinha ônibus, o ônibus vinha só até ali embaixo. Não tinha asfalto. Não tinha nada. Mas logo foi se construindo tudo. Logo que a gente chegou. Tinha um povo muito batalhador, né, assim, que fazia muita passeata, muito abaixo-assinado, faziam muitos mutirões. E daí foi indo. Foi uma época que, assim, acho que todo mundo resolveu vir pra São Paulo e ficar ali, assim, um povo que queria realmente lutar mesmo.

Nós moramos ali, depois eu mudei para a rua aqui atrás da igreja, que é Antônio Correia. Antônio Correia. E daí eu fui pro convento. Fiquei no convento uns quatro, cinco anos. Daí eu saí e fui pro Mato Grosso morar junto com... continuar morando com essa mulher, com a mesma mulher que eu trabalhava no Paraná. Trabalhei no Paraná, na casa dela, 9 anos. Daí eu vim embora, depois eu fui pro Mato Grosso. Lá eu fiquei 2 anos e meio. Daí, voltei pra cá, pra Santo André. E estou aqui até hoje. Sempre caminhando assim, lutando.

A gente tinha trabalho grande assim... construir algum coisa. Foi quando a gente começou a lutar pela creche, pelo Parque Guaraciaba... já tinha um pessoal trabalhando. Mas a gente chegou... cheguei já fui ingressando junto.

Eu sempre participei da Igreja, a vida inteira. Lá no Paraná, como eu era pequena, eu participava só mesmo da catequese. Depois eu entrei no grupo de jovem, participei de um programa lá que se chamava TLC, não sei se eu falei. Eram encontros de jovens - a

\footnotetext{
* As pessoas citadas e marcadas com este sinal correspondem a seus nomes reais. A marcação de nomes reais só acontecerá na primeira vez que o nome for citado nesta narrativa. Todos os demais, sem esta marcação, tiveram seus nomes substituídos por outro, fictício. A decisão sobre a manutenção de alguns nomes reais entre os nomes fictícios foi tomada junto com a narradora.
} 
Rosângela* também participou. Era encontro, assim, de jovens e eu achava bacana, a gente se ligava muito nas missas do padre Zezinho* pra os jovens participarem. E tinha muito estudo da Bíblia. Mas era um estudo, assim, diferente... nós estudávamos... dividia por cidades. As cidades lá são todas próximas e pequenas. Então, os jovens da minha cidade estudavam uma parte de Mateus... mas a gente estudava o Evangelho de Mateus todo. Só que dividia por três, quatro cidades. Aí juntavam todas essas cidades, os jovens, para a gente fazer uma maratona. Então, eu não podia só estudar a minha parte, que eu podia saber se você ia responder a sua certa. Então acabava que a gente ia estudando o livro todo. E tinha esse envolvimento de jovens lá. E eu acho assim que... daí é que me fez tomar o gosto pela catequese, que eu sou catequista, né. Mas de CEBs, assim, eu só ia em terço com a minha mãe. Em terço no dia de santos. Às vezes em dia de Santa Luzia rezava numa casa... em junho, dia de Santo Antônio, numa casa, em outra casa... A gente ia nos terços assim. Mas entender CEBs mesmo eu vim entender aqui, depois que eu cheguei. Lá não tinha. Podia até ser que tinha, né. Mas, sabe, ali onde eu morava, não. Tinha reza nas casas, mas não era uma reza de movimento, não. Isso na cidade.

Na roça também a gente rezava bastante. Só que na cidade foi que eu comecei a participar dos jovens. Também, foi onde eu fiquei jovem, né. Eu participei dos 14 até os 17 anos.

Quando cheguei aqui, eu achava horrível. Vim de ônibus. É... na verdade, não, eu não vim de ônibus. Eu vim de trem. Porque meus dois irmãos já moravam aqui. E daí eles alugaram a casa, e depois eles foram lá. No mês de julho, o meu irmão foi lá pra me buscar. Daí, não tinha ônibus para a gente vir. Pra sair da cidade que eu morava, tinha que pegar uma balsa. Choveu muito aquele dia, mas a gente conseguiu pegar uma balsa pra atravessar, pra ir na cidade lá que chama Jandaia. Chegamos lá, não tinha ônibus. Porque ninguém marcava nada. Daí, não tinha ônibus. Daí, nós viemos de trem. De Jandaia do Sul até na Estação da Luz.

Nós fizemos uma viagem assim: uma noite inteira, um dia inteiro, em pé. De lá até aqui. Porque estava tudo lotado, não tinha lugar. Então, foi uma viagem muito cansativa. Muito cansativa.

Quando eu cheguei aqui em Santo André, nossa, eu olhava prum lado, olhava pra outro lado, tudo muito grande. Eu sempre morei em lugar pequeno. E a estação de trem ainda não era desse jeito. Lembra que tinha uma escada de madeira? Não sei se você lembra, se é do seu tempo. Então, para a gente atravessar, descia do outro lado - o trem parava do outro lado - e daí pra gente atravessar pro lado de cá e poder pegar ônibus, tinha uma escada e uma passarela de madeira.

Então, foi naquela época. Chegamos em casa, na casa da minha tia, era quase 6 horas da tarde. Já tinha mais de 24 horas que eu estava viajando. Então eu achei muito cansativo.

Mas assim, só aconteceram coisas boas. Eu cheguei lá na casa dos meus irmãos, eu dormi a noite e tudo, quando foi no outro dia que eu fui lavar roupa, não tinha sabão, não tinha nada na casa. Sabe o que é NADA? Daí eu ficava lá pensando assim: "Meu Pai, onde que é a venda? Será que tem caderneta?". Eu ficava pensando assim, porque no Paraná nós tínhamos uma venda pra comprar e tinha uma caderneta.

E depois a vizinha do lado falou: "Oi".

Eu falei: "oi".

Ela falou: "Como cê chama?".

Eu falei: "Maria Madalena".

Ela falou assim: "Posso te chamar de Maria?".

Eu falei: "Pode".

A única até hoje que só me chamou de Maria foi ela. E ela me chama de Maria até hoje. 
Ela falou assim: "E aí, tudo bem?".

Eu falei: "Tô, tô meio perdida aqui".

Ela pegou e falou assim: "Eu vou te dar um pouco de sabão pra você lavar sua roupa".

Aí eu falei: "Ah, tá".

Aí eu falei, “ah, então é igual lá, né”, eu pensei assim, “é igual, todo mundo é igual, os vizinhos aqui também são bons". Aí ela me deu um pouco de sabão e eu comecei a lavar as roupas. Daí, quando foi assim meio-dia, ela fez um prato de comida pra mim e me deu. Foi uma vizinha muito boa. Ela era mineira. E meu primeiro dia foi assim aqui em Santo André. O meu primeiro dia...

Daí eu fui convivendo. Achei que a minha vida aqui não mudou muito da de lá, em termos de trabalho, né. Cheguei aqui, a gente tinha que trabalhar. Meus irmãos... um irmão meu trabalhava na Pirelli e o outro trabalhava na Volks. Mas, assim, a gente não tinha nada. Não tinha móveis, não tinha nada na casa. E meus irmãos, um trabalhava à noite, outro trabalhava durante o dia. Então, eu comecei a trabalhar também em casa de família aqui. Falei “ai, meu Deus...”. Trabalhei. Mas eu gostava muito de trabalhar. E aí fui. Passei aqui até... fiquei 78, 79 e 80. Em 80 eu fui pro convento. Então, eu já conhecia dona Margarida nessa época. A gente já começava a caminhar com ela aí na luta, nas caminhadas.

Então, a gente ficava na calçada, na rua. Quer dizer, não tinha calçada, mas ficava na frente da casa, conversava. Nossa, foi um ponto muito importante, porque nós tínhamos uns vizinhos que moravam em frente, eles eram evangélicos. Então eles estavam quase levando a gente já para a Igreja deles. Porque eles falavam tanta coisa de Deus. E a gente ainda não tinha começado aqui. Fomos apresentados, pois tínhamos chegado do Paraná. E foi quando a dona Margarida falou que ela também morava lá, e que se a gente precisasse de alguma coisa era só procurar ela. Só que a gente não procurou. Daí, ela foi em casa, avisando que ia ter um terço na casa do irmão dela e que ela gostaria que a gente fosse no terço. Fui eu, a minha irmã e meu irmão.

A casa estava lotada só com a família, porque a mulher tinha, acho que, 12 ou 13 filhos, e alguns já eram casados. E mais nós. E mais um outro irmão da dona Margarida que tinha mais ou menos uma meia dúzia de filhos. Então estava cheia. Tinha muita gente no terço. E começamos.

Ela nos chamava para ir ajudar a tirar a terra da igreja, para a capela, para ajudar na Caridade. Chamava a gente para vir aqui ajudar qualquer coisa, né. E a gente foi indo. Às vezes caía um barraco, ela chamava para ir ajudar a carregar madeira, ajudar a organizar.

Ela tinha muito disso, de ajudar as donas de casa. Às vezes tinha umas mulheres que eram meio desinformadas das coisas, e ela, do jeito dela... Dona Margarida é a mesma pessoa hoje. Claro que hoje, com o peso da idade, mais o filho, né. Mas ela foi sempre assim de ajudar. Daí nós vimos.

Eu fico pensando que eu tinha uma vizinha, ela tinha bastante criança. Mas aquelas meninas eram cheias de piolho, sabe, as crianças. Daí, sempre a dona Margarida: "Fazer o gesto concreto, temos que fazer um gesto concreto". Daí eu falava assim: "Ah, eu vou catar os piolhos das meninas da... - esqueci o nome dela agora... - porque isso é gesto concreto, né, dona Margarida?”. E até uma das meninas era paraplégica, ela não andava, nada. Daí, a gente chegava lá, e eu gostava muito de ajudar aquela moça lá.

Todas as pessoas eu já encontrei agora, depois de muito tempo. Minha vizinha, a Mara, encontrei com ela faz pouco tempo, lá na Cooperativa do Rhodia.

Foi até ela que me conheceu: "MAS NÃO É A MARIA?!!"

Eu falei: "Pois é, eu continuo do mesmo jeito".

A mãe das meninas também encontrei um dia desses. Então, ela mudou a vida dela, ela se transformou. Era aquela mulher pacata que não fazia nada, ficava em casa com aquele 
monte de meninos, tudo sujo, tudo cheio de piolho. E hoje não. Hoje ela trabalha numa empresa. Ela é uma outra pessoa. Eu falei assim: "tá vendo a diferença que as pessoas fazem na vida do outro, né". Sempre falo: "Todo mundo deveria ter uma dona Margarida na sua vida".

A gente foi entrando nas CEBs. E daí, as CEBs era movimento mesmo. A gente se movimentava aqui. Tinha bastante reivindicação. Daí foi quando surgiu a reivindicação para as caixas d'água, que não tinha água, faltava muita água. Não tinha energia lá, daí foi quando teve uma luta grande pra conseguir a energia. E não tinha esse negocinho de político ali. Depois que veio. De uns tempos pra cá que começou a entrar alguém para ser vereador e para ajudar. Mas naquela época, não. Era o povo mesmo, era a Igreja, as CEBs que se unia e ia para conquistar as coisas.

Daí já conseguimos que o ônibus fosse até lá em cima, que não ia. Os daqui, iam até o Humaitá, mas depois chegaram no Vila Suíça.

A primeira luta que participei foi do ônibus. A mais forte que eu tive. Nossa, foi uma luta grande mesmo, do ônibus. O padre Mahon* já estava aqui. Ele ajudou muito, mas muito mesmo, pra conquistar o ônibus. E demorava demais pra passar, eles paravam cedo. Às vezes, as pessoas saíam 10 horas do trabalho, tinham que vir, às vezes, a pé de Santo André pra cá porque os ônibus já tinham parado. Era muito bagunçado. E foi uma luta grande. Passávamos a noite inteira marcando horário de ônibus. Quando fazia greve, a gente ia atrás e... olha, eu sei dizer pra você que essa foi uma das lutas bem grandes.

A gente ficava marcando os horários dos ônibus pra ver quando passava, o tanto que demorava, para a gente poder levar pra conquistar, pra conseguir. Então, hoje, às vezes eu fico vendo o pessoal no ponto, briga, reclama, né, eu falei: "Ah, vocês tinham que ver isso aqui há 20 anos atrás, há 15 anos atrás". Uma luta grande...

Os donos das empresas de ônibus faziam o que eles queriam. Do horário de 11 até umas 2 horas você podia morrer no ponto que não passava o ônibus. E eles alegavam que era horário de almoço. Então era muito difícil, muito difícil.

De manhã cedo, às vezes tinha mais gente e, de hora em hora, a gente não conseguia entrar. Acontecia muito acidente, muito acidente mesmo. As pessoas iam entrar e o ônibus saía, e ficavam pendurados na porta.

Nem sei se eu te falei da minha irmã, que ela foi arrastada dum ponto no outro. O ônibus lotado, daqueles que pegava ali. Ela foi entrar e o ônibus saiu e ela não soltou. Ficou segurando de pé, que ela já tinha pisado e escapou. Daí, ela foi arrastada de um ponto ao outro. Eu falei que nesse dia, olha, Deus se fez presente, porque o ônibus foi numa tirada só. Ele não ia parar no outro ponto. Não ia. Ele saiu e foi. E daí, quando ele estava quase chegando no outro ponto, surgiu um homem na frente do ônibus que ninguém sabe de onde que surgiu - quem estava no ônibus não sabe... E daí, o ônibus teve que parar. Foi aí que a minha irmã caiu pro lado de fora, soltou a mão, porque ela já não aguentava mais. Depois, eles queriam linchar o motorista. E fomos para a garagem, fomos para a delegacia e ela foi para o hospital. Foi uma coisa horrível.

O motorista falou que não tinha visto ela pendurada. Vai ver que não tinha mesmo. Estava muito lotado o ônibus. E uma senhora, também, foi entrar no ônibus, ele saiu, ela caiu, bateu a cabeça na guia. Tudo isso aqui, nesse pedaço.

Então, cada vez era foto, era assinatura. Porque a gente saía do serviço às cinco horas da tarde lá no Centro e ia chegar aqui em casa oito, nove horas da noite, tentando pegar um ônibus, que era muito difícil. Muito difícil para a gente vir, porque eles não passavam, e quando passava era muito lotado. Tinham poucos, não era igual hoje. Hoje até que tem. Mas eram poucos ônibus, então... 
Quando a gente anotava tudo isso, ia para a prefeitura. E lá a gente aproveitava o plenário. Quando tinha sessão, entrava todo mundo. Aí, eles tinham que ouvir a gente, porque era muita gente mesmo, sabe, muita.

Tudo saía daqui. A gente arrumava carro, ia a pé, dava um jeito. Quem estava lá no Centro trabalhando já ia de lá. E daí a gente escolhia - era tudo organizado -, uma pessoa para falar, a pessoa para reivindicar. E combinava os gritos de guerra para gritar, para falar. Sempre quem falava bastante era o seu Zé Bento*. Ele já é falecido, seu Zé Bento. Sempre lutou bastante. Ele era irmão da dona Margarida. E depois veio a dona Hosana. Você falou com a dona Hosana também, né?

Dona Hosana foi mais Amigos da Creche, das cooperativas. Ela também lutou bastante. Nossa, a melhoria pro bairro, asfaltar algumas ruas, ela também fez bastante. Essa caixa d'água que tem aqui. Tudo aqui foi conquista mesmo desse povo daqui, dessa igreja, das CEBs. Foi bom.

Eles fizeram cooperativas, e aí eles traziam os alimentos e passavam aqui para as pessoas, mais baratos, mais em conta. E, eu sei que a dona Hosana... Nesse tempo tinha a Tina, que participava já, a dona Odemira. Foi quando surgiu também a ACO, né, aqui, junto com o padre. Daí o padre Miguel* já estava por aqui também. Até que formaram aqui algumas cooperativas, para ensinar as pessoas. Mas não conseguiu muito... Mas foi uma luta bem boa, bem bonita. Isso foi quando eu estava no convento.

A luta da água, nossa!, a gente ia na prefeitura com balde, com garrafa, com tudo, água, água suja, água limpa. Porque faltava muita água. Aqui faltava, imagina lá que é muito mais alto ainda. Então eu sei que a gente lutava. Dona Messias* também participou dessa da água. Porque a água chegava só de madrugada para nós. Só de madrugada. Então, não dava tempo da caixa encher, que já cortava a água de novo. Então, a gente tinha que ficar de madrugada acordado, encher os baldes, encher tanque, encher tudo, porque daí a água já ia acabar de novo. Acabava direto. Agora não. Agora a gente nem sabe quando a água acaba.

A gente levava os baldes e a água como símbolo. Aí começávamos a bater lá, fazer a maior arruaça na Câmara. Os prefeitos dessas épocas aí eram o Brandão*, e pegamos o Grillo* também. Foi sofrido. Foi uma luta. Sofremos bastante. Eles tinham uma raiva dessa igreja, desse povo daqui, que meu Deus. Mas não era só nós. Tinha o pessoal do Jardim Alzira Franco que lutou bastante, as outras igrejas também. Mas, assim, a São Geraldo era bem ativa mesmo. Era muito ativa.

O pessoal da prefeitura não queria nem deixar a gente entrar, eles não gostavam. Mas a gente não avisava que ia, entendeu? A gente se organizava aqui, e depois, quando a gente sabia que ia ter uma sessão, daí a gente ia. Se virava. Ia a pé, ia... dava um jeito. E daí até hoje... Esses dias eu estava conversando com o médico que chegou no posto novo, e ele perguntou para mim o que tinha antigamente que eu gostava, e o que falta agora.

Eu falei: "O que é que tinha? A luta. O povo lutava. Hoje o povo não luta mais não, que eu sinto falta desse movimento de luta do povo".

Ele falou: "É verdade".

Eu falei assim: "Sabe por que doutor? Esse posto está do jeito que foi lutado pra conquistar, pra conseguir. Não mudou nada. E ainda hoje nem médico suficiente tem pra atender aqui as pessoas".

Daí ele falou: "É verdade. Falta luta do povo, está precisando".

Ah, daí foi o tempo. Mas foi melhorando. Mesmo o Brandão, depois ele foi recebendo melhor as pessoas. Mas no início, ele maltratava muito, ele não recebia muito bem. Xingava. Ele ficava, assim, um conversando com o outro enquanto a gente estava falando, enquanto 
tinha as pessoas falando lá. Ele não dava a menor importância. Demorava pra conseguir uma conquista lá.

Quem ia reunindo as pessoas aqui eram a Dona Hosana, Antônia. Um ia passando para o outro, e a gente se organizava muito aqui na igreja, naquele salãozinho pequeno que tem ali. Só tinha aquele salãozinho. A gente se organizava ali. Todo mundo vinha. E marcava reunião. O salão ficava lotado, ficava cheio.

Nos Grupos de Rua se discutia. E daí um grupo tinha uma ideia, já trazia para cá, e se dava para aproveitar, já aproveitava. Os grupos discutiam o que iam buscar de melhor, e sem esquecer também o lado religioso. Se rezava bastante. Tinha muita espiritualidade, tinha bastante também. A gente não ficava só na reza, lutava bastante. Mas tinha também muitos momentos de espiritualidade. Celebrava, né. Se celebrava muito. Ixi, quantas vezes a gente conquistava um negócio, enchia essa igreja pra rezar uma missa. E o padre Mahon era bem animado. Perto do padre Mahon tinha o padre Ivo*, o padre Bernardo* também, que ajudava bastante. Depois veio o padre Miguel que já é menos... mais reservado, mas que não proibia. Ele sempre cedia o espaço, mas não participava assim, igual o padre Mahon, não. E agora...

O padre Mahon incentivou muito. Até hoje, se precisar, ele está aí. Ah, ele participava bastante. Nos $1^{\circ}$ de Maio ele sempre celebrava aqui, depois a gente ia lá pra São Bernardo com ele. E também quando foi pra ocupar a favela. Padre Mahon esteve sempre muito presente, ajudava bastante também nessas coisas. Sempre tinha uma celebração depois. Às vezes fazia celebração no lugar. Isso também era uma marca registrada do padre Alfredinho*. O padre Alfredinho também gostava muito de fazer isso, uma celebração lá no lugar. Celebrava a vida, e ele levava os paramentos todos e a gente celebrava lá. Se não tinha hóstia, ele pegava o pão, e era muito bom. É pena que a gente nem tem tanto registro assim.

Aí ele levantava e ofertava a enxada, apresentava tudo que a gente tinha lá. E mesmo aqui, sempre quando celebrava alguma conquista, e mesmo que não tivesse dado certo naquela época, naquele dia. No tempo da água era panela, era caldeirão, a gente fazia toda aquela apresentação... da vida.

Mesmo quando não tinha dado certo a gente celebrava, e combinava já pra ir num outro dia. Sempre a gente celebrava. Tinha os momentos de luta e no final uma celebração para a gente poder agradecer a disposição das pessoas.

Era diferente, era diferente. A gente se sentia assim... eu nem sei, assim... sentia vida mesmo, né, vida e alegria de poder estar ali lutando. E tinha umas músicas muito boas que a gente cantava, animava, esses cantos mesmo de protesto que a gente cantava. Dava mais um vigor. A gente ia no outro dia trabalhar, no mesmo trabalho, do mesmo jeito, mas assim, com mais esperança. Tinha mais esperança. E eu sempre penso: se a gente não mudou, continua do mesmo jeito, foi porque ou não quis ou porque está satisfeito com a vida que tem. Mas que teve MUITA mudança, teve. MUITA conquista, muita luta. E a gente vê que as pessoas se transformaram, mudaram. Compreenderam o que é lutar por uma igualdade. Pra escapar da desigualdade, a gente lutava por uma igualdade juntos. Direito pra todos... Esse era sempre o lema: igualdade para todos.

Depois veio o Alfredinho. Não posso nem te dizer o tanto que se aprendeu com o Alfredinho. Foi uma CEBs diferente. O pobre foi resgatar a dignidade. Tem até Tetê*, que ela fala: "O pobre vai levantando a cabeça devagarinho... não é com pressa, é devagarinho". E daí começaram a surgir os Grupos de Sete da Irmandade, em que a gente não ia mais lutar para buscar comida pedindo. Mas a gente ia aprender como conseguir essa comida.

Tem uns grupos até hoje, lá na Lamartine mesmo. O Grupo do Coador. As mulheres aprenderam a fazer coador, depois vendiam, o pano de prato, o pão. Eu mesmo trabalhei muito tempo na padaria comunitária. Tinha um barracão na favela e a gente fazia lá os pães, 
com as mulheres de lá. Então, a gente ensinava elas a fazerem o pão, e daí a gente ia vender esse pão. E dividia o dinheiro pra elas, com elas lá.

Então, a gente não se reunia todos os dias, a gente ia duas vezes na semana, acho que era de quarta e sexta. E a minha irmã, nessa época, trabalhava numa empresa aqui embaixo, na Vila Luzita. Então, de quarta-feira, já era certo a gente vender 30 pães lá onde a minha irmã trabalhava. As mulheres iam lá levar, vender, receber e depois partilhar o dinheiro. A gente saía vendendo nas ruas. Aqui mesmo em Santo André. E nós fazíamos lá e depois, à tarde, depois das 3 horas a gente começava a sair pra vender, e vendia todos os pães. E as mulheres ficaram muito tempo assim. Aí elas ficaram lá, fazendo, vendendo.

E daí tinha o grupo... aprendia... A gente abriu uma casa ali na Valentim. Sempre lugares onde tinha pessoas desempregadas e precisando. Fizemos ali na Valentim um grupo de pano de prato. A gente ia sempre um domingo. Era no domingo porque era o melhor dia para as mulheres irem aprender. Ensinava, aprender a pintar, fazia os panos, a gente vendia. E daí vendia na igreja, vendia nos bairros. Foi assim.

Tem tantas mulheres que ainda pintam pano até hoje, que vivem assim. E assim foram surgindo vários outros tipos de artesanato. De pessoas que não tinham trabalho, que não tinham renda, que iam pedir cesta básica nas igrejas e que depois pararam de ir. Porque daí elas conseguiram seu sustento. Então, por isso foi uma CEBs diferente que padre Alfredinho trouxe. Um jeito novo de trabalhar, de fazer Igreja. E tudo isso dentro da espiritualidade. $\mathrm{Na}$ linha do padre Alfredinho era mais no silêncio. Então assim, mais na meditação, na contemplação, no silêncio. Era uma luta sem violência, ele falava. Uma luta sem violência. Porque quando o pessoal descobriu que ele estava na favela, começaram a levar cobertor, comida, roupa pra distribuir para os pobres. Daí ele falou que não, que não era assim, que eles iam trabalhar. Podia deixar lá, que era uma partilha, mas que não era para continuar. E muita gente ia lá do Centro para levar as coisas lá. Mas então, porque a figura do padre estava lá. E quando ele não estava? Aquelas pessoas não precisavam? Precisavam, né. E então foi mudando assim. Ele falava: "É uma luta sem violência". Muito bom mesmo, trabalhar com o Alfredinho também. Marcou muito. E ele sempre pregava assim: "Sem competição, sem violência. Sem competição, sem violência. No caminho da austeridade".

Eita! As greves eu lembro. Mas eu não participava, eu tinha medo. Mas, assim, o pessoal participava muito. Eu ia pra ajudar a fazer barulho. Ah, eu tenho um irmão que até hoje fala que ele só não trabalha na Volks até hoje por causa do Lula* (risos). Porque disse que o Lula ficava fazendo greve. Então, você vê, eu tive até oportunidade de ser amiga do presidente, né.

Então a gente ia muito, sempre ia, mas eu ficava mais de longe. Eu lembro muito do Vicentinho* nas greves, do Lula, e tinha também o... agora ele é deputado, esqueci, esqueci o nome dele agora, que também era bem ativo aqui no sindicato, nas greves. Se juntava muito aqui na praça da igreja pra poder fazer a falação para o povo. Porque os filhos do seu Zé Bento, uns trabalhavam na Volks, outros trabalhavam em tantas firmas aí. Daí ele chamava eles pra virem aqui. Para não ficar muito longe de ir, eles faziam sempre aqui. As reivindicações, fazia uma fala aqui na praça da igreja para o povo. E sempre com apoio do padre Mahon. Sempre ajudou. Padre Mahon foi preso. Não ficou muito tempo na cadeia mas ele foi preso. Acho que passou uma noite. Mas várias vezes eles pegaram o padre Mahon e levaram preso. Quando teve a ocupação do Centreville mesmo. Ele apanhou bastante naquela época, foi preso. Mas foi uma luta boa.

O Centreville, quando começaram eu estava no convento. Daí foi quando eu saí, cheguei e ainda estavam ocupando. Até a gente conseguiu uma casa lá mas não tinha quem fícasse. Uma casa para a minha família. Mas aí não tinha quem fosse morar lá. Então, a gente quis ficar. Porque tinha que ficar um bom tempo lá, dia e noite pra ninguém... pra não perder. Mas 
quando foi ter as celebrações, a gente sempre ia participar. No Vista Alegre... foram tudo ocupações que a gente participou.

Então, a gente apoiava assim: como algumas pessoas tinham que ficar lá, a gente fazia comida. Juntava bastante mulher, a gente fazia comida, levava lá, levava água, porque lá em cima não tinha nada, lá no Vista Alegre. E então tinha que levar comida, levar água, levar roupa, porque eles não podiam sair de lá. E a nossa participação foi assim. Mas aí teve o padre que dormiu lá também. O padre Alfredinho subiu, foi ficar lá. E eu lembro que a primeira celebração, a primeira missa lá foi ele que celebrou. E daí ele falou bem assim: "Que vista bonita, que vista alegre". (risos)

E começou a cantar:

"Virá o dia em que todos

vão levantar a vista

veremos nesta terra

reinar a liberdade".

E daí, foi a primeira missa. Então, a gente, nossa!, eu lembro de todo mundo chacoalhando a mão. E foi uma SATISFAÇÃO que dava na gente isso, UMA ALEGRIA, eu não sei explicar o que a gente sentia. Parece que não é mais o mesmo entusiasmo igual a gente fazia naquela época. Era muito bom mesmo. E eu tenho bastante saudade. Tudo bem que a luta hoje é outra, né. Hoje nós temos que lutar contra as drogas, contra a violência, contra outros tipos de violência, outros tipos de escravidão. Mas parece que a luta perdeu o sentido. Perdeu o sentido...

E a gente conquistou tanta coisa, tantos direitos. Tantas coisas que a gente conquistou. Deveria ter o mesmo entusiasmo, mas não tem. Talvez outros valores, outros meios de vida pra se viver, né.

Teve padres que não aceitavam. Não aqui da nossa comunidade. Mas teve padres que ficavam do lado dos poderosos. Eles ficavam do outro lado, e teve muita resistência, sim. O próprio bispo mesmo naquela época, o Dom Cláudio*, ele não era muito assim a favor. Ele era a favor mas ele não era muito liberal, assim. Ele era um bispo mais durão ali. Porque se naquela época fosse o Dom... aquele que morreu... Dom Décio*, a igreja teria participado mais, viu. Porque tinha igreja aí que não aceitava a gente falando. Não aceitava falar de política, não aceitava falar das lutas, do que estava acontecendo. Não aceitava, não. A Igreja começou a ficar meio dividida naquela época. Mas depois...

A greve de 78 foi uma greve forte. Meu irmão fazia pouco tempo que estava na Volks. Ele tinha entrado na Volks no começo do ano e já teve essa greve. Mas eu não participava ainda, não.

Aí, a de 80 eu já estava indo para o convento. Foi quando, eu acho, que o Lula foi preso. Foi nessa, acho, né? Se eu não me engano. Mas até a gente passou muita necessidade. Porque eles ficaram muito tempo em greve. Foi em 78. Ficaram vários dias em greve, daí não tinha pagamento. E a gente passava muita dificuldade, por causa da comida, a gente nem tinha em casa. Daí, o que nós fizemos? Eu e minha irmã fomos trabalhar de doméstica - foi logo que nós chegamos aqui, eu lembro disso. E assim, não só nós, mas várias pessoas estavam passando essa dificuldade por causa da greve. Então, é por isso que às vezes o meu irmão fala que a culpa é do Lula. (risos)

Eu tinha estratégia para ir nos piquetes. Inventava tanta coisa. Ia de manhãzinha e depois ia trabalhar... dava sempre uns... mas valeu a pena, não foi em vão, não.

Eu, desde lá do Paraná, sempre falava: "Eu quero ir pro convento, eu vou pro convento". Morando lá no Paraná. Daí, o padre da minha cidade, o padre Lauro*, tinha duas irmãs nessa 
congregação que eu fui. Então, ele pegou e, quando eu tinha 13 anos, me levou lá para eu conhecer a congregação lá em Petrópolis. E daí eu fui, gostei muito, fiquei deslumbrada. É a Congregação das Irmãs de Santa Catarina. Eu fiquei deslumbrada com tanta coisa bonita que eu via. Daí eu falei para a minha mãe: "Não, eu estou decidia. Eu vou, quero ir".

E daí eu vim para São Paulo. Esperei ainda mais até eu ficar com 17 anos. E eu falei para o meu pai: "Agora eu vou". Daí, foi quando meus irmão vieram para São Paulo, em janeiro de 78. E em julho eles foram me buscar, porque eles estavam morando aqui sozinhos, para ficar tomando conta da casa. Eu falei: “Ah, não. No próximo ano eu vou”. Daí foi quando aconteceu o acidente com meu pai. Daí meu pai veio embora e eu ainda fiquei aqui o resto de 78, 79 inteiro.

No começo de $80 \ldots$ começo de 80 não, um pouquinho depois de 80 , eu fui para o convento. Foi muito interessante. Eu tinha assim, não sei... até hoje eu nem sei, realmente, qual é a minha missão. Acho que eu já vivi a missão tanto, que eu nem consigo assim... Porque eu cheguei no convento, e quando eu tinha 13, fiquei deslumbrada, tudo chique, bonito, maravilhoso. E daí, eu fui trabalhar numa creche. Trabalhar na creche... tanta pobreza, tanta pobreza que eu não dava conta. Sabe assim? Eu achava que eu era pobre, e ali eu via a pobreza de perto. Umas crianças tão sofridas, tão sofridas. E as mães deixavam lá, só vinham de tarde buscar. Com a fralda que eles iam embora, eles voltavam no outro dia, com a mesma roupa. Chegavam tão famintos, tão famintos...

Daí, um dia, eu estava conversando com uma moça lá, e eu falei assim: "Onde você mora?".

Ela falou: "Ah, eu moro lá no morro".

Eu falei assim: "Ah, no morro é?".

"Sabe onde é o lixão?".

Eu falei: "Sei".

“Ah, então, é lá perto".

Daí um dia, nós combinamos e fomos lá ver o lixão. Quando a gente chegou lá, mas eu fiquei tão assim... as crianças que a gente tomava conta na creche, elas estavam lá catando lixo! E era um domingo. Então, quer dizer, eles não tinham comida, eles tinham que...

Vendo, a irmã falou assim: "Vocês estão vendo? Eles disputam o lixo com os urubus".

Aquilo foi me dando uma dor no coração... Tinha criança que os pais deixavam lá, esqueciam lá, não iam buscar. Daí, a gente tinha que ficar dormindo com as crianças lá na creche. Ai... eu fui ficando assim sabe... foi me dando uma tristeza, e eu ficava pensando assim: "O que é que eu estou fazendo aqui? Essas freiras não fazem nada. Só ficam na creche. Mas e agora? A gente tem que fazer alguma coisa, é impossível não ter o que fazer".

Daí, eu peguei, fiquei lá. Fiquei até 84 , ali na creche. Fui noviça, fiz os primeiros votos. Eu acabei de fazer os votos, pedi para sair. A minha irmã foi, até, nos meus votos. Daí ela ficou lá um tempo e depois veio embora.

Daí falei: "Ah, irmã, não vou ficar aqui, não. Não dou conta de ficar aqui. Eu acho que Deus me quer em outro lugar, mas não aqui. Eu tenho que lutar com o povo. Eu venho de uma comunidade onde a gente luta, onde a gente conquista as coisas para as pessoas, para o povo. E aqui a gente não faz nada. Fica só aqui, só dentro desse convento aqui, ó. Bons dentistas, bons psicólogos, bons tudo, e eu acho que está errado".

Daí ela falou assim: "Não, vai lá no sacrário, reza".

Daí, eu vim embora, pedi para sair. E depois eu fiquei sempre pensando nisso: "Como será que aquelas freiras conseguem? Porque eu não consegui. Não consegui ser freira vendo tanto sofrimento, tanta miséria". Daí eu estava conversando até com o padre Luiz e ele falou que pensa assim também. Porque não tem como. Você vai num colégio desses de freira, é uma fortuna. É uma fortuna. E assim, tudo bem que elas não vão tirar o pecado, não vão salvar a humanidade, mas a gente tem que fazer alguma coisa. Tem que fazer. 
E daí eu saí do convento, fui para o Mato Grosso, fui embora, casei, descasei. Eu tenho um filho de 19 anos. Então, e continua que... eu falei assim... não mudou muita coisa, né, continua... mas o que eu posso fazer eu faço.

A minha vizinha tem um câncer na medula. Se ela não pode lavar a roupa dela, eu lavo para ela. Quer dizer, eu não estou fazendo muita coisa, mas eu acho que eu estou fazendo. A gente ajuda alguém aqui, ajuda ali, ajuda alguém a conseguir a sua aposentadoria, explica, pelo menos, como que ela vai conseguir; se não tem.... acompanha para conseguir o remédio, para conseguir marcar consulta. Então, eu acho que, não sei... eu mudei, saí de lá e vivo assim agora. Tenho o meu trabalho, mas se eu posso orientar as pessoas a... se ela não sabe ir a primeira vez, eu ajudo ela a primeira vez, eu vou indicar o caminho, para ela conquistar. E tudo isso, eu aprendi com quem? Com o padre Alfredinho.

Daí eu vi que, realmente, a missão do leigo, do padre e da freira é a mesma. É você se colocar a serviço e servir, e pronto. Mas eu gosto muito das freiras lá de onde eu fiquei. Até há pouco tempo eu falei com uma por telefone. Voltei lá muitas vezes depois. Daí eu não voltei mais. Mas assim, só que eu não consegui ficar lá, não consegui. E eu fico sempre me perguntando: "Não consegui ser freira, não consegui ficar casada, vamos ver o que eu vou conseguir fazer agora, né". Mas acho que a minha vida é essa. Vivo assim.

Eu entrei na Irmandade. Eu sou consagrada já há mais de 10 anos na Irmandade. E renovo todo ano a minha consagração.

O padre Alfredinho não tinha vindo ainda quando eu cheguei do convento. Veio para cá em 88. O Alfredinho veio para cá 4 anos depois. É, foi 88, quatro anos depois. Ele fícou aqui... ele morreu em 2000, e viveu aqui doze anos.

Daí eu fui novamente lá para a base. Fui tudo de novo. Fui acompanhar a dona Margarida, fomos para as CEBs de novo, fui participar dos grupos, daí entrei aqui na catequese.

Lá em Petrópolis eu também era catequista. E ia também lá nos morros. A gente dava catequese lá nos morros. E depois eu continuei aqui catequista. E a gente já estava se envolvendo com as famílias. A gente ajudava nas famílias mesmo. E depois que eu fui... eu parei um pouco, voltei a trabalhar. Daí meu trabalho já era trabalho em loja, já era um trabalho mais intenso. E daí o padre Alfredinho chegou.

Nossa, e aí um impacto. Porque assim, o padre da favela, né. A gente falava bem assim: "Esse padre é doido", ficava pensando "esse padre é doido". E ele fazia celebração lá naquele barraquinho. A minha irmã, de cara, já entrou na Irmandade. Sabe? A minha irmã que mora no Ceará. Ela e mais 4 pessoas. Depois veio a Selma. A Selma morava lá em Crateús. Veio pra cá. E a gente foi se achegando, foi vendo que foi um jeito novo, um jeito diferente. Daí nós fomos participando.

Dona Margarida também foi, dona Hosana, Antônia, todo mundo, começamos a participar. Quando foi em 93... é 93 - fazia 5 anos que o padre Alfredinho estava aqui - teve uma seca muito grande no Nordeste. Então, o padre Alfredinho lançou uma campanha lá na igreja. Lá na Capela Nossa Senhora da Caridade. Para a gente fazer um jejum. Você ia fazer um jejum de alguma coisa, e aquele dinheiro você ia mandar, passar para ele, e ele ia mandar para o Nordeste. Para o pessoal lá do Nordeste, da Irmandade, fazer sopa, comprar alimento para as pessoas que estavam passando fome. Então, ele pegou e lançou isso que nem uma celebração, numa missa.

Ele pegou e falou: “Quem quer participar comigo?”. E daí, ele falou: “E hoje eu inicio um jejum de 9 dias". E dormia numa esteira de palha, e ele passou 9 dias dormindo ali, só assim no jejum mesmo. E daí, menino, mas houve uma adesão! A igreja inteira levantou a mão. 
Você sabe que esse PAF existe até hoje. Toda terça-feira - acho que eu já falei isso pra você -, às 7 horas da manhã tem a celebração do PAF lá na Caridade. Eu não vou mais. Mas tem muita gente que ainda vai. O padre Mahon mesmo é um que vai. Então, teve pessoas que deixaram de fumar e davam o dinheiro para o padre Alfredinho. Parou de fumar, nunca mais fumou. Teve pessoas que deixavam de comprar alguma coisa durante aquele mês, pro dinheiro. As crianças participavam. E pessoas que deixaram de pagar o ônibus, iam a pé trabalhar pra poder passar o dinheiro.

Eu sei que foi uma campanha LINDA, LINDA, LINDA mesmo. MARAVILHOSA. E daí, no jejum de 9 dias muita gente ficou com ele. Teve pessoas que ficaram os 9 dias, outras que ficaram 3, outras 4, assim, 1 dia. Mas foi maravilhoso. No nono dia caiu uma grande chuva no Nordeste. Uma chuva grande. E, depois, o bonito é que o povo mandava cartas falando as maravilhas que aconteciam. Daí, eles conseguiram dinheiro para fazer artesanato, para vender, fazer a sopa para alimentar as pessoas. Faziam as sopas 2 vezes por dia, de manhã e à tarde. E um belo dia eles mandaram uma carta linda dizendo que não precisavam mais. Isso é maravilhoso! Eles podiam ficar quietos. E daí então o padre Alfredinho falou: "O que é que a gente faz?". Daí, todo mundo quis contribuir.

Tem algumas pessoas daqui que contribuem. E, então, a Selma pega, recebe o dinheiro e, hoje, compra-se remédio para quem precisa, já compramos aqui cadeiras de rodas, tem pessoas que a gente mantém com a fralda, que usam fralda. Então, é muito bonito. E isso tudo foi, assim, mudando o jeito...

PAF significa 'Porta Aberta aos Famintos', por que isso começou lá em Crateús. Não sei se eu já falei, mas acho que eu já falei para você, que teve uma grande seca lá no Nordeste. Daí, o padre Alfredinho também fez esse jejum. E, na missa, ele perguntou assim para os fazendeiros, porque lá tem gente rica, né... para as pessoas de fora, as que moram na cidade, prefeito, e todo mundo, ele pegou e falou: "O pessoal do cerrado, do interior, está vindo para a cidade. Eles estão vindo com fome, e eles vão saquear as casas, e eles vão...”, e daí o padre Alfredinho falou: "Então, ao invés de acontecer isso, se vocês colocassem esse cartão nas suas portas? Então, em todas as casas que eles encontrarem esse cartão eles vão poder bater. E daí, vocês vão dar um pouquinho de alimento para eles".

Então todo mundo concordou. A gente colocou. Ele fez com a própria mão dele muitos cartões. Escreveu PAF. Depois, embaixo: 'Porta Aberta aos Famintos'. E ele foi pregando junto com o pessoal da Irmandade de lá nas portas das casas. Então, quando as pessoas vinham... ele foi orientar o povo, né. Então, a pessoa chegava na minha casa, tinha o cartão lá: 'Porta Aberta aos Famintos', eles sabiam que ali eles podiam bater e que eles iam ter comida, água fresca e isso tudo.

Então, foi muito bonito. Não teve invasão, porque já tinha tido outras vezes. O povo ficava com fome, eles invadiam as casas porque tinha, né. E daí fizeram isso. E depois ele fez isso aqui. E o pessoal daqui mandava dinheiro pro Nordeste, lá para Crateús, para alimentar o povo de lá. E agora o PAF continua, mas com o dinheiro eles compram remédios, ajuda quem tem um barraco que cai, ajuda na construção daquele barraco, se alguém tiver que comprar um gás... Quem realmente precisa. Eles ajudam com esse PAF. Muito bom. Uma ideia boa do Alfredinho. É legal.

Uma vez, vieram entrevistar ele. O povo da rua, lá de São Paulo. Eles não conheciam o padre Alfredinho. Daí, vieram. A Eleonora falou: "Ah, eu vou pedir para uma pessoa da Irmandade levar vocês lá". Ela pediu para mim. Daí, eu fui levar o pessoal lá. Eles nos filmaram caminhando lá na favela, tiraram foto. Daí, fizeram um jornal e mandaram para o padre Alfredinho.

Daí, ele disse assim: "Olha, você eu não sei, mas a primeira vez que eu saí no jornal, vou guardar". (risos)

Eu falei: “Dá um aí que eu vou guardar também”. (risos) 
Até há pouco tempo eu tinha esse jornal. Hoje, eu procurei outro dia lá em casa e não achei. No dia que ele faleceu, quando ele faleceu, saiu no jornal de novo. Daí, gravaram e puseram novamente aquela foto que estava eu e ele. Eu falei: "Ah, essa eu vou guardar".

E quando ele estava quase para morrer, ele disse assim: "Ah, eu tenho um sonho... eu tive um sonho", 4 horas da manhã. Então, a gente dormia lá com ele, junto com ele e a Selma, se precisasse acordar à noite.

Então, na noite que eu estava lá ele acordou, de madrugada, e falou assim: "Eu tive um sonho. Eu sonhei que tínhamos que alimentar muita gente, muita gente mesmo". E ele sempre falava desse sonho de alimentar o povo, de ajudar.

Daí eu falei: "Padre Alfredinho, o senhor está melhor hoje?".

Ele falou: "Estou. Só estou esperando Jesus dar uma piscadinha pra mim e falar que chegou minha hora".

Assim, sabe, ele não perdia o entusiasmo. Ele sempre tinha uma palavra nova pra dizer para a gente, sempre. Muito bom...

É uma experiência muito boa, de vida mesmo, sabe. Eu tive, assim, um crescimento muito grande. E quanto mais a gente caminha, menos a gente caminha, né? Quanto mais a gente aprende, parece que a gente aprendeu pouco ainda, né? E a experiência que eu tive é que, realmente, o que Jesus quer da gente é o serviço. A gente se colocar para servir mesmo, na gratuidade, na alegria. Não é nem servir de ficar fazendo tanto, mas servir de estar junto, caminhar junto.

Eu só vou saber a realidade do pobre se eu for pobre junto dele. Eu nem preciso sair da minha casa para ser pobre junto com o pobre. Mas eu tenho que fazer uma experiência. Você tem que viver junto. E eu penso que é uma bagagem muito grande. A gente aprendeu muito. A gente tem que aprender muito mais. Crescer mais em todos os lados. Mas foi uma experiência muito rica, muito boa mesmo. Maravilhosa. Conheci muita gente boa, muita gente que realmente revela Jesus Cristo, muita gente que sabe falar de Deus com a vida, que leva esse Deus mesmo, de verdade, aonde ele caminha.

No convento também. Muitas irmãs que me mostraram o caminho. Só não consegui ficar lá, mas Deus estava também, com as pessoas...

Eu aprendi o desprendimento. Eu era muito apegada às coisas. Eu queria ter muitos sapatos, muitas roupas, muito tudo. E eu acho que até já falei... quando eu fui para o convento, daí eu passei uns dias aqui na Mooca. Estava um frio, uma chuva mesmo. Não sei se você lembra, mas aqui chovia tanto! Era um gelo. E daí eu peguei e estava lá, sentada.

Daí a secretária do colégio onde eu fiquei, lá na rua da Mooca, falou assim: "Madalena, essa moça trabalha aqui. Ela faz a faxina aqui do colégio. E ela não tem um agasalho, e está com muito frio. Você não tem um para dar pra ela?".

Eu falei: "Eu não. Eu só tenho três, eu vou dar um pra ela? Vou ficar só com dois? Ah, não vou dar, não".

Daí até essa moça falou assim: "Ah, você tem três. Ela não tem nenhum, né”.

Aí eu falei: "Ah, tá".

Então, eu fui lá e peguei um e dei pra ela. Mas eu era muito apegada às coisas. E eu acho que o que eu aprendi, tirei de lição, é o desapego. Hoje, eu posso dizer, assim, com louvor e alegria: não sou apegada a nada. E isso eu aprendi mesmo, na Irmandade, nas CEBs. Porque nas CEBs tem muito disso. Hoje eu não sei, mas antigamente tinha. A gente colocava tudo em comum. Nossa!, um levava o arroz, outro levava o feijão, outro não sei o quê. A gente partilhava tudo. E não era 'meu'.

E na Irmandade também eu aprendi muito. Eu tinha uma mania de ter muito sapato. Nossa, eu adorava sapato. Eu comprava de monte. Às vezes, eu ia e comprava 2, 3 de uma vez 
só. E agora não. Então, às vezes as pessoas falam assim: "Ah, é porque agora você não tem dinheiro". Mas antes, também, eu não tinha. Eu fazia crediário. Ficava pagando 3, 4 vezes, 5 vezes um sapato. Eu também não tinha dinheiro. E hoje, não. Hoje aquilo não me chama mais a atenção. Tem outras coisas mais importantes, eu penso. Então eu acho que eu aprendi isso: desprendimento das coisas da terra, material.

Eu penso que isso foi uma coisa que eu fico feliz. E também, eu acho, assim, que eu ouvi muito. A gente escutava muito. A gente escuta ainda, até hoje. $\mathrm{Na}$ Irmandade a gente fala muito de "a paz e justiça, tudo sem violência". Antigamente, se alguém falasse alguma coisa de mim, ah, eu já ia com quatro pedras na mão. Eu não queria nem escutar se era verdade ou se não era. Já ia estourando, e xingando e brigando e tudo. Agora, hoje não. Então, hoje eu vou na paz, sem violência, na tranqüilidade. Eu penso que isso foi uma coisa que eu aprendi, que mudou. Precisei passar por CEBs, pela Irmandade, pela catequese, para poder mudar. É um crescimento, como diz a Tetê, é devagarinho, é diário, é devagarinho mesmo para a gente mudar. Mas eu acredito que nisso, já tenho uma boa parcela de mudança. Acho que mudou.

Talvez hoje, com essa mudança que eu já tenho, esse crescimento, talvez eu não teria saído do convento. Você entendeu? Porque eu fui num impulso, né. E talvez eu não teria saído, teria continuado lá e encontrado um jeito de viver aquilo ali. Porque muitas irmãs que hoje estão lá, elas conheceram o padre Alfredinho, mesmo lá. Então, elas já tiveram uma outra visão. Mudaram. De todo jeito ia mudar, né. Talvez eu fui no impacto de querer uma mudança radical assim de cara. Eu penso que mesmo eu tendo o meu filho e que eu adoro - tenho o Nicolas* também, que é minha paixão -, mas talvez eu não teria saído do convento.

Então, eu acho que isso influiu no meu casamento. Que eu casei assim... namorei muito pouco. Primeiro e único namorado que eu tive. E eu vivi casada 4 anos e meio. É uma das coisas que talvez eu me arrependa de ter feito. Porque eu casei, acho que sem nem saber se eu queria mesmo aquilo. E eu penso que eu acho que casei porque eu tinha que casar, já que eu tinha saído do convento. Eu não sei, não sei...

Então, se eu tivesse continuado eu não teria casado, mas também não teria o meu filho, né? Mas assim, não sei... O meu filhinho chama Gustavo* também. Já te falei, né? Meu filhinho de 19 anos. Então, e depois já faz 16 anos que eu me separei. Nunca quis namorar, nem casar, nada. Então, talvez sejam as duas únicas coisas que eu, se eu tivesse um amadurecimento melhor, eu não teria feito. Não teria casado e não teria saído do convento.

A espiritualidade e a política comigo foi uma coisa encaixada na outra. Não sei se é porque a gente já foi mergulhando de cabeça e via, assim, a animação do povo. Então, eu achei que... Eu lido bem com essas duas coisas. Acho que eu não tive conflito, não.

$\mathrm{Na}$ verdade, quando você começa a lutar, querer uma mudança, tudo isso gera política. Vai gerando. Mas eu nunca tive problemas com isso, não. Foi uma coisa boa. Eu achei que foram boas essas duas coisas na caminhada juntas. Porque senão hoje eu não teria essa cabeça que eu tenho agora.

Teve a luta da creche. Nossa, a creche, a dona Hosana foi quem encabeçou. A dona Hosana, a Antônia, a Tina. Então, tinha muita necessidade de creche aqui nesse bairro. Porque as mães começaram a trabalhar fora. Até então, só os homens trabalhavam. Mas depois as mães começaram a trabalhar fora. Daí precisava de um lugar para as crianças ficarem. Tanto é que a irmã Rosina* morava ali embaixo, na Valentin Magalhães, e ela ficava com muitas crianças, para as mães trabalharem. E daí começou a luta.

A gente trabalhava e tinha muitas reuniões aqui para reivindicar, para pedir, para fazer. Então, eu lembro que a gente combinava de ir pra prefeitura juntos para fazer grupo. A gente ia para fazer... para juntar gente, né. Iam algumas mães e a gente ia junto. 
E eu falava assim: "Mas eu vou lutar por creche pra quê se eu nem vou casar, se eu nem vou ter filho? Mas, vam'bora. Se o problema é lutar por creche, vamos".

Olha, mas foi uma luta de mais ou menos uns 5, 6 anos. Uma luta grande. Então, foi quando eu saí... eu casei em $89 . .$. você vê, foi um tempo curto de eu sair do convento. Foi nessa época. A gente lutava. Eu entrei de cabeça na luta da creche. Daí foi... eu casei em $89 . .$. e mesmo assim eu ia lá. E daí eu tinha 2 anos de casada, foi quando saiu o projeto. Eu falei, "nossa". E vai lutando, e vai, e vai. E nunca saía do papel.

E dona Hosana falou: "Não, não podemos parar. Nós temos que continuar".

Quando foi... o meu menino tinha uns 2 anos e meio, inaugurou a creche.

Daí eu falei: "Mas rapaz, eu vou ter que fazer a inscrição desse menino para a creche". E não é que ele foi um dos primeiros... O primeiro ano de creche ele estava lá. E 5 ou 6 anos atrás eu dizia que nem ia casar, que nem ia ter filho. E daí, ele inaugurou a creche.

Então, a gente lutou e conseguiu. E o Celso Daniel* ficou 4 anos. Foi feito na gestão do Celso Daniel. A gente conseguiu. Depois o Brandão veio e fechou a creche 1 ano. O Celso Daniel já ia inaugurar. Mas ele terminou, ele perdeu a eleição, que era o Cicote* que tinha concorrido e perdeu. Daí, o Celso Daniel ficou 4 anos fora da prefeitura. Daí, o Brandão voltou. E ele deixou a creche fechada 1 ano! Dizendo que tinha infiltração, que tinha isso, que tinha aquilo, para ele poder inaugurar no final. Daí, foi quando as crianças começaram. Depois o Celso Daniel voltou.

Daí o Brandão queria pôr o nome de uma parente dele, Laura* não sei das quantas. Mas a gente já tinha dado o nome de 'Irmã Rosina'. O Celso Daniel tinha até inaugurado com o nome de 'Irmã Rosina', tudo. Só que entrou o Brandão, não funcionou a creche. Daí, ele veio com um nome, acho que era Laura. Ah, mas nós pegamos firme. Daí, foi uma luta para sair pegando... fazer abaixo-assinado, pegando assinatura. Mas não demorou, não, porque rapidinho a gente conseguiu. E depois ele inaugurou: 'Irmã Rosina'.

Agora, o ano passado a moça da creche me chamou lá. Eles vão ampliar a creche.

Daí, eu falei assim: "Mas, olha, já vou te avisar de antemão. Se a ideia deles é trocar o nome, eu começo hoje um abaixo-assinado".

Ela falou: "Não falaram nada de mudar o nome, não. Acho que não vai mudar o nome, não".

É porque a irmã Rosina lutou pela creche. E ela ficava com as crianças. Ajudava as mães. E ela lutou. Vinha junto nas reuniões, conversava boca a boca com o povo. Porque tem muita gente que tinha que ser no boca a boca pra poder ir. Como hoje. Hoje, tem uma reunião para discutir qualquer projeto, ninguém vem. Tem que ir no boca a boca para ver se consegue. Mas eu acho que a gente se acomodou. Eu acho que nós estamos achando que está tudo bom agora, né.

Eu acho bem diferente as CEBs de antes e as CEBs de hoje. Eu acho que só reza hoje. Só faz aquele grupinho nas casas. Eu penso. Porque eu falo, assim, tiro uma experiência. Na minha rua tem um grupo. Eu não vou lá no grupo por quê? Eles se reúnem de segunda-feira, às 2 horas da tarde. Quem trabalha não tem como ir. E na minha rua tem uma mulher acamada, que tem Mal de Alzheimer e a filha dela é uma luta para cuidar daquela moça. Antigamente, as CEBs faziam isso. Ela ia ficar um pouquinho com a pessoa que estava doente para o outro descansar um pouco. E hoje a gente não vê isso.

A minha vizinha - que eu acho que já te falei - teve um câncer na medula... ela ficou muito tempo sem andar. Agora ela está voltando a andar. Mas não apareceu uma pessoa do grupo para fazer uma visita pra ela, sabe. Eu acho que isso deveria acontecer. Só que não acontece. Então, eu acho que eles estão muito só na reza, sabe. Reza, vem aqui, pega aqueles livrinhos de novena, reza aqueles 'Fatos da Vida', que eles nem sabem que 'Fatos de Vida' são esses... E daí, eu acho que eles deveriam... não sei, é o meu pensamento... que deveriam 
começar a rezar a vida do povo, rezar a vida da nossa comunidade, a nossa vida, celebrar a nossa história, os acontecimentos de hoje.

Então, vocês viu eles falando? A mulher, há 8 dias que pediu a comunhão. Foram levar hoje, o homem tinha morrido já. Há 8 dias já morreu. Então, assim, não sei o que está faltando. Não sei o que nós temos que fazer.

Faz uns 10, 11 anos que eu saí das CEBs. Desde que eu entrei na Irmandade. Daí, só fiquei com a Irmandade. Eu ainda faço Grupo de Rua, mas com as crianças, na minha rua. Duas vezes por ano. A gente celebra na Páscoa e no Natal. Mas as CEBs mesmo, em si... eu venho quando tem encontro aqui das CEBs. Mas participar mesmo de Grupo de Rua, assim... Porque na minha rua, infelizmente, é durante o dia. Então, para mim fica mais difícil.

Não chamava 'Grupo de Rua'. Chamava 'Círculo Bíblico'... 'Encontro de CEBs', a gente falava. Antigamente, a gente nem tinha tanto material. O nosso instrumento era a Bíblia mesmo e a vida do povo. Então, aí a gente fazia as apresentações, fazia os encontros, pegava o endereço onde você morava. Daí, já tirava dali uma pessoa para poder ir te visitar. Pelo menos, no tempo em que eu participava era assim. Depois que ia te visitar, se você voltasse no grupo mais uma vez, perguntava se você queria um encontro na sua casa.

Daí, marcava o encontro e vai chegando gente, vai chegando. Daí, oração, e depois fala dos Fatos da Vida. Só hoje que nem tem Fatos da Vida. Mas aí a gente vai ver. "Ah, vocês estão sabendo que fulano perdeu o emprego, não sei o quê...", né. Daí, começa: "Tem 4 filhos, mulher não trabalha. $\mathrm{O}$ que a gente pode fazer pra poder dar uma assistência nesse primeiro momento?". Era mais ou menos assim. E aí, um vinha com uma outra história também, tinha um outro caso para falar. E assim ia.

Chegava, fazia uma oração, lia a Bíblia. O bom é que a gente lia a Bíblia, não tinha um

seguimento, antigamente. Hoje, não. Hoje você pega os livrinhos prontos. É esse texto que bate com esse, né. E a gente, não. Mas, depois, no fim tudo batia, tudo dava certo.

Não tinha livrinhos antes. Daí começou a fazer aqueles bem fraquinhos, em casa mesmo. Tirava xerox.

Daí, hoje: "Quem vai preparar o encontro de semana que vem?”.

"Madalena".

Aí, eu lia a Bíblia ali, achava um texto, e aquele texto a gente ia rezar. E, às vezes, era tão inspirado pelo Espírito Santo que batia com os fatos que se ia colocar. Às vezes, não tinha nada a ver. Mas, às vezes, dava certo. E batia. E foi assim, fui fazendo também um seguimento, um roteiro. Quando os padres... quando o padre Mahon mesmo começou a ajudar, a gente já fazia um roteiro.

Nossa, era uma CEBs boa, bem gostoso de participar. A gente tinha gosto, dava vontade de ir. Era semanal. Sempre à noite, 7 e meia, 8 horas.

E aquilo era cantado, cantava, cantava. Ai, como eu gostava! Tinha um canto que eu gostava demais de cantar:

Peregrino nas estradas

De um mundo desigual.

Espoliado pelo lucro

E ambição do capital. (cantado)

Era bonito! E cantava! Eu sei que o final falava assim:

"Lutar não foi em vão", né.

E nos palácios do olêlê, olêlê

moram os príncipes

sem saber que lá fora 


\section{que lá fora}

a vida é triste. (cantado)

"E existe", né, "a vida é triste e existe", lá fora. Mas era muito bom. E a gente era jovem. O Grupo de Jovens também cantava. Eles participavam. Eu participava do Grupo de Jovens, ia nas CEBs, ajudava a animar as missas aqui, participava da liturgia. Muito animado. Cantos de CEBs. Fazia tudo com músicas de protesto, né. Como a gente não podia falar, então a gente cantava. Cantava a vida.

Essa igreja ficava lotada. Era de final de semana. É. E com almoço. Ficava o dia inteiro. A gente saía para fazer encontro no Pedroso, encontro no parque, em outros lugares também. Muito bom. Tinha umas irmãs que vinham aqui para poder falar. Tinham outras também. Leigos, pra dar palestra para a gente. Sindicato vinha. Vinham algumas cooperativas. Vinham sempre algumas cooperativas pra passar experiência para a gente.

Candidatos de CEBs foi mais pro fim. Teve o Fúlvio que saiu candidato, que era das CEBs. Teve mais alguns que eu não estou lembrada agora o nome. Só que assim, nenhum... não ganharam. Aí teve um que ganhou e se corrompeu. Acho que depois que entra lá é meio complicado. Mas o Fúlvio se candidatou duas vezes. Ah, teve o Dino também, que se candidatou e não ganhou. É, foi o Dino, o Fúlvio e, depois, por fim, a Tina. Mas aí, quando a Tina entrou na política, ela já não tinha mais tanta ligação assim. Não tinha mais movimento na igreja, não. Ela até que tentou, assim, mas não continuou.

Mas no início, pelo menos aqui na nossa redondeza, o povo lutava mesmo sem nenhum candidato. Vinha o sindicato para poder dar um apoio, porque tinha bastante gente de fábrica que participava das CEBs. E tinha essas cooperativas também, que vinham, para poder dar um apoio, uma ajuda. E tem a... ai, como ela chama? Que juntou um pouco, também, com o movimento da favela... MDDF. Mas esqueci o nome dela. Aquela lá foi uma lutadora também. Que também é sobrinha da dona Margarida. A Otacília. Ela fazia parte do movimento da favela aí. Ela botava pra quebrar. Ajudou bastante, a Otacília. Mas... agora hoje está meio sossegado, meio paradão.

Nos encontros de CEBs, os Fatos da Vida eram: um barraco que tinha caído, uma casa que caía... pôr laje. Esses eram os 'Fatos da Vida'. E se surgia alguma coisa maior para a gente fazer, sempre vinha aqui fazer uma reunião na igreja. E juntava todo mundo para poder reivindicar uma coisa maior, assim. Tipo creche, luz, água, ônibus. Era discutido no grupo, mas a decisão maior mesmo era sempre aqui, com as lideranças. Sempre os líderes vinham, os coordenadores dos grupos. Vinham e depois levavam o resultado para o grupo. Daí, lá se discutia a melhor forma do que a gente ia fazer, quem ia, quem podia ir, o que podia fazer. Discutia-se tudo. Às vezes a pessoa foi mandada embora e o acerto não foi direito. Daí, tinha pessoas para orientar. Falava muito de salário.

Surgiram muitas amizades das CEBs. Muitas amizades. E que ficaram até hoje. Que nem a família Bento. Nossa, são uns amicíssimos. Começamos aqui juntos e estamos aqui até hoje. Eles não participam mais ativamente na comunidade, mas eles vêm à missa. Agora são assembléia. Não têm mais uma pastoral. Só que a nossa amizade está fundamentada. A gente tem uma amizade muito grande. Com a Magrinha - a Fátima* -, a Cidinha*, a dona Alice*, a dona Messias, o pessoal do sobradinho também, que a gente participava juntos - a dona Teresa*. Ficou. Gente que está aí sempre. A dona Maria*. Fica, né. De vez em quando a gente senta, começa a lembrar e fica saudade. Lembra com saudade. Mas valeu a pena, viu. Valeu a pena ter vivido tudo isso. Tudo. 
Nunca fui num Intereclesial. Regional, sim. Mas Intereclesial, não. Sempre iam mais as pessoas que estavam na liderança. Mas nós tivemos um encontro grande, bom, foi lá no Parque Celso Daniel, lá no Duque de Caxias. Fizemos um teatro, até, para apresentar lá. O Fabrício é que ensaiava a gente. Ele era jovem também. E esse daí eu lembro, desse encontro que nós tivemos. Era tanta gente, mas tanta gente. CEBs da Diocese inteira. Esse era da Diocese. Agora eu quase não vejo... às vezes acontece um encontro aqui. Aqui tem os intereclesiais, que elas vão, as meninas vão. A Leda e a Flávia, a Dalva.

Nas CEBs, a maioria era mulher. Eram poucos homens. A maioria era mulher. A força da mulher.

Muitas mulheres apanhavam dos maridos. Tinha bastante. Muita agressão. E muitos problemas com filhos, porque, às vezes... no parto. Muitos problemas vinham. Mais era alcoolismo. Sofriam com o marido em casa. Apanhavam, tudo. E tudo isso acontece hoje. Não sei se as mulheres têm vergonha de falar. Mas antigamente se tinha muito mais. É difícil você descobrir. Quando você descobria que uma mulher era agredida em casa por causa do marido, porque ele bebia ou sei lá, era mais difícil. Hoje em dia está mais difícil.

E eu achava interessante que para chegar no grupo, primeiro... vamos supor, eu ficava sabendo, daí juntava, convidava alguém que ia fazer uma visita, depois trazia para o grupo, nos 'Fatos da Vida'. "O que a gente pode fazer?". Não ficava sem a solução. "O que nós podemos fazer para ajudar?". Se a gente não podia fazer nada, então também não ia mexer. Agora, se a gente tivesse como arrumar um jeito, a gente mexia.

Tinha uma família em que o homem tinha um revólver. E bebia. E ele ficava dando tiro pra cima. Não dava tiro nas pessoas, dava pra cima. Como essa mulher sofria! Meu Deus do Céu! Ela vivia sempre de cabeça baixa, sempre. Daí, eu lembro que nesse caso teve uma interferência. A mulher foi até ficar uns dias na casa de uma outra pessoa. E daí, fomos conversar. Fomos conversar com o homem. Não lembro quem que foi... Não sei se foi a Lia... Foram várias vezes conversar com o homem. Queriam ajudar ele a sair do vício. Conseguiram tirar o revólver dele, sabe. Depois, a mulher voltou para casa. Ainda assim, de vez em quando ele bebia. Deu ainda uns tapas nela, mas foi melhorando. Então, daí ele já aceitou que a gente rezasse na casa dele. A gente ia rezar lá. Fomos várias vezes, várias vezes.

Daí, eu não sei se ele parou... não estou lembrada agora. Mas eu sei que melhorou muito. Melhorou bastante. Mas não foi uma coisa da noite pro dia, não. Primeiro foi uma conquista do espaço, da confiança. Depois, para a gente poder ir rezar lá. Eu acho que a Edilene é que foi junto com uma outra pessoa... a dona Dinha, não sei... Que elas iam primeiro, conversavam com ele. Quando a mulher voltou, elas foram lá. Um dia, chegaram lá, ele estava chegando bêbado, caindo, ajudaram ele a subir. Porque lá era muito morro, ainda é muita escada. As casas, assim, tudo cheias de escadas.

E eu sei que devagarinho marcaram um terço lá. A gente foi. Tinha a dona Maria, ela sempre contava uma história, sabe. Acabava quase que falando daquela pessoa mas, assim, de um outro jeito que dava certo. E ajudava bastante. Era bom. A dona Maria faleceu já. Era uma das mulheres dos Bento. Dona Maria está no Céu.

O que me marcou mais foi o primeiro dia que a dona Margarida chegou lá em casa. Esse dia marcou. E eu não queria ir. Eu queria ver a televisão. Mas, aí, nós fomos. Então, eu acho que isso eu não vou esquecer nunca desse dia.

E depois, num dia também que nós fizemos uma celebração, um casamento comunitário. Esse casamento foi até o Alfredinho que fez. Foi assim, conversando com a família, com o povo. Tudo isso serviço de CEBs. E daí, juntou aqui nessa igreja tanta gente para se casar. Ficou cheio. Esse dia também, nossa, não vou esquecer. Tantas pessoas que já moravam juntas há muito tempo, daí eles vieram para esse casamento. Foi o primeiro casamento comunitário que aconteceu aqui nessa igreja. 
No dia desse casamento, quem casou foi uma moça que mora aqui perto da igreja. Nesse dia ela casou. Ela já vivia com o marido dela, tudo, mas teve esse casamento. Então, eu acho que esse dia foi muito importante. Achei que foi um dia maravilhoso, que também vai ficar escrito. Está marcado. No dia da primeira missa lá no Vista Alegre. Também foi uma coisa muito bonita: a primeira missa lá no Vista Alegre.

Ó, eu penso que todos sejam o início de uma vida nova. Os três momentos. Você vê, a dona Margarida me convidar foi o início de uma caminhada nova na minha vida. E o casamento aqui. Eles viviam juntos, e daí eles foram, vieram viver o sacramento para a mesma vida, mas de um jeito novo de viver, uma caminhada nova. E lá, aquele povo. Que esperança que eles tiveram! Foi uma caminhada nova. Uma esperança incerta, que eles podiam ser expulsos a qualquer momento, mas ficaram firmes ali. E estão lá até hoje. A gente sente muito que tantas outras coisas também estão lá, né. Mas essa luta...

Eu achei três momentos muito bacanas. E teve tantos outros. Padre Mahon, nas caminhadas dele por aí afora. Sentava numa lambretinha aí e se mandava. (risos) Eu não sei se era dele, mas eu sei que ele andava sempre com uma lambretinha. Ele tinha um outro carro. Tinha um carro também depois... não sei se era Brasília... não lembro que carro que era. Carrinho velho, mas ele andava. Sempre presente, sempre presente. Tinha um mutirão, podia saber que ele estava lá. Tinha outra coisa, estava lá.

Muitos mutirões tiveram aqui. Muitos. Mutirão... Pra construir casas, levantar barraco, construir igreja. Foi muito bom.

Nossa, voltei ao passado! (risos) Você viu, estou até mais animada, né. Nossa, dá um ânimo na gente, a gente lembrar de tudo isso. Que a gente tinha FORÇA para fazer tudo isso. Hoje acho que não tem mais. Mas a gente se anima. Só de pensar a gente se anima. É um ânimo novo. Uma vida nova. E eu fico feliz com tudo isso. Tanta coisa boa já aconteceu, e vai acontecer, com certeza, na vida do povo. Para construir essa história. Continuar a vida em Deus.

Sou CEBs desde pequenininha. Sem saber. Mas eu falei pra você da minha mãe, né. Minha mãe era muito, nossa... minha mãe era muito generosa. Ela recebia, acolhia muitas pessoas na minha casa. Muitas. Sempre viveu, assim, essa 'Porta Aberta'.

Então, assim, até há pouco tempo eu tinha um cartaz lá em casa, na minha porta: "Porta Aberta aos Famintos". Daí, o meu irmão tinha um amigo que vivia drogado, assim... Daí, ele chegava lá com esse amigo dele e falava assim: "Entra, Henrique. Aqui é 'Porta Aberta aos Famintos"”. (risos) E esse amigo dele sempre ia lá em casa quando estava muito ruim, que não podia ir para casa. E a gente conversava com ele, falava, falava, perguntava se ele não queria participar dos grupos, de alguma coisa. E ele nunca quis.

Aí, eu lembro que a minha irmã veio do Ceará, do Nordeste. Na véspera do Ano Novo a gente foi dormir, e ela falou assim: "Quando passar pro dia primeiro, a primeira pessoa que bater na nossa porta vai revelar para nós como será o nosso ano".

A gente acabou de deitar, daí bateram na porta. (risos) Era o Henrique. Eu falei: "Nossa Senhora, a nossa vida vai ser uma catástrofe!" (risos)

E daí, ele entrou todo assim, foi acho que o melhor "Feliz Natal" que eu recebi. Ele entrou e falou: "Feliz Natal! Feliz Ano Novo pra vocês! Eu vim desejar um feliz Ano Novo". E, assim, tantas mensagens boas que ele falou. E começou a chorar.

Eu falei para a minha irmã: "Ah, eu acho que vai ser um bom ano".

$\mathrm{E}$, nossa, de onde a gente menos espera é de onde brota algo novo mesmo, uma vida nova. Porque quando o meu irmão ficou muito doente, um dia ele chegou lá em casa. E era bem magrinho, consumido pelas drogas. Mas ele não mexia em nada de ninguém. Ele usava com o dinheiro que ele tinha. 
Daí, um dia ele chegou lá em casa e eu falei: "Ih, Henrique. O seu amigo não está bom, não. Não quer comer, não quer nada".

Ele falou assim: "Me dá o prato".

Eu dei o prato. Fiz uma sopa bem leve. Daí, ele sentou na cama. Menino, mas ele pôs a comida todinha na boca do meu irmão. Meu irmão não tinha força para comer. E, olha, eu não tive essa ideia. Eu falei: "Ah, ele não quer comer...". Ele foi, sentou lá e deu toda a comida. Meu irmão comeu tudinho. Daí, pegou a água. Meu irmão não conseguia beber. Ele pegou um canudinho, pôs dentro do copo, meu irmão tomou.

Daí, passou, acho, que uns 10 dias, ele teve pneumonia. Foi internado e ficou uma semana e faleceu. Morreu. E o meu irmão morreu uma semana depois dele, certinho. No dia da missa de sétimo dia dele, eu estava com o meu irmão no hospital. Daí, o meu irmão morreu na madrugada. Oito dias, certinho. Falei: "Nossa Senhora". E ele precisou vir aqui para fazer, assim... E, nossa, todo mundo ficava falando comigo e com a minha irmã: "Vocês deixam ele entrar lá. Ele não sei o quê...". Eu falei: "Gente, ele é o melhor amigo do meu irmão". Mas o meu irmão não usava droga. Mas ele tinha compaixão dele. Ele sempre ajudava esse moço. E ficaram, assim, amigos.

A minha irmã fica assim: "Como é que nós vamos dizer, agora, quem é que vai pro Céu? Quem é que vai ser recebido por Deus, diante desses fatos? Quem?”. A gente não sabe. Não sabe. Nossa... Foi muito engraçado. Ele morreu no dia 26 de novembro e meu irmão dia 4 de outubro. Fez 4 anos agora, esse ano. Precisa passar, né. É tudo lição. A vida, realmente, é uma escola. 


\subsection{João}

Eu nasci no Paraná, num lugar chamado Rolândia. Nasci em 56. Foi dia 23 de junho de 1956. E lá eu fui criado. É perto de Londrina. Faz divisa com Arapongas, Cambé e Londrina. Rolândia é uma cidade colonizada pelos alemães.

E a gente trabalhava com o café. E eu nasci lá e fui criado na roça. Meus pais eram pobres. Não tinham condições de ter um sítio, então trabalhavam por porcentagem. Quarenta por cento do que eles faziam, pegavam para eles. E sessenta para o patrão em forma de café. $\mathrm{O}$ arroz ficava com o meu pai, que era menos. Agora, o café, dava sessenta para o patrão e ficava com quarenta. E adubava o café - dava o adubo -, o meu pai passava, mas ele se encarregava de carpir, de limpar o café onde ia derriçar - eles falam 'derriçar' o café -, derrubava, rastelava, abanava, montava no saco, e levavam até o terreirão para secar. Aí, andava com aquele saco nas costas até o carrinho, e levava no terreirão para secar. E aí secava, depois de vários dias de sol. Abria num ponto certo e guardava numa tulha. Era um lugar que guardava... tipo uma casa assim, sem janela, só com a porta. Chamava 'tulha'. E jogava lá dentro o café para depois ver o melhor preço para vender.

Então, era muito sacrificado. Muito. E dinheiro, na época, era mais na colheita, quando recebia. E aquele dinheiro tinha que dar para o ano inteiro, depois. $\mathrm{O}$ arroz e o feijão plantava, mas era só para comer. Não dava para vender. E eles viviam do café. O café, o ano que dava bastante, o outro ano dava menos. Então passava apertado. O dinheiro que fazia num ano, tinha que guardar para segurar no outro ano. Senão, passava fome. Então era aquele sufoco.

Nós éramos em 8 irmãos - 3 irmãos e 5 mulheres. E 3 morreram por falta de um acompanhamento médico, que minha mãe não tinha. Não tinha pré-natal igual hoje. Era na roça, era parteira. Eu mesmo fui na parteira. Minha mãe começou a passar mal para me ganhar, aí o meu pai foi pegar a égua no pasto para buscar a parteira - uma senhora que tinha longe, lá - e a égua não deixava o meu pai pegar, e corre daqui atrás da égua, corre atrás de lá e vai, vai, vai... Conseguiu pegar a égua mais de meia hora depois. A hora em que chegou lá, eu já estava do lado da mãe, já tinha nascido. A minha mãe e eu, nós dois. Ela acabou fazendo sozinha. Mas ficou lá emendado. Aí, o meu pai ainda foi buscar a parteira, a parteira veio e cortou o umbigo.

E aí a gente foi vivendo aquela vida sofrida. Eu lembro que com 4 anos eu já ia ajudar a apartar bezerro. Tinha uma vaquinha para dar leite lá. E depois, eu, com 7 anos, já ia para a roça. Com 7 anos. Ia limpar tronco de pé de café. Que derriçava o café e ficavam aqueles cafés caídos no tronco, e você precisava limpar assim, e puxar com o rastelo. E a gente era moleque, com 7 anos já começava a limpar.

O meu pai ia plantar arroz também, e plantava com a máquina e o buraco ficava aberto, você ia com o pezinho atrás, ia tampando as covinhas. E aí, depois, comecei a ir para a escola, vinha da escola e ia para a roça. Vinha da escola e ia para a roça. Dia de sábado, a gente trabalhava até duas horas, uma hora da tarde. E depois da uma hora da tarde a gente ia rachar lenha. O nosso fogão era a lenha, não tinha fogão a gás. Então, tinha que rachar a lenha para queimar. E também não tinha energia em casa. Não tinha geladeira, a água vinha de mina, no bambu - cortava aqueles pés de bambu, grandões, e aí a água vinha correndo dentro do bambu e chegava até a caixa perto de casa lá. Aí catava a água.

Para tomar banho, na época, era um balde. Aí, esquentava no fogão, punha água morna lá, levantava e tomava banho. Mas tomava banho mesmo mais dia de sábado, sábado e domingo. Durante a semana só lavava o pé e a cara, e mais nada. No meio da semana era só lavar na bacia. Lavava e jogava aquela água e esquentava e vinha e lavava, todos os irmãos. Então, era aquela família reunida. 
Quando chegava de noite, contava caso. O meu pai contava caso para nós. Os filhos ficavam reunidos tudo em volta dele. Aí, outra noite da semana, tinha terço. Ia nas casas dos vizinhos com farolete, que era muito escuro, era o lampião. Era o lampiãozinho. Ia com o lampiãozinho nos terços e voltava. Ia dormir cedo - dez horas já ia dormir. Então foi uma passagem de vida... fazia hoje para comer amanhã.

E depois ia ficando mais rapazinho, durante o domingo, na colheita de café, tinha que esparramar o café no terreirão, dava o sol, ficava mexendo, aí depois que amontoava, duas horas da tarde, estava quente, amontoava o café e botava ele quente para ir secando. Para ficar mais no ponto. Aí é que nós íamos passear, depois das duas horas da tarde. Aí, nós íamos no campo de bola. Ficávamos no campo de bola, arrumava namoradinha lá. Já era rapazinho.

E aí, rapaz, eu já estava apanhando café, abanava o café, para tirar os ciscos. Apanhava no saco, e aquele saco pesava sessenta, setenta quilos. E eu com doze anos, treze, já apanhava um saco de sessenta, setenta quilos nas costas, e ia levar até a carroça. Na colheita de café, a gente saía e ia, de madrugada. E tinha vezes que geava. Você chegava para abanar o café e tinha gelo por cima. Pegava aquele gelo... Quantas vezes que eu entrei debaixo do pé de café ali, limpando, encontrava escorpião, batia na mão assim! Escorpião, aranha. É que Deus cuidava muito da gente.

Uma vez só que eu fui picado por uma caranguejeira. Mas o que eu fiz? Sem saber, eu fiz um cortinho por cima assim, onde ela ferroou, matei ela e passei a barrigada em cima do corte. A dor sumiu. Estava aquela dor do caramba, e a dor desapareceu. Era uma caranguejeira peludona. E aí, aliviou. Graças a Deus não deu febre, não deu nada. Então, é coisa da roça. E a mocidade foi crescendo.

Mas desde pequenininho eu tinha vocação de ir na igreja. Desde pequenininho. E ia de bicicleta na missa. Tinha um sitiante lá que tinha um caminhão. A gente ia tudo no caminhãozinho dele, todo domingo. E quando chovia, às vezes a gente ia até a pé. Ia na igreja, OITO quilômetros longe de onde a gente morava!, na cidade de Arapongas, que ficava mais próxima do que Rolândia. Que eu morava no município de Rolândia, mas Rolândia ficava uns dez quilômetros longe, e Arapongas ficava oito. Então, a gente ia mais perto, em Arapongas. Quando chovia, para voltar era terra vermelha. Aí, a roda não girava, virava aquele barrão, trazia a bicicleta nas costas. Você vai andando assim, vai colando, que nem um sapato igual ao seu aí, você vai indo, vai virando aquele montão de barro. Barro vermelho vai colando. Você vai andando que nem um pato, vai batendo e vai colando. De vez em quando você precisa parar e limpar o pé para continuar. Senão não ia. Senão está ferrado. Era fogo, meu, a minha mocidade... Não foi fácil, não.

Nas casas tinha uma enxada de carpir ou o rodo. Tinha dois pauzinhos, ali no meio assim. Você chegava na casa e tinha que passar o pé lá para entrar. As casas tudo de madeira. Não tinha forro. Era um lugar em que muitas pessoas pegaram aquele bicho barbeiro, percevejo. Nós tivemos sorte que na nossa casa não tinha percevejo. Porque aquelas mais antigas eram cobertas, eram feitas daquele barro. Fazia barro e iam fazendo, coberta de sapé. Aí dava um percevejo danado. A nossa era de madeira. Madeira já era mais tranquilo. Mas muita gente se ferrou.

Domingo à tarde ia jogar bola. Era uma turma feliz, era um povo feliz. Aí, ia acabando nas colheitas todo mundo, e quem acabava primeiro ia ajudar o outro que estava para o fim. Fazia um mutirão. Ia ajudar o outro que não tinha acabado ainda. E não cobrava nada, só dava comida. Aí, acabavam tudo as colheitas. Depois vinha plantar arroz e carpir.

Olha, eu fiquei na roça até 19 anos e meio. São momentos da vida da gente que a gente fala assim: "eu era feliz e não sabia". Não tinha conta de água para pagar, não tinha luz, não tinha nada. A luz era lamparina. Meu pai comprava querosene só. Às vezes, se você estava numa casa - era casa de madeira - e se você esquecesse a lamparina ligada sem apagar, dormia 
e cochilava, no outro dia ela já tinha apagado e tinha acabado a querosene. E ficava tudo preto. Aquela fumaça que ficava presa dentro de casa. Passava a mão na perna, assim, era preto, da fumaça dela...

E o nosso colchão de dormir não era mola, era palha de milho. Nós pegávamos palha de milho - era palha seca -, e aquele monte, tirava o milho, ia rasgando ela, ia afofando e colocava no colchão. Então, dormia naquele colchão de palha de milho, travesseiro de palha de milho... Não, o travesseiro era de pena de galinha. Colocava pena de galinha... Tudo coisa natural.

Não tinha sofá a sala. Eram aquelas mesonas brutas, aquelas cadeiras de madeira, aquele fogão de lenha, que enchia de fumaça. Quando a lenha estava meio molhada, não pegava fogo e enchia de fumaça a casa, ficava tudo preto. Olha, aquilo é vida hein, meu. Para o cara aguentar não é fácil, não. Hoje eu não aguentaria. Mas na época, você está criado aí... E era uma vida saudável.

Nós andávamos descalços. Eu comecei a usar sapato depois de 14 anos. Ia na missa com o sapato. Tinha um sapato para ir na missa de domingo. Mas ia trabalhar descalço. Quantas vezes que eu ia para a escola descalço. Botava um chinelinho havaianas, uma alpargata no pé. Usava alpargata na época lá. Não tinha esse negócio de frescura, de tênis. Negócio de tênis saiu bem depois. Não tinha energia, não tinha geladeira, não tinha nada. Era aquela vida de pobre mesmo. Fazia hoje para comer amanhã.

A gente não tinha nada. Um amor no pai terrível... um amor no pai, na mãe, era tudo... que a gente era o pai e a mãe. $\mathrm{O}$ que eles tinham... a gente não tinha nada porque não tinha dinheiro mesmo. Mas quando o pai pegava, só faltava dar o coração para a gente, de tão bom que ele era. Minha mãe... a gente ficava sem nada porque não tinha, o meu pai também não tinha. Era uma vida pobre. Na roça é pobre. Fazia hoje para comer amanhã. Colhia o café uma vez por ano, ia vender o café. O dinheirinho que fazia tinha que guardar, tinha que dar o ano inteiro. Aí, no outro ano não dava quase café. Ih... era fogo. E o arroz que fazia, era para comer. Feijão para comer. Plantava amendoim, quase não sobrava para vender. $\mathrm{O}$ que dava mais era café para vender. E lá o resto das coisas, milho também... É fogo rapaz... nós passamos uma situação difícil.

Os nossos brinquedos, de moleque, de rapaz, era tudo feito em casa. Era feito carrinho de pau. As rodinhas se fazia de carretel. E quando foi crescendo mais, naquela época usava o mesmo carrinho, mas de roda de madeira. Nós fazíamos roda de madeira certinho e soltávamos na estrada, com o breque. Usava os mesmos carrinhos. Só que a roda era de madeira para rodar na terra. Então, a gente tinha criatividade na roça.

As meninas não tinham boneca. O que elas faziam? Espiga de milho. Pegava boneca de espiga de milho e fazia a boneca. Enrolava, brincava com a espiga de milho. Eu achava até que naquela época as crianças eram mais criativas do que hoje. Eles faziam os seus próprios brinquedos. Hoje, não. Eles compram pronto, né. Naquela época, nós fazíamos o nosso brinquedo. Então, era interessante, muito interessante.

A gente ia em baile também. Os bailinhos de sanfona. E não tinha dinheiro para pagar, chegava meia-noite, eles vinham cobrar e a gente se escondia... (risos) Era uma vida sacrificada. Aí, eu via a turma tomando cerveja assim, aqueles caras sitiantes que tinham dinheiro. Tomavam... batiam na barriga assim e eu olhava com aquela vontade!, rapaz. Eu olhava e falava assim: "Ô meu Deus, será que um dia eu vou poder tomar cerveja igual esse cara está tomando desse jeito? Olha como é que ele toma cerveja...". Tinha uma vontade de tomar e não podia. Não tinha dinheiro. Passava vontade de tomar. 
E para comer uma paçoquinha, no final de semana... a gente ia com o dinheiro para comer uma paçoquinha. E aquela paçoquinha a gente sentia bem o gosto dela.

E para tomar um guaraná, assim, um refrigerante, era mais na Páscoa, no Natal e no Ano Novo. Que o pai comprava uma caixa e dava para a gente. O que nós fazíamos? Eram aquelas guaranás pequenininhas. A gente chacoalhava, furava com um preguinho a tampinha, e ficava chupando para durar bastante. É uma vida...

Quando conseguia aquilo... Nossa senhora! Era maravilhoso! Mas, também, era tudo natural. Não tinha nada de ensacado. E não ia em médico...

A gente comia arroz, feijão... não tinha óleo, era gordura. A gente tinha porco e matava porco. Como não tinha geladeira, para não estragar a carne, fritava toda aquela carne e fazia lá. Fazia torresmo e carne frita. Pegavam aquelas latas de banha de 20 litros, com aquela tampa. Aí, dava uma lata de gordura, duas, e colocava a carne no meio da gordura. E depois ia fazer na comida, tudo panela de ferro, lá naquele fogão a lenha. Aí, pegava a comida, já pegava a carne que estava no meio da banha, esquentava ela e a gente comia aquela carne, esquentada, que estava conservada. Nossa, é demais de gostoso!

A carne de porco natural, não tem pra ninguém. É uma delícia. E muita galinha também. Quando não tinha porco tinha galinha. Matava galinha... A minha mãe fazia muito polenta. É, rapaz... aquela turma no meio de italiano, né. E eu falava: "Pelo amor de Deus, eu não gosto disso...".

"Você vai ter que comer".

"Eu não quero mais polenta. Eu não aguento mais tanta polenta...".

"Vai ter que comer polenta".

E tinha que comer polenta, senão passava fome. (risos) Era obrigado a comer. Hoje em dia, a polenta é mais saudável. Dá saudade daquelas polentas fritas. Hoje é uma delícia. Naquela época, meu... Nossa, né.

"Não, eu não quero... não quero....".

E pão era um pão. Pegava um pão, cortava uma fatia cada um... Encheu, encheu. Não encheu, não podia pegar mais. Era aquele pão para a turminha: para o pai, para a mãe e para os filhos. E minha mãe fazia pão dia de sábado. Fazia um forno lá com 8 ou 9 pães. Aí, comia no sábado um, no domingo comia um, dois, e ia levando o pão até dar sexta-feira. Aí, quando chegava quinta e sexta aquele pão já estava meio duro. Comia pão duro mesmo. E a minha mãe fazia doce de abóbora. Doce de abóbora, doce de banana... Aí, punha junto, e a gente ia comer aquele pão meio duro, passava doce de abóbora, de banana, e ficava gostoso.

A gente ia para a roça e ia para a escola. Voltava da escola, chegava em casa às vezes onze, onze e pouco. Aí, ia para a roça, trabalhar. Ficava lá até escurecer quase. Almoçava. Depois vinha o café das duas e depois ia até escurecer. Trabalhava, trabalhava, trabalhava... Não é fácil não, hein.

Fruta, nossa! Melancia, sabe o que a gente fazia com melancia? A gente nem tirava ela do pé. A gente chegava e dava uma pisada nela, em cima, ela abria e a gente comia o miolo. (risos) Melancia assim fresquinha. $\mathrm{O}$ que a gente fazia para a melancia não esquentar, para a gente comer? A gente pegava, quando ela era bonitona, jogava debaixo do pé de café, com rama e tudo. Aqueles pezões de café grandes eram sombra fresquinha. E depois, na hora que dava vontade de chupar, ia lá, pegava ela e comia a melancia fresquinha. Senão virava um forno. Muitas vezes, os próprios vizinhos roubavam melancia. Quando tinha uma melancia muito bonita, você enterrava ela no chão. Fazia um buraco bem fundo, punha ela, tampava e deixava a raminha assim, como que não tinha nada. Quando a gente ia na roça dos nossos vizinhos, a gente via aquele pé de melancia bonito, assim, aí pegava a rama e ia puxando. $\mathrm{Na}$ hora que não subia, ia ver, estava enterrada. A gente catava aquela melanciona. A gente ia, roubava a deles e eles roubavam a nossa. (risos) Mas é um barato... é incrível. 
No Paraná, nossa, é terra vermelha! Dá de tudo, dá de tudo. Teve vários anos difíceis na vida da gente. Teve fase que não tinha mistura, rapaz. O porco estava magro, pouca galinha. Aí, minha mãe falou: "Vai matar uns pombos para a gente comer porque hoje não tem mistura". Aí, saíamos eu e meu irmão procurando pomba para matar. E a gente achava. Tinha bastante passarinho, pomba - que é Juriti -, matava, trazia em casa, e a minha mãe fazia frito para a gente comer. É, mas era comida fresquinha. (risos) Era caçada na hora.

Então, foi uma época maravilhosa! Tinha aquela geada também, aí matava o cafezal. Aí, vinha a dificuldade. Começava tudo de novo. Ixi! Nossa! Era sem dinheiro, era sacrificado... sacrificado. Até que veio uma geadona, em 1975... mas sempre assim, com muita fé, amor em Deus, e fé, e batalha e luta.

Eu tinha uma irmã que veio morar em Santo André. Porque tinha uns tios meus que moravam no Parque das Nações. A minha irmã veio morar, e ficou morando aqui na Guarani. Eu vim passear aqui e ficar três meses. Aí, o meu cunhado: "Ah, porque que você não pega um servicinho aí, meu?". Isso em 69. E eu trabalhei um pouco de engraxate, em 69. Eu fiquei uns dois meses morando com o meu cunhado aqui. E eu sou de 56. E eu tinha quanto? Treze anos. Era aqui, no começo da Pedro Américo... Pedro Américo, não. Da Valentim, lá embaixo. Morava lá no começo da Valentim. Morava lá na Vila Guarani. É pertinho daquela fábrica Gotis. Mas no comecinho da Valentim mesmo. Onde tem uma escola hoje. Morava aí.

Aí, eles primeiro me puseram trabalho de engraxate. E depois de vender sorvete. Me puseram para vender sorvete. Aí, a minha irmã foi num lugar lá, numa pastelaria em Santo André. Eles estavam precisando de pasteleiro. Ela falou que tinha um irmão que era pasteleiro. E aí, eu cheguei em casa e ela falou:

"Amanhã você vai pegar numa pastelaria".

Eu falei: "Vou fazer o quê?".

"Fazer pastel".

Eu falei: "Mas eu não sei fazer pastel".

E ela falou: "Mas você vai falar para o japonês que sabe fazer. Eu falei que você faz. E ele vai pagar até bem. Você fala que sabe fazer pastel".

Aí, eu falei: "Mas eu não sei".

"Você vai ter que falar que fez, que sabe fazer, que você fazia no Paraná".

Aí, eu cheguei lá no japonês, no dia seguinte. Ela me levou.

"É esse aqui".

"É? Fica aqui".

Aí, a minha irmã foi embora e me largou lá, na pastelaria, na boca quente. O japonês... Eu não tinha feito pastel nunca! A minha irmã falou para ele que eu era profissional.

O japonês falou: "Pode fazer pastel aí".

Eu falei: "Não... porque lá no Paraná eu fazia de um jeito...”, e eu não fazia, né. (risos) A minha irmã falou que eu tinha feito. Se eu falo que era mentira da minha irmã, ele já me mandava embora na hora.

Eu falei: "Não, lá no Paraná eu faço de um jeito. Aqui eu estou vendo que o pastel do senhor é quadrado. O meu lá é diferente. É três cantos. O pastel que eu faço lá no Paraná é diferente. Aqui é quadrado! Eu preciso ver o jeito que você faz pastel quadrado".

Ele falou: "É assim e tal. Essa massa, regula aqui nesse ponto, do cilindrão, limpa o cilindro, você tira a massa, põe aqui na mesa, corta aqui nesses pontos, tal, tal".

Eu falei: “Ah, sim. Pronto, isso eu sei. Só isso aí já está bom”.

Ah, rapaz, eu comecei a fazer pastel... 
Então, e aí a minha irmã me pôs nessa fria. E eu tive que encarar, rapaz. Aí eu vou lá fazer pastel, rapaz... Eu fazendo, fazendo, fazendo... TREZE ANOS, rapaz... TREZE ANOS, sem saber fazer, encarar um cilindrão, fazer o negócio, o pastel, fazendo...

Quando foi à tarde, o cara falou para o japonês: "Esse pastel seu está uma porcaria, japonês! Se você continuar a fazer pastel ruim assim eu nunca mais volto a comer pastel aqui".

Ele falou: "Você não está fazendo pastel que presta! Você... onde se viu!? Eu estou perdendo os fregueses por causa de você!"

Eu falei: "Não, os caras estão reclamando à toa. O pastel está gostoso".

Uma comédia. Aí, chegou de tarde, o cara me mandou embora. Só um dia. (risos)

"Tó aqui o seu dinheiro. Vai embora que eu não quero que você trabalhe mais comigo, não! Você vai acabar com os meus fregueses". (risos)

É mole, rapaz? Aí, cheguei em casa nervoso, falei para a minha irmã: "Olha o que você me fez...".

Ah, rapaz, eu fiz um monte de coisas. Aí, fui embora, chegou na época de eu ir para o Paraná. Ia ter escola, voltei para o Paraná. Eu passei mais 1 ano lá. Quando foi no ano seguinte, começaram as férias lá, o pai: "Vai de novo lá, João. Vai se acostumando. Vai em São Paulo, vai se acostumando porque mais pra frente nós vamos morar em São Paulo". Falei: "Beleza, pai”. Aí, vim em 70.

Aí, o meu cunhado falou: "Você não vai ficar parado aqui, não. Vou arrumar um trampo para você". Falei: "Opa, vamos lá". Aí, eu peguei, e ele foi comigo, na garagem do ônibus, da empresa Humaitá na época. Aí rapaz, arrumou para mim de cobrador. Trabalhei de cobrador. O ônibus vinha até na São Geraldo e voltava. Trabalhei 3 meses de cobrador. Aí, eu precisei ir embora que iam começar as aulas. Pedi a conta e tudo. Mas eu tinha registro na carteira. Eu achei o registro de uma carteira velha minha, e com o registro de cobrador de ônibus. Aqui eu já fiquei conhecendo tudo. Porque aqui em cima só tinha uma estradinha pequenininha que subia para cá. Ruim para subir de carro, mas o asfalto era até lá só. E eu ia conhecendo.

Eu ainda ficava vindo. Vim em 73, vim em 74, acho que em 75 eu não vim. Aí, eu vim em definitivo dia 12 de janeiro de 76. Sempre fazia alguma coisa. Trabalhei de carteiro. Carteiro para entregar cobrança. Pegava cobrança que a turma fazia, ia e entregava numa bicicleta. Fui andando de bicicleta, andando nessas vilas todas aí. Eu lembro do Centreville. Não tinha nada lá. Era só terreno. Então, não conhecia nada. Estou aqui desde 69. Daí eu vim.

Aí, uma vez, em 71, um colega veio junto. E nós descemos a serra de Santos, e eu já tinha quinze anos... Em 73 também desci. A gente desceu de trem. Quando tinha trem. Nós fomos conhecer a praia lá. Chegamos lá, tiramos a roupa, fomos lá, nadamos um pouquinho na água. Dei uma lambidinha para ver se era salgada mesmo a água. (risos) Eu nunca tinha visto o mar...

Em 1975 deu uma geada que queimou tudo lá. Até dentro da tulha, onde guardava o café, tinha cacho de banana, queimou lá dentro. Nos pés, o café queimou até o tronco. Aí, o pai tinha vindo já em 73 e comprou um terreno aqui na Queirós Filho. Até a gente escutava falar das enchentes naquela época, que aqui enchia tudo de água. Falei pro pai: "Você vai lá e compra num lugar bem alto, para a gente não se afogar na enchente lá". "Não, pode deixar, filho. Vou comprar num lugar bem alto". Veio aqui, que tinha um irmão dele que morava no Parque das Nações. Aí, ele encontrou uma imobiliária e falou que queria um lugar alto. E trouxeram para cá, no Guaraciaba. Até na São Geraldo era tudo terra aqui. Era uma estradinha que subia até aqui. 
Ele comprou aqui. Com dificuldade. Ele deu entrada em 73, para terminar de pagar em 80. Era um terreno inteiro. O meu irmão estava aí. Ele deixou o meu irmão pagando. Aí, o meu irmão, em 75, não estava aguentando pagar. Vendeu a metade e falou para o meu pai: "Ó, se não mandar dinheiro eu não vou aguentar pagar nem a outra metade". Aí, deu a geadona em 75 .

No dia 12 de janeiro de 1976 - agora fez... 35 anos - chegou. O pai: "Filho, toma um pouco de dinheiro para ajudar a começar a construir. Quando estiver pronto, a gente vai embora. E a gente vai se virando aqui”. Os coitados ficaram lá, trabalhando por dia e comendo o pão que o diabo amassou, com as minhas irmãs ajudando. Eu vim e meu irmão ia vender. Eu falei: "Não, não. Não vai vender". Com aquele dinheirinho que o pai me trouxe, nós cavamos o terreno, tirando terra, tirando, tirando, tirando, eu comprei os tijolos, e fomos levantando, levantando. Aí, em março, no dia 23 de março de 76, eu entrei na GM. Na General Motors. Comecei a trabalhar. Trabalhava de noite lá, chegava em casa três horas da manhã, dormia até as seis, seis e meia, e aí acordava e vinha lá do Jardim do Estádio - ia a pé até aqui no Guaraciaba, com uma carriolinha, para tirar terra do terreno.

Ficava trabalhando aqui até 1 hora da tarde, sem comer nada. Aí, voltava lá em casa, cansado, chegava lá duas horas da tarde, fazia comida, comia três horas da tarde, e três e pouco eu já saía pra ir para a GM de novo. Entrava quatro e vinte na GM e ia trabalhar. Aí, eu não tinha dinheiro para sair num domingo, pra passear. E foi fazendo, fazendo, até levantar três cômodos aqui dentro.

Em 1 ano a gente levantou três cômodos. Aí, nós arrumamos para o meu pai. Em 1977, ele veio aqui no Riacho Grande. Nós arrumamos para ele. Um dos donos do Hospital Brasil que precisava de um chacreiro. A gente arrumou. Era no Riacho Grande, entrando na Rua Martin Afonso. O cara tinha uma chácara. O meu pai veio tomar conta da chácara e ficou dois anos. Nesses dois anos, a gente fez mais dois cômodos no fundo e aí ele veio morar com a gente, em 1978, no final. Aí, ficou toda a família reunida, deu uma melhorada.

E eu ia sempre construindo. A casa do meu pai, praticamente, foi quase tudo eu que fiz, rebocando, levantando. Trabalhava de noite na fábrica e de dia em casa, e vai, vai e vai. E não sobrava dinheiro nenhum. Eu fiquei cinco, seis anos, sem arrumar uma namorada. Era rapaz sem poder curtir porque eu não tinha dinheiro. Tudo o que eu ganhava na GM... de sábado que eu não trabalhava aqui, eu ia fazer hora extra na GM para poder ganhar dinheiro para pagar os materiais. Foi muito lutado mesmo...

Na mesma época em que eu estava arrumando trabalho na GM, um colega meu falou: "Ô João, vamos comigo na Firestone? Diz-se que estão pegando".

Eu falei: "Vamos". Levei a minha carteira profissional. Mandaram ele sair: "Não, você não". Aí, mandaram eu entrar. O cara me entrevistou e falou: "Não, aqui nós vamos te pegar, sim". E aí mandou o cara me levar: "Ó, leva lá onde ele vai trabalhar". O cara me levou e, rapaz, os caras fazendo pneu, aquele calor desgramado.

Eu falei: "Ah, não. Não gostei daqui, não. Não tem um servicinho, um lugarzinho melhor aqui, não?".

Porque eu já tinha arrumado na GM, né. Eu tinha visitado. A área era boa onde eu ia trabalhar na GM. Aí, ele me levou num lugar para eu limpar máquinas de tecelagem. Você tinha que pôr uma máscara de tanta poeira.

Eu falei: “Ah, pelo amor de Deus! Aqui não. Deus me livre trabalhar num lugar desses".

Ele falou: "Onde que você quer trabalhar, então? Já são dois lugares que você não quer trabalhar".

Aí, a gente tinha passado na tecelagem e estava cheio, tudo roupinha branca, lotado de mulher trabalhando. Eu falei: "No meio daquelas mulheres, não tem um servicinho lá, não?". 
Ele falou: "Vou lá dar uma olhada". Foi lá com o chefe. O chefe pegou e conversou comigo e tal.

Falou: "Aqui a gente está precisando de lubrificador".

"Então eu vou deixar. Você gostou, João?".

"Gostei".

"Eu vou deixar você com ele aí, e você faz entrevista com ele".

Eu fiz entrevista com ele, que falou: "Ó, João, aqui só trabalham quatro homens: Eu, que sou supervisor dessa mulherada, o lubrificador, o mecânico e o eletricista. Só. O resto é tudo mulher. Tem que respeitar. Não pode mexer. Tem que respeitar".

Eu falei: "Não, isso não tem problema nenhum".

E ele falou assim para mim: "O ano que vem, eu vou me aposentar. E quando eu aposento, eu vou apresentar uma pessoa para assumir o meu lugar. Se você trabalhar direitinho e eu for com a sua cara, eu vou apresentar você, porque eu estou gostando de você".

Ele mandou contar a minha história. Eu contei. E falou: "Eu vou apresentar você para ficar no meu lugar, de supervisor". Rapaz!, eu falei: “puxa vida, né, meu!”. E aí eu fiz a entrevista e tudo. E aí, eu cheguei lá no cara que pega, no departamento pessoal, que pega para trabalhar. No RH. Cheguei lá e o cara falou: “E aí, João, dá para começar amanhã?”. E eu já tinha engatilhado... Estava tudo certo na GM. E na GM não precisava fazer exame de sangue. Aí precisava. Aí, ele falou: "Olha...", e eu falei: "Dá".

Ele falou: "Então você tem que fazer exame de sangue amanhã. Tudo bem?".

E eu tinha medo de fazer exame de sangue. Eu falei para ele: "Olha, só que eu falei para o meu pai que eu ia voltar para o Paraná. Assim que eu arrumasse serviço eu ia voltar lá...”.

"Por quê?".

Eu falei: "Porque ele ficou com os documentos, a identidade...".

"Não, não. Eu vou te registrar só com a carteira profissional. Quando tiver um feriado, você vai lá e busca. Você vai trabalhar com a gente. E se tiver problema aí, você vem me avisar que eu vou lá resolver. Mas você vai trabalhar. Eu gostei de você".

$\mathrm{Eu}$ contei a minha história para ele também, que ele me pediu. Ele falou: "Você vai trabalhar com a gente".

Eu falei: "Olha, não. Você me dá um tempo que eu tenho que ir..."

"Vamos fazer o seguinte: você tem 8 dias para ir lá buscar o documento. Eu te seguro a vaga 8 dias. E nesses 8 dias você está assegurado. Aí, você pode trabalhar com a gente".

Eu falei: "Tudo bem".

Aí, eu saí e não voltei nunca mais. Fiquei na GM. Trabalhei 5 anos e meio na GM. Mas me arrependi. Se eu tivesse ficado aí, acho que tinha sido melhor. Tinha pegado um cargo melhor... tinha sido melhor.

A GM é uma empresa boa e tudo. Mas me puseram para trabalhar lá fazendo geladeira. Era uma lã de vidro que coçava pra caramba. Nossa Senhora... Eu fiquei três meses sofrendo lá. Trabalhava pra caramba em linha de geladeira. Depois eu pedi para me tirarem. Acabou a geladeira, me transferiram para outro departamento, que lá fazia banco de carro. Aí, eu pedi para ser soldador, sem saber, sem nada, e o cara me passou para ser soldador sem saber nada. Na hora em que eu comecei a trabalhar, e achei ruim demais, eu falei: "Não quero ser mais soldador". E o cara falou: "Não, agora você já está registrado. Se você não quer mais, então eu vou mandar você embora, mas você tem que ser soldador". Aí, como eu estava precisando para a construção da casa ainda, fiquei de soldador. E aí começou a fazer mal para mim e eu fui transferido para os tornos automáticos. A fumaça, no óleo, subia, e aquilo lá ia para a cabeça. Era aquela solda MIG, e eu perdi muito cabelo na época. Caía muito cabelo, muita química. 
Mas depois veio um facão... com cinco anos e meio que eu estava lá. Deu um facão e mandou quase todo mundo embora, na época. A turma da noite, em que eu estava, mandou todo mundo embora. Pegaram alguns da noite. A maioria tinha sido mandada embora.

Eu já tinha falado com o chefe. Falei: "Olha, eu não estou pedindo para me mandar embora, mas se for para mandar um pai de família, mande eu".

"Por que, João?".

Eu falei: "Ah, fiz um curso de cabeleireiro. E então, se for para mandar um pai de família para ficar na rua, então que mande eu. Mas se não precisar, eu quero continuar aqui".

Ele falou: "Não, tudo bem".

Aí, na hora que mandou embora, mandou pai de família, mandou todo mundo, mandou eu também. Depois, mandou uma cartinha pedindo para voltar. Todos os funcionários que eles acharam bons, pediram para voltar. E eu não voltei mais. Eu fiquei no salão até hoje.

Para mim foi bom, porque eu trabalhei na frente da casa do meu pai e da minha mãe. A minha mãe faleceu faz três anos. Aí, eu convivi muito com a minha mãe. E eu trabalhava na frente, no salão, e subia lá para conversar, para tomar café com o pai e com a mãe, conversar com eles. E ia levando, tendo essa amizade, esse amor junto com a mãe, e curtia a minha mãe, curtia o meu pai. Dinheiro nenhum paga isso.

Curti muito. Minha mãe viveu 82 anos, e fiz de tudo para ela. De tudo, tudo, tudo. E para o meu pai eu faço até hoje. Hoje é o meu dia de pousar lá. Chego lá 1 hora, 2 horas, mas eu vou pousar com ele. A noitada é com ele.

Aí, os meus irmãos foram se casando um, casa outro, casa outro, e eu fiquei o último. Eu falei: "Não, eu vou cuidar dos meus pais na velhice. Vou cuidar". Eu arrumei uma namorada. Foi em 1986, quando eu comecei a namorar a minha ex-mulher. E em 89, eu casei. Eu casei com 33 anos. Mas eu já deixei o meu pai e minha mãe numa boa. Quando eu casei, eu já tinha comprado essa casa aqui. Comprei a casa toda quebrada e derrubada, reformei, e... você pega amor no lugar, né.

Aí, quando eu estava com a minha casa prontinha e arrumada, eu falei: "Não, agora com 33 anos eu vou casar". Aí, eu peguei e casei.

Mas foi em 79 que começou a minha luta na São Geraldo. Em 79. Eu ia na missa, de 76 até 79, normal. Nunca tinha encontrado oportunidade. Em 79, um colega meu me convidou para participar da igreja. "Ô João, vamos participar do Grupo de Jovens aí. Fazer teatrinho e tal".

"Vam'bora".

Aí, eu comecei a participar... Eu fui participar dos teatrinhos e tal. Comecei a me engajar com a turma. Em 80, chegou o padre Mahon*. E ele incentivou. E a gente... Nossa Senhora!... trabalhou muito no Grupo de Jovens. Tinha um Grupo de Jovens de 35, 40 pessoas. E a gente fazia de tudo. Fazia teatrinho, fazia quermesse. O jovem era bom.

Hoje, você vai na igreja, não tem um Grupo de Jovens bom. Grupo de Jovens parece que está morto. O jovem não quer mais nada hoje.

Quem me convidou foi o Lídio. Mas tinha o Murilo, tinha a Marcelina, tinha um monte de gente. Até, na época, eu acho que era o Grupo de Jovens da CUC. Acho que era 'CUC', um Grupo de Jovens. Foi no final de 78, porque em 79 eu comecei a participar das CEBs. Em meados de 79 eu comecei a participar das CEBs.

\footnotetext{
* As pessoas citadas e marcadas com este sinal correspondem a seus nomes reais. A marcação de nomes reais só acontecerá na primeira vez que o nome for citado nesta narrativa. Todos os demais, sem esta marcação, tiveram seus nomes substituídos por outro, fictício. A decisão sobre a manutenção de alguns nomes reais entre os nomes fictícios foi tomada junto com o narrador.
} 
Eu vim assistir um encontro na casa de um vizinho meu aqui em frente. E nesse encontro, eu lembro que eu estava na porta, fora, chegou o padre Mahon... Na época, foi o Perseu que tinha convidado para esse encontro, que ele ia vir. O padre Mahon mandou eu entrar. Eu falei que estava bom.

Ele falou: "Não".

Eu falei: "Está cheio".

Ele falou: "Não, se está cheio, se não cabe você, não cabe eu. Eu vou ficar aqui do seu lado. Ou você entra...".

Eu peguei e entrei, né. Aí, eu fiquei, assisti e tudo, gostei.

Aí, marcamos o próximo encontro na casa do meu pai. Lá, pediram para eu animar.

Eu falei: "Não, eu só vim uma vez".

"Não, você vai animar".

E eu animei. Já era encontro das CEBs. Aí, chegou o padre. Eu não sabia que vinha o padre. Eu nunca tinha animado. Eu estava no meu segundo encontro. Aí, eu estava animando, chegou o padre Mahon. Eu quase desmaiei. Não sabia nem o que falar. Aí, começou. Começou as CEBs.

E o nosso bairro era bem necessitado de asfalto; luz, aí para cima; esgoto, que não tinha; água, que comprava num caminhão na época. Tinha lugares com água, outros lugares não tinha. O ônibus vinha até só na São Geraldo.

Aí, as CEBs foi que deu aquela abertura na minha vida, para participar. Porque a gente sempre falava que as CEBs - as CEBs é 'Comunidades Eclesiais de Base' - é a Igreja que vai até as pessoas, não é as pessoas que vão até a Igreja. É a Igreja que vai na casa da pessoa. Aí, tive a oportunidade de conhecer muitas pessoas, muitas pessoas mesmo!, que através das CEBs, eles começaram a ir para a Igreja. Pessoas que não iam na Igreja. Mas através das CEBs, conhecendo aquele povo, começaram a ir. Como a gente falava aqui - eles sempre ensinavam a gente - que as CEBs é um grupo, não de mãos dadas virado para o lado de dentro, mas de mãos dadas virado para fora, para o povo, aberto para o povo. Era aberto para todo mundo. Era uma chance para aproveitar.

E o padre Mahon dava muita oportunidade para todo mundo. Era um padre aberto. Aquele lá foi enviado por Deus aqui para nós. Depois chegou o Miguel* também, para ajudar, que é outra pessoa maravilhosa. Então, nós fomos caminhando com ele. O Perseu, na época, deu muita força. Depois que o ele entrou na política, ele saiu fora.

E a gente ficou. Aqui na São Geraldo, ficaram muitos grupos. MUITOS GRUPOS. E a gente fez muito abaixo-assinado. No começo... houve a greve geral. Parece que foi em 1980 a greve geral, né. É, foi em 80. E a gente se reuniu na Casa Paroquial. Nós e os seminaristas.

E nós, de madrugada, três horas da manhã, já estávamos reunidos na rua preparando, saindo pra parar os carros. E a gente conseguiu parar bastante. Conseguimos evitar que os ônibus trafegassem, evitar que carros trafegassem. A gente batalhou muito. Tinha aquelas pessoas mais irritadas que queriam tacar pedras nos ônibus, já ir para a violência. E nós nunca deixamos. Nós éramos contra a violência. Nós sempre fomos contra. Nós éramos uma coisa pacífica, para que fosse melhorar a situação do povo.

Veio gente operária, envolvida, a coligação também, as CEBs. E nós engajados nas CEBs. A gente, que tinha força. A gente queria aquela força. Vimos que nós tínhamos necessidade de fazer aquilo lá. De que adiantava nós sermos povo da Igreja e ficarmos de braços cruzados na hora em que o povo mais precisava? Então, mesmo os meus pais não querendo... não queriam. "Não, não vai, não vai, não faz, filho. Você está arrumando para a cabeça. Não vá atrás disso". Eu falei: "Não, eu vou. Eu tenho que ir". Eu estava trabalhando na GM. Lá parou tudo também. 
E não foi só naquela greve geral. Foi a greve geral, depois, outro ano, teve outra greve e nós estávamos envolvidos também. Eu lembro bem que prenderam o padre Mahon na época. Porque o caminhão chegou para entregar o leite, na padaria, e ele não deixou descarregar. Veio o camburão e levou ele preso. Mas os advogados da Diocese já estavam lá para soltar ele. Quando chegou lá, soltaram ele. Então, não ficou nem preso, né. Era para não deixar chegar na padaria. Era para parar tudo mesmo. Era greve geral. Era total.

A gente ia à noite, combinava tudo e tal, certinho. E os materiais que nós íamos precisar. E quando era de manhã, nós combinávamos três horas aqui. Aí, três horas, ia - nem dormia direito -, já voltava lá para a igreja. A gente ficava parando nessa região. Quer dizer, os carros que vinham pela Queirós Filho, a gente não deixava passar por cima. "Pode parar". Não deixava. Os ônibus vinham. Nós furávamos os pneus dos ônibus. Na época, era uma coisa que não era certa, mas que tinha que fazer. Tinha que apelar. Porque os ônibus levavam os trabalhadores para as fábricas. Então nós não deixávamos circular para a turma não ir para a fábrica, para ficar todo mundo em casa. E a gente conseguiu esse objetivo. Quando vinha a polícia, a gente corria e se escondia para a polícia não prender a gente.

Era ditadura militar. Ôôô, era perigoso naquela época. Nossa! Aquela época estava... sério risco nós corríamos. Muito risco. E então... tinha que se doar mesmo. Tinha que ter muita coragem. Não cheguei a ser preso. Mas corri. Corri para não ser preso. (risos) Corri, né. A gente corria. Essa aí foi uma das primeiras lutas.

Eu lembro do padre Otávio, que na época era seminarista. Hoje ele é bispo lá em (local). Ele era super simples na época. Hoje ele já está... né. Eu vou contar aqui e eu quero que fique registrado. Que um dia eu estava na São Geraldo, teve um crisma. Depois de muitos anos... isso está fazendo uns cinco... uns quatro anos atrás. Logo que ele foi bispo. Fazia pouco tempo. Depois que ele foi para (local). Então, ele veio fazer um crisma aqui na São Geraldo. Eu estava há muito tempo sem ver o Otávio. Ele é que era o cara, o braço direito nosso na greve, era o nosso orientador nas CEBs. E eu cheguei nele, ele estava lá dentro da igreja, eu vi ele chegando... Até, naquela época, eu ia ser ministro, eu era Ministro da Eucaristia, já na época.

E eu cheguei nele e falei: “Ô Otávio, tudo bem? Como é que você está?".

E ele falou assim: "É assim que se fala com o bispo?".

Eu falei: "É DOM Otávio. Desculpa. Tudo bem, Dom Otávio?".

Ele falou: “Ah, agora você acertou. É DOM Otávio mesmo. Eu vou bem. E você, João? Você está bem?".

Eu falei: "Eu estou bem, Dom Otávio. Só que você cresceu, né. E eu não. Eu continuo aquele cara que você conheceu. Você lembra... da época das greves? Porque nós lutamos juntos e eu continuo o mesmo cara. Você mudou. Então, me desculpa, tá?".

Aí, eu peguei e saí de perto. E eu fiquei, né... Falei: "Meu Deus, a pessoa da nossa base, um grupo, humilde, no meio de nós...". Porque ele ajudou muito a gente na época. Estava o Ricardinho, o padre Ricardinho também ajudou bastante.

A gente via as necessidades do bairro. Na igreja, os animadores do grupo se reuniam para ver as necessidades do bairro. "Vamos fazer abaixo-assinado". Aí, fazia abaixo-assinado. Eu trazia as folhas para o meu grupo, o outro levava para o grupo dele. Aí, marcava uma audiência lá com o prefeito e a gente levava. Um vereador levava, marcava. A gente levava o negócio, reivindicava, eles demoravam, e vai, vai... Conseguimos trazer a água, e conseguimos, com o abaixo-assinado, trazer o asfalto. Facilitou a vida da turma dessa região toda. Asfalto, ônibus, luz.

A gente pegava abaixo-assinado do grupo, do pessoal. Falava a necessidade deles, no Evangelho. No Evangelho a gente usava: "Hoje nós vamos fazer assim, assim...". A gente lia 
o Evangelho e também rezava o terço. Lia o Evangelho e, em cima do Evangelho, a gente colocava a ação da gente: o que nós tínhamos que fazer. A gente tinha que fazer. A gente rezava o terço. Às vezes lia um livrinho preparado das CEBs. Aí, todo mundo topava, todo mundo dava assinatura, e se fosse para fazer manifestação, fazia.

Nós fomos para a prefeitura. Muitas vezes, lá na prefeitura, o prefeito nos recebia. Outras vezes, a gente ia na Câmara dos Vereadores reivindicar lá. Tinha a quantia de pessoas para entrar. Não podiam entrar todos.

Tem também a reivindicação do tancão na época. Que era para fazer um parque. Logo no começo, nas primeiras gestões do Celso Daniel*, a gente lutou muito para ter um parque lá. Estava morrendo muita gente. Teve muita assinatura, batalhamos, conseguimos fazer esse parque. E depois entrou o prefeito Brandão*, aterrou tudo com lixo. Aterrou tudo, bagunçou tudo. Vai ver o que está hoje lá, a bagunça que está. Aí, virou uma grande precatória da prefeitura. O Celso Daniel estava pagando direitinho. Aí, ele perdeu a eleição e entrou o Brandão, que parou de pagar a precatória. Virou uma bola de neve aquele dinheiro. Hoje a prefeitura já conseguiu quitar. Mas eles queriam pôr lixão, fábrica de asfalto...

A gente brigou muito, muito. Fomos na prefeitura, fizemos manifestação, teve vereador envolvido. Foi uma das últimas lutas que teve, que brigamos muito, para não colocar, para não tampar o tancão nem pôr lixo lá. Eles queriam pôr lixo dentro do tancão. E fábrica de asfalto... Ia virar muita bagunça o nosso bairro. Nós lutamos com pessoas do meio ambiente, que batalharam, que ajudaram, foram para a Câmara. E não conseguiram fazer essa fábrica de piche. É tudo coisa envolvida: prefeito, com empresários... É coisa de muito lucro, mas que ia judiar do nosso bairro.

A luta do ônibus também foi a necessidade, depois que fez o asfalto. A necessidade do transporte era uma necessidade do pessoal, que descia um monte de gente tudo a pé até lá embaixo. Vinha gente do Suíça, de todo lado. Descia tudo a pé. Não tinha ônibus nenhum. Vinha tudo aqui. Aquele MOOONNNTE de gente, que passava aí. Aí, a gente batalhou, batalhou. Conseguimos. Fizemos abaixo-assinado, levamos na prefeitura, e foi para a empresa. Até que nós conseguimos trazer o ônibus aqui, quase mil metros para cima, aqui na Dulce*, aqui perto do Mercadinho Binho. E isso favoreceu meio mundo aqui: da favela Maracanã, da favela Titan, aqui atrás, o povo aqui da Praça Maracanã, o povo aqui da Cláudio de Souza, aqui debaixo. Favoreceu muita gente com essa luta.

Outra luta também: lombada. Pois começou a morrer gente. Atropelamento. Aí, conseguimos essas lombadas que tem aqui para cima da São Geraldo, dos dois lados. Conseguimos essa lombada que tem aqui na subidinha. Aqui morreu uma família, e a gente fez um protesto aí e reuniu todo o povo. E conseguimos fazer a lombada aí também. Parou de morrer gente, através daquelas lombadas, daquela luta.

Outra luta dos ônibus, também, foi que eles começaram a subir os preços. Aí, o padre Mahon foi em cima. Ele coordenava. O padre Mahon era o cabeça, ele era o coordenador nosso, geral. Ele dava as ideias, ele mostrava. Ele dava a visão. Às vezes, a gente precisava da coisa e ele sentia que nós precisávamos. E então, ele dava a visão: "Nós temos que fazer isso, isso, isso e isso".

Então, nós montamos uma sociedade dos usuários de ônibus. Até, na época, o Celso Daniel era o presidente dos usuários. E aí, a gente marcava nos ônibus o número da catraca, marcava o velocímetro - quantos quilômetros rodou. E calculava os valores que deviam ser as passagens. A gente distribuía papel lá na estação, várias vezes, para o passageiro ficar ciente do que estava acontecendo, que estavam cobrando caro demais. Quantas vezes a gente lutou e que não deixamos subir a passagem, e não subia. Ou, também, subia, mas abaixava. Conseguimos baixar. Tudo uma luta criada daqui que ia para lá, para a São Geraldo.

As CEBs pegou em outros lugares também, fortalecida. Tinha na Vila Luzita. Fortaleceu muito. Então, foi uma luta muito boa a dos ônibus. Outra vez que quiseram 
prender o padre Mahon também, pegaram ele no ônibus, anotando. Virou, mexeu, o padre Mahon estava no jornal. (risos) Isso foi uma das lutas.

Agora, outras lutas aconteceram lá no Centreville, na invasão. A Igreja nunca incentivou ninguém. A Igreja sempre viu que cada um precisa ter a sua morada, e morada digna. Mas nunca incentivou ninguém a entrar na casa de outro, de nada. Mas outras sociedades que teve por aí, um pessoal aí, invadiu o Centreville. E a polícia ia descer o pau no povo, expulsar com cavalo, com tropa, com tudo. A Igreja entrou no meio. Aí, nós entramos na luta. Um pessoal fortalecido com as CEBs. A gente entrou. E ia em reuniões. Aí, o padre Mahon fazia reuniões com o governador. Ia segurando aquele povo. $\mathrm{Na}$ época, eu lembro do Franco Montoro*, que foi bom naquela época. Ele organizou, segurou o pessoal. Chegou um belo dia lá, a turma, aquele outro grupo que invadiu, achou que era o momento de tirar o padre, não aceitar mais o padre lá. Aí, não aceitaram mais o padre Mahon. Não aceitaram e nós nos recolhemos. O padre Mahon saiu, a gente saiu tudo. Ficaram eles brigando. E ia despejar mesmo.

Então, correram lá com o governador - acho que era o Montoro na época, se eu não me engano - e o governador falou que conversava só com o padre Mahon, e que não tinha conversa com eles. O único que ele recebia era o padre Mahon. Eles não. Com o padre Mahon tinha negócio. Aí, vieram, tudo de cabeça baixa, pedir desculpa para o padre Mahon e pedir para que ele voltasse. Foi tudo passado dessa forma para mim. Aí, o padre Mahon foi lá e negociou. E segurou. O povo está até hoje lá no Centreville. Segurou... O Montoro foi muito bom na época. Segurou o povo aí, né. Olha só, a turma é que nem Judas, né. Fizeram que nem Jesus Cristo. Jesus Cristo veio para salvar a humanidade e foi crucificado. E o Mahon lá para ajudar esse povo, apoiando esse povo, e expulsaram ele. Foi a mesma coisa de Jesus Cristo! A mesma coisa! Mesma coisa... Expulsaram ele... Aí, eles é que vieram... Vieram e se renderam ao padre Mahon. Pediram perdão e pediram para que fosse... E o padre Mahon com todo o carinho... O padre Mahon é muito bom, né! Ele é o mestre.

A gente ia nas assembléias. E o povo: "Ah, essa casa aqui... Eles pegaram do nosso dinheiro. Nós temos direito. Está aqui abandonado". E estava abandonada mesmo. "Está destruindo. Vamos ficar resistindo, vamos. É nosso... A nossa família, os nossos filhos vão ter moradia digna. Vamos lutar para a gente conseguir, para ficar”. E a turma, cada um pegou a sua casa. Depois que estava lá dentro, o padre também não queria que a polícia fosse lá e arrebentasse as pessoas, as famílias, batendo em criança. Não. Aí, a Igreja entrou no meio: para tentar negociar. E olha que conseguiu negociar.

Aí, teve a invasão do Jardim Robru, em São Paulo. Que daqui da São Geraldo foram convidados, para ir lá, e fomos eu, o padre Mahon, a Marcelina - que era do Grupo de Jovens também, e eu era do Grupo de Jovens e das CEBs, ia representando CEBs -, e o padre Miguel. Chegamos lá de madrugada. De madrugada não, acho que era meia-noite.

E o pessoal lá disse: "Se trouxe dinheiro para nós, tudo bem. Senão, não vem aqui, não". Isso disse a turma que invadiu.

"Não, nós somos da Igreja".

"Mas trouxeram as coisas para a gente comer? Trouxeram dinheiro? Não? Então vêm fazer o quê aqui?".

O padre Mahon: "É que nós viemos apoiar vocês. Eu quero conversar com o organizador. Eu quero estar do lado de vocês. Nós somos da Igreja. E nós estamos aqui para que a polícia não massacre ninguém". Porque naquela época era a ditadura, né. Naquela época era... não comparo com hoje, não. Desciam o pau mesmo.

E vai, vai, vai, passamos lá, negociamos com o pessoal. Aceitaram que o padre Mahon ficasse. O padre Mahon tinha cidadania brasileira. O padre Miguel ainda não tinha. Então, se a polícia pegasse o padre Miguel, na época, ele era expulso do país. Aí, o padre Mahon pediu que nós viéssemos embora e ele ficasse lá. Nós viemos embora. Viemos eu e o padre Miguel, 
com o carro da Marcelina, que era um fusca, e viemos nós três embora. E nós três nos perdemos no meio do caminho. A gente não conhecia nada. Lá no Jardim Robru, em São Paulo. A gente não conhecia nada, e era de madrugada. Chegamos aqui. Demorou umas duas horas.

O padre Mahon negociou com o pessoal lá, com polícia, com tudo. Eu sei que a turma parece que conseguiu ficar lá, na época. Aqui teve também. Depois de um tempo teve a invasão do Inocoop, aqui no Jardim do Estádio, Jardim Alvorada. Estava muito tempo desocupado e a turma invadiu lá. Aí, vão os padres daqui também. Os representantes daqui vão lá negociar. E negociam pacificamente. E negociavam um dia, noutro dia pousavam. $\mathrm{O}$ povo da Igreja ia lá apoiar. Apoiar o povo que já estava lá. Mas nunca apoiar para invadir. Apoiar quem já estava lá dentro, para que a turma respeitasse aquele povo, que era família trabalhadora, pessoas que trabalhavam, que precisavam de moradia. E teve êxito também. Ficaram lá. E lá se acertaram, negociaram para a compra e tudo.

E tem lá as lutas dos bairros. As lutas do bairro, a gente sempre esteve infiltrado, lutando para a melhoria, lutando... Vai conseguindo melhoria, melhoria, melhoria, melhoria... que todo mundo vai tendo a sua água, chegando nas suas torneiras; vai tendo a sua energia; vai tendo asfalto na porta de casa; vai melhorando as suas casinhas; quer dizer, vai acabando um pouco aquela reivindicação, né. Aí, os grupos de CEBS foram indo, foram indo... e foram parando aquelas lutas. E então, foi enfraquecendo. Hoje não se fala mais 'CEBs' nos grupos. Fala-se 'Grupo de Rua'. Mas é a verdadeira 'Comunidade Eclesial de Base', que é fruto daquela época ainda.

Hoje tem aqui na São Geraldo mais de 20 grupos funcionando. Tem grupos maravilhosos. Eu até dei um tempo agora. Eu fiquei 1 ano mais afastado, mas estou com as minhas atividades na Igreja. Eu estou lá de Ministro da Eucaristia, sou Ministro das Exéquias ainda, trabalho na Acolhida da igreja, estou no Apostolado da Oração. Às vezes, eu falto porque eu saio tarde demais do salão. Tem muita gente. Eu estou no Conselho Administrativo da Igreja São Geraldo também. E vou lutando. Quando eu puder ir no Grupo de Rua - que é a antiga CEBs -, eu vou. Mas eu fui animador muitos e muitos anos. Muitos. Formei uma média de três a quatro grupos fortes. Formados, que eu formei, hoje tem dois grupos fortes trabalhando.

A primeira vez que eu animei, ah!, eu ficava apavorado, né. Ficava falando, falando. E ficava perguntando para as pessoas o que elas achavam do Evangelho... e torcendo para acabar logo, o quanto antes. (risos) Estava apavorado. Aí, eu pedia: "Não é mesmo?". Falava para o fulano, o animador, que era o Perseu. E o Perseu falava tal, tal, tal. E me falava: "Ah, deu para a turma entender o Evangelho". Foi uma coisa gostosa que a gente teve.

Quantas vezes que, na casa, lotava a sala, a cozinha, trinta, quarenta, cinqüenta pessoas! Quantas vezes teve cinqüenta pessoas numa casa, reunidos, rezando. E vendo o que eram as CEBs, as Comunidades Eclesiais de Base. Ajudou muitas pessoas, ajudou muita gente.

Eu fui me descobrindo, descobrindo dentro de mim, outra coisa, outra realidade. Que a gente, sem a participação, sem essa união, você é católico, vai na igreja, mas tem a cabeça fechada ainda. A partir das CEBs...

$\mathrm{Na}$ época, a CEBs revolucionou muito a minha vida. Eu aprendi muita coisa. Sempre a gente foi humilde, mas aprendi a viver mais em prol dos outros. A ter mais ligação. Porque na época, mesmo você não tendo a ver com nada, mas você queria ajudar alguém. Você precisava fazer para alguém. 
E eu comecei a participar dos grandes Encontrões que tinha. Eu fui em Encontrão em Piracicaba, representando aqui a região Leste das CEBs. Pousei, e ficamos três dias lá. Em grandes encontros que teve, e outros encontros que eu fui, você vai aprendendo a desenvolver a abertura, como a gente é importante no meio do povo, a massa, como é importante. E a nossa reivindicação, a nossa luta, a força que tem.

Às vezes, a gente que luta, não percebe. Mas a pessoa que luta, quando você se infiltra no meio, você vai ver que tem grande força, que apavora as autoridades. Apavora a autoridade. Eles têm medo quando a gente se reúne, se organiza. Porque, com certeza, vai bater de frente com eles e eles não vão fazer a cabeça da gente fácil. É muito difícil fazer assim. A gente não quer nada contra eles. A gente apenas reivindica o direito que a gente tem. $\mathrm{O}$ direito que é tirado da gente, que a gente paga impostos, que a gente luta no dia-a-dia, e a gente não tem aquele direito, né. A gente, muitas vezes, é explorado.

Então, a gente vai aprendendo, nas Comunidades Eclesiais de Base, a não ser explorado, a viver uma vida digna, a viver não só para a gente, mas para o seu próximo, para a pessoa que está do lado. Mesmo eu tendo a água na minha torneira, eu tendo luz na minha casa, eu tendo asfalto na minha porta, eu tendo tudo organizadinho, mas tem aquele meu irmão que está lá na favela, que não tem esgoto - está correndo a céu aberto -, não tem um encanamento, não tem nada. E está tudo jogado lá, aquele meu irmão está necessitado. Então, eu tenho que estar do lado dele, reivindicando para ele.

Quantas vezes, aqui na favela Maracanã, a gente foi na prefeitura conversar com o Brandão. Na época, recebeu a gente muito bem. E eles vinham analisar. E foi apertando, apertando, até que eles canalizaram. Mas eles não fazem na hora. Mas mordendo, batendo, batendo, batendo sempre de frente, a gente acaba conseguindo alguma coisa. Agora, se ficar de braços cruzados não dá.

Então, são vários grupos. Várias sementinhas distribuídas no meio do povo. E aquele povo que participava sentia necessidades. E não estava tendo esgoto, a água era precária, o esgoto correndo a céu aberto... Então, eles reivindicavam, eles pediam. E a gente fazia abaixoassinado e levava. Levava até a prefeitura. Então, foram muitos e muitos anos de reivindicação. Ele não atendeu na hora. Mas brigando, quatro ou cinco anos, conseguia.

No grupo de CEBs, a gente ou fazia o terço ou já fazia a parte do livrinho, sem o terço. Aí, tinha o Evangelho. Quando era preparado o livrinho, tinha o Evangelho. Tinha a História da Vida - às vezes o livrinho estava preparado com a vida da gente hoje -, e a história do Evangelho, ligada à nossa vida hoje. Aí, deixava aberto para as pessoas. Porque o nosso lema era assim: que todos falassem. Não era importante que eu ficasse falando. Importante era quando eu pedia à pessoa, que quisesse falar sobre aquele problema, e ele colocava: "Bom, na minha família acontece um caso parecido com esse". A gente fazia ligação daquele Fato da Vida com o Evangelho. Aí, o outro colocava: "No nosso bairro, o que pede aí no Evangelho, está pedindo no nosso bairro. Nós estamos precisando. Está precisando sermos unidos. Nós precisamos nos organizar".

Às vezes, juntava para ajudar a cobrir barraco de fulano, ou juntar um material para ele. Porque ele tinha que ter participação também naquilo que nós fazíamos. E então, na nossa reunião das CEBs, no nosso encontro, nós nunca deixávamos sem a abertura da oração, nunca deixávamos sem o Evangelho. Muitas vezes tinha o terço. Uma reunião era uma hora e meia. Tinha reunião que ultrapassava uma hora e meia. E nós nunca deixávamos que houvesse conflito.

No começo, um discordava da ideia do outro. Às vezes, um não concordava e do outro lado dizia: "Eu não concordo!". É uma palavra pesada dizer “eu não concordo". A gente não aceitava essa palavra: "eu não concordo". Mas a gente colocava de uma forma que a pessoa que colocou já ia ver que tinha penado nas palavras que falou e que não devia ter falado. Você 
não precisava falar para não queimar aquela pessoa do encontro. Você valorizava, colocava de uma forma COM CARINHO para que aquela pessoa continuasse participando. Para que aquela pessoa não saísse falando mal, que ela continuasse participando, e que ela continuasse ajudando. Então, a gente sempre colocou assim: não deixar conflito. Deixar o diálogo, conversar um com o outro, mas sem conflito. Porque o conflito tem a divisão, e a divisão não é boa. Destrói, né. Destrói e o grupo se apaga. Na hora em que nós víamos que tinha esse negócio, eu entrava no meio: "Não, pára aí. Opa. Vamos botar o Evangelho aqui. Vamos começar o Evangelho: é aqui, é aqui... você tem a sua forma de pensar, o fulano aqui tem a dele, cada um repensa. Todo o tipo de pensar é positivo. Então vamos unir a nossa força. Vamos tentar: NÓS lutarmos para conseguir fazer algo para isso e para aquilo".

Então, o animador tem que ter um grande equilíbrio para que, na hora, a gente entrasse no meio e preparasse. A gente fala: "Vamos fazer passos concretos". E sempre, de um encontro para o outro, a gente procurava fazer um fato concreto. Tinha pessoas necessitadas. Quanta sacolada que foi feita... Quantos mantimentos que foram doados. Cada um levava o seu quilinho, fazia para aquela pessoa, trazia as coisas de primeira necessidade. Para a pessoa que realmente precisava.

Olha, vou falar a verdade para você: eu aprendi muito, aprendi muito, aprendi muito. Hoje, eu tenho a minha participação na Igreja, mas sinto muita falta dessa luta. Sinto muita falta, muita falta mesmo. Porque hoje não é nem sombra do que foi no passado. Hoje, a gente não vive nem sombra. Hoje, a gente está num país do primeiro mundo. As igrejas lá vivem de braços cruzados. E aqui, a gente, aos poucos, está cruzando os braços. Infelizmente. Está cruzando os braços aos poucos. Muitas vezes eu vejo que a Igreja precisava arregaçar as mangas, fazer algo. E muitas vezes a gente tampa, faz de conta que não enxerga. Por isso, às vezes tem momentos que dá tristeza. O que a gente viveu, dá saudade.

Dá saudade do que viveu porque a gente deu muito fruto, muita luta... muita garra. E a gente sentiu muito quando o padre Mahon saiu. Que o padre Mahon... E o padre Miguel também, deu muita força. E a gente sentiu muita, muita falta. Que o padre, hoje ele está aqui, amanhã ele está lá. E aqui eles agüentaram bastante, o padre Miguel e o padre Mahon. Hoje está o Félix*. O Félix também é um grande animador. Mas não tem a força que o padre Mahon tinha. O Félix, hoje, já encontrou o nosso bairro bem urbanizado. As favelas, a maioria delas, tudo urbanizadas. Já tem esgoto, tem vielas, tem iluminação, tem as lombadas na rua, tem o asfalto, tem tudo. Então, quer dizer, é menos campo de trabalho. Hoje está com menos campo. Na época, nós tínhamos tudo para fazer. E na época foi muito boa a nossa luta, foi muita batalha, eu me descobri muito.

A gente ainda tinha um grande Grupo de Jovens, que pedia nas casas para fazer festa, para tentar melhorar a nossa igreja, fazer o salão! Era unido! Um grupo de mais de trinta jovens! Tudo animado! Não precisava adular ninguém. $\mathrm{O}$ nosso grupo não era fechado, era aberto para todos. Nós não admitíamos panelinha. Via panelinha, a gente entrava no meio e destruía a panelinha. E não tinha assim: "esse é o coordenador geral, ele que é o mandachuva". A cada encontro nós nomeávamos um coordenador daquele encontro. Então, todos tinham oportunidade de ser coordenador.

A gente tinha direção. Tinha uns quatro ou cinco que pensavam um pouco mais, que ajudavam a organizar. Mas a cada encontro nomeava um coordenador. Aquele que nem pensava que tinha condições de ser coordenador...: "Hoje você vai coordenar o nosso encontro, o nosso grupo, o nosso passeio". Foram tantos. "Então, o João é o responsável pelo passeio, responsável para isso". Dava trabalho para eles. Dava trabalho. Fazia teatros. Eram jovens da Juventude Geração, mas jovens infiltrados nas CEBs também. A maioria deles participava. A maioria tinha trabalho nas CEBs. A maioria. Então, tinha muita força. Muita força. De que jeito acabou esse nosso Grupo de Jovens? Deu, mais ou menos, acho que doze 
ou treze casamentos desse Grupo de Jovens. Casou, corre. Casou, corre. (risos) Foi casando, casando...

Minha ex-esposa não participava. E eu falei para ela: "Quer namorar comigo? Eu tenho isso, isso, isso e isso. Você vai participar? Se você falar que não aceita, então não quero".

"Não, eu aceito". E ela começou a participar do Grupo de Jovens, e tudo. Ela participava comigo. Aí, nós casamos no Grupo de Jovens lá. E foi tudo bem.

Teve separação por causa dela. Se fosse a minha estrutura, que eu tenho, jamais teria separado, porque eu dou muito valor para a família. Eu sou muito família. Já falando de mim, não mais das CEBs... Quantas vezes que ela queria sair daqui, achava que esse bairro não era legal. Eu falei: "Não, vamos ficar aqui. A gente se estruturou aqui, a gente tem a comunidade aqui, tem os meus pais aqui", que eu falei também que tinha... Eu tinha que ficar ao lado dos meus pais, acompanhar eles na velhice. Ela falou que topava, que não tinha problema. "Você lembra?". "É, mas se você não mudar daqui, um dia eu te largo". Aí foi, foi, foi e me largou. Mas eu não mudei. Eu continuo firme na Igreja. O padre Félix diz que tem uma lei na Igreja eu não sei -, que se eu casar com outra mulher, eu não posso mais assumir de ministro. A Igreja me expulsa de ministro.

Por outro lado, o padre Mahon falou: "João, por que você não namora?".

$\mathrm{Eu}$ falei: "Ah, o padre Félix falou que eu não posso, porque senão me expulsam de ministro. Eu gosto muito de servir a Igreja. Mas eu estou namorando escondido".

O padre Mahon falou: "Você tem direito de namorar. Você honrou com o juramento que você fez na Igreja. Você não quebrou o seu juramento. Você não quebrou. Você não estaria com ela até hoje se ela não tivesse te largado?".

Eu falei: "Lógico, com todo o amor. Estaria com a minha família até hoje".

"Então, você tem direito de arrumar uma pessoa e ser feliz. Pode namorar, sim", o padre Mahon falou.

E aí, eu arrumei namorada. (risos) Se quiser me expulsar, eu vou sentir muito. Eu falei: "Nossa Senhora". A minha mulher participava da Igreja, do Coral, de tudo. Aí, nasceu a minha filha, o meu filho, tudo, e ela participava. Quando nasceu a minha filha, ela se afastou para ter ela, para cuidar dela, e nunca mais regressou. Ela queria me afastar também. Eu jamais... eu jamais... E ela falou, na separação, que o ponto principal da separação... colocou a Igreja como número um. Quer dizer, e eu, indo na Igreja, eu perdi minha mulher por causa da Igreja.

Eu sempre me dediquei para a Igreja. Perdi minha mulher... E a Igreja, depois, quer tomar uma coisa que eu gosto, que é o ministério... Porque eu não posso mais arrumar outra mulher. E eu não fiz nada para perder essa mulher. Eu fiz de tudo para ela, eu dava de tudo, fazia, batalhava, uma família, tratava com carinho. E ela pegou e me deixou. E eu vou ser sacrificado a viver sem uma pessoa do meu lado? A minha vocação é ter família, é ter esposa e filhos. Não foi vocação para religioso, assim, para ser padre. Senão eu tinha feito os meus votos de padre. Tinha me ordenado, tinha lutado. Mas a minha vocação é seguir a Igreja com uma família.

A minha vocação é estar na Igreja e ter família. A partir do momento em que a família me proibir de ir na Igreja, então eu perco família, mas a Igreja eu não perco. Porque eu acho que Deus deu isso para mim, e isso eu vou levar sempre. É um presente que eu tenho de Deus: é a vocação de seguir a Igreja, de levar o Evangelho a muitas pessoas que ainda não têm.

$\mathrm{Eu}$ estou meio apagadão ultimamente, mas se eu arrumasse uma mulher que me ajudasse na Igreja, eu voltaria com tudo de novo. Eu estou participando, não me afasto da Igreja de jeito nenhum. Foi um BAQUE muito grande a minha separação. E eu falo da união para o povo, eu transmito coisas boas, e de repente uma separação. Naquilo que eu tenho que dar exemplo está acontecendo dentro da minha casa. E eu sempre falei para o pessoal: "Eu 
venho na igreja, mas eu nunca saí de casa de mal com a minha mulher para vir. Porque se for para eu vir na igreja e sair de mal com ela, eu não venho. Então, não estou assumindo o meu papel".

Então, eu sempre tive de boa. Levei a coordenação com a minha ex-mulher, e eu pegava trabalho na missa da manhã, pegava na missa da tarde. Num domingo. No outro domingo eu não pegava nada para ir passear com ela. Ia para Santos com ela, levava para passear com eles. Aí, no outro domingo era envolvido na igreja. Nas duas missas. Envolvido e tudo, e no meio da semana envolvido. Mas no domingo seguinte, pegava os meus filhos e minha mulher e ia passear, direto. Fui fazendo assim, sabe? Um domingo para a minha família, um domingo para a Igreja. Eu ia controlando. Porque não adianta nada eu ficar só dentro da igreja e viver um abismo dentro da minha casa.

Então, eu achava assim: é importante que eu participe, mas é importante que eu viva feliz com a minha família. Eu vou levar o exemplo para as pessoas lá fora do que eu vivo dentro de casa com a minha família. Um bom exemplo.

De repente, eu levo uma rasteira. Deu uma quebrada grande, sabe. E inclusive, muitas pessoas da Igreja me ajudaram, os padres me ajudaram bastante, mas a vida da gente, né... Eu senti um baque... E nesse baque que eu senti, eu senti momentos sozinhos aqui. Momentos que eu senti que faltaram pessoas para vir conversar comigo. $\mathrm{O}$ tanto que eu fui conversar na casa das outras pessoas, né! A gente vai na casa das pessoas, você vive com os problemas das pessoas. É marido se separando, a mulher se separando, a mulher que o marido foi embora para o Norte, largou, passando necessidades... E você está lá, atuando, ajudando. Nos grupos, você fica sabendo do problema das pessoas. O problema da vizinhança, tudo. É porque você vai na 'Igreja que vai até as casas das pessoas'. Você vai saber dos problemas das pessoas, vai conversar, visita... Fazíamos muitas visitas na época e... então você procura confortar as pessoas.

Mas no serviço, no salão, a turma vinha e se abria também. Você conversa, com diálogo, com paciência, e tal e tal, e conversa e conversa... E depois você se sente vivendo o que aquela pessoa viveu, passando por aquele problema daquelas pessoas que você ajudou. Você passando pela mesma situação, ou pior, levando aquela bordoada sem esperar. "Não te quero mais. Estou indo". E é uma sensação ruim. E, às vezes, você ficava em casa, não vinha UM da Igreja para conversar com você. Não vinha um... Se você quisesse, tinha que ir atrás. E todo mundo sabendo que você estava se separando, separado, e não vinha um. RARO vir uma pessoa aqui. Raro. Dá para contar nos dedos. Que vinha trazer um pouco de conforto. Mas eu ia buscar. Eu... eu não ficava fechado também. Eu ia buscar. Eu ia atrás. Ia atrás do padre Miguel, do padre Nelson*...

O padre Nelson é uma pessoa maravilhosa! Não sei se você conheceu ele. O padre Nelson, hoje, está no México. Um dos Filhos da Caridade. Pessoa maravilhosa! O padre Miguel, o padre Mahon, o Félix - eu conversava com o Félix -, então, cada um apoiou da forma que pôde. Eles me apoiavam, me fortaleciam. Mas eu nunca abaixei a cabeça, não. Eu sempre de cabeça levantada e participando. Não é por isso, não.

As CEBs já estavam perdendo um pouco da identidade na época. Foi em 2006. As CEBs já estavam perdendo o nome, virando 'Grupo de Rua', que eu nunca gostei disso, eu sempre falava "é CEBs". Hoje é CEBs, mas CEBs mais enfraquecida. Faz ação ainda hoje, tem ações. Mas elas são mais lentas, mais devagar, menos coisas. Presta aquela assistência para a pessoa necessitada. Faz abaixo-assinado... da Diocese, não é nem do bairro. São coisas $\operatorname{assim...~}$

Eu achava, assim, que era para vir alguém me visitar e conversar. Para saber como eu estou: se eu estou legal ou estou mal. "Você está morando sozinho. Como você está?". Era para vir conversar com você. Precisava de um apoio. Eu senti uma frieza nessa parte. Eu falei: 
"Caramba, como a gente se sente só. Tem momento que a gente se sente só, mas eu não vou ficar só, não. Eu vou dar a volta por cima. Eu não vou abaixar a cabeça. Eu vou pra cima”.

Na Igreja, atuando, nos grupos, mesmo com vontade de chorar, mas estava sorrindo. Eu sentia vontade de chorar, mas eu estava sorrindo.

Tenho dois filhos. Esses filhos foram tirados de mim. Eu peço a Deus que minha exesposa seja feliz. Eu sempre desejei o bem para ela. Porque ela sendo feliz, os meus filhos vão viver felizes também. Eu amo muito os meus filhos. Então, eu estou vivendo feliz, pô. Estou namorando, estou vivendo um momento feliz, estou dançando, fazendo aula de dança, e estou cuidando do meu pai. A minha mãe faleceu, infelizmente. Mas é uma coisa de Deus. Era o momento. Ela viveu o que tinha que viver. O que Deus tinha dado a permissão para viver aqui na terra, ela viveu com dignidade, com amor.

Ela era firme na Igreja, participava dos grupos de CEBs, andava comigo. Minha mãe era sempre atuante. Sempre estava comigo. Então, nós dois éramos, da casa, os mais rezadores. E a gente, participando das CEBs, indo nos grupos, chegava dez horas em casa, dez e meia. E muita gente criticava, falava que eu estava atrás de mulherada, falando que estava atrás disso, atrás daquilo. O que não participa igual, mete a lenha. E eu sempre lembrava daquele Evangelho da bem-aventurança. Que Jesus falava: "Bem aventurado seja aquele que é injuriado e que é difamado por minha causa. Você terá o seu lugar, você será recompensado". Eu lembrava sempre disso aí.

Quando a minha mulher não queria que eu fosse mais na Igreja, eu lembrava da mulher do moinho: "Vai ter duas mulheres no moinho, uma vai ser levada, a outra vai ficar". Eu falei: "Eu vou lutar para que...". É lógico, eu queria que o dia em que Deus buscasse, fossem os dois. Mas não é por causa de uma pessoa que vai fazer a minha cabeça de tirar do rumo de Deus, do meu caminho. E também eu não sou nenhum santo, eu sou pecador... Às vezes, eu faço coisas que eu acho que não é nem permitido. Não estou casado, estou com a namorada, e a gente tem as nossas relações. A Igreja às vezes não permite, mas eu sou um filho de Deus e preciso disso. E fazer o quê. O que a vida está oferecendo para mim é isso. E eu procuro viver numa boa, na dignidade, procurando fazer o que eu posso. A gente faz uma pequena coisa. (risos)

Uma vez por mês a gente se reúne, eu e um outro cabeleireiro aqui embaixo, o Tio Gil*, e agora chamei outro, o Juninho*, e a gente está indo na Igreja Santa Gema. É lá perto da Petroquímica. É aquele subidão da Petroquímica. Naquela Igreja lá, eles servem por dia, 100, 150 ou 200 refeições, para esse pessoal de rua, o povo de rua. Eles vão lá comer. Café da manhã e almoço todo dia. E lá tem tanque, que eles lavam a roupa deles, banheiro que eles tomam banho, ficam limpinhos. Então, uma vez a cada quarenta dias, mais ou menos, nós estamos indo lá cortar cabelo.

Nós chegamos em três cabeleireiros. Nós começamos a cortar cabelo lá oito, oito e vinte. Ficamos cortando até meio dia, meio dia e vinte. A gente corta lá uns 70 cortes de cabelo, passa a máquina na barba deles, dá um tratinho, trata com carinho todo eles, tudo direitinho. Ficam tudo felizes. Eles ficam tudo com o cabelinho cortadinho. É uma coisinha, né... É uma areinha num imenso mar, numa imensa praia. É um grãozinho de areia que a gente está colocando, está juntando. Eu sei que é pouca coisa, mas a gente precisa fazer mais coisas assim... bem mais coisas...

A coisa importante que a gente vem fazer é a visita para as pessoas. Quanta gente que precisa hoje de visitas... É uma coisa que as CEBs priorizam muito: fazer visita para o doente, para a pessoa desesperada. Pessoas que talvez não estão precisando de arroz e feijão, mas estão precisando de um alimento espiritual. Que estão na beira de sofrer um enfarte, na beira de se matar, de tomar um veneno. Uma palavra amiga ajuda. Numa doença, você leva conforto. E eu levo, todo domingo, comunhão para dois, três doentes. Na hora que eu chego é 
uma felicidade. Me abraçam, me beijam, é aquela alegria. Eu chego brincando... A gente sempre passa alegria para as pessoas.

Mesmo você vendo que aquela pessoa talvez não tenha recuperação, mas você fala que Deus é o médico dos médicos, e que ele pode ficar bom a qualquer momento, voltar na ativa de novo, voltar feliz. Você larga a pessoa lá com alto astral... Isso é importante a gente fazer.

A gente vai levando. Vamos ver o que vai ser daqui para a frente. Eu espero é que possa virar prática, porque as CEBs podem atuar mais. Podem atuar mais. Mas graças a Deus, as coisas estão melhorando bastante. Do que a gente viveu há anos atrás, nos anos 79, 80, 81, 82, 83, aquela CEBs atuou muito. Atuou muito. E foi MUITO bom. Teve muitos frutos. Muitos, muitos, muitos frutos. Foi muito bom. Outra coisa: é juntar o pessoal para se reunir na Igreja. Quantas pessoas que hoje estão lá dentro da Igreja e que foram descobertas no grupo das CEBs.

Eu sei que para eu ficar feliz, rapaz, é a pessoa perguntar para uma mulher na Igreja: "Faz tempo que participa aqui, né?".

"Ah, faz".

"Como você começou a participar?"

"Ah, você nem acredita. Eu fui num grupo lá e quem era o animador era o João Cabeleireiro. E ele convidou para participar, para ajudar a animar o grupo". aquilo".

Porque eu sempre convidava as pessoas: "Ó, faz a leitura. Você faz isso. Você faz

Dar tarefas para as pessoas. Eu era o animador do grupo. Eu sou animador do grupo, mas eu chegava lá:

"Hoje você vai...".

"Ah, não...".

"Não, você tem condições".

“Ah, não...".

"Faz o seguinte: você anima e eu vou ficar do lado, eu vou ficar te dando apoio".

E aquela pessoa animava tudo com medo, igual aconteceu comigo.

Então você dava aquela abertura para a pessoa participar. E aquela pessoa ia ficando incumbida, ia animando outros encontros, e quando via aquela pessoa estava lá na igreja fazendo uma leitura. Aí, a gente convidava: "Vamos participar da igreja. Lá tem o Coral, tem o grupo de liturgia... você sabe como é que é. Vamos lá...". E a pessoa está dentro da Igreja. Aí, deu uns tempos, aquela pessoa está lá dando uma força.

Aí, convidava o fulano.

"Ajuda aí....".

"Não, mas eu não sei..."

"Não, mas aqui não tem ninguém inteligente. Somos todos iguais, aqui ninguém sabe nada".

Porque diante de Deus, a sabedoria da pessoa analfabeta dá lição na gente que sabe ler e escrever. Um analfabeto dá lição numa pessoa que tem faculdade. Dá lição para a gente. Porque as coisas de Deus não são iguais as coisas dos homens. São diferentes. Então, todos nós temos condição de animar, sim.

Então, cada dia eu deixava um animar. E através dessa animação, a pessoa pegava aquela vocação e ia em frente. Eu deixei animadores nos grupos. Quando o grupo estava bom, eu deixava ele comandar. De vez em quando, eu ia visitar. Aí, ia em outro, formava outro. Formamos uns três, quatro grupos. Foi muito bom. Muita coisa plantada. (risos) Você vê. Então, você fica feliz.

Quando falam assim: "Ah, o João que pegou no meu pé para participar. Ele pegou no meu pé e eu comecei a animar grupo, e hoje eu estou aqui na Igreja." E é ministro lá na igreja. Então, você fica feliz. É aquela pessoa que não desistiu. Pessoa birrenta mesmo que está lá 
participando até hoje na Igreja, está nas comunidades... nos Grupos de Rua - que são as Comunidades Eclesiais de Base, as CEBs - está indo, atuante até hoje. Hoje, você vai em grupo aí, chega lá tem vinte pessoas. Está com aquele povão reunido, numa cidade! Igual hoje, o nego larga a novela, larga tudo para participar. Você vê a importância. Isso é muito bom, muito bom. Mas um dia eu vou combinar com você, para a gente participar de um encontro de Grupo de Rua.

E aí, a gente vai procurar o dia, para você participar. Para você ver como é que está hoje. Que é mais mudado. São palavras de Deus, é a Igreja que vai até as casas das pessoas. Não são as pessoas que vão até a Igreja. E sempre a gente dá prioridade em fazer nas casas de pessoas que não participam. Quando tem pessoas diferentes: "Eu posso ir na sua casa?".

"Ah, não sei o quê... a minha casa...".

"Não precisa dar nada. Não precisa dar café...".

Então, a gente dá prioridade que não precisa dar nada. Porque tinha época aí que fazia um banquete. Então, tinha pessoas que viam aquele monte de coisas para comer e beber, e na hora que chegava na casa dele, ele não tinha condições de dar aquilo lá. Então, ele não queria por causa disso. Chegou uma hora que a gente falou: "Não, vamos cortar isso aí. Não dá nada, não". Água para beber... tem que ter água. E tem água, não é? Então, a pessoa aceitava mais, porque não precisava dar nada. Quer dizer, ele, mesmo sem dinheiro em casa, vai poder fazer o encontro.

Então você ia até as casas das pessoas, ia visitar onde elas moravam, visitava o local, fazia o encontro. Os encontros nas casas das pessoas. Que a prioridade das CEBs sempre foi fazer encontro nas casas que não tem gente participando, o que seria o primeiro encontro. Sempre priorizava isso. Mas quantas vezes você não encontrava. O cara recusava. E retornava na minha casa, retornava na casa do outro, e tal e tal. É assim. Ficou isso até hoje. Então, quanta gente hoje que participa da Igreja, e que já esteve, no passado, nos Grupos. E que se conheceu, se descobriu, descobriu que tem vez e voz. E ele se descobriu através das CEBs. Na participação das CEBs. Então, dá saudade. Tenho muita saudade do que eu vivi. Muita, vivi muita...

A gente dançava quadrilha também. A gente se divertia. Não só rezava, não. A gente se divertia também. Era legal. (risos)

$\mathrm{Eu}$, dentro de mim, não me arrependi nunca. Nunca, nunca, nunca. Eu, tudo o que eu fiz... E olha que você é criticado. Muita gente critica. Por outro lado, tem aquelas pessoas que agradecem a gente, até hoje, às vezes. Porque através de você, daquela ligação, ele está firme na Igreja. Então, graças a Deus... E eu não quero ficar ouvindo isso aí, de me elogiar. Anima a gente. Você escuta uma palavra de ânimo. "Poxa, será que eu fui importante? Pelo menos com essa pessoa funcionou." Pelo menos essa pessoa... Não sei o que aconteceu com os outros por aí, mas essa pessoa está na Igreja com uma força que eu dei. Agora, quantas outras pessoas que você não sabe. Quantas outras pessoas que se mudaram daqui e foram para outro lugar, mas têm tudo o que aconteceu aqui e que viveram aqui com a gente. Que aprendeu aqui e que pode levar a outro lugar.

Tem uma mulher, que ela era animadora do grupo que era meu... meu assim, eu falo 'meu'... o meu grupo é de todos. É 'meu' assim, que eu participava, que eu era animador. (risos) E eu jogava na mão dela. No fim, ela se tornou uma grande animadora. E ela jogou no grupo da outra. A que está animando hoje, acho que é a terceira animadora. Eu falo para ela quantas vezes que eu falei -: "Não fiquem só vocês animando. Quando vão pessoas novas, dêem uma leitura para fazer, incentivem essa pessoa". Muitas vezes eles não dão. Ficam parados, ficam animando. Porque tem gente que tem ciúmes. Tem ciúmes de deixar o outro fazer e perder a vez de animador. Isso aí não pode. O animador tem que torcer para que aumente. Porque o dia em que ele não está lá, o grupo vai faltar por causa dele. 
É que nem: eu sou animador, marquei para a quarta-feira, mas fui fazer uma cirurgia no dente e não deu para mim. "Então, não vai ter encontro porque o João está com o dente machucado". Negativo. O encontro tem que ter, sim. Com o João lá ou sem o João, tem que ter o encontro. Tem que ter o animador. Porque sem o animador, ele vai começar a formar onde? Através de você. Você dando uma oportunidade para ele. Você dando uma leitura para ele ler no começo. E pode logo, nos encontros seguintes, já animar.

"Eu era igual a você. Porque que você não pode?"

"Ah, mas..."

"Não, você vai animar, sim"

Aí a pessoa animava, e animava muito bem.

E a pessoa animava com bastante carinho. Hoje, a animadora que eu deixei na época... há mais de dez anos deixei o grupo na mão dela, e ela está animando até hoje. Eu falei: "Olha, é muito bom ser você e tudo. Mas tem que deixar outras pessoas animarem". Para que não fique só uma pessoa, só ele sendo o animador, ele sendo a cabeça daquele grupo. Porque a cabeça são todos.

Quantas vezes eu ouvi falar: "Olha, eu parei de ir no grupo por causa de fulano". Ou: "Eu parei de ir no grupo por causa daquela mulher". Não foi só de uma.

Outra falou: "Olha João, eu não estou indo mais... Aquela mulher lá, foi muito chato o que ela falou na frente de todo mundo. Não devia ter falado".

"Não. Pelo amor de Deus, larga isso de lado... Olha, é assim mesmo, o povo de Deus, na época de Jesus, era assim. Não era todo mundo cem por cento, não. Tinha as reclamações, tinha as discórdias, tinha tudo. Era o povo de Jesus naquela época. O povo, hoje, não é tudo cem por cento. É por isso que as coisas rodam, viram. Tem que dar continuidade, mas na união. Tem que ser unido".

E é incrível, rapaz. (risos) Mas graças a Deus que essas mulheres são firmes também, que elas estão lá perseverantes no grupo. Estão lá animando. Deixou de formar aquele monte de animadores, mas estão animando. São perseverantes.

Isso aí é importante. Mas graças a Deus. Eu me sinto muito feliz. Não tenho arrependimento nenhum. $\mathrm{O}$ arrependimento que eu posso ter é de não ter participado mais ainda... de não ter ido num congresso... Tenho arrependimento de não ter ido em congresso nacional. Era para eu ter ido em congresso nacional - o Intereclesial. Não tive oportunidade. Sempre deixando o outro, e acabei não indo...

Eu fui num congresso estadual. Sempre você vai deixando o outro, a outra pessoa ir... "Ah, eu queria ir e tal...". Foi indo, foi indo e você acaba ficando... mas... é questão também do meu casamento, que eu procurava não ficar fora de casa muito para ter equilíbrio aqui dentro, no meu casamento. Minha mulher não aceitava que eu saísse assim, ficasse aí três, quatro dias num congresso. Porque quando eu fui num congresso lá em Piracicaba, em 83, eu era solteiro. Casado eu não fui para não ter conflito. Não adiantava eu cobrir um santo e descobrir o outro. Então, eu ia num lugar para ser bom, mas, por outro lado, eu criava uma discórdia, uma briga com a minha família, que era onde eu vivia todo dia, sob o mesmo teto. E eu não podia viver isso. Então, eu, para agradar ela também, deixava os outros irem. Acabei não indo. Agora, quem sabe um dia a gente vai conhecer isso. (risos)

Esses dias atrás - falando mais um pouquinho de mim -, cortando o cabelo do padre Mahon: "E aí, e a sua namorada? Eu não vi mais a sua namorada".

Eu falei: "Ó, padre Mahon, eu nem tive coragem de ir dentro da igreja. Às vezes o padre Félix está rezando lá. E ele falou que se eu estiver com a namorada, vai me expulsar de lá de dentro". 
Ele é o pároco, o padre Félix. O padre Mahon é o vigário. Ele falou que se me ver com a namorada lá, e se alguém cobrar, ele tem que me expulsar como ministro... todo o meu trabalho.

Aí, ele falou: “Quem é o seu conselheiro? É o padre Félix?".

Eu falei: "O meu conselheiro é o Mahon. É o Mahon, que é mais sábio".

Ele falou: "Então... Porque que você não está indo com ela na Igreja?!?!". (risos)

Porque ele me aconselhou, ele me ensinou como eu devia fazer. E ele falou para mim, quando ele me aconselhou para arrumar namorada: "Está com dificuldade de arrumar namorada? Eu tenho cinco para te apresentar. Se você não gosta de uma, pode gostar da outra. Eu tenho cinco!".

Falei: "Mahon, mas... né. Muito quebradona eu não gosto, não".

Mas eu pensei bem: esse Mahon quer arrumar alguma curva de rio para vir aí, né...

Eu falei: "Não é muito quebradona não, né Mahon?".

"Não. Trinta, trinta e poucos anos. Eu te apresento".

Eu falei: “Tá bom, Mahon. Depois eu peço para o senhor me apresentar". Eu não tinha arrumado essa aí ainda.

Eu fiquei com medo de ele arrumar qualquer uma e jogar na minha mão. (risos) Aí, eu falei: "Caramba, meu...". (risos)

Ah, ele é um barato. Aí, ele me falou: “O padre Félix é o seu conselheiro?”.

Eu falei: "Não".

"Mas quem é, então?"

"O meu conselheiro é o senhor, que é sábio".

"Então... O que você está esperando?" (risos)

É demais. Nossa!, aquele lá... Eu torço para ele viver tantos anos... Eu torço porque o dia em que o padre Mahon se for... Porque ele ficou mais de 20 anos aqui. Ele já se aposentou, tudo, e os caras já liberaram: "Agora você vai escolher o lugar onde você vai ficar, onde você vai morrer. Os últimos dias da sua vida, você vai escolher onde você quiser ficar. Em qual país você quer ficar?"

E ele veio aqui na comunidade São Geraldo. O amor que ele tem aqui... Porque ele ficou 10 anos na Santa Terezinha, ficou 10 anos em Mauá. Aqui, Ave Maria!, aqui são quase 30 anos...

O importante é que eu queria que você sentisse vindo no grupo. Vir participar do encontro, para você viver um pouco. É lógico, você não vai viver o que aconteceu no passado. Sentir um pouquinho. Uma porcentagenzinha do que eram as CEBs. Do que ficou. São frutos.

O que mudou é que naquela época tinha mais ação. Muito mais. Hoje tem menos ação. Mas é falado quase da mesma forma.

As CEBs, como eu falei para você, nossa!, revolucionou muito aquela época. Unia muito as pessoas. Quantas pessoas que participam ainda hoje na Igreja porque começaram no grupo de CEBs. É aquela pessoa que ninguém dava valor e ele, participando do grupo de $\mathrm{CEBs}$, sentiu que tinha algo dentro dele para doar. Ele tinha valor. Era uma pessoa valiosa. E ele descobria esse valor aos poucos, se aproximou da igreja e começou a participar. Então, é como o padre Mahon falava: nas CEBs, a gente nunca é um grupinho fechado, é um grupo aberto, é uma pessoa aberta. É a gente de mãos dadas, mas de costas um para o outro, olhando para o povo.

A gente vai na igreja e vai na casa da pessoa. E acolher. Acolher com amor, com carinho. Porque o padre Mahon é muito bom. O padre Mahon, quando tem um pastor, ele quer ser amigo, convida... Ele, uns tempos atrás, convidou uns pastores de um monte de Igrejas. Os caras vinham dos Estados Unidos tudo passear. Acho que tinha 16 ou 18 pastores 
na São Geraldo. Mulher pastora, homens, assistindo a missa. E na hora da comunhão, os pastores foram tomar comunhão. $\mathrm{O}$ respeito que tem.

Tem gente que conheci naquela época que vejo até hoje. Quer ver? Para você ter uma ideia, o cara com quem eu trabalhei, o motorista, vai na missa da São Geraldo até hoje. E eu falava para ele e ele não lembrava. Um dia, ele falou: "João, eu me lembro de você agora". O nome dele é Vitório. Eu falei: "Vitório, você lembra, rapaz, que você mandava eu mandar o cara pular a catraca, por causa da metade da passagem, para você comprar o cigarro e dar um pouco de guaraná para mim?". Mas, pô, eram cinco contos. Sobravam cinco contos. Ele comprava o cigarro de dois, dois e cinquenta, e sobravam dois, dois e cinquenta para mim. E nós mandávamos pular... que a catraca era baixinha assim. Qualquer manquinho pulava. Aí, pulavam uns lá, e ele pegava o dinheiro do cigarro dele e eu pegava o dinheiro que sobrava. Ele falava: "Tem que fazer assim para eu comprar meu cigarro".

Até hoje a gente ainda se vê. É a pessoa que mais marcou! Mais marcou. Foi esse cara, o motorista, em 70. Tinha uns que até pouco tempo eu via ainda. Depois sumiram.

Esse cara que era o meu motorista, é genro da dona Odemira. E eu conheci o marido da dona Odemira. Ele morreu há muitos e muitos anos. Eu conheci ele, que tinha o bar. Tinha o bar lá perto da igreja. Agora, o pessoal de 76, 77, essa turma aí... 78, 79, é um monte de conhecidos. Um monte.

O pessoal do Grupo de Jovens, tem uns que vêm de longe cortar cabelo. Daquela época: 78, 79, que e eu conheci lá na igreja. E uns aqui de cima, um monte de pessoas daqui de cima, espalhados, nesses anos todos aí. Hoje está fazendo quanto? Trinta e poucos anos. Trinta e um anos que eu conheci esse povo. O povo está tudo aqui. Tudo casado, uns largados, outros viúvos, outro estão casados de boa, estão com filhos, já é avô...

Naquela época de 76, quando eu vim aqui, eram cinco, seis meses de garoa! Garoa! Era a terra da garoa, nego falava. Era garoa direto, direto! Eu falava: "Pai, aqui está fazendo um frio. Mas frio, pai!", na carta, né. Que eu escrevia carta para o pai. "Aqui faz frio. Aqui garoa". Aí, o pai escrevia de lá: "Não, filho, mas aqui está fazendo sol”.

"Mas aqui faz frio. Faz um frio danado aqui". É fogo rapaz. Você lembra, né? Não sei se você pegou uma parte disso aqui ainda?

Lá no Paraná não era nada a ver. Porque lá no Paraná quando é calor, é calor. Lá no Paraná teve geada - sabe quando geia, né, vira gelo -, foi tão frio, tão frio, que quando foi sete e meia, oito horas da manhã, estava oito graus abaixo de zero.

$\mathrm{Na}$ época de 69, aqui em cima era muito morto. Não tinha luz na rua. Tinha poucas casas. Aqui tinha uma casa, aí tinha essa do lado, tinha outra. Aqui não tinha, aqui também não tinha, do outro lado não tinha. Onde nós moramos, aí no salão, eram uns eucaliptos. Aí era aquela rua. Aí eram uns barrancões, bastante terra. E eram uns eucaliptos, era uma estradinha. E até na São Geraldo ainda tinha asfalto. Mas tinha pouca casa também. Não tinha muita casa, não.

O asfalto vinha até na São Geraldo. E o ônibus vinha até aí também. E a igreja era bem menor, a São Geraldo. Porque a Igreja São Geraldo era pequena, depois construiu maior, e agora é grandona. Foram três construções. Então, a Igreja São Geraldo era pequena ainda. E eu me lembro bem que a turma era um povoado, não era muita gente. A turma subia tudo isso aqui a pé. Quem morava lá para cima tinha que andar pra caramba para chegar em casa.

Então, não tinha nada aqui no bairro. Nem guia tinha nas ruas. Não tinha esgoto, era fossa. Não tinha nada. Aí começaram as lutas com as CEBs. Em 80, nós brigamos por água. O esgoto tinha chegado. $\mathrm{O}$ esgoto chegou e em 80 nós começamos a brigar por água. $\mathrm{E}$ vai, vai, 
cobrar, cobrar... trouxeram a água. Veio a água. Aí, começamos a brigar por luz na rua. Brigamos, brigamos, fizemos abaixo-assinado, puseram luz na rua. Nas casas tinha. Não tinha essas luzes na rua. Era escuro. E eu trabalhava à noite, depois de 76. E lá perto de casa - do salão -, tem aquela baixadinha, aquela valetinha. Aí, passavam os caminhões e encalhavam ali e eu tinha que dormir de dia. O caminhão encalhava e eu não conseguia nem dormir direito. Eu ia com sono. Encalhava, era aquele barulhão, dia de chuva, e não tinha asfalto... E eu nem dormia direito... ia meio com sono trabalhar... Tinha que trabalhar de noite, de novo. Com sono... Na GM. Trabalhei até meados de 81 lá. Fiquei cinco anos e meio.

E nas CEBs tinha assuntos de fábrica. Falava sobre a pressão grande que tinha dentro das fábricas, o peão que não ganhava direito. E tocava no Evangelho. Lia o Evangelho e refletia na vida de hoje, vendo como é que estava.

Tinha mais gente que trabalhava nas firmas. E a turma toda tinha medo. Porque as greves começaram a nascer lá naquela época. Em 80, 81... Em 79, a gente nem participou. Não teve lá. Agora, na GM, em 80 teve, em 81 teve.

A gente nunca ouvia falar de greve. Eu cheguei lá na GM para trabalhar, estava tudo parado. O sindicato não foi lá, a gente não sabia de nada! Chegou lá, estava tudo parado. Queriam aumento, que não sei o quê, e tal. Eu cheguei para trabalhar e os caras: "Ô João, não pode entrar, não".

"E por quê?".

"Está de greve".

"Mas o que é greve?".

"Não, é que a gente tem que lutar por melhores salários. E você não vai entrar. Tem que ficar com a gente".

"Tudo bem, se não está entrando ninguém eu vou ficar com vocês".

Ninguém entrou. Rapaz!

Foi na época do governo Maluf*. Por isso é que eu não gosto do Maluf até hoje. Se vierem falar bem do Maluf hoje eu não aceito. Perto de mim não aceito que falem... Nossa, esse cara colocou muito cachorro. E aí, a polícia chegou com aqueles caminhões de choque. Não sei se você lembra... Você se lembra daqueles caminhões do choque que tinha antes? Chegaram acho que quatro caminhões. Tudo com soldado, e cada um com um cachorro. Rapaz! Soltaram no meio daquela peãozada! Mordia a peãozada e tacavam bomba lacrimogênio no meio. Eu já estava mais para a frente um pouquinho, a hora que eu vi que a polícia começou a bater, eu já saí correndo. Mas, rapaz, eu corri, corri, corri, e o cachorro atrás, o cara tacando bomba, aquela fumaça, o olho ardendo. Um policial tacou uma daquelas bombas lacrimogênicas, ela passou correndo por mim, assim, e estourou na frente. Eu passei no meio da fumaça. Arde muito o olho. E atravessei a Goiás que eu nem olhei pros lados. A Goiás era estreita, né. Se tivesse vindo carro me atropelava, por causa de tanto medo. De tanto medo... E cachorro correndo atrás. O cachorro parou, aí voltou, atravessou. E o policial voltou com o cachorro. Mas mordeu colega meu. Olha, foi uma covardia.

Ninguém estava fazendo nada, não tinha encrenca, era pacífico. A maioria estava lá de bobo, igual eu. Não sabia de nada. O sindicato lá de São Caetano sempre foi pelego, sempre foi sem-vergonha. Até hoje ainda é do lado do patrão. Fazia os acordos com o patrão. Enganava o peão. Aí, eu fui embora aquele dia. Disseram que não ia abrir. No outro dia, voltamos lá, aí deixaram entrar. (risos) Era tudo desorganizado. A gente não sabia nada. Não teve preparação. A gente estava que nem um Zé Mané, coitados, lá no meio dos outros, sem saber nada. Desorganizado. Se fosse hoje as coisas iriam ser bem diferentes.

E o Maluf falava que era vagabundo, que não queria trabalhar, e tal. Não é nada. Eram todos pessoas trabalhadoras que estavam lá. De uma forma ou de outra tentando melhorar a situação. Se tinha um sindicato que era pelegão lá, de São Caetano, que não valia nada, mas tinha um povo lá que queria alguma coisa. Queria uma melhoria lá dentro. E aí acabou, 
ficamos uns dias de greve. Nós acabamos perdendo a greve lá ainda. É fogo, a gente não sabia de nada... (risos) Eu não sabia nem o que era greve direito. (risos)

Eu contava para o pessoal nas CEBs. Eu contava o que aconteceu. Que o governador mandou a polícia lá e desceu o pau na turma. Todo mundo, os coitados, ninguém estava agitando. E foi falado que era tudo agitador. Por isso é que desceram o pau, foi falado. Não tinha ninguém, os coitados, os caras todos trabalhadores! Aquele pessoal enganado, igual eu fui lá. Que o sindicato chegava lá, fazia aquele barulho todo, e aliado com o patrão. Já preparando para mandar a turma embora logo.

Em 81 deu outra greve, depois fracassou, mandaram 1.680 embora. Foi em 81. Então, o sindicato é aliado com o patrão lá em São Caetano. Não era o sindicato igual ao de São Bernardo. Em São Bernardo, não. Era um sindicato forte, bom. Que reconhecia o direito das pessoas, lutava, ficava do lado do povo. Na época do Lula*. O Lula ficou até com o povão. Aquela época foi difícil...

Eu não estava no PT ainda. A greve foi antes. Depois dessas greves é que surgiu o PT. Aí, fui convidado. A minha entrada foi a participação na Igreja mesmo. Era grupo, eram pessoas de dentro da Igreja mesmo. Estava na igreja e me convidaram. Os trabalhadores de São Bernardo. "Nós estamos fazendo um partido". Era cara daqui que trabalhava em São Bernardo, na Volks.

"Formou o partido do PT, nós queremos que você se filie".

Aí, eu me filiei em 80, em 81... Foi logo no comecinho que eu me filiei ao partido. Quem me convidou foi o tal de Dino... O Dino, neguinho. Conhece? Hoje já se desfiliou. Mora no Clube de Campo. O Dino: "Vamos, vamos, vamos". Ele fez parte das CEBs também. Virou, mexeu, ele vinha no grupo. Virou, mexeu, participava. E o Dino era atuante. O Dino era forte. Tem bastante garra o Dino. Era um cara bom. Aí, a Tina, na época, entrou também. A Tina, não sei se você se lembra, e o Zenir, o marido da Tina? Entrou uma turma. Lá, na época, tinha a ACO da igreja, a Pastoral Operária. Aí, a gente se filiou e tudo. Vinha bastante gente. A gente se filiou aqui mesmo. Aqui na esquininha da igreja. Alugaram um salãozinho. Puseram comitê e a gente se filiou aí. E estou até hoje filiado.

Teve coisas que eu desgostei no meio do caminho, que eu queria me desfiliar. Liguei, mandando os caras encerrarem o meu nome, de tanta palhaçada que tinha. Os caras do PT envolvidos em corrupção. Então, você fica meio nervoso. Porque, pô, é o partido do povão. Aí, falaram que eu tinha que escrever carta, tal, tal, tal, não sei o quê... Acabei não me desfiliando. Eu fiquei... eu falei "não!". Depois eu fiquei pensando bem: "se eu sair eu estou abandonando o barco". Se a gente tem que lutar, tem que lutar para endireitar, para melhorar, e não abandonar. Se tem um torto, tem dois, três que são bons. Quando tem um que não presta, tem dois ou três que prestam. A ideologia do PT era a melhor que tinha. Era, porque era um partido formado por trabalhadores. Era o melhor partido que tinha no momento. Que até hoje, na minha opinião, mesmo com o que aconteceu com esses corruptos aí que teve do PT, ainda é o partido de melhor proposta para o povão que sofre. Até hoje é o PT. Não tem outro. Tem uns aí que são mentiras, né. Eles andam prometendo mundos e fundos, mas não estão no poder. É até ele ganhar o poder. Depois que ele ganha o poder, não faz nada. E o PT não. Já deu testemunho que faz. O Celso Daniel* fez muito. Lá em Diadema o cara fez muito. O Lula trabalhou muito. Você vê que está sempre do lado do povão, para tentar melhorar a situação do povo.

$\mathrm{Na}$ época, foi aquela filiação que se deu. E a turma se reunia e conversava. Teve organização para nós escolhermos quem seria o candidato do bairro. E aí, quem era candidato do bairro? Teve, acho que, umas três pessoas. Eu lembro muito do Tarcísio, do Dino, do Fúlvio. Eu sei que a turma votando, escolhia um. Escolhia um para representar o bairro. E esse um, quem foi o escolhido, eu lembro muito bem, ele quase que ganhou por um 
pouquinho de voto. Por pouquinho voto ele não ganhou. Um cara também muito bom, o Tarcísio, ele quase ganhou. Foi o primeiro candidato aqui e quase ganhou, do PT. Depois foi o Dino, ficou. QUASE ganhou também. Era das CEBs. Então era tudo o pessoal... a maioria das CEBs tinha simpatia pelo PT.

Eu sei que se candidataram o Tarcísio, o Dino, o Fúlvio e depois foi a Tina. A Tina ganhou, acabou ganhando. Ganhou dois mandatos seguidos. Mas só que a Tina, quando ela ganhou, não satisfez muito a nós do bairro não, sabe. Deixou muita coisa a desejar. Porque, geralmente, quando o vereador do bairro ganha, ele tem que lutar pela cidade toda. Mas só que, geralmente, ele puxa uma sardinha para o bairro dele, né. Ele faz uma coisinha a mais para o bairro dele. E o nosso bairro, muitas vezes, ficou às moscas. Não fez muita coisa para o nosso bairro, não. Fez pouca coisa. Fez por Santo André, ajudava a aprovar muita coisa lá, foi boa vereadora lá, mas para nós aqui deixou a desejar.

Ah, e teve o Perseu! Era do PT. E ganhou. O Perseu ganhou estourado. E nossa! O tanto que eu ajudei o Perseu! Nossa Senhora! O Perseu, não sei se ele morava para o lado do Humaitá... ele vinha para cá... E ele freqüentava aqui. A base dele, para ele ganhar, foi mais aqui. Eu ia de carro, levava... Nós fazíamos festinhas para arrecadar dinheiro, tudo do povão, ajudava, ajudava. No dia da eleição, pegava o carro, lotava para levar os fazedores de boca de urna lá. Levar no outro, levar no outro, levar no outro, para fazer o Perseu ganhar. Até que ele ganhou. Depois que ele ganhou, não deu muito respaldo para nós também, não. Deixou meio de lado. Ele foi deixando aí meio abandonadão. Até que depois a turma não quis mais ele.

O Perseu foi o quente das CEBs na época. Ele chegou a trabalhar nas CEBs. O Perseu chegou a trabalhar para a Diocese mesmo. Tipo funcionário. E se eu não me engano, era até pago. O Perseu era até pago para trabalhar, que era o trabalho dele, de organização. Foi antes da Tina ainda. E ele tinha uma grande organização, poder de organização. Ele era um cara muito dinâmico. E ele ganhou. Ele saiu das CEBs daqui.

Quando ele entrou como vereador, ele já se afastou das CEBs. Até as CEBs era candidato. Ganhou, se afastou. Então, ele se queimou. O Perseu se queimou. Ficou um mandato. Não ganhou mais, não. Depois se candidatou de novo e perdeu. Foi assim que começou o PT. Não sei se foi no primeiro mandato ou segundo mandato... Foi no segundo mandato do PT que ele ganhou. Ele era um cara muito dinâmico. Todo mundo conhecia ele. Ele andava com o carro da Diocese, pra cima e pra baixo, organizando as CEBs, e tudo. Quando ele se candidatou, foi deixando um pouco as CEBs de lado. Foi deixando, deixando...

O Dino não foi eleito, mas chegou perto. O Tarcísio chegou perto também. Agora, o Tarcísio, não sei se você conheceu ele naquele dia no Curso Bíblico? Aquele que estava questionando. Parece que ele é meio revoltado contra Deus. Está meio revoltado... Não sei se é porque a mulher dele morreu... Para você ter uma ideia, o filho dele se candidatou a deputado federal e eles apoiavam outro aqui em Santo André. Não faziam campanha para o filho. Por que o filho era de outro partido. Era presidente de outro partido lá e foi candidato. E ele não apoiava o filho. Ele apoiava o cara que era do PT.

Eu sei que a Tina ficou duas gestões e pouco fez para nós. Porque, sabe o que ela queria e por isso se queimou? Ela queria colocar o lixão aqui no tancão, cobrir o tanque, pôr lixo e uma fábrica de piche. Ela e o Celso Daniel queriam isso para cá. Ah, a turma se revoltou. Tacaram ovo na cara dela lá na Câmara. Falaram palavrão para ela pra caramba lá. Chamaram de vagabunda, de sem-vergonha. É meu... ficou ruim para ela... ficou ruim. Queria esvaziar o tancão e encher de lixo. E fazer uma fábrica de piche. Imagina uma fábrica de piche aí. Quanto que fede aí o piche. E a turma não aceitava.

A mulher que sempre defendeu, que sempre estava na comunidade, ajudando na comunidade, defendendo o tancão, o meio ambiente, defendendo para fazer um parque, deixar bonito aí; de repente a mulher lutando para conseguir passar o terreno numa concessão de 60 anos! Você acha? Onde se viu? Muita coisa, né. Para essa fábrica de piche... Queriam dar uma 
concessão de 30 anos podendo renovar por mais 30. Você acha? A turma acabou... A turma do bairro foi de ônibus lá. Nossa! Xingaram ela demais, acabaram com ela. Não ganha mais, está queimada. Ela se queimou. Ela nem se candidatou mais.

Agora está o Fabrício aí, que se candidatou e perdeu. Não sei se vai se candidatar de novo... Eu vou falar a verdade para você: para achar um vereador dinâmico aqui no nosso bairro, não apareceu nenhum. Apareceu a Tina, que ganhou mas não fez nada para nós. O que a Tina fez? Nada. É cruel... Política é fogo...

Eu me lembro da Messias*, do marido dela - o Roberto*. A gente tinha muita amizade. Ela também participou do PT. A Natalina*. Um monte de gente aí. Natalina, Messias... A Dirce*, a Madalena*. Participaram tudo.

A gente fazia boca de urna DE GRAÇA, na época. Não pagavam, não. Ninguém pagava. A gente fazia. O PT ganhava. A gente era atuante. Não tinha que pagar nada, não. Nossa! Na época do Celso Daniel, nós fizemos campanha para ele ganhar. Foi difícil mas... Deu uma melhorada em Santo André do caramba, viu. O cara era muito inteligente, hein. Se não tivessem matado ele, provavelmente era o nosso Presidente da República. Ele era o braço direito do Lula. Ah, COM CERTEZA era o presidente. Com certeza. Ele era um cara muito inteligente. E uma pessoa muito inteligente que estava do lado dele era a ex-mulher dele. É separada. Uma mulher muito inteligente, que ajudava muito ele em Santo André. Acho que é Miriam*... Miriam Belchior. Ela hoje está convidada pela Dilma* lá. Não sei se é Ministra lá. É um dos braços direitos da Dilma. A mulher é super inteligente. Ela ajudou muito o Lula lá na Assembléia. A mulher é MUITO inteligente. O Celso Daniel fazia as coisas, mas a inteligência era da mulher dele. A mulher dele é que era inteligente. Sempre atuava junto.

Sei que foi um momento bom, viu. Passamos um momento muito bom. De trabalho na Igreja. Tinha MUITO trabalho. Hoje, a gente vai na missa e tudo, leva a comunhão para os doentes, às vezes reza o terço, tem os Grupos de Rua... Até hoje tem os Grupos. Antigamente eram as CEBs. Hoje eles falam 'Grupo de Rua'. Mas antigamente eram as 'Comunidades Eclesiais de Base'. Eram pessoas comprometidas para resolver. Ia, cobrava e resolvia. Cobrava das autoridades. Cobrava ônibus, cobrava um ônibus melhor, mais confortável, mais ônibus na linha, passagem mais barata.

O Celso era o presidente dessa organização que nós tínhamos, dos ônibus. A gente calculava quanto tinha de gasto e o quanto tinha de lucro - baseava mais ou menos no lucro -, e baseava na passagem. Tinha que baixar a passagem. O padre Mahon conseguiu. Ele lá representando, e nós na base. Umas duas vezes baixou a passagem. Umas duas vezes conseguimos ter vitória.

O Lula veio em comício aqui na São Geraldo. Na época em que ele perdeu a eleição, em noventa e poucos. Veio, falou bastante. A gente ia em carreata. Eu participava. Era atuante mesmo, sabe. Usava bonezinho vermelho - um bonezinho com uma estrelinha -, discuti com os caras no salão... Perdi cliente pra caramba, discutindo. Tentando uma melhora, uma mudança no país. Porque... a ditadura foi até que ano? Quando a gente começou a sair era na ditadura ainda. Em 80 acho que era ainda, não era? Em 79? Era ditadura naquela época. Precisava tomar cuidado com as polícias naquela época. Para sumir com um cara era fácil. Então, era época da ditadura. E a gente era totalmente contrário mesmo.

A participação era mais aqui com o pessoal. Tinha um japonês que trazia umas coisas eu não lembro o nome dele -, trazia para nós, fazia reuniões de vez em quando, sobre a participação e tal.

Eu lembro que na época, em 85, eu estava no Grupo de Jovens que foi passear no Paraná. Fui com o bonezinho vermelho e tudo. Falei do Lula para a turma lá.

"Que Lula! Você está é louco! Aquele cara é comunista!”. 
"Não, aquele cara é comunista o caramba! É o cara que vai mudar o país".

"Não, não. É comunista, não sei o quê...".

"Vocês vão ver um dia: o Lula vai ser presidente. Vocês vão ver. Um dia eu vou voltar aqui e eu vou lembrar de vocês. Vai ser presidente".

"Quê! Esse cara é comunista". E tal e tal.

E o Lula foi presidente por 8 anos. Deu um show na presidência, né. Porque pegar o país do jeito que ele pegou, e o poder de negociação que ele tem. O Lula, o poder que tem de negociação na mão dele. E eu lembro quando... não sei se foi o Morales* lá... que tomou a Petrobrás lá do país dele, acho que é a Bolívia. Foi Bolívia. Que tomou, meteu os policiamentos, o exército lá, invadiu a Petrobrás. O Lula cheio da manha, chegou lá e negociou com os caras... Negociou, negociou e negociou, e não faltou o gás. Porque o Brasil dependia. 60, 70 por cento do gás que consumia no Brasil, dependia deles lá. E o Lula negociou, negociou e ficou tudo em paz. Ficaram lá e estão resolvendo o problema. Ainda não está bem resolvido da Petrobrás com os caras lá. E ele conseguiu que não faltasse nada no Brasil. Deu a volta por cima. Eu lembro, na época, que o Alckmin* falou que ele era muito frouxo. "Porque tinha que mandar o exército, tinha que fazer retaliações contra a Bolívia, tinha que...". Porque se o Lula vai na do Alckmin, os caras cortavam o gás do Brasil. E o Brasil ia fazer o quê faltando 60, 70 por cento do gás aqui no Brasil? E ele, um peão do trecho aí, conseguiu essa negociação, esse poder de negociação. Isso eu acho que é coisa de Deus: um ser humano ser tão inteligente desse jeito. E conseguiu. Ele fez de tudo. Não importou perder, a Petrobrás fica lá. Mas no dia em que o Brasil tiver gás suficiente, aí a coisa é diferente. Aí, você pode bater o pé no chão. Mas enquanto você depender dos outros, você tem que saber negociar e saber conversar. Porque, na época, se a gente tivesse o Alckmin de presidente, o Brasil podia ter um colapso aqui, ter travado o país. O Lula tem esse carisma, essa amizade. O cara pisa na garganta dele, ele vai lá...

No começo, o Lula andou vindo aqui. No começo, ele visitava muitos lugares. A gente teve aproximação dele. Até que eu peguei uma vez um autógrafo dele num chapéu meu. Eu guardei o chapéu. Nem sei onde é que está. Eu guardei... Foi a primeira vez que ele foi candidato. Acho que não era nem nos anos 90 ainda. Foi nos anos 80 e tralalá. Na primeira vez que ele foi candidato. Ele veio aqui, peguei uma assinatura dele. O único que eu tenho até hoje, do Lula. Eu falei: "Esse cara vai ser presidente". Eu guardei o chapéu e ele foi presidente.

É um cara que não tem sujeira com ele. É um cara que deu a resposta para todo mundo. Que quiseram incriminar ele, quiseram detonar ele, mas ele deu a volta por cima pelo carisma dele, pela inteligência dele, o poder de negociação. Os países todos entraram em situação difícil, e o Brasil foi o último que entrou e o primeiro que saiu da crise. Então, foi uma coisa de Deus que aconteceu no Brasil.

Porque era a proposta das CEBs, mais ou menos assim: era a gente fazer para que todos tenham direito. Não só o milionário ter poder e o pobre passando fome. Então, a proposta das CEBs é essa: que todos tenham vez e voz. Que todos tinham o direito de falar, todos tinham o direito de se respeitar um ao outro, de ele ser um cidadão comum, de ele ter participação. As CEBs ensinavam tudo isso, essa visão.

Tinha outras pessoas que eram das CEBs e do PT. Os grupos estavam espalhados. A turma odiava no começo. Falava que era comunista, né. Eu achava que a turma estava com a mente travada ainda. Ainda estava ligada à escravidão lá, ao regime militar. Então, a gente colocava o Evangelho, tudo, falando de Deus... E em cima do texto do Evangelho, você colocava que o país estava numa situação errada, que você não tinha direito, que não tinha nem liberdade para expressar uma verdade, que você podia ser até morto. E a gente procurava libertar essas pessoas. Porque as CEBs é libertação. É liberdade. É você ter vez, voz. É você saber que é um ser humano como qualquer um e que tem os mesmos direitos. E muitos 
direitos das pessoas eram cortados, eram retaliados. Enquanto uns tinham demais, outros de menos. Porque o nosso objetivo nas CEBs era sempre uma sociedade igualitária. Uma sociedade igualitária. Então, para chegar numa sociedade igualitária, pô, é muito difícil. Ter aquelas pessoas tendo todos os direitos é difícil, né. Quando você quer adquirir um direito, já tem um grande lá te tesourando. Falando que você é comunista, que é isso, que é aquilo. Então, é difícil. Não é fácil, não.

No nosso meio não teve tanta gente perseguida. Acho que o mais perseguido foi o padre Mahon mesmo. Ele foi a pessoa mais perseguida. Ele foi preso umas duas ou três vezes. Houve muita perseguição contra o padre Mahon. Só que, por outro lado, por ele ser padre, todas as vezes que pegavam ele, já tinha o telefonema de que ia chegar na delegacia e tinha o advogado da Diocese lá. O Dom Cláudio* foi muito bom. O bispo Dom Cláudio. Se fosse esse cara aí que está hoje... esse é um pelegão do caramba, esse que está aí. É um pelegão. Eu não sei se você ficou sabendo o que ele aprontou nas eleições ${ }^{4}$. Como é que ele pode ser de direita? Ele, o padre Otávio - o BISPO, o DOM Otávio. O DOM lá. O DOM, se ele quer nome, né. Ele, o Dom Otávio e o bispo de (local), que eu não sei o nome do cara e nem pretendo saber. E esse aqui, de (local). Esse aqui é um absurdo. Um absurdo... Se eu estou na missa e aquele bispo chega, eu fico chateado.

Como é que uma pessoa de Deus, um pastor, para colher as ovelhas, joga os lobos no meio das ovelhas? Quer jogar o lobo no meio das ovelhas, para catar as ovelhas. O que é isso? Ele tem que proteger e não trair as ovelhas... dar uma de Judas. Trair, não. Por causa de dinheiro? Por causa de construção de prédio da Diocese? Pára com isso.

O Dom Cláudio, sim. O Dom Cláudio abriu a igreja, e na época a polícia arrepiando os metalúrgicos, batendo. Ele mandou todo mundo entrar dentro da igreja. Ele estava junto. Dom Cláudio é nota dez. Nota dez para ele. A polícia entrou até dentro da igreja batendo na turma. E ele estava.

$\mathrm{Na}$ época, eu participava mas não tinha contato com o Dom Cláudio. Eu tive mais contato com o Dom Cláudio depois que eu estava trabalhando no salão. Inclusive, ele vinha cortar o cabelo aqui. O padre Mahon apresentou ele para mim.

Ele falou: "Quem corta o seu cabelo? Eu gostei do seu corte de cabelo".

Ele falou: "É o João, tal, tal...".

E ele começou a cortar o cabelo aí, o Dom Cláudio. Cortei cabelo muito tempo. Aí, um dia, eu estava falando para o padre Félix: "É, padre Félix... você vê... acho que a pessoa mais importante na minha vida que eu cortei o cabelo até hoje foi o Dom Cláudio".

Você vê? É a terceira pessoa da Igreja Católica do mundo! E ele falou: "E você não tem uma foto do lado dele, né?". Eu falei: "Eu não tenho...”. Ele falou: "Então, você perdeu. Devia ter uma foto do lado dele". "Não", eu falei, "não tenho nenhuma foto!". (risos)

Agora ele saiu, ele pediu demissão. Entrou outro no lugar dele. Nossa, era uma pessoa maravilhosa! Alegre, contente. Quando eu casei, em 89, eu dei o convite para ele. Ele não pôde vir porque bispo tem muito compromisso, né. E ele mandou um telegrama para ser lido na hora. Ele pediu para o padre Mahon ler na hora da minha Celebração. O padre Mahon leu o telegrama que o Dom Cláudio mandou desejando felicidade para mim, que Deus iluminasse a minha vida, o meu casamento. E ele pediu desculpas por não estar presente, que ele já tinha outro compromisso confirmado para aquela data. E aí, o padre Mahon me deu para eu guardar de lembrança. Eu guardei, mas você sabe que muita papelada... acabou sumindo. Não vi mais

\footnotetext{
${ }^{4}$ Aqui, João se refere à carta que recomendava aos cidadãos, durante o período das eleições de 2010, para que somente votassem em candidatos e candidatas contrários à descriminalização do aborto. Esta carta elencava uma série de fatos que denotavam uma tendência do PT e, consequentemente, de sua candidata à Presidência da República, à descriminalização. Foi assinada por três bispos e causou grande polêmica na época, entre outras razões, pela discussão em torno da influência direta de setores da Igreja Católica nos rumos das eleições e pela dissonância entre estes setores e outros que contestaram a representatividade do grupo que elaborou a carta.
} 
o telegrama. Ele era muito amigo meu, o Dom Cláudio Hummes. Muito amigo. Infelizmente, ele foi embora. Mas fez muita falta para nós no ABC. Muita falta.

Aquele outro que entrou substituindo, era muito bom. O Dom Décio*. Uma pessoa maravilhosa. Subia nas favelas comigo. Ele era humilde. Ele chegava na igreja e abraçava todo mundo. Ia na equipe de festa, abraçava todo mundo, comia lá... Vai ver se esse faz isso. Nada... O que é isso? É poder, né. O cara quer nome. Eu acho que a pessoa mesmo - e isso a gente aprendeu nas CEBs, aprende na Igreja -, a pessoa tem que aprender a ser humilde. Nome tem aquele que é humilde.

O padre Alfredinho*... Aquele lá... o padre Alfredinho é tudo de bom, viu. Você quer ver, quando chamava ele para almoçar, punha a mesa para ele e ele dispensava. Ele cata uma comidinha só assim, põe no chão e come na parede. Você fica com vergonha. Você não sabe como comer perto do padre Alfredinho. (risos) Põe a mesa, ele pega aquele pratinho, sem mistura, senta no chão e come. Sem mistura. Nossa! Você fala: "Meu Deus, por que que eu fiz essa mesa?". Ele dá para a gente perceber assim: "Por que você não faz isso com todo mundo: arruma a mesa para os pobres aqui e chama?".

Ele é fogo, o padre Alfredinho. Dava exemplo. Ele morava numa casinha, num barraco na favela. E não tinha fogão a gás, não tinha nada. Aí, ele ia cozinhar, ele catava as madeiras por aí, só no fogo. Cozinhava lá, comia. A cama dele era um estrado no chão, assim, com uns panos. Dormia. Não tinha nem colchão... não tinha nem colchão a cama do padre Alfredinho. E você chegava na casa dele, ele já recebia você, já esquentava um chazinho gostoso que eles faziam lá e dava. Ele tinha uns lugares, uma hortinha, em que ele plantava bastante coisa, remédio: hortelã, poejo, babosa, um monte de coisas... O remédio, usava tudo natural para a turma da favela.

Ele apaziguou muito aquela favela, a Lamartine. Matavam nego direto. O padre Alfredinho começou, com a turma: faziam 'Passeata da Paz' nas vielas, nas ruas. Passeava rezando e cantando. É Deus que põe a mão assim, ó. Os crimes... acabou aquela matança... O cara que bebia pinga... Quantos caras que bebiam pinga começaram a ir na igreja, deixavam a pinga... Nossa! Ele foi tudo de bom. Eu tenho umas fotos com ele. O padre Alfredinho é muito bom.

Ele ia lá em casa... eu tenho uma irmã paralítica. Com 44 anos, ela faleceu. Ele ia lá, ela estava na cama, a mãe pedia para ele abençoar... Ele falou: "Ela é que tem que me abençoar". Ele se ajoelhou na frente dela e falou: "Meu Deus, nossa, como eu estou distante desse ser humano que sofre tanto... dessa santa aqui...".

E pedia para ela: "Ó, me dá proteção...”, para a minha irmã que nunca andou e nem falou, "me ajuda, intercede a Deus por mim, para me abençoar em minha caminhada". Pedia para a minha irmã! E se ajoelhava na cama dela, o padre!

O padre Mahon foi lá três vezes, velhinho, visitar a minha mãe. O padre Nelson foi cinco vezes. $\mathrm{O}$ padre Mahon, aquele amor... O padre Alfredinho... O padre Alfredinho não saía da casa da minha mãe. Falou: "Eu vim na casa. Eu vim visitar as minhas santas". Eram a minha irmã e minha mãe, que cuidava dela.

Dos padres que passaram pela São Geraldo, primeiro era o padre Roberto*. E eu só assistia as missas, nos anos 77, 78, 79... Era um francês. Amigo do padre Mahon. Depois, aquele padre Roberto saiu, foi embora. Aí, vieram três: veio o padre Ivo*, o padre Carlos*, e o padre... Teve um até que se envolveu com uma menina do Grupo de Jovens lá da Vila Linda e acabou casando. Era um deles. Mas o Ivo e o Carlos não. Um era o Bernardo*, um era o Carlos, e o outro era o padre Ivo. Eram os três. E teve um deles que casou. Agora eu não sei se foi o Bernardo... ou o padre Carlos... sei que um deles casou. Ela era do Grupo de Jovens lá da Vila Linda, do Cristo Operário. 
Eles eram assim... o Ivo tinha o olho bem claro. Ele era muito batalhador. Ele não ficava só na pregação, mas ajudava a reformar a igreja, a mexer, trabalhava. Esses três ficaram um bom tempo.

A igreja formou três seminaristas, mas não eram Filhos da Caridade, da turma do Mahon. Não sei se eram da Diocese, diocesanos. Formou o padre Otávio, o padre Cirineu e o padre Ricardo. Os três foram os primeiros padres a serem formados aqui na nossa comunidade. Mas não eram Filhos da Caridade. Acho que eu comentei, da outra vez, sobre o padre Otávio, que hoje é bispo. Sei que subiu pela cabeça dele. (risos) Aí ficaram o Cirineu e o Ricardo. O Ricardo, ultimamente, eu fiquei sabendo que está no Curuçá, naquela igreja do Curuçá. E o padre Cirineu, eu acho que ele está aqui na (local). Tomava uma cachaça danada também. Mandaram ele para Roma. Ficou 2 anos lá na reciclagem. Hoje ele está aí na (local). Acho que é muito bom padre. Preciso ir uma hora lá ver ele. Faz mais de 20 anos que eu não vejo ele.

Então, foram os três primeiros que se formaram aí. E eles eram comprometidos, os seminaristas. Nas greves, participavam, ajudavam a organizar, orientavam a gente. Quando tinha as invasões, eles nunca incentivaram as invasões. Mas depois que estava lá dentro, a Igreja tinha que apoiar. Não podia deixar sair que nem cachorro, apanhando. Então, a Igreja sempre estava junto. Depois que estava lá, apoiava para a polícia não arrancar no pau. E padre no meio já é uma autoridade, né. Os policiais já respeitam mais.

$\mathrm{Eu}$ senti discriminação de muitas pessoas. Teve pessoas que pararam de ir na igreja, falaram que o padre ficava falando em política. Mas não era. O padre falava em política. Diante daquele Evangelho que era rezado, Jesus praticou política na época. Jesus, na época lá, chegou na igreja dele e a turma estava fazendo comércio. Ele bateu nos caras, tirou na porrada de lá de dentro da igreja dele e falou: "Não. Aqui não". Ele lutava. Ele procurava negociar também com aqueles reis para ter a melhora do povo. E isso aí, a gente sentia essa necessidade, diante daquele Evangelho que o padre colocava. A necessidade que a gente tinha de se engajar nos movimentos. A gente falava: "A gente não pode ficar de braços cruzados. Nós temos que participar. Nós temos que cobrar os nossos direitos. Nós temos os nossos direitos. Jesus, na época dele, cobrava os direitos. E nós temos que cobrar os nossos direitos. Nós temos que participar dos encontros, temos que participar das entidades. Ainda tem que fazer se mexer. Por que de que vai adiantar só vir aqui e rezar?", o padre colocava. E tinha muita gente que já não aceitava. Discriminava. Achavam que o padre chegava lá e só tinha que rezar o Pai Nosso, a Ave Maria, e rezar a missa e não falar nada disso. Mas o padre, diante do Evangelho do dia, colocava a gente em cima. Então, muita gente parou de ir na São Geraldo. Muita, muita, muita. Que o padre se abria bem. Falava que nós tínhamos que participar.

Tive muita discussão por isso. Nossa! No salão, quanto! Principalmente no salão.

Nego falando: "Pô, João, você está lá dentro da igreja, meu. Você não vê isso não: o padre ficar falando de política?".

Falei: "Que dia você ouviu o padre falar?".

"Esse padre é tudo do PT".

“Que dia você viu o 'PT' lá dentro? Falar 'PT'? Me conta. Nós vamos conversar com o padre. E eu vou com você".

"É... ouvir falar do PT eu não escutei, mas dá para saber a política que é. Está tudo indireto".

Falei: "Olha, nunca escutei falar do PT lá dentro. Nunca, nunca. O padre mostra para nós o caminho que nós temos que seguir. E você escolhe. Você escolhe. Vou ficar de braços cruzados?". 
Então, diante do Evangelho você sentia necessidade, você tinha que participar. Não adiantava nada eu ficar rezando, rezando, rezando, e ficar de braços cruzados. Tinha que fazer alguma coisa. Era obrigado a fazer alguma coisa. Então, a gente participava. E a gente era discriminado. Os caras vinham criticar. Sabiam que eu participava da igreja, falavam: "Ah, essa sua igreja é uma porcaria... fui lá na missa e não volto mais".

Era muito preconceito. O cara vinha no salão e discutia. E foi o cara defender o Maluf. O cara defender o Maluf, para mim, ele está me sacaneando. Porque eu vi coisas concretas que aconteceram na minha vida. Vi quem é o Maluf. O cara vir elogiar ele para mim, eu não aceito, não. No salão eu já perdi muitos clientes. Os caras falavam sempre que o PT é subversivo e não sei o quê. Que a igreja era do PT, que não ia mais na minha igreja.

Eu falei: "Não, meu, se você não está a fím de mudar de religião, vai na igreja do Centro. Vai em um monte de lugar. É que o padre aqui, ele não tem medo de falar, não. Ele fala a verdade. Ele coloca nos dias de hoje o que a gente tem que ser. A gente tem que acordar".

Mas, infelizmente, o católico anda dormindo. A gente tem que acordar. Tem que ficar esperto porque chega de ser enganado a vida inteira. Que a gente foi enganado, os pais da gente principalmente. Foi enganado por aquela ARENA. Era MDB e ARENA, primeiro, que eu me lembro das políticas aí. Isso era tudo pilantra. E aí, a gente vai ficando esperto. O MDB era oposição. E a ARENA era do governo.

E o patrão ia lá na roça, que nós éramos empregados na roça, e falava: "Ó, você tem que votar na ARENA, hein. Vota na ARENA. Se você não votar na ARENA, os outros são comunistas. Não vota, não".

Aí, o meu pai votava só na ARENA... (risos). Iam buscar a gente no sítio. Nós trabalhávamos no sítio do cara. Ele ia lá. Ele é quem mandava no nosso voto. Do meu pai, dos meus irmãos.

"Vocês têm que votar na ARENA!".

A ARENA era, naquela época... a ARENA era ditadura... dos anos 68, 69, 70, 71, $72 \ldots$

"Porque os outros são perigosos, são tudo comunistas. Se vocês votarem nos outros, vai dar uma guerra aí, ó, vai morrer nós tudo".

E a gente tudo com medo de morrer, votava. (risos) O cara fazia a cabeça do meu pai, dos meus irmãos. E aí, na época da eleição, eles iam buscar de carro, iam buscar com a caminhonete, um caminhão, iam buscar aquele monte de sitiante, e levavam lá para votar. Votava. E depois dava lanche para todo mundo, bebida, guaraná. Tomava guaraná duas ou três vezes por ano. Quando tomava um guaranazinho assim, tinha que votar para eles. (risos)

Eles não viam em quem estavam votando. Até a maioria era analfabeta. Aí, mandaram o nosso vizinho que foi junto lá e falou: "Você já votou para o Sadao*?".

Era Sadao o nome do cara. Era o Sadao e o Waldyr*. O Sadao era da ARENA. O Waldyr Pugliese era do MDB.

"Eu votei".

O Sadao falou assim... ele pegou o papelzinho e falou assim: "Em qual que você fez o'X'? No do lado de cima ou no do lado de baixo?".

"Ah, eu fiz no do lado de cima".

"Ah, você fez no do lado de cima? Seu cachorro!”, e tomou o sanduíche dele. Ele era analfabeto. Ele falou "em cima". Jogou, né, pois não sabia qual que estava em cima e qual que estava em baixo. O de cima era o Waldyr Pugliese. Mas era a ARENA que tinha levado ele. Tomou o lanche dele, saiu correndo atrás dele, enfiou o pé na bunda dele, falou: "Some daqui da nossa festa, seu cachorro!". O cara teve que vir embora a pé, 8 quilômetros. (risos) Tomou o lanche que ele estava comendo, não deixou ele acabar de comer. (risos) 
Foi igual... tem um colega aqui atrás - está fazendo uns dez anos - e o cunhado dele, lá no Norte, foi no dentista que o candidato lá mandou, dizendo que ia pagar para arrancar o dente e pôr a chapa. Aí, o cara foi lá no dentista para arrancar o dente. Chegou lá, tudo preparado, e foi o candidato, na hora, que ia pagar o estrago lá. Deu o papel para ele: "Para quem você vai votar?". Era ele e o outro - a oposição. Ele apontou para a oposição. Não apontou para ele, para o cara que ia pagar. O cara ficou tão irritado, rapaz, que falou para o dentista: "Pode arrancar tudo". Aí, ele pegou e arrancou todos os dentes de cima, os dentes bons. Era para ter arrancado eu acho que só quatro, na frente, para pôr ponte. $\mathrm{O}$ cara arrancou todos os dentes dele. Arrancou, rapaz... Arrancou e costurou. Aí, fez aquelas bolsas de sangue. O cara foi embora, começou a dar febre, febre... Faz uns dez anos. Faz pouco tempo. Parece que ele falou escondido para o dentista que era para arrancar tudo. Aí, arrancou tudo. O cara costurou tudo a boca dele. Aí, foi dando aquelas bolsas de sangue. Foi dando febre no cara, internaram o cara, aí vai ter que ver de lá, o cara morreu... o cara morreu...

A turminha está com processo. Não sei de que estado que ele era. Acho que é Paraíba... E o cunhado dele morreu. Até ele disse que está com vontade de ir lá meter um processo em cima do candidato lá e tal, mas estava aqui com a família. Eu falei: “Ó, tem que tomar cuidado com esse pessoal lá. É muito perigoso esse pessoal”. Os caras matam só pra ver o tombo, né.

E o cara perdeu a vida. Falou errado, o cara... Coitado, analfabeto, acabou perdendo a vida. Isso é cruel. Não é fácil, não.

Então, é o que eu falei para você. O que eu vivi aqui, teve muita discriminação. Muita gente. Sabe aqueles caras meio ultrapassados? Que vão na igreja e só querem ficar rezando lá. Mas os padres aqui sempre foram muito claros. Por que, às vezes, a igreja hoje é muito mais vazia que a do Humaitá? O padre chama a dinâmica, eles colocam a verdade. Eles falam o que a gente tem que fazer, o que tem que ser. E diante do Evangelho, a gente se sentia compromissado. Tinha que fazer alguma coisa. E a gente cobrava das autoridades. Cobrava do prefeito, dos vereadores, cobrava melhoria no bairro. Tanta coisa para ser feita no bairro: praça, área de lazer, ônibus, passagem mais baixa, lombada.

Os padres de fora não se infiltravam aqui no meio. Então, os nossos padres é que comandavam. E eles gostavam, os padres aqui. O padre Mahon, muito bom... Aquele ali, o padre Otávio, que hoje é bispo, era muito bom também na época. Ajudava muito. Nossa! Aí, depois saiu daqui, virou bispo. O cara subiu para a cabeça. Já são outros quinhentos. (risos) Alguns mudam.

Eu tive propostas de outros partidos para sair fora do PT, para entrar em outros partidos e ser candidato. Mas eu não quis. "Ah não. Vou continuar no PT aqui mesmo". Eu não vou sair do partido, porque sendo candidato, você tem uma posição melhor, vai ganhar mais dinheiro e tal... se ganhar, né. Agora, por outro lado, muitos vão te odiar também. Porque, muitas vezes, você quer fazer um negócio e o outro não aceita. $\mathrm{O}$ outro vereador não aceita e acaba não aprovando. Você tenta, batalha, batalha, não consegue, e a turma vai ficar com bronca de você. Então, é melhor que ninguém fique com bronca de mim. Eu não vou participar da eleição, não.

Eu conheci o Miguel*. A gente trabalhava junto nos movimentos. O Miguel era muito dinâmico. É Miguel Arcanjo acho. Se eu não me engano, tem uma estação de ônibus lá embaixo que chama Miguel Arcanjo. O nome dele. Em homenagem a ele: Miguel Arcanjo. Ele era muito dinâmico. Ele discutiu por causa do PT. Por isso que mataram ele. Não sei se você ficou sabendo. Lá no Humaitá, discutindo com um cara, o cara pegou e matou ele. Eu conheci os filhos dele. Ele vinha trazer jornalzinho do PT no salão. E eu era assim: eu era do PT, mas ligado à Igreja. Eu vinha da Igreja e eu me liguei ao PT, mas fazendo parte da Igreja. Ele era do PT, mas era desligado da Igreja, não tinha infiltração na Igreja. E eu era infiltrado 
na Igreja. Ele ajudava muito os candidatos, viu. Ele andava distribuindo papelzinho para todo mundo, jornalzinho do PT... Falou do PT, era com ele mesmo. O cara trabalhava. Trabalhava, trabalhava, trabalhava. Foi uma pena matarem ele... Uma pena... Que ele era um cara muito trabalhador.

Teve curso de Teologia lá no Humaitá, que a gente precisou fazer. O padre pediu para a gente fazer. Porque eu já estava como Ministro da Palavra, e estava nas CEBs, tinha que fazer curso. Nós fizemos preparação lá no Coração de Jesus. Fizemos muito tempo o curso de Teologia aí embaixo, no Humaitá. Eles davam curso de Teologia para a gente aí. Ficamos fazendo muito curso. Há muito tempo, nossa! Isso aí em oitenta e pouco, 83, 84, por aí... muitos anos... Vinha cara de fora dar curso de Teologia para a gente. E nós fizemos por muito tempo esse curso.

E sei lá, foi um aprendizado muito grande para mim. Porque comecei a participar das CEBs, depois já caiu aquele negócio das greves gerais. Uma coisa engrenando com a outra.

Teve o encontro de Piracicaba, fiquei três dias. Então, o encontro, naquela época, foi ligado à seca do Nordeste. A nossa preocupação era para mandarmos ajuda para lá. Para aqueles irmãos que estavam necessitados. E tinha muitos das CEBs lá também. De que forma nós íamos levar para a sociedade a necessidade de ajudar esse povo? Aí, tinha gente de lá que passava os problemas para nós nesse Encontrão. Como é que estava sendo lá: gente passando fome, não estava chovendo, gente com extrema necessidade, um monte de coisas. Eu sei que foram três dias. Fomos na sexta e voltamos no domingo à noite. Eu fui representando a Região Leste. Fui eu e mais uma pessoa. Na Região Leste eram 9 paróquias. Hoje tem mais, né?

Então, a gente começou essa participação. Foi muito bom na época para mim, eu estava começando. Isso foi lá em 83. Eu estava caminhando fazia pouco tempo nas CEBs. Então, foi muito bom esse Encontro. Fizemos Encontrão em São Bernardo. Em São Bernardo, o Encontro, Ave Maria!, tinha umas 7 mil pessoas, no Vera Cruz. Foram de 6 a 7 mil pessoas! Foi depois de Piracicaba. Mas o Encontrão, Nossa Senhora! Eu lembro que nós fizemos uma peça, um teatrinho. E eu estava na organização também. Eu até lembro a música do teatrinho. Foi aquela do trigo. Como é que é? "(...) cio da terra a propícia estação... Debulhar o trigo, recolher a bagaço do trigo...". Foi aquela música. 'Cio da Terra'. Nós fizemos o teatrinho em cima dessa música. Mostrando a partilha, a forma da partilha. Então, foi um Encontrão muito rico. Foi um dos Encontrões que deu mais gente. E muito, muito bom! Foi muito maravilhoso esse Encontro.

Isso aí foi nos anos 80. Falou-se muito da seca do Nordeste. Foi falado da partilha. A coisa principal era a partilha. Ensinando o povo a partilhar, a ajudar um ao outro. Porque nas CEBs, mesmo na reivindicação que havia na prefeitura, a gente fazia sacolada direto também. Tinha muita gente necessitada na época. Muito desemprego na época. Os grupos se uniam e partilhavam. A gente nem levava na igreja. Partilhava com o pessoal, porque até no Grupo tinha gente que estava passando necessidade. Então, doávamos as cestas.

Todo grupo fazia uma cesta por mês, na época. A maioria. Tinha grupo que não fazia, mas a maioria fazia. E ajudava muito. Quer dizer, a gente tentava cobrar das autoridades e também ajudava aqueles irmãos mais necessitados. E foi muito bom. Muito bom. Os grupos estavam sempre cheios de gente. O povo animado!

Tinha uma participação boa de homem. Mas já era bastante mulher. Hoje, eu percebo que tem ainda mais mulher do que naquela época. Naquela época tinha mais homens participando. Para mim a coisa era normal. Eu até achava chato quando ia na casa do homem que o dono não ficava. Às vezes, nós íamos na casa do cara e o cara ficava no bar. Eu achava chato. Ficava até triste com isso aí. Mas eu me sentia bem, normal. Eu não tinha esse tabu de 
mulher e homem, não. Era levar a Palavra de Deus na casa das pessoas, principalmente daquelas pessoas mais necessitadas, com falta da Palavra de Deus. Não só necessitada de alimento.

Pessoas que não iam nem na igreja, através daqueles encontros nossos, começaram a enraizar, e começavam a ir na igreja, começavam a participar, a se envolver. MUITA gente participou da comunidade devido a isso. Se envolveu muito nos grupos quem nunca tinham ido, e depois começou a participar na igreja. Era muito envolvente.

O que manda nesses grupos, para ajudar, é a coordenação, é a pessoa ser muito humilde. A pessoa tem que se sentir muito humilde, nunca discordar da ideia de ninguém. Porque se a gente discordar da ideia de alguém, a gente está automaticamente tesourando aquela pessoa, a participação dela. Que ela vai se sentir envergonhada e não vai mais. Agora, se nós estamos no Evangelho, colocando o Evangelho no nosso dia-a-dia de hoje, e a pessoa tem uma resposta errada, o que é que você vai fazer? A gente ia colocar o que o Evangelho está querendo passar para a gente hoje. E aquela pessoa, da forma que ele falou, sem ninguém chamar a atenção dela, sem ninguém falar nada, ela vai perceber que o pensamento dela não estava correto, que ela estava pensando de uma forma diferente. E isso sem precisar falar que a pessoa estava errada. Então, você passava a palavra certa, mostrava, e aquela pessoa ia perceber sem ninguém reparar aquela pessoa. E ela ia continuar participando. Quer dizer, qual era o resultado? O resultado era o grupo lotado.

E tinha grupos que nego reclamava: "Vai pouca gente no nosso grupo, não aumenta, não aumenta". Por quê? Era por não saber conduzir o grupo, animar o grupo. E também por ter pessoas querendo se mostrar. Nas CEBs, quem anima, tem que ser humilde mesmo. Tem que ser humilde. Ele tem que ser o pior de todos. Mostrar-se mais baixo do que todos. Para deixar o pessoal à vontade.

Falar: "Eu estou aqui e eu sou como vocês. O que vocês sabem, eu sei menos ainda. Vocês sabem muito mais do que eu. Mas nós estamos aqui tentando nos consertar, tentando melhorar a nossa situação, na nossa cidade, no nosso país. A gente quer isso".

Então, sempre se colocando abaixo deles, do pessoal. Nunca se colocar superior. Se começasse a falar superior na frente do pessoal - porque é povo humilde -, ia deixar eles muito rebaixados. Ia deixar pequenininho. E, na verdade, nós éramos iguais a eles, mesmo. Não era nada mais.

Tinha um cara que era o braço direito. Nós dois. Nós dois fazíamos a Celebração. A turma adorava. Depois de um tempo, o cara não pega e vira crente! Virou a cabeça, virou da Cristã do Brasil. E até a amizade mudou comigo. Se eu torço para o Santos, eu não vou torcer para o Corinthians. Se eu torço para o Corinthians, eu não vou torcer para o Santos. Eu acho que eu tenho que ter um objetivo na minha vida: "o que eu quero". Se eu vim no mundo e os meus pais e meus avós confiaram na religião católica, por que eu vou querer trair a confiança do meu pai e da minha mãe, do meu avô, minha avó, do meu padrinho, e ficar mudando de religião? Estou traindo a confiança. E batizado existe um só, não existem dois.

Então, o católico muitas vezes, hoje, é o carismático. O carismático é muito bom. Eu não tenho que falar nada de carismático, não. Mas, a nossa aqui, os Filhos da Caridade, é uma Igreja mais progressista um pouco. Mas as missas se fazem tradicionais. É uma mente mais... mais avançada em pôr a mão na massa. Porque o carismático, ele é muito oração, muito oração. É importante. Segurou muito católico na Igreja. Eu não critico. Pelo contrário, eu acho muito bonito. Só que eu participo da tradicional. Da progressista. A nossa é a Igreja tradicional, mas tem uns padres que têm a mente evoluída. É uma pena não ter uns dez padres Mahon. Porque o padre Mahon mais novo era... não tinha padre igual a como ele é. Vixe, ele é muito bom. Então, depende muito do animador bom, onde a gente está, para as coisas crescerem. 
Eu na Igreja, antes, era descomprometido. Eu ia na igreja, rezava a missa. Rezar não, eu assistia, né. Não tinha muita participação. Eu assistia a missa. Depois que eu vim para cá, assistia a missa também. Mas depois de 79, em que um jovem me convidou para participar da igreja, no grupo de teatro, e que eu aceitei o convite, eu já não assisti só mais, eu comecei a participar. Houve uma mudança muito grande. Aí, eu comecei a perceber que eu tinha compromisso. Não era só ir lá assistir a missa e ir embora. Que eu tinha alguma coisa a ver com a sociedade. Eu tinha que ter mais envolvimento com as pessoas. Tinha muitas pessoas que não participavam da Igreja, e a gente precisava levar o Evangelho até essas pessoas. Mudou cem por cento. Mudou pra caramba.

Até então, o que eu participava lá no Paraná era ir nas missa aos domingos e sem problema nenhum. Nós rezávamos o terço também, um terço por semana nas casas dos vizinhos, nos sítios. Mas sem compromisso também. Rezava as Aves Marias, fazia oração. Mas nada comprometedor, que te comprometia a ir fazer alguma coisa, fazer uma visita. Nada disso, não. Quantas vezes que no grupo não tinha terço. Mas em vez, no lugar da ladainha, tinha o Evangelho. E no Evangelho tinha a discussão. Sempre colocando o Evangelho na nossa vida hoje, no que nós estamos vivendo. Vai ver a ligação que tem o Evangelho com a história de vida, com o que está acontecendo hoje. Muitas vezes, em reunião, no livrinho, vinha a história sobre o que aconteceu com uma família. E depois do Evangelho, a gente ia descobrir a ligação. Nos encontros, até hoje ainda, é colocado para a gente se comprometer com alguma coisa, no final: ou visitar um doente, ou fazer visita na casa de uma pessoa idosa, ou uma criança abandonada, ou qualquer coisa assim. Muita gente não faz, mas tem alguns que fazem. Ela cobra até hoje para fazer.

Mudou bastante a minha forma de enxergar Deus. A gente vê uma forma diferente. E eu só ia lá pedir perdão pelos pecados que eu tinha cometido na semana. E aí, depois que eu comecei a minha participação, eu já me comprometia mais. Eu ia vendo. Eu comecei a perceber que, diante de Deus, eu não estava fazendo nada. Pelo que Ele pedia no Evangelho, eu estava de braços cruzados. Eu tinha que fazer, eu tinha que me mexer, era hora de eu fazer alguma coisa. Então, você se sentia tocado. "Ou você vai ou você não está fazendo parte". Aí, você tinha que ir. (risos)

Aí, é quando começa a participação, a minha infiltração na política, no PT. Não era porque o PT era dos metalúrgicos nem nada, mas era um partido mais comprometido com a sociedade. É um partido do povo mais sofrido. É um partido que foi criado com a ideologia diferente dos outros.

A ideologia, é lógico que mudou muito. Era muito radical na época. Na época, o PT era radical demais. Não aceitava isso, não aceitava... Não aceitava se envolver com partido nenhum. Hoje eu vejo muitos partidos aí fazendo como aquela Marina*: o PT projetou ela, ela fez o nome, e depois ela abandonou, pulou fora do barco. Quase ninguém conhecia essa mulher. O que aconteceu? O PT colocou ela como Ministra do Meio Ambiente, ela fez até um bom trabalho, o mundo inteiro conheceu, e na hora que ela viu que criou uma asinha, opa! Né? Criou uma situação lá, pulou fora do partido, pulou num outro barco. São pessoas querendo aproveitar a oportunidade. Era super radical.

A mesma coisa do PT quando começou: era a mesma coisa, era radical demais. Quer dizer, se não tiver um envolvimento, uma união com os outros partidos, se não se unirem no governo... Você vê que o Lula é um cara super inteligente. Ele era radical demais, mas ele mudou pra caramba. O Lula, de quando começou para cá, opa, hoje ele é outra pessoa. Ele mudou. Então, a gente tem que aceitar a renovação. A gente tem que ser renovado a cada dia que passa.

É como na minha religião: eu era católico e ia na missa, e eu me renovei. Mudei a relação. Hoje eu vejo ainda que, conforme o que eu fui, o que eu fiz, hoje eu estou de braços cruzados. Hoje eu estou fazendo bem pouco. Mas eu já trabalhei muito, muito, muito na 
Igreja. Quantas vezes que eu saía daqui e ia celebrar lá no morrão, de noite. Saía daqui de casa 7 e meia, já escuro, e ia subir lá naquele Morro da Kibon. Não tem aquele morrão, lá? Nossa, a minha família ficava apreensiva.

"Ô filho, pelo amor de Deus, está cheio de bandido. Você vai fazer o quê lá?".

Eu: "Não mãe, eu tenho um compromisso lá. Eu tenho meu encontro na casa".

"Não, pelo amor de Deus. Não vai, não vai...".

"Não, eu vou".

Eu ia lá, fazia reunião com o pessoal, marcava para a outra semana em outra casa. Eu animava um grupo lá e outro aqui perto. Eram dois grupos que eu ficava animando: um no morro, lá, e outro aqui. E lá a gente já organizava o pessoal para reivindicar, para colocar luz, esgoto. O pessoal ia lá, muitas vezes, de lamparina. Não tinha nem luz. A gente tentava abrir a mente do pessoal para lutar, para organizar e reivindicar. Para uma melhoria do bairro. E graças a Deus, rapaz, eu fiquei lá quase dois anos trabalhando, e nunca ninguém me parou, nem roubou. Nunca. Ia a pé de noite e voltava, 9 e meia, 10 horas, sozinho de lá. Graças a Deus. Minha família ficava com muito medo.

E quantas vezes também, ia participar, o meu irmão mesmo me falava: "Ah, você vai nessas rezas. Essas rezas aí não estão com nada". Eu falei: "Pode não estar para você, mas para mim está. Diante de Deus eu estou fazendo alguma coisa. Para você não, mas diante de Deus eu estou trabalhando". Eu nunca deixei me abater por que as pessoas falavam alguma coisa. Nunca.

Atualmente, eu estou no Sagrado Coração de Jesus, no Apostolado, eu faço parte da Acolhida, eu faço parte dos Ministros das Exéquias - exéquias é quando vai encomendar o corpo -, e Ministro da Eucaristia. Já fui Ministro da Palavra mais de dez anos. Teve uma vez que o padre Miguel falou: “João, dá para você quebrar o meu galho?”. Faltando 1 hora para a missa. Nem 1 hora, uns 40 minutos.

Eu falei: "O que é, padre?".

"É que eu caí de moto, João... Estou todo ralado... Faz a Celebração pra mim. Eu ia rezar a missa 6 horas. Faz pra mim?".

"Pode deixar comigo".

Aí eu, despreparado de tudo, tinha que correr, catar folheto... Eu ia ler o Evangelho para fazer a homilia. E ele arrebentado de última hora. E eu, de última hora, pegar e fazer a Celebração, no último minuto.

E hoje eu estou ocupando também o Conselho Administrativo.

Eu fui do Grupo de Jovens. Muito atuante, sabe. Jovem, atuante, era um puta grupão. O nome do grupo era 'Juventude Geração'. Por que o nosso grupo durou muito? Nós não aceitávamos panelinha. Não tinha um cara assim: "Esse é o manda-chuva do grupo". Não. Cada encontro era um jovem responsável. Hoje é você. Aí, era ele. Aí, no outro encontro, nós botávamos: "Ó, você vai".

"E aí, vamos ver um passeio?".

"Vamos".

Aí, a gente via alguma panela, nós entrávamos no meio. Opa!, entrávamos no meio e não deixávamos ter panelinha. E nós dançávamos quadrilha. As quadrilhas mais bonitas que tiveram na São Geraldo fomos nós que fizemos. E os teatros mais bonitos. Teatro do Cristo pregado na cruz, de São Geraldo, Manguito... Tudo envolvido na igreja. Mas a gente fez teatro pra caramba, hein!

O sindicato, uma vez, veio dar uma palestra na pracinha. Veio o carro do sindicato, tudo aqui. Do PT. E chamavam a gente para fazer teatro e a gente veio no carro do sindicato.

Rapaz, a participação do Grupo de Jovens foi maravilhosa! Nossa Senhora! Muito, muito, muito bom. 
Esse nosso grupinho de jovens, nós fazíamos baile na casa um do outro, nós nos divertíamos, nós íamos fazer passeios, nós íamos para Paranapiacaba, íamos para um monte de lugares, e passeava, e passeava de trem, e passeava de um lado para o outro, e trabalhava na comunidade e se encontrava todo domingo.

$\mathrm{Eu}$ participava das CEBs, eu participava como ministro, participava do Juventude Geração. Todo domingo era envolvido na igreja. E em dia da semana ia também.

Eu entrei como ministro desde 83. Ministro, a cada três, quatro anos, muda, pode renovar. Fiquei ministro 3 anos. Aí, você pode renovar para mais 3, e dá 6. Aí, você tem que sair para dar lugar para outro. Só sei que eu vim envolvido de Ministro da Palavra, Ministro das Exéquias, Ministro da Eucaristia... e venho rodando, desde 83 até agora. Ah, da Liturgia eu também participei por muito tempo. Agora eu não estou mais na Liturgia por falta de tempo. Liturgia, animar as missas, fazer a leitura, os comentários... por muitos anos eu fiquei. Muito, muito, muito. Quantas vezes que não tinha nem Coral, e a gente ficava aprendendo com o pessoal: "Vamos cantar assim. Vamos lá. A turma de cá canta um tanto, a turma de lá canta outro tanto". E animava e a turma ia. Depois ia fazer a Celebração e ficava aquela missa bonita. Todo mundo participava sem Coral. Aquela coisa bem simples.

Então, eu sei que foi uma participação muito bonita que a gente teve aí na São Geraldo. Muito bonita. Hoje é que eu falo para você: com essa situação que eu estou aí, eu estou me sentindo de braços cruzados, acomodado. A gente não vai quase na prefeitura cobrar mais nada. (risos)

Apesar de que o bairro melhorou, né. E chegou água, e chegou luz, chegou asfalto, chegou ônibus, chegou tudo. Só essas passagens que estão um absurdo, né. A passagem está absurda hoje em dia. O tancão, que era uma área de lazer, agora está aí abandonado. Não tem lazer para o pessoal do bairro... A gente não reivindica mais nada... Os prefeitos estão sossegados. Não tem ninguém pegando no pé deles. Não tem ninguém instigando. Não tem ninguém, então...

E, depois de casado, o padre convidou a gente para participar do Encontro de Casais, para dar Curso de Noivos. A minha ex-mulher não topou. Convidou a gente para ser Ministros de Batismo, ela não topou. É fogo, rapaz, você gostar de uma coisa, querer, e quem está do seu lado não querer. É cruel. Fazer o quê? Eu sempre procurava fazer o melhor para a gente se dar bem. Mas é cruel...

E eu aprendi muito com o padre Alfredinho também. Eu aprendi muito com ele. A humildade do padre Alfredinho. Muito, muito bom. Era um padre que foi tudo de bom.

Ah, a gente criou também o... como é que chama? O padre Alfredinho que criou... o Servo Sofredor... Então, como é que é o nome? Participei tanto tempo. E ainda hoje. Ainda pega uma migalha de dinheiro. Era grupo de sete... O PAF. 'Porta Aberta aos Famintos'. E nós tínhamos um grupo. Eu participava do PAF. E tem as mulheres. Até hoje a gente se reúne, lá do PAF. Eu ainda pego o dinheiro do PAF. Hoje, ajudando, tem eu, uma mulher e um senhor. A mulher, tem meses que ela traz dinheiro, tem meses que ela não traz. Então, ajuda uma merrequinha.

Nós mandávamos dinheiro para o Nordeste. Primeiro, a gente ajudava com uma boa quantidade. Uma vez por mês, fazia uma missa, uma celebração. Aí, pararam de fazer. Agora, só assim, quando alguém precisa. Aí, a gente ajuda. Vai juntando um dinheirinho... Até a gente ajudou com dinheiro um carinha que estava numa pior aqui, para fazer uma casinha lá no João Ramalho. Nós ajudamos a fazer um barraco. O cara estava sem lugar para morar. Fizemos um barraco para o cara, demos bastante dinheiro para ele comprar as telhas, comprar 
uns negócios lá. Eu participo desse grupo também, do PAF. Mas está, assim, engatinhando, sabe. Mas é uma coisa criada pelo padre Alfredinho.

O padre Alfredinho... esse era humilde, humilde. O padre Alfredinho... Eu convidava ele para comer na mesa, ele pegava e sentava no chão. Comia no chão. (risos) Ele era o maior barato. Nossa Senhora! Quebrava a bunda de qualquer um. (risos) Padre Alfredinho não gostava de luxo, não.

Teve uma vez que estava tudo certinho para passar a noite inteira lá, fazendo vigília na casa dele, lá na favela. Aí, a gente chegou meia-noite, falou: "Ah, vamos comer o sopão". Comemos o sopão e fomos lá fora para tomar um arzinho. Lá fora da capelinha, lá em cima. Aí, um cara com a 'doze': "Todo mundo pra dentro!". Um bandidão lá fora com uma doze, esperando neguinho passar lá. "Entra todo mundo pra dentro!”. (risos)

É mole? Um lugar feio, uma viela. E minha ex-mulher, aquela vez, não queria que eu fosse: "Você não vai, você não vai. Você vai ficar". Ela estava grávida de 6 meses. E eu estava comprometido: "Eu tenho que ir. Pelo amor de Deus, eu tenho que ir".

"Você não vai. Vai me deixar aqui?!".

"Mas tem as crianças com você. Tem o Jhonatan* com você". Ela estava grávida da menina.

"Eu não quero que você vá! Eu não quero, eu não quero". Foi uma discussão aquele dia. Mas eu fui. Nós fomos. Ia ficar a noite inteira, mas fiquei até 1 hora da manhã. Aí, 1 hora da manhã, eu peguei uma pessoa de lá de dentro, que conhecia todo mundo, para me tirar fora da favela. Ele veio comigo e o cara com a doze não estava mais lá. Eu já estava com medo, né. O cara com a doze lá... Ele botou a gente pra dentro para ficar lá tranquiilo, no movimento dele. Aí, eu peguei e sai de lá. Cheguei em casa umas 2 horas da manhã. (risos)

O padre Alfredinho, Nossa Senhora! Fazia a 'Passeata da Paz' lá. Era uma matança de gente, rapaz... Depois o Alfredinho ficou um tempo lá e diminuiu pra caramba a matança. Ele passou muita humildade para o pessoal. Muito, muito. Um padre muito bom, muito bom.

Quantas vezes que eu larguei o serviço aí e ia na prefeitura, na Câmara, para cobrar os vereadores lá, na hora de votar. Foi muito boa a participação. Pena que parou. A gente tinha o nosso braço direito que era o Mahon. Mahon era a nossa luz. Era o nosso ponto de referência. Era a nossa luz. Ele é que nos reforçava, e ele fazia reunião com a gente, dava força para a gente, nos alimentava na espiritualidade. E nós encarávamos. A gente se envolvia na igreja, com a política... seguimos um caminho político. A gente procurava organizar as pessoas eram muitas pessoas desorganizadas -, e tentava passar para a cabeça delas mudanças. Tinham muitos que ignoravam, que não aceitavam, mas a gente sempre procurava levar para o caminho bom. Mas foi bom.

Até teve, depois, a minha separação. A comunidade, a igreja, me fortaleceu. Teve um momento que eu me senti sozinho. Tiveram muitos momentos em que eu estava aqui triste demais, mas não tinha um da comunidade para vir aqui e dar uma palavra amiga para mim.

Às vezes, você está sozinho, você olhava assim... caramba... era um barulho, as crianças, né. "Pai" daqui, "pai" de lá, "vamos brincar de esconde-esconde", quase toda noite brincava de esconde-esconde... de repente, acaba tudo indo embora, bicho... É... Se o cara não estiver bem preparado, em 3 meses fica lóki. Fica lóki até lá. Fica doido da cabeça.

Graças a Deus eu encontrei muita força. Me superei. Soube superar. A igreja me ajudou muito na minha caminhada. Eu vi o sofrimento de outras pessoas... Você vê o sofrimento de muitas pessoas aí e percebe que a gente vive no Céu. É só a gente sair, igual a gente ia nos grupos, nas casas das pessoas. E ver o testemunho de vida deles. Você ver o que é a humildade, a simplicidade. Você acaba valorizando mais o pouco que você tem. Você acaba vendo que a gente não sofre nada. Tem gente que é dez vezes pior que a gente. A vida é essa... Sozinho você não vai resolver o problema do cara. É meio difícil. Não é fácil, não. 
São altos e baixos. Um monte de coisas. Se você não estiver bem preparado, você abandona o barco. Abandona o barco e vai viver uma vida diferente. Quando o cara me chamava para dar um rolê, para ir nesse lugar, nisso e naquilo, naquele outro... Eu: "Não, não. $\mathrm{Eu}$ tenho compromisso na igreja. Eu tenho que assumir o meu compromisso". Não ia. Eu deixava tudo para ir na igreja. Sempre deixei. Mas valeu a pena, né? Valeu.

Porque eu tive, nos meus altos e baixos, a época que a minha mulher... minha exmulher me largou, passou um ano e pouco e minha mãe faleceu. Passou mais um tempo, ela me enganou, foi embora para os Estados Unidos e levou meus filhos embora. Fiquei um ano e três meses sem vê-los. É uma série de coisas. E se você não for bem preparado psicologicamente, se você não for bem preparado em Jesus Cristo, você cai. Você cai. Você tem que ter um espírito muito forte. Senão você vai para baixo. Vai para a lona. Vai mesmo. E para voltar, meu...

Agora eu estou indo cortar cabelo de um pessoal que vive na rua. A cada trinta dias, quarenta dias, nós vamos cortar cabelo lá no Ana Maria. Aí, todos os caras de quem eu vou cortar cabelo, eu fico de ouvido no cara, tentando catar alguma história dele, história de vida. A maioria é separado de mulher, rapaz! A mulher largou. A maioria. O cara apaixonado. Caiu na pinga. Caiu na pinga e hoje nem vê filho mais, cai na rua... Vira um mendigão aí, jogado. $\mathrm{O}$ cara que tinha emprego, trabalhou em firma automobilística, 5, 10 anos... o cara de boa situação. O cara foi perdendo tudo o que tinha e ficou na lona, decepcionado. Quer dizer, gostava demais de uma mulher, ao invés de procurar outra... não. Ele preferiu ficar sofrendo, bebendo, enchendo a cara. Perde tudo o que tem a maioria dos caras de quem eu corto o cabelo. Família. Problema de família. É, meu, é fogo.

$\mathrm{Eu}$ vejo assim: desde pequenininho, eu tinha uma vocação muito grande de participar da Igreja. Participar como coroinha eu nunca tive oportunidade. Morando na roça lá, e eu ficava com uma vontade danada de participar da Igreja e de ser coroinha e tudo. Então, veio aquela vocação de pequenininho, de estar infiltrado. Era mais eu e minha mãe na igreja. Minha mãe era a luz que sempre me ajudava e me encaminhava. Mas eu achava que eu tinha que passar por tudo isso aí, ou mais. E eu pensava que eu não ia nem ter oportunidade. Pois desde pequeno lá, que eu perdi a oportunidade de ser coroinha, e depois já vim rapazinho para cá. Eu falava: "Agora não vai ter mais nada para eu fazer na igreja".

Mas foi um engano. Aqui eu vi uma porta bastante aberta para mim, onde eu me encaixei, onde eu me enturmei, onde eu vivi, onde eu aprendi. E eu vi que tudo aquilo que aconteceu, e acontece - e hoje a minha participação está bem mais fraca -, tudo isso aí que eu vivi valeu a pena, vivi com amor, eu fiz com amor. Tudo o que eu fiz foi com amor. Nada assim de querer tirar proveito. Porque se eu quisesse tirar proveito, eu tinha saído candidato a vereador, com certeza. Eu podia até não ganhar, que é difícil, mas que ia passar raspando, ia. E tirar proveito. O que eu achava é que tinha que melhorar a situação do povo. Eu me preocupava muito com o povo. Não muito comigo. E aí foi indo.

É pena não ter feito mais ainda do que eu fiz. E se tivesse que passar por tudo de novo, eu passaria. Eu não pretendo parar nunca de participar. Acho que mesmo do jeito que eu estou, vale a pena. Eu faço visitas para alguns doentes. Isso aí é muito importante: você ouvir a pessoa, conversar. Eu via a necessidade das pessoas de ter alguém ao lado delas, que ouve elas. É muito importante isso aí: você ouvir o doente falar, desabafar. E toda essa caminhada valeu a pena.

É lógico que no meio você tem decepções. Mas você não está fazendo em função daquela decepção, você está fazendo em função de servir a Deus. E servindo a Deus você vai ter barreiras no meio. Que nem aquela do padre Otávio, que virou bispo, virou "Dom" Otávio. (risos) Eu lembro outro atrito que eu tive com o padre Alaor. Aqui na São Geraldo mesmo. Eu tive atrito com ele. Que o padre Mahon, que era o pároco, foi viajar. E ele (padre Alaor) era 
padre recém-formado. O padre Mahon foi viajar e deixou a gente, do Conselho. Tudo o que se fazia na igreja, passava pelo Conselho. Aí, deixou o padre Alaor durante um mês. Na hora que nós fomos na outra reunião do Conselho, foram as mulheres que estavam no Conselho Administrativo e ele falou: "A turma da cooperativa está deixando a sala aí uma zona, tudo cheio de papel, sujo, bagunçado".

A mulher: "Mas que cooperativa?".

"A cooperativa, a turma está fazendo doce aqui, aprendendo a fazer doce no salão".

"Mas a gente, do Conselho Administrativo, não sabe nada disso. Como a turma está usando o salão? Não foi pedido, não foi nada...".

Aí, o padre Jorge falou assim: "Opa! Eu que decidi. Eu sou padre e decidi. Eu decidi que fizessem aí, para ensinar a turma a fazer doce, a cooperativa".

Eu falei: "Não, eu sei que você é padre. Você é padre mas não é o pároco. Você é padre vigário que está aqui, substituindo o padre Mahon...".

"Então! Eu estou substituindo, eu posso decidir".

Eu falei: "Não é bem por aí, que aqui existe um Conselho. Quando vai vir dar curso de tricô, ou qualquer curso que tenha aqui, é tudo passado pelo Conselho. Agora você toma uma atitude de um monte de gente vir aí, está gastando água, está gastando luz... Estão colaborando?".

"Não. Eu que mandei. Não precisa colaborar, não".

"Então, a igreja tem que pagar água, tem que pagar luz, tem que fazer um monte de coisas e você decidiu?!?".

"É, fui eu que decidi! E acabou!".

"É, mas do jeito que você está falando, você está bancando. Então, não precisa do Conselho Administrativo. Para quê? Se você é o rei da cocada, manda aí?!".

Ih, rapaz. Nós quase saímos no tapa. Nós só não saímos no tapa porque entraram dois seminaristas no meio lá.

E eu falei: “Ó, meu, aqui você é homem igual a mim”, eu falei. Nós estávamos no salão. "Você, lá dentro da igreja, tudo bem de você consagrar, você é o papa. Aqui você é homem igual a mim, e eu exijo que você me respeite. Você tem que me respeitar".

Ele falou: "Você também me respeite".

Ele levantou, eu levantei, e a gente ia se pegar na porrada. Opa! O que é isso? Folgado do cacete. Estão tendo as coisas na igreja, nós somos do Conselho Administrativo e não passa nada na nossa mão? A turma ficou tudo quieto, meu. Na outra reunião já era o Mahon, não era ele. Eu falei: eu não vou desistir nunca, eu não vou pular fora do barco, porque ele está aqui por uma passagem, eu também estou. E se a gente está aqui para servir, se ele está servindo, eu também estou. Então tem que ter mesmo essa discussão, esse diálogo. Tem mesmo. Não é porque eu discuti com ele que eu vou me afastar.

Nas missas eu já ia lá atrás mesmo. Fiquei invocado. Não queria muito ficar lá na frente. Ficava lá atrás.

Aí, na hora da missa, ele foi lá um dia, me catou: "Ô João, vem aqui na frente".

"Ah não, aqui está bom demais. Está dando para ouvir muito bem".

"Não, eu quero que você venha aqui na frente... O seu lugar é aqui... Você me desculpe por tudo o que aconteceu".

"Não, não, tudo bem. Não tenho raiva de você, não". E já era. (risos)

É assim, rapaz. São altos e baixos. Quer dizer, era uma coisa que não precisava ficar se preocupando. Mas eu acho que se na igreja existe uma regra, tem que seguir aquela regra. Então, não precisa ter Conselho, ué... Se o padre é o rei da cocada, resolve tudo sozinho, para quê Conselho Administrativo? Não precisa. 
Então, se fosse para discutir, discutia até com o padre. Eu discuti uma vez com o padre Mahon também. Eu fiz a Celebração e no final ia ter um almoço comunitário no domingo seguinte.

Eu falei assim: “Ó, pessoal, vai ter almoço comunitário domingo que vem. TODO MUNDO está convidado para vir almoçar. Mas todos vocês trazem alimentos. Quem puder trazer mistura, traz; quem puder trazer arroz e feijão; quem quiser trazer pão de casa, traz; para nós todos comermos. Senão, como que a igreja vai servir?".

Convidei todo mundo. Ah, já correram contar para o padre Mahon que eu convidei toda a comunidade para ir comer lá. Aí, o padre Mahon veio aqui no salão. Pegou o carro dele e veio aqui: "Ô João, você está mandando na igreja agora?".

Eu falei: "Não. Mandando na igreja por quê?".

"Você convidou todo mundo para ir lá comer. Você vai dar comida para todo mundo? Então você leva comida para todo mundo. Aí, você convida. Depois que você levar comida para todo mundo comer, aí você pode convidar. E eu não dei essa autoridade para você convidar".

Eu falei: "Padre Mahon... você me convidou para almoçar lá domingo que vem, porque é almoço comunitário. Como que é almoço comunitário se eu não posso avisar na missa?".

"Não é. É dos grupos que participam da...".

Eu falei: “Ah, gozado, né, padre Mahon?!? Para pegar dízimo, pega de todo mundo da comunidade. Mas na hora de uma festinha, só o grupinho fechado? Você não fala que a igreja é aberta para todo mundo? As CEBs é aberta? Porque agora a gente pensar só nos nossos grupos?”.

"É, que não sei que...".

Eu falei: "Então, eu não vou. E outra, todo mundo que eu convidei, eu mandei levar as coisas". Mas é que encheram a cabeça dele, sabe. O padre Mahon é muito bom. É que encheram a cabeça dele e ele veio e desabafou tudo em cima de mim.

Eu falei: "Eu não vou".

"Agora que você convidou todo mundo, você vai, para levar comida para a turma!". vou".

Eu falei: "Padre Mahon, se faltar comida, você me telefona que eu levo. Mas eu não

Aí, teve festinha e tal... Aí, diz-se que todo mundo que foi, levou, sobrou comida pra caramba. Aí, eu cheguei nele, umas duas semanas depois. "E aí Mahon, faltou comida na festinha?".

"Não, sobrou bastante. Por que você não veio? Faltou você".

Eu falei: "Lógico. Se na igreja não cabe aquela turma que eu convidei, não cabe eu também. Porque eles pagam dízimo igual a mim. Porque cabe eu e não cabem eles? Eu acho que nós todos aqui somos abertos, temos que ser abertos com tudo mundo".

"Ah, João, esquece isso aí... Sobrou bastante comida".

"Então, precisava o senhor fazer isso comigo? Não precisava você ter feito isso comigo, ter comido o meu rabo de graça. Eu convidei o povo da comunidade, o povo que vem na missa. E é o povo que traz as coisas. E é o povo que ajuda com o dízimo".

Aí, ele falou: "Não, não, deixa isso de lado. Esquece".

Eu também não liguei porque ele... coitado, é gente, né.

Você participa de comunidade, né? Você sabe como é que é. Tem cara que tem uma dor de cotovelo do caramba de você. Se puder ver você debaixo do pé, eles pisam no pescoço, dentro da igreja... Eles pisam no pescoço. Você tem que rezar por essas pessoas, para o anjo de guarda deles, para ajudar...

Eu estou lá não para me aparecer, é para ajudar... Se fosse para me aparecer, ia num programa, ia no teatro, ia fazer show, qualquer coisa. Isso é aparecer. Mas na igreja a gente 
tem que participar com AMOR. Primeiro de tudo ter amor no coração, senão eu vou assumir alguma coisa assim?

Tinha uma mulher na Acolhida, que eu chamei o padre Miguel - o padre Mahon não estava. É a dona Loreta.

Então, assim: "Ô, padre Miguel, quero conversar nós três".

"O que é, João? Pode falar".

Falei: "A dona Loreta está expulsando muita gente da Igreja São Geraldo. Ela não sabe tratar as pessoas, ela é áspera, não tem educação para conversar com as pessoas, maltrata, e muita gente está saindo daqui e indo lá na Nossa Senhora das Graças, lá embaixo.

Aí, o padre: "Poxa, dona Loreta, por que você está fazendo isso?".

"É mentira do João. Que nada! Sabe o que o João quer? Ele quer ver as mulheres aqui dentro da São Geraldo de mini-saia. Quer subir lá no altar e ficar olhando a bunda delas. Sei o que ele quer. Ele fica de olho na mulherada".

Eu falei: "Não, dona Loreta. A senhora está enganada. Se eu quisesse olhar bunda de mulher eu ia à praia. Lá está cheio de biquíni. Está cheio. Eu respeito muito a nossa comunidade, a nossa igreja. Então, a senhora tem que saber tratar melhor as pessoas para nós não perdermos tantos fiéis como estamos perdendo".

Mas é gratificante o que aconteceu. Tudo, tudo, tudo. É muita discussão, é muito jogo de empurra, muita política dentro da igreja e um monte de coisas. E tem gente que, às vezes, tem dor de cotovelo de você, mete a lenha, fala um monte. Você trabalha, trabalha, trabalha, e o cara fala mal de você. (risos)

Eu vou falar a verdade: eu queria viver de novo a passagem no Grupo de Jovens, os teatros, a participação, a união que a gente tinha. Eu adoraria viver isso de novo. A minha trajetória de participação lá nas cobranças, da vida política, se eu pudesse viver isso hoje, eu viveria de novo. Isso tudo o que eu passei.

O que mais me influenciava era o Grupo de Jovens mesmo. As CEBs - como era aplicada - eu também gostaria de viver de novo. Aquele povo unido, o povo querendo melhora, eu gostaria de viver de novo. Mas mais, mais mesmo... e tudo foi bom... mas o Grupo de Jovens foi tudo de bom: os teatros, a nossa união, a nossa participação, a nossa arrecadação de dinheiro... A gente saía pedindo as coisas nas casas. E fazia festa, vendia na festinha e dava dinheiro para a igreja. Um povo unido assim! Não tinha NINGUÉM diferente do outro. Era tudo igual. Cada um tinha o seu valor. Não tinha um mais valorizado que o outro. Então ia, caminhava. Foi muito bom. Eu participei do Grupo de Jovens até casar. Até 89.

Eu não me arrependo de nada do que aconteceu. Pelo contrário, se eu pudesse viver aquilo que eu passei, eu viveria de novo. Porque foi muito bom isso aí. Uma marca registrada que vale a pena.

Mesmo com a parte sofrida. Porque se não tiver sofrimento, acho que não é tão bom, né. O negócio é bom quando tem sofrimento, a luta. Você sofrendo, aprende. Você acaba aprendendo melhor. Se você tiver tudo na mão, tudo certinho, ah!, vai lutar para quê? (risos)

A gente vem lá daquela caminhada, lá do fundão. Acho que eu já falei desde o primeiro dia. A minha caminhada lá da roça, aquela vida sofrida. Que talvez você tivesse um sonho, um objetivo. E, às vezes, no caminho, ele desvia, você não consegue ter aquele objetivo. Talvez você nem sonhasse que aquilo tudo que ia acontecer na sua vida, acabou acontecendo. Que eu nem sonhava que ia sair do Paraná e encontrar uma igreja, uma comunidade, um povo acolhedor, igual ao que eu encontrei aqui na São Geraldo. 
Passou um momento na minha vida que eu tive vontade de entrar na política. Mas eu não entrei para não ter crítica em cima. Porque se eu entrasse na política, com certeza a turma ia falar que aquele trabalho meu é tudo em vão, que aquele trabalho que eu tive na comunidade era para me aproveitar. Então, como eu tive esse trabalho na igreja, para não ficar com essa culpa nas costas, eu não entrei na política. Por causa disso. Mas que eu tive vontade de entrar... Não para ficar rico... mas para se voltar mais ao povão... lutar mais pelo direito do povo sofrido. $\mathrm{Na}$ época, era verdadeiramente isso aí mesmo: para ajudar o povão que estava numa situação difícil nos bairros.

Foi uma coisa que eu deixei de concretizar na minha vida só para não levar o nome, para não ficar em vão o meu trabalho... Para o meu trabalho ficar em pé, concretizado, em tudo o que eu fiz, eu não podia entrar na política. Se eu entrasse seria em vão. Ficaria em vão. Porque nego ia me ver com outros olhos.

Fiquei com os meus pais, cuidando do meu pai e da minha mãe. A minha grande preocupação era o meu pai e minha mãe. O bem estar dos dois. Além da comunidade - que eu ia e tudo, que fazia tudo -, eu era focado no pai e na mãe, para dar o de melhor para eles dois. Sempre ajudando eles.

O que eu podia fazer para eles, eu fiz. Então, o meu grande objetivo era cuidar do meu pai e da minha mãe até o último dia de vida deles. Dar o do melhor para eles. Ajudar, levar em médico... o que precisar de mim eu estar do lado.

E a comunidade também. A comunidade crescer, a melhora do bairro. A preocupação com a melhora do nosso bairro, para as coisas ficarem melhor para mim também. Não só para os outros, como para mim. Tendo tudo no bairro, para nós era bem melhor. Que eu usava só ônibus, porque não tinha carro. Pegava o ônibus. Até que eu falei para você aquele dia das lutas, do preço das passagens do ônibus. A gente lutava muito porque eu pagava também. Quer dizer, para mim valeu. O pouco... um centavo, dois, três que diminuiu na passagem, foi uma vitória. Foi um fruto do nosso trabalho, da luta. Então, os panfletos, nós distribuíamos. E, às vezes, a turma discriminava a gente, e criticava.

E a participação na igreja também, quanta gente que não critica. "Eu vou lá acreditar nessa turma... Deve ser uma turma de sem-vergonha!".

O cara veio no salão: "Ô João, e o batizado? Você está pegando o dinheiro do batizado? E a igreja lá, você está metendo a mão naquela igreja lá, hein. Você está metendo a mão".

Eu falei: "Olha, se você pensa assim, eu estou. Por que você não vai lá participar com a gente? Vai lá".

"Eu não. Só tem malandro lá".

É fogo, mas você é discriminado pra caramba.

O cara tira um barato, tira sarro e fala: "Olha, eu vou falar a verdade, eu vou lá na igreja, mas não acredito em você não, meu".

Eu falei: "Não, não é para acreditar em mim. Está completamente errado acreditar em mim. Você tem que acreditar em Deus, rapaz. Quem salva é Deus, não sou eu, não. Não precisa acreditar em mim. Acredite em Deus. Eu só convido você para ir lá, ouvir a Palavra, participar com a gente".

"Vou nada. Você...", ele não podia ver eu trocar de namorada, "arruma uma mulher aqui, outra lá, não pára com namorada. Eu vou acreditar em você nada, meu".

Eu falei: "Não. Acredite em Deus que está bom demais. Não precisa acreditar em mim, não. Acredite em Deus que está ótimo. Acredite em Deus e faça a sua parte, e vá na igreja". 
É... a turma é fogo, rapaz... Se você for no papo dos outros, você abandona tudo. Chamar para ir, não chama, não, mas... coitado. As velhinhas convidam, coitadas. "Ô, João. Vai ter terço lá em casa". Até hoje.

Esse negócio que você está fazendo comigo, esta entrevista, está sendo bom. Porque eu estou tendo a oportunidade de me abrir e contar o meu passado. Sabe como está sendo? Você vai numa formação. Você escreve na formação, tá, e fecha o caderno. Aí, outro dia você vai na reunião. Você faz a reunião, tal, e escreve tudo lá e fecha o caderno. E vai indo, vai indo, desse jeito, sabe. Você nunca abre o caderno para ver aquele dia, o conteúdo daquela reunião. Você nunca vê isso aí, o que foi falado, o que teve naquela formação. Você não abre mais o caderno para ver o que aconteceu naquela formação, o que tinha lá, o que foi colocado. E isso aí que eu estou passando para você, é uma forma de eu te abrir esse caderno. Ter aberto de novo e lembrado... não tudo, mas parte, o mais marcante. A parte que mais me marcou. Isso, para mim, foi muito gratificante. Essas três noitadas que a gente teve... (risos) Você me entrevistando, é uma forma de eu me abrir. Não só contar negócio da Igreja, mas da minha vida também.

Foi lá, desde pequenininho, né. Desde pequenininho que eu comecei a trabalhar na roça lá, com 7 anos. Pequenininho. Sei lá, eu já te contei no começo, quando o meu pai corria atrás da égua para pegar ela para buscar a parteira e fazer o meu parto. Precisava andar uns 4 ou 5 quilômetros de carroça, e a égua ficou correndo no pasto, correndo, correndo, ficou quase uma hora para pegar ela. Na hora que ele pegou, trouxe, que foi pôr na carroça, ele foi lá dentro de casa, chegou lá, eu já tinha nascido, estava do lado da mãe. Só faltava cortar o umbigo. (risos) Foi lá buscar a mulher para cortar o umbigo. Então, essa história toda da vida da gente é muito marcante, é muito gratificante a gente revelar.

São coisas, assim, que talvez você até esquece, mas você perguntando a gente relembra. Tem muitas coisas boas que eu esqueci. A gente acaba esquecendo muitas coisas bacanas que aconteceram na vida da gente. Momentos difíceis, que talvez a gente passa também. Às vezes, você passa um momento financeiro difícil, momento de doença, um monte de coisas. Que aí, a minha mãe sofreu muito com diabete, pressão alta. Eu tenho uma irmã paralítica, eu não sei se eu falei para você. A VIDA INTEIRA paralítica. O meu pai e minha mãe criaram ela desde pequenininha, assim, numa situação difícil lá na roça. E trouxeram aqui para a cidade, tendo sempre na mente para ela não passar fome, sempre muito bem cuidada.

Então, era uma vida de pobreza mas, em volta da pobreza, com muito amor, muito carinho, rico de amor. Era uma vida pobre, que nós vivíamos e sempre vivemos, mas que tinha uma riqueza em amor. De tratar com carinho aquela pessoa doente. Criar, mesmo ela doente, com a paralisia cerebral que ela tinha, e procurar fazer o melhor para ela sempre. Sempre cuidar de levar ela no médico, tratar bem ela, dar banho todo dia, cuidar, trocar a roupa de cama, trocar a roupa... Então, é um monte de coisas. Um monte de coisa boa e de exemplo que a gente tem de pai e de mãe. E de irmãos também, que sofreram muito junto. E a gente é família tradicional, assim, que sempre fazia terço em casa. Sempre fez. A minha mãe era uma mulher muito religiosa. Ela faltava dar o coração para as pessoas. Ela gostava de doar as coisas.

Então, você vendo aquela caminhada, aquele exemplo, você quer seguir também. Você quer seguir. Um irmão participa mais, o outro não participa. O outro quer só ir na missa, e mais nada. Mas dessa vida a gente nunca leva nada. O importante é que a gente participa. $\mathrm{O}$ importante é que a gente faça alguma coisa. E quando a gente fica meio parado assim, a gente acha falta. Esse negócio parece que fica te cutucando: "Você tem que fazer alguma coisa, você está parado demais. O que está acontecendo?". Então, a vida da gente é essa. 
Eu vou no salão, eu trabalho 1 hora, assim, aí eu peço licença para o cliente: "Dá licença, eu vou dar um pulinho no banheiro".

Eu subo lá e vou no meu pai: "E aí, pai, está tudo bem?".

"Tudo bom, filho. Tudo tranqüilo".

"Jóia? Beleza?".

"Beleza".

Aí, eu vou no salão, vou lá trabalhar 1 hora... "E aí, pai, tudo bem?”. "Ah, está tudo bem". Esses tempos atrás, ele estava com gripe, aí a gente fica preocupado.

Faz três anos que minha mãe faleceu. Só que quando a minha mãe faleceu - e eu era unha e carne com a minha mãe -, me deu uma sensação, assim, de missão cumprida. Eu chorei pra caramba, mas depois eu pensei bem e falei: "TUDO o que eu pude fazer por minha mãe, eu fiz". Eu não tenho um pingo de arrependimento de nada. Eu pude fazer tudo de bom e do melhor para a minha mãe. Então, eu tenho que ficar alegre. A minha mãe viveu com problema de pressão alta, diabete, 30 anos, mas comendo, não fazia regime, e eu pegava no pé dela. $\mathrm{E}$ minha mãe gostava de vinho pra caramba. Eu pegava no pé dela: "Mãe, você não pode tomar". Às vezes, na salada dela, fazia e temperava com vinho. (risos) Ao invés de colocar vinagre, colocava vinho. O maior barato a minha mãe. Era o maior barato. (risos) A gente se dava muito bem.

Eu sei que valeu a pena tudo o que aconteceu. E essa relembrada aqui, que você... automaticamente vai conversando e vai renovando, vai relembrando um monte de coisas da vida da gente. Isso é muito bom. Muito bom que a gente recorda muitas coisas boas que aconteceram na vida da gente. Muitas coisas boas que passaram na vida da gente, acabo recordando. Eu sei que valeu a pena tudo o que aconteceu. Se tivesse que passar por tudo de novo, passaria. Mas eu não posso parar de participar. Tenho que continuar participando. Tenho que continuar participando. Tenho que continuar firme porque senão o barraco cai.

Essas experiências podem despertar outra pessoa. Podem reforçar a mente dela para que ela possa progredir mais na vida. Possa ter mais trabalho. Às vezes, a pessoa quer progredir, quer fazer alguma coisa, mas quer ficar de braços cruzados. Tem que ir para a luta. Tem que trabalhar. Seja na Igreja ou no trabalho do dia-a-dia, você tem que encarar. E o certo seria trabalhar em obra social, estar trabalhando, ter um salário para sobreviver também, que todo mundo tem que sobreviver. Mas eu não tive essa chance. Então, acho que a gente tem que continuar caminhando, né.

Rapaz, é tão gratificante a vida da gente, assim, a passagem que você teve! Quantas pessoas.

A mulher: "Seu João, eu nunca esqueço na minha vida o que aconteceu".

Eu falei: "O quê?".

"Você. Você foi um anjo na nossa vida".

"Por quê?"

"Você não lembra, João? Que você nos mandava pegar leite todo dia de manhã no mercado. Depois você ia lá e pagava. Eu tinha seis, sete filhos para criar, tudo pequeno, sem um pingo de situação. Aquele leite e os pãezinhos que você mandava eu pegar lá, João, cuidou dos meus filhos muito tempo".

"Ah, não estou nem lembrado disso... Mas eu fazia isso mesmo?".

"Você esqueceu?!?".

"Vixe. Mas o que a gente faz, a gente não fica lembrando". Parece que tira da cabeça, passou a época.

E nem sabia que tinha ajudado a mulher, rapaz. E os filhos dela hoje são tudo casados. Aí, passa uns tempos, daí uns seis, sete meses, a mulher: "Ei, João, você foi um santo na 
nossa vida". "Mas santo por que?". "Você lembra que você ajudava?". Ela só falou há uns tempos atrás aí que eu ajudei. Não, mas isso... eu não fiz nada... isso aí é minha obrigação... não foi nada. Não foi nada. O que eu fiz naquela época, hoje se você está podendo fazer por outros... "Ah, João, sempre que eu posso eu ajudo mesmo as outras pessoas. Estou ajudando muito. Porque você foi tudo de bom para nós. Meus filhos estão tudo criados, não tinha nada para comer, nem para beber". Você vê rapaz, que coisa gratificante, que você nem lembrava que fez. Nem lembrava.

Aí, outra vez, vem outra lá: "Ah, João, mas como eu sou feliz por você ter me convidado para participar do Grupo de Rua, das CEBs".

Falei: "Mas por quê?".

"Você vê minha participação na igreja hoje é tudo por causa daquilo lá. Eu não ia na igreja, não ia em nada. E quando você foi na minha casa visitar, pediu para ir e eu aceitei, e você colocando, os outros colocando lá também, eu senti que eu tinha compromisso também".

E hoje ela é animadora de grupo. Faz mais de 15 anos que ela é animadora de grupo. E me agradece até hoje. Mas eu falei: "Mas o que é isso? Você se esquece...". Então, são coisas gratificantes. São coisas que a pessoa fala para você, que você nem esperava.

Outro dia, aqui embaixo, eu parei, aqui perto do hospital, parei num barzinho lá. Ia me encontrar com a namorada. O cara falou: "Você é daqui da Igreja São Geraldo, né?".

Eu falei: "Eu sou".

"Ah, quantas vezes que eu vejo você lá. Eu conheço você de lá", o dono do bar. "E você também cortou meu cabelo quando eu era pequenininho. Não lembra?".

Eu falei: "Puta merda. Filho de quem você é?".

Aí, ele falou que o pai ainda lembrava. Então, são coisas assim, que você faz, e talvez você não se lembra da pessoa, mas a pessoa lembra de você. Então é bom, onde você passa...

Na minha história de vida tudo o que me fortaleceu nessa caminhada foi Jesus e Nossa Senhora, que é minha protetora. E, em segundo lugar, os meus pais. Estou sentindo que tudo o que eu fiz valeu a pena. E estou feliz por isso. Se eu tivesse que passar por tudo isso de novo, eu passaria. E espero que Jesus me dê muita força para que eu continue com esse trabalho bonito na Igreja. 


\subsection{Margarida}

Eu nasci em Alagoas, mas eu vim pequena de lá. Era pequena, não. Eu vim com uns 12 anos... uma coisa assim. A gente era em 13 irmãos. Eu sou já das do fundo.

A cidade onde eu nasci se chama Água Branca, em Alagoas. E era muito gostoso lá, sabe. Me criei num lugar muito gostoso. Meu pai e minha mãe eram muito católicos. Muito mesmo. E eles tinham amizade com amigos que trocavam nas festas de Ano Novo, de Natal, festas juninas - que é festa de São Pedro, São Paulo, essas coisas. Fazia na casa de um e outra vez fazia na casa do outro. Então, era muito gostoso naquela época.

De quando eu era bem pequenininha eu não vou dizer nada porque era pequenininha. Eu vou dizer de quando eu me entendi por gente, que foi essa época assim, que era muito gostoso. Meu pai era muito bom pra ir com a gente para as festas. Ele gostava muito de reisado nessa época de Natal. Eles faziam cada reisado lindo em casa. Ele mandava chamar o reisado para cantar em casa. Então, a gente tinha uma vida muito boa com ele, muito divertida.

Agora, a missa era longe. A gente andava pelo menos uma base de 8 quilômetros ou 10, por aí. A gente ia de manhã para a missa. Não deixava de ir. Era lá em Água Branca mesmo. Aí a gente ia. E, então, depois meu pai resolveu vir pra cá.

Lá, meu pai era lavrador. A gente trabalhava de roça. Eu trabalhei muito de roça. A gente plantava mandioca. Porque lá no Norte a mandioca era de fazer farinha. Tinha a fábrica. Depois, pegava, arrancava a mandioca, levava lá na fábrica. Tinha as pessoas que descascavam a mandioca. Tinha as pessoas que ralavam a mandioca. Tinha as pessoas que ficavam na roda, que era de rodar pra poder sair a massa. Daquela farinha vinha a tapioca, da tapioca se fazia beijus. Aqueles beijus gostosos. E era uma vida assim...

Com todo mundo lá era assim. Lá se trocava o dia para uns fazerem numa semana e, depois, outros fazerem noutra semana. Então, aquela casa de farinha era do meu pai. Mas só que ele distribuía a todo mundo. Todo mundo tinha direito. E era assim.

E depois disso é roça. Que a gente plantava tudo. Plantava milho, plantava feijão. Então, todas aquelas coisas. Minha vida naquela época foi assim.

Aqui eu também trabalhei na roça. Minha vida foi trabalhar na roça, enxada, tudo. Eu peguei tudo, eu sou da roça mesmo. Eu choro de saudade porque não tem como...

Depois, meu pai resolveu que não queria mais ficar lá. Aí, veio embora. Veio com tudo. Os casados, as solteiras, vieram tudo pra cá. Fomos para Guararapes. Aí, ele foi tocar roça. Plantava algodão, arroz, milho, amendoim. E a gente ajudava.

Em Guararapes a terra não era nossa. Era terra arrendada. Aí, tinha o que o povo lá chamava 'capanga'. Mas não era capanga, não. É gente que podia, que tinha muita terra. Eles pegavam e alugavam para as famílias que tinham muitos filhos - assim como meu pai tinha. Eram muitos alqueires. Aí, a gente ensacava tudo. Depois, quando colhia todos aqueles mantimentos... era amendoim, era arroz, era algodão, era tudo quanto fosse de mantimento que era para desfrute, para alimentação do povo, a gente fazia. Aí, depois, ele guardava, depois vendia, e a renda dava para o dono lá. Tinha a renda dele.

Depois, o meu pai achou que não queria mais ficar em Guararapes. O que ele fez? Ele foi para Mato Grosso. No Mato Grosso, o governo estava dando 16 alqueires para cada família, caso de uma família grande assim como a do meu pai. Aí, cada um ganhou 16 alqueires. Mas ganhou mesmo, sabe. O governo passou as terras para cada pai de família, ficaram sendo da gente mesmo. Lá ele ficou no Mato Grosso, o tempo todo. Todos trabalhando. Cada roça muito bonita! Porque todos eram trabalhadores. E aquelas roças lindas. Aquelas roças de algodão, aquelas roças de arroz, era coisa muito bonita. Só que para Mato Grosso eu não fui, não. 
A minha tia morava aqui e gostava muito de mim. Aí, ela pegou e falou para meu pai: "Eu vou levar a Margarida pra São Paulo". Ele falou assim: "Pode levar". Aí, eu vim para cá.

Eu fui morar com a minha tia. Só que eu ia sempre lá. Às vezes, eu ia de avião, outras vezes ia de... eu já fui até de trem - Maria Fumaça - pra lá. E sempre visitava ele. Onde fui morar era em São Paulo, na Capital. Eu fiquei lá mesmo. Aí, aconteceu que eu gostei do meu marido, a gente se casou e tudo.

Ele trabalhou em loja, mas quando nós casamos, fomos para a Bahia, numa cidade chamada Candiba. Ficamos 3 anos e meio lá. Ele trabalhava na feira. Ele vinha comprar roupa aqui e levava para a gente trabalhar na feira. Era muito gostoso também. Eu rodei o mundo inteiro, sabe. Foi muito gostoso!

Até que, depois, com 1 ano, eu tive meu primeiro filho. Lá eu fiquei grávida do meu primeiro filho e ganhei ele. Em 3 anos e meio vim embora para cá mais meu marido de novo. Aí, foi começando a vida assim. Ele trabalhava em loja, depois ele quis trabalhar em comércio aqui em Santo André.

Aí, quando ele começou no comércio foi que começou, assim, que ele não tinha tempo. Ele não tinha mais tempo de vir ver a gente, porque o comércio é uma coisa que ocupa muito. Então, foi aquela época que eu comecei... já tinha meus dois filhos, eu trouxe também a avó deles pra cá. A avó deles era uma pessoa muito doente. Ela tinha bronquite e ficava muito ruim. Ficava, às vezes, até 1 mês internada. E eu cuidando dela.

Aí, foi na época que comecei a me sentir mal porque não via mais meu marido. Então, eu queria ter palestra e, às vezes, não tinha, né. Ele chegava cansado, e também gostava muito de brincar por fora, com os amigos, e aconteceu, né. Agora, foi na época que aconteceu que eu precisei me tratar com um psiquiatra. Então, fui me tratar com esse psiquiatra, mas não dava certo.

Eu não frequentava muito a igreja, não. E eu fiquei sentindo que precisava de uma coisa, eu precisava de uma coisa boa para eu poder criar meus filhos. Foi o tempo que veio o César $^{*}$ - o César é especial, né -, e eu sentia como quem estava meio perdida... Eu era uma boa mãe, cuidava, mas eu passei por muita angústia, nervoso, tudo. Foi quando eu comecei a me tratar com esse psiquiatra em Vergueiro. Mas comecei a me sentir mal, porque o remédio não me servia, só me deixava pior, me deixava doente, eu tinha sono. Pensava: "Como vou cuidar dos meus filhos direito?".

Um dia, eu lembrei que tinha que voltar nesse psiquiatra, mas não para tomar remédio. Eu queria conversar. Aí, eu fui. Cheguei lá, eu falei para ele que naquele dia eu não queria remédio, eu queria conversar. Eu precisava me desabafar, estava precisando conversar para fazer um desabafo, que eu vivia muito sem diálogo e eu não podia viver sem diálogo. E eu tinha meus filhos, precisava saber criar meus filhos. Aí, ele me deu essa pessoa, que é uma psicóloga.

Ela foi uma pessoa muito importante para mim. Importante por quê? Ela foi uma luz. Eu senti que ela foi uma luz. Depois que eu conversei com ela, que eu vim embora, eu imaginei que foi uma luz do Divino Espírito Santo que veio conversar comigo. Por quê? Ela conversou comigo, mandou contar meus causos, e eu contei. Quando eu falei que eu tinha uma criança especial, ela falou assim: "Chega, já chega. A senhora não vai mais no psiquiatra. E quero perguntar se é católica ou se segue qualquer religião. Pode ser qualquer religião, não tem importância, mas que a senhora siga". Eu falei para ela que eu era católica, mas que não estava seguindo direito. Aí, ela falou assim: "Nossa, a senhora tem que seguir. Vá, procure sua Igreja, siga uma comunidade da Igreja. Procure muito seus amigos e pense. E esse

\footnotetext{
* As pessoas citadas e marcadas com este sinal correspondem a seus nomes reais. A marcação de nomes reais só acontecerá na primeira vez que o nome for citado nesta narrativa. Todos os demais, sem esta marcação, tiveram seus nomes substituídos por outro, fictício. A decisão sobre a manutenção de alguns nomes reais entre os nomes fictícios foi tomada junto com a narradora.
} 
remédio do psiquiatra, jogue no lixo porque não está lhe servindo, está lhe fazendo mal. O seu problema é espiritual, não é material, não. A senhora não está só sentindo dor. A senhora está sentindo falta da parte católica. Da parte de Jesus Cristo a senhora está sentindo falta. Vai lá curtir, neste momento que a senhora está precisando criar seus filhos, saber como cuidar deles".

Aí, eu peguei e vim embora. E eu não fui mais no psiquiatra, não. Aí, sabe o que aconteceu? Naquela semana já estava começando o trabalho das CEBs. E quem fez a primeira celebração das CEBs nos lugares foi o Perseu. Daí, eu fui na Igreja São Geraldo e me juntei com o Perseu em respeito da comunidade, para nós dois começarmos a celebração. Aí foi que tudo começou.

Até a gente estava fazendo um grupo aqui em cima, o grupo do Guaraciaba. E tinha, na frente, um monte de pedrinhas. E nós fizemos a celebração em cima dum monte de pedras, nós não fizemos em casa nenhuma. Aí, o Perseu falou assim: "A senhora é ótima, vai ficar comigo para fazer esta celebração". E depois eu fiquei pensando. Eu fiquei fazendo celebração com ele, mas eu não assumia. Eu só assumia vir, mas assumir eu mesma, de pegar um grupo, não. Eu pensava assim: "Eu não sei ler muito bem".

Naquela época, o Cesinha era pequeno. O outro também já estava nos estudos. Meu marido continuava a ser comerciante. E eu comecei a seguir. E com esse espaço que eu comecei - esse espaço bendito - foi que aconteceu muita coisa boa comigo. Muita, muita, muita.

Aí, eu queria ajudar os pobres - que eu era pobre também, mas queria ajudar os pobres. Eu saía pelo mundo, atrás, com uma sacola, pedindo as coisas pros pobrezinhos. Tinha vezes que eu juntava tanto que não dava, vinha trazer pra casa e depois eu ia buscar de novo, de tanto mantimento que eu recebia.

Eu tinha um irmão por nome de Dalvo que também era das CEBs. Aí, se juntaram o Dalvo, e tinha outro, o Silvio. Juntaram Dalvo e Silvio comigo para ir trabalhar. Depois, teve a Capela Caridade. Naquela época, o padre José Mahon* já tinha chegado há pouco tempo. Aí, ele pegou e começou. Comprou esse terreno, mas esse terreno era no alto, aqui. Nós é que tomávamos conta: o Quincas, o Silvio, o Dalvo e eu. A gente fazia quermessezinha para ajudar e ver se construía uma capelinha, aquelas coisas. Aí, já era um trabalho que nós começamos nas CEBs. E fora a celebração, que era com o Perseu. Quando o padre José chegou, já tinha esse trabalho lá da Caridade.

Aqui não tinha luz e nem asfalto. A região aqui era mais taboa. Conhece taboa? A taboa é assim: ela cresce e depois ela solta uns pendões. Tinha até gente que pegava os pendões e mandava pintar para colocar em vaso dentro de casa. Então, isso aqui era taboa e capim. E também tinha grotinhas, era tudo assim, sabe, minando água. Em todo lugar que você punha terreno, minava água. Não tinha casa nenhuma por aqui. Lá na Valentim Magalhães, que foi onde eu fiquei também, não tinha. Tinha um tancão lá pra cima que só morria gente todos os dias. Chegava nas férias, principalmente, as crianças iam nadar e morriam. Aí, os bombeiros vinham tirar de lá de dentro. Era um sofrimento, sabe. E foi aqui que nós viemos, vindos de São Paulo. Meu marido achou para nós morarmos aqui.

Quando nós viemos da capital para cá, eu não tinha conhecido nenhum. Depois é que eu fui conhecendo. Hoje, graças a Deus, eu tenho muito conhecimento, muitos amigos, amigos mesmo. E isso foi dependendo da fé. Eu andava, procurava as casas, procurava para fazer as rezas. Aí, fui descobrindo gente, os amigos, e aconteceu que estourou minha amizade.

Quando chegou aqui, meu marido comprou um barzinho, veio trabalhar com comércio. Lá, ele trabalhava com loja. Aí, ele chegou aqui foi e tomar conta de comércio. 
Aí, o padre José veio e fez uma comunidade muito bonita. Depois que ele fez aquela comunidade, ele começou a juntar o povo para fazer abaixo-assinado pra ter a luz e ter o asfalto.

Quando eu levava o Cesinha na Casa da Esperança, eu levava uma faquinha de mesa dentro da bolsa para quando chegar na Casa da Esperança eu tirar o barro do sapato, porque ficava dessa altura de barro. Lá na porta eu tirava o barro, depois passava um paninho, aí eu entrava na Casa da Esperança. Quando chovia, o sapato ficava alto de barro. E era um sofrimento medonho. Mas naquela época lá eu também não imaginei que era sofrimento. Para mim estava sendo muito bom, sabe.

Uma coisa que aconteceu também é que na véspera do atentado do papa eu saí da minha casa pra ir à igreja. Aí, eu subi essa Rua Antonio Correia. Na volta tem uma ladeira. Quando eu subi aquela ladeira, estava tão escuro, aí vinha uma luz assim... vinha aquela luz e eu atravessei. Quando eu fui atravessando, era um carro e o carro me pegou. Eu tive um acidente. Não cheguei nem a ir na reunião que eu ia, com o padre José, com o Perseu, das CEBs. Aí, eu fiquei 3 meses me tratando. Quando eu voltei na igreja, o padre José me pôs no altar para falar como foi, porque falei para o padre José que eu estava contente porque eu tinha sido acidentada na véspera do atentado do papa. Então, o papa estava sofrendo e eu estava sofrendo junto com ele. Aí, se passaram todas essas coisas.

Uma vez, chegou de Minas Gerais um povo. Quando nós chegamos na igreja, na frente estavam todos no chão, deitados em cima daquela esteira. Então, a Igreja São Geraldo ficou com pena e deixou aquela família ficar lá na igreja. O padre deu esteira tudo lá pra eles, e eles forravam lá e deitavam. Eu tinha uma outra amiga que fazia o trabalho comigo e o Perseu. Ela se chama dona Cila, e mora aqui perto em cima. Ela também trabalhou comigo e fez muita coisa boa mais eu. E eu, com essa dona Cila, fomos aí na favela e depois fomos na assistente social para pedir um pedacinho de chão para a gente. Eles deram um pedacinho de chão e aí nós arrumamos as tábuas, materiais, e fizemos um barraco de quatro cômodos nesse tempo. Aí, esse povo mudou para lá e ficou. Eles estavam muito felizes. Quando ela teve uma criança, deu para eu e o Dalvo batizarmos, de tanto que ela ficou grata com a gente. Batizamos esse filho dela.

Teve tanta coisa bonita, Gustavo, que eu não sei nem te dizer como foi. Inclusive, até hoje está sendo bonito. Porque a gente fez um trabalho bonito pro povo. E hoje eu já estou de idade e não tenho mais aquela força de fazer essas coisas, mas graças a Deus eu já fiz, né. Além disso, eu fiz outras coisas, assim, de amizade. Descobri muita gente que hoje em dia já é Grupo também.

Os primeiros que participavam das CEBs eram a dona Cila, o Dino - que agora mora lá na represa -, o Perseu... E tinha pouca gente, sabe. Todo esse povo de hoje já foi gente que foi descobrindo... que foi trabalhando nas CEBs depois. Esse grupo velho era pouco: era eu, dona Cila, Dino, Perseu. A gente foi fazendo retiro grande. E assim foi descobrindo muita gente, porque quem ia nos retiros e gostava, aí foram se dedicando também.

Ah, uma coisa muito interessante foi que as CEBs foi um trabalho muito bonito que fez muita gente ser católico. Gente que nem era católico e ficou católico. Fez gente acreditar em Deus, né. Eu, pelo menos, depois desse trabalho pra cá, desse psiquiatra, eu atuo no trabalho de igreja. E fui vendo que a gente não pode viver mesmo sem Jesus Cristo, a gente não pode viver mesmo sem ter os amigos. Mas os amigos bons, da igreja, que participam com a gente, que é para poder fazer a gente feliz e a gente fazer eles felizes também.

Aí, nessa época, Gustavo, eu fui me movimentar melhor na igreja e ter mais felicidade. Soube criar meus filhos melhor, e neto. E meu marido continuou sempre sendo comerciante. Mas eu sempre dizia para Jesus Cristo que um dia eu queria ele junto comigo, na igreja também. Porque quando acontecia de ele assistir uma missa lá, uma vez ou outra, quando 
acontecia, ele não tinha muita fé, não. Ele ia lá porque ia mesmo, mas não tinha muita fé, não. E eu sempre caminhava pedindo a Deus que colocasse minha família nesse caminho comigo. De repente, foi passando o tempo e quando ele vendeu o bar, começou a ir para a igreja comigo. Aí, ele ficava no banco, assim, mas sério, e eu cantando no Coral. Chegava em casa, eu falava: "Bem, fica lá comigo, vamos lá para você não ficar sozinho junto com o povo. Lá você fica junto com a gente, no Coral".

E ele: "Ah, eu tenho vergonha".

"É, não tenha vergonha, não".

Aí, um dia teve uma missa sertaneja e eu falei para ele: "Vamos assistir a missa sertaneja comigo lá no Coral, Bem. Ah, é muito bonito, muito gostoso cantar". E ele sentou no banco e cantou. Aí, o coordenadorzinho nosso, que se chama Sálvio, falou assim: "Seja bem-vindo, seu Sebastião*. Não saia mais do Coral, fique com a dona Margarida”. Aí ele foi ficando, não saiu mais. Aí ele adorou. Adorava cantar, adorava a missa. E ele ficou na igreja junto comigo. Depois, eu pedi para ele fazer as celebrações nas casas, das CEBs, comigo. E ele começou a fazer a celebração nas casas comigo. Depois, ele foi e assumiu o Terço dos Homens na igreja. Assumiu aquele trabalho muito bonito.

E assim, Gustavo, foi as CEBs. E as CEBs continuam. Mesmo acabando as coisas mais fortes. Pois antigamente eram muito fortes as CEBs, porque tinha muita reunião, tinha muito retiro por fora com todas as igrejas. Um pouco disso daí parou, mas as CEBs não pararam, não. Eles colocaram agora nome de 'Grupo de Rua', mas o nome mesmo é 'CEBs': 'Comunidades Eclesiais de Base'. Então, 'Grupo de Rua' também é bom, né, que é na rua que a gente faz o trabalho.

E depois que eu fiquei mais de idade, eu já não estou mais aguentando muita coisa, sabe, fazer tudo aquilo que eu fiz. Mas só que tem uma coisa: a felicidade minha é tão grande porque na época que eu fui, na época que eu tive coragem, eu trabalhei. Trabalhei. Deus me deu muita força e até hoje está dando.

E foi quando eu comecei a dizer para Deus me perdoar de eu ter sido uma pessoa que não... Eu vim aqui para São Paulo, mas eu não segui a Igreja assim, sabe... não era que eu não... mas eu não seguia mais a Igreja. Sabe como era que eu fazia? Eu passava nas igrejas com meus dois filhos, aí eu entrava lá e: "Em nome do Pai, do Filho e do Espírito Santo", né. O trabalho mesmo eu não tinha. Era: "Não filho, vamos entrar aqui na igreja". Daí eu chegava lá, ajoelhava um pouquinho e: "Em nome do Pai, do Filho e do Espírito Santo", aí eu levantava, pegava meus filhos e vinha embora. Então, eu achava que já dava. Mas não dava. E o que eu faço hoje também não dá ainda. Mas estou fazendo. Estou com você aqui, estou muito feliz, nós vamos trabalhar, vamos continuar e estou disponível em tudo que você quiser. Porque sei que você é uma pessoa capaz e isso daí me dá muito prazer. Por quê? Você é uma pessoa que... numa tarde de domingo, ao invés de você estar na televisão, não é isso que você quer, você quer estar aqui mais eu, né, escutando essas palavras bonitas, achando que eu tenho que ficar com você, mesmo assim, sem saber ler direito.

Aí depois, Gustavo, foi que eu fui perceber que para a gente gostar de Deus não precisa saber ler, não. Sabe por quê? Porque quando eu comecei, quando eu saí de junto do Perseu, eu já saí porque ele me esparramou outras coisas. Ele mandou que eu assumisse o meu grupo porque eu já era capaz. Aí, eu assumi meu grupo. Foi quando eu comecei com a dona Hosana, com a Manoela... todo o povo que hoje é grupo, eles começaram comigo. Eles começaram comigo. João* Cabeleireiro, todos eles começaram comigo.

"Vamos fazer reunião numa casa?".

"Vamos".

"Aqui é Comunidade Eclesial de Base, é a CEBs. Vamos trabalhar, vamos esparramar". 
Aí, depois, a Igreja viu que as CEBs não precisava ficar só com aqueles grupos que nós começamos. A Igreja achou que era pouco aqueles grupos de quando nós começamos. Se eu tinha 30 pessoas no meu grupo, então, daquelas 30 pessoas, cada um tinha que assumir o seu grupo para poder ficar bastante. Foi assim que aconteceu. As pessoas: "Agora não vou mais andar com a Dona Margarida, agora vou assumir meu grupo". E o outro também: "Agora vou assumir o meu grupo". E assim foi. Então, eu estou aqui, satisfeita, contente. E foi assim, Gustavo. Muito importante.

Eu fui doméstica. Eu nunca fui operária. Eu só fui doméstica e adorava trabalhar como doméstica. Até hoje, se eu pudesse, eu ia trabalhar como doméstica. Nessa época, eu morava na Capital.

Eu só morei aqui em Santo André depois do casamento, depois que já tinha o Sérgio*, o mais velho. Aí, eu vim aqui para Santo André, fiquei grávida do César.

Eu trabalhei em diversas casas. Mas eu trabalhei muito numa casa que eu fiquei muito tempo. Foram 10 anos numa casa onde eu gostava muito da mulher, da família, e eles gostavam de mim. Naquela época, trabalhar em casa de família não era como hoje. Hoje quem trabalha em casa de família é registrada, exige, né. Naquela época, a gente não exigia nada, era um trabalho assim... sei lá, acho que só para poder viver. Mas hoje é diferente. Mesmo assim eu gostava muito de trabalhar em casa de família. Nunca procurei trabalhar em fábrica nem em loja. Nunca. Eu só trabalhava em casa de família, porque eu gostava demais.

Eu gostava porque, pra começar, eu gostava muito de dormir nas casas delas. Porque minha tia morava na Penha. Depois da Penha, ela se mudou para a Ponte Rasa. E era longe. Então, eu vinha para ficar com minha tia mais no fim de semana. Depois de muito tempo é que comecei a morar mais ela. Mas eu gostava muito de dormir no serviço. Ali, já amanhecia o dia no serviço... Isso se eu gostasse da patroa. Agora, quando eu não gostava, eu também não ficava nem um dia. Se eu arrumasse uma casa em que a patroa não fosse simpática ou se ela fosse essas pessoas que pudessem maltratar... Que eu nunca gostei de maltrato. Nem eu maltrato os outros, nem gosto que ninguém me maltrate também. Então, eu já saía. Mas geralmente eu ficava muito nas casas. Ficava 3 anos, 2 anos numa casa. Eu já trabalhei mais de 10 anos numa casa.

Quando alguém maltratava, era maltrato assim: vamos supor, sabe quando a gente vai trabalhar num local que a gente não conhece - pode ser em qualquer lugar, pode ser fábrica, pode ser o que for - a gente já vai lá nos primeiros dias meio sem ter prática, né? Então, até aí tudo bem, tem que ensinar, tem que dizer: "É assim que eu gosto". Mas depois, ser exigente como que fosse... Porque mesmo sendo pobre... não é obrigada a ser rica, mas tem gente que gosta de ser muito herói, né, gosta muito de mandar, gosta muito de querer ser mais, e tudo. E aí, o meu problema é assim, sabe: todos nós somos iguais, não somos? Então, eu acho que em todo lugar tem que ter respeito também, não tem? Então, acho que não era por ser minha patroa que ela poderia ficar em cima, ou passando o dedo nas coisas para ver se eu limpei mesmo. Aí já não era comigo. Do jeito que eu faço na minha casa - gosto da minha casa limpinha -, também eu gostava da casa dos outros bem limpinha. E sempre quando eu trabalhei em casa de família, eu fui uma pessoa que trabalhou muito bem.

Eu fiz de tudo em casa de família. Já cheguei a ser de tudo. Já cheguei a ser passadeira de roupa, faxineira, tudo. Então, aprendi muito com isso. Cozinhar. Aprendi muito a cozinhar também e, então, eu achava que a patroa também tinha que colaborar com a gente, né.

Mas, também, foram poucas casas que eu achei que tive que sair por isso daí. Mas, geralmente, nas casas que eu fiquei, trabalhei bastante tempo, muitos anos. E quando eu casei, eu trabalhava em casa de família. Então, eu acho que a gente tem que dar valor na gente mesmo também, né. 
Se eu não der valor para mim também... Assim como eu respeito, também tenho que ter respeito. Tenho que ter respeito para eu poder também dar respeito para os outros. Então, trabalhei muito em casa de família.

Depois que casei, nós fomos para a Bahia, eu e meu marido. Os pais do meu marido moravam tudo lá em Candiba. Eles são de lá. E nós fomos embora para a Bahia. Ficamos 3 anos e meio. E eu gostava da Bahia pra caramba, sabe, eu gostava muito. Eu ia a uma igreja que eu adorava. Gostava MUITO, MUITO, MUITO daquela igreja. Quando eu saí, eu chorei tanto por causa daquela igreja, sabe. E eu vim ter o meu filho aqui, o Sérgio - o mais velho. Eu vim ter ele aqui, mas para depois voltar. Então, depois, ele veio me buscar. Ele veio, pegou eu e a criança e levou de novo para a Bahia. Aí, chegamos lá, ele colocou serviço para trabalhar em feira. Ele vinha aqui fazer compra de roupa de mulher - era mais peça de mulher. Ele vinha buscar roupa aqui, chegava lá e eu ia trabalhar na feira mais ele. Aí, meu filho Sérgio já tinha nascido há pouco tempo. E a gente tinha aquela vida tão gostosa lá na Bahia, sabe. Era muito gostosa. Um lugar pequenininho, e eu tinha bastante amizade lá com algumas pessoas, que, inclusive, essas pessoas hoje moram aqui também, vieram embora pra cá.

Mas eu já mexi com muita coisa na vida. Já trabalhei na roça, já trabalhei de doméstica. De serviço foi mais isso mesmo: doméstica e roça. A roça eu adorava! Eu pegava numa enxada assim e parecia que eu era um homem. Eu trabalhava, e arrastava a enxada na roça, eu cavava, eu puxava, eu cavava buraquinho pra plantar milho, plantar todas as coisas, amendoim! Eu ajudava meu pai em tudo. Nós éramos muita gente. Meu pai botava a gente para ajudar na roça e a gente ia mesmo, de gosto! Então, é a mesma coisa como doméstica. Eu achava que eu era doméstica e acabou. Nunca procurei loja, nunca procurei firma. Para mim aquilo ali já era o suficiente.

E eu trabalhei numa casa, mais de 3 anos, e a mulher era espírita. Era espírita. Mas ela era MUITO boa comigo. Até hoje eu tenho saudade dela. Tenho vontade... se eu pudesse ver ela, as crianças... Aí, ela tinha muita confiança na gente, sabe. Então, ela ia trabalhar e deixava as crianças comigo. Eram duas crianças que ela tinha. Aí, eu me lembro que eu terminava o serviço, eu pegava as crianças e ia lá para a casa da avó das crianças para passear. Quando foi um dia, eu peguei as crianças e nós fomos lá para a casa da avó. E tinha outra coleguinha minha que trabalhava junto, vizinha comigo, que era da mesma família. A gente se juntava e ia tudo junto. Ela levava parte das crianças dela e eu levava parte da outra família era a mesma família, mas era em duas famílias, ela trabalhava numa casa e eu trabalhava na outra. Aí, a gente ia tudo para a casa da avó.

Chegava lá, a gente fazia aquela farra com as crianças. Aí, depois, veio aquele temporal de chuva. E eu falei: "Vamos correr! Vamos embora, que vai chover e depois que chover não vai mais dar para a gente chegar em casa, e eu tenho que fazer janta, que meus patrões vão chegar!"

Aí, a avó falou assim: "Ah, mas espera um pouco. Não vai mais dar tempo, não".

Eu falei assim: "Não, mas vai dar tempo". Aí, eu peguei o menor - ele já corria, já era sabido - no braço, e o outro veio atrás de mim, e nós tudo bobos, correndo e gritando debaixo da chuva. Aí, nesse meio tempo começou a chover antes de a gente chegar. "Eita, mas começou a chover". Aí, eu voltei para pegar o outro - que eu já estava pegada na mão de um -, e quando eu fui voltar para pegar na mão do outro, aí ele encontrou comigo de uma tal maneira que bateu com a cabeça bem forte mesmo, nessa parte do nariz. Fez PÁ, PEI!, assim, que quase eu caio. Aí, começou a sair sangue. Tudo isso aconteceu. E nem por isso, né. Ai, mas eu fiquei tonta e assim sem saber o que fazer, porque a chuva começou. Mesmo assim saí com as crianças, chegamos em casa, e fui gargolejar água assim no nariz para tirar aquele sangue todo. 
Quando foi de noite, ela chegou e falou: "Eu vou levar você no médico". Aí, me levou e estava boa. Eles me levaram. Eu tinha machucado essa parte do nariz, esse ossinho aqui. Até hoje é machucado. Esse aqui ó, eu faço assim e até hoje ainda dói.

Então, aconteciam todas essas coisas comigo porque eu assumia pra valer, sabe. Assumia minhas obrigações: obrigação com as crianças, obrigação com o serviço. Eu tinha responsabilidade de cuidar para que, quando chegassem, tinha que ter a jantinha pronta, tudo.

Era muito gostoso, Gustavo, naquela época lá. Hoje é gostoso porque eu tenho a minha casa, né. Tenho minha casa, a casa é minha, mas eu gostava muito. Então, eu era muito comunicativa, eu tinha muito paladar na minha vida, sabe. Que tudo que eu fazia eram coisas que eu adorava.

Aí, quando chegava o fim de semana, eu ia pra onde estava minha tia. A minha tia era muito boa, uma pessoa muito bacana, muito legal. Ela morreu com 105 anos!

Então, tem a minha prima que mora na Parada Inglesa, que é a filha dela, e tem a outra que mora em São Miguel Paulista. Quando elas ligam para mim, elas dizem assim: "Oi, minha irmãzinha!". Então, a gente só se chama de irmã. Elas me chamam de irmã, e eu também chamo elas de irmã. Porque a gente viveu muito juntas. Era muito bom, muito gostoso, e eu tenho muita saudade. Até hoje, para mim, eu estou fazendo ainda essas coisas, sabe.

E tive muito paladar na vida. De fazer as coisas que eu gostava. Eu gostava muito de ficar na casa da família pelo motivo de eu chegar de noite e ter mais sossego. Eu fazia o serviço e depois gostava muito de ficar na sala escutando televisão. E elas nunca me empataram. Então, tinha liberdade como se estivesse na minha casa. Aí, quando era no outro dia, eu gostava de levantar cedo para trabalhar, fazer o serviço direitinho como eles gostavam, e como eu gostava também. Então, a vida foi essa.

Sabe como foi que eu conheci meu marido, Gustavo? Na Vila Medeiros, tinha uma família que possuía muita propriedade. Então, eles tinham um salão, e eles pegaram e combinaram, com todos os moradores dali e as famílias, para fazer um salão de festa, de baile, para abrir e ter com que brincar. Aí, todo mundo concordou e ele falou: "Eu vou procurar isso daí porque eu quero fazer um salão social, em sociedade, não quero um salão que vem uma turma daqui, vem outra d'acolá, pois é gente que, às vezes, chega até sem respeito. Eu quero só sociedade, uma sociedade que seja só familiar, onde eu habito, que é o lugar de Vila Medeiros, Vila Gustavo, esses lugares assim”. É só por ali.

Então, o povo todo assumiu. Quando eu conheci, já estavam brincando lá no salão. Eu ia dançar lá. Gostava muito de dançar. Ia mais a madrinha do Cesinha, mais a filha dela.

Então, foi lá que eu conheci meu marido. Chamava 'Santa Luzia' o salão. Mas era tão gostoso, que tinha matinê à tarde, em dia de domingo. Então, a gente ia. E foi lá que eu conheci meu marido, assim dançando. Aí, começou de brincadeira, sabe, igual amizade, mas depois terminou sério. Eu fiquei muito tempo namorando com ele para a gente se casar. Fiquei mais de 3 anos namorando. Depois foi que a gente se casou. Está vendo como as coisas são engraçadas, né?

Naquela época, ele trabalhava... o Sebastião nunca gostou de fábrica, então ele trabalhava em loja. Lojas grandes. Trabalhou nas Lojas Garbo, em São Bernardo do Campo. Era vendedor. Por isso, quando nós fomos para a Bahia, ele fez uma venda ali na feira em que a gente vendia. Era por causa disso, ele tinha amor a esse trabalho.

Ele era baiano. Morava nesse lugar que nós fomos, que se chama Candiba. Aí, meu pai morava em Mato Grosso. E uma vez meu pai veio aqui, conheceu ele, e tudo. E ele não chegou nem a pedir em casamento, ele só falou assim: "Eu namoro com sua filha. Eu quero me casar". 
A gente se casou, parece que foi dia 4 de Maio. Nós casamos e já fomos para lá. Foi assim como se fosse uma lua-de-mel. Porque ele tinha a avó dele que ele gostava muito, e ela vivia na Bahia. Essa avó foi quem criou ele após os 6 anos de idade. E ele adorava ela. Aí, ele falou assim: "Nós vamos casar, Bem, mas nós vamos para a Bahia." Aí, nós fomos. Acabamos de casar, depois de uns 6 dias, por aí, nós já fomos para a Bahia.

Eu não conhecia lá onde ele morava. Ah, quando ele falou que ia, eu achei bom porque eu já estava cuidando dele. Então, tinha que ir para onde ele fosse. E aqui não tinha mais nada para eu fazer, que eu não ia mais trabalhar em casa de família também.

Fui pra Bahia e lá era um lugar muito pequeno, era uma vida muito mansa, muito boa. A gente não tinha muita coisa no que pensar. Só era a gente fazer o serviço, tudo, já ficava debaixo da viga. O povo gosta muito de ficar sentado nas portas, assim, nas cadeiras, naquele calorão. E ele gostava muito de brincar de dominó, essas coisas. Ele ia brincar de dominó com os amigos dele.

Depois ele cismou de pôr uma roça para ele. Porque o pai dele tinha muitos terrenos. Ele falou assim: "Eu vou trabalhar em roça". Aí, ele foi. Plantava feijão, plantava milho, tudo, e estava até gostando. Ainda fez uma casinha para a gente no fundo... Tinha a casa da avó dele e, no fundo da casa dela, ele fez uma casa de 3 cômodos e cozinha para nós. Uma casa bem bonitinha ele fez. Foi até aí que eu tive o Serginho.

E quando foi nesse ano que ele plantou esse mantimento, ele trabalhou MUITO, MUITO, MUITO, mas, de repente, quando a gente deu fé, o trabalho foi por água abaixo. Porque foi tanta chuva que ele perdeu as lavouras. Ele colheu feijão, colheu milho, colheu as coisas que ele plantou. Aí, foi na época que já estava seco, ele arrancou feijão, tudo. Aí, o feijão amontoado para secar, para depois bater, para tirar o feijão, ou o que fosse para vender, ou que fosse para não sei o quê. Aí, deu uma chuva, começou a chover como agora. Começou uma chuva tão forte, mas tão forte, que todo mundo perdeu os mantimentos que plantou. Aí, ele desgostou. Ele falou assim : "Ai, não dá, não... Não sei, não, mas acho que eu vou embora para São Paulo de novo".

Aí, eu não queria vir, não, porque eu gostava muito de lá e da igreja. Era uma igreja de gente assim muito... um povo muito popular, sabe. E, inclusive, tinha uma pessoa lá que eu me comunicava com ela, a gente fazia limpeza na igreja. E eu fazia reza de São Sebastião todo ano. Chegava o dia de São Sebastião, eu fazia a novena de São Sebastião. Ainda fazia aquela novena arrochada, gostosa, sabe. E ele também gostava de mexer com negócio de Semana Santa.

Aí, quando foi na Semana Santa, ele pegou e falou assim para o povo, e para os amigos: "Bora, vamos se reunir todo mundo que nós vamos fazer o Judas. Vamos fazer um Judas BEM GRANDE, BEM GRANDE, que é para a gente se divertir com esse Judas". Aí, juntou aquela homarada, e eles fizeram o Judas. Mas eles fizeram um Judas tão grande que a gente olhava assim e não tinha fim.

Depois ele falou assim: "Nós vamos fazer o Judas. E vamos fazer uma roda de foguete nas costas do Judas". E o Sebastião era muito cheio de sabedoria para essas coisas. Aí, ele pegou e fez uma roda assim. Depois ele pôs tudo aquelas vírgulas, sabe, assim, no meio. Ele fez um negócio que ela rodava. Quando ele mexia lá no negócio duma chave que eles fizeram - não sei como que foi -, então aquela roda rodava e foi ali onde eles enfiaram os foguetes para sair das costas do Judas. (risos) Eu não posso esquecer, viu. Aí, ele preparou todo o Judas mais os amigos e fez esse negócio aí e encheu de bomba. Encheu de bomba lá dentro e depois pôs tudo rojão do lado. Depois eles fizeram um assento, um negócio lá, um trono de sentar o Judas, que era pra na hora que eles tocassem fogo no Judas, aquela roda ia RODANDO, RODANDO, RODANDO, ia saindo BOMBA, BOMBA, BOMBA PEI PEI PEI PEI, FOGUETE, tudo, chega cobria o mundo! Eu não sei como é que eles conseguiram fazer aquilo. E tudo isso daí era a diversão daquela época. Que eles faziam. Aí, quando foi no dia 
da queima do Judas, que foi no Sábado de Aleluia, foi aquela festa tão grande! TODO MUNDO na cidade se juntou no local de frente à igreja para ver a queima do Judas. Mas tinha GENTE, GENTE. A cidade inteira fechou as portas e foi tudo para a praça. E para ele era gostoso porque foi invenção dele. "É assim que nós vamos fazer, e assim que vamos soltar. Nós vamos matar o Judas não é com porrada, é com o fogo nele". (risos) Aí fez aquilo.

Então, isso daí era diversão que hoje não tem. Mas só que hoje são coisas bonitas também, são coisas que a gente vai na igreja, assiste a missa. Lá não tinha muitas coisas de ir na igreja, que fosse uma Missa do Galo, essas coisas, não tinha. Não tinha padre na igreja naquela época. Então, quando a gente queria fazer uma festa na igreja, as pessoas da igreja mesmo eram que formavam a festa, que faziam as novenas, e tudo. Padre não tinha. Hoje tem, mas naquela época não tinha, não. Não tinha médico, não tinha nada naquela época. Então, o povo inventava essas manias para poder se divertir. Você vê que o Judas foi um barato, porque foi tanto foguete que queimou todinho o Judas. Nem a cabeça ficou, viu. (risos)

E era assim, sabe, Gustavo. Tudo, assim, diversão naquela época. Hoje é diferente. Hoje nem o Judas não tem mais.

A Igreja não era muito diferente, não. Era diferente só por não ter padre. Então, não tinha a missa de domingo. Quando era para batizar uma criança ou casamento, eles pegavam e iam a Guanambi - a outra cidade, que é perto... Eles iam a Guanambi dar os nomes. Em Guanambi se fazia toda a preparação do casamento. Mesmo que o casamento fosse em Candiba, o padre vinha a Candiba. Se fosse para batizar, era a mesma coisa. E o resto era o povo que fazia. Fazia as festas da Igreja. É muito gostoso. Fazia festa dia e noite, ficava até a meia-noite naquelas festas, fazia quermesse, tudo, era assim, sabe, era tudo o povo. Era tudo o povo de antigamente. Tinha o povão lá que fazia essas coisas.

Quem ficava com a chave da igreja era uma senhora bem negrona. Mas eu gostava demais dela. Acho que ainda é viva, viu. E eu me comunicava muito com ela. Então, eu me juntava com ela para nós fazermos as festas $\mathrm{E}$ as outras pessoas também, os outros amigos, que é família. Depois vinha a moçada, que gostava, querendo fazer quermesse. Fazia toda aquela quermesse na porta da igreja. Hoje, em todo lugar tem padre. Em todo lugar tem padre, em todo lugar tem seminarista. Mudaram muito as coisa da Igreja, né.

Naquela época a missa era em latim. Inclusive, no Norte, em Alagoas, ele fazia a missa com as costas viradas para o povo. Aí, quando era para dar a benção pro santuário, que era para o Santíssimo, ele pegava e fazia assim: Tirindindindindin... o sininho Tirindindindindin. Aí, ele ia virando, dava uma passadinha assim na franja para o povo ver, depois ele ia e virava, punha o santuário lá de novo com as costas viradas para o povo, e começava de novo a missa. Vinha a consagração da Comunhão, comungava, todo o mundo comungava, mas assim, ele com as costas viradas para o povo.

Eu acho que errado era naquele tempo. É porque... o sermão que eles faziam ninguém entendia nada, tudo em latim. Era tudo em latim aquelas palavras. Eu não entendia nada. Só quem entendia eram aquelas pessoas bem sabidas, que tinham o estudo daquela língua. Do contrário... E eu...

Aconteceu uma vez lá no Norte, Gustavo, lá na Água Branca, onde eu nasci, eles faziam a festa do dia 8 de dezembro. A festa do dia 8 de dezembro era muito linda lá. Faziam a novena, e eles não faziam dentro da igreja, não. Eles faziam ao ar livre, numa parte que era a feira, onde tinha a feira toda semana.

Toda semana tinha o dia da feira e era um quadro bem grande, era um terreno baldio bem graaaaannnnde, sabe, bem enorme mesmo. Ali era onde tinha feira, onde tinha festa. Quando tinha as festas de Igreja, vinha carrossel, tudo, e se formavam tudo ali naquela quadra lá. Era muito animado. E tinha lá uma família que era crente. 
Naquela época lá os evangélicos condenavam mesmo a religião nossa, sabe. Eles condenavam mesmo. Faziam até... Riam, diziam para a gente mesmo e para os padres que eles eram do Cão, todas essas coisas. E lá o povo tinha uma mania de os pobres darem os filhos para os ricos batizarem. E meu pai me deu esse homem para ser meu padrinho. Eles eram meus padrinhos e aceitavam. Aí, teve essa novena. Eles foram fazer um palanque bem grande, bonito, bem alto, onde o padre ia ficar, para eles poderem publicar a Palavra e o povo entender. Que aquela quadra lá ficava cheia de gente que vinha de longe. Vinha gente de longe na festa - que aqui é Nossa Senhora de Aparecida, mas lá era Nossa Senhora da Conceição, a padroeira da igreja. Então, eles faziam a novena de dezembro. Faziam 8 noites. Quando chegava a última, eles faziam aquela festa, e vinha gente de longe. Aí, estava todo mundo presente para o padre começar a novena. O padre começou a novena, depois chegou a época do sermão. Ele foi dar o sermão para o povo, aí veio aquele crente lá para matar o padre.

Ele veio para atirar no padre. Aí, ele chegou, veio de longe, e ele gritou para o padre que parasse de fazer o sermão que ele ia atirar nele. Aí, o padre abriu os braços, e falou assim: "Pode atirar".

Eu era pequena naquele dia, mas eu me lembro bem. Aí, ele abriu os braços e falou assim: "Eu estou uma cruz, eu estou virado uma cruz aqui na frente. Pode atirar". Aí, bateu no peito três vezes e disse: "Atire. Atire. Eu morro agora, contente, no meio do povo. Você pode atirar”. Aí, ele foi e atirou. Ele atirou: PEI! Atirou, mas não disparou nada. Ele bateu três vezes, assim, no gatilho do revólver: PEI, PEI, PEI! Mas não saiu nada de fogo, sabe. Aí, depois, o padre gritou, bateu no peito, gritou e disse assim: "Agora abra o seu revólver". Quando ele abriu o revólver, tinha uma fivela branca.

Uma fivela. Daquele jeito que ele fez aquela bala virar uma fivela no meio do povo, que é para o povo saber que a Palavra de Deus, também naquela época, como hoje mesmo, existia e obrava milagre.

Assim como hoje, as pessoas às vezes fazem pedido às imagens de Nossa Senhora Aparecida, vão na Aparecida do Norte, pedir, pagar promessa. Aqui na televisão, depois que teve a parabólica, eu assisto o programa do Pai Eterno. É muito bonito. O padre não é daqui, é de lá daquele lugar das fronteiras. Mas tem a imagem do Pai Eterno e é como que fosse uma imagem de Nossa Senhora do Rosário de Fátima. Ela é andeja, ele anda com ela. Então, aquele Pai Eterno tem Jesus, Maria no meio, e do lado o Pai Eterno, que é para ser Deus. De frente àquele quadro aí tem a novena de Nossa Senhora de Perpétuo Socorro, na parte da manhã. E o padre fala muito bonito. E a gente pega uma fé. Não na imagem, mas a gente pega uma fé, que está assistindo coisa de Deus. Que é Deus que existe e nós temos que ter alguma coisa nesse mundo para que a gente possa representar, na nossa mente, que Deus existe, que Deus está com a gente, e que a gente tem que não acreditar no padre, mas ter fé no que ele fala.

Então lá era desse jeito também. O padre falava uma coisa, e se ele falasse uma coisa ninguém nem... ele excomungava a pessoa. Falava: "Você não quer acreditar? Está zombando de mim? Então, você vai fazer isso e isso e isso e isso". Ninguém brincava, não.

Aí, ele pegou e falou para o crente: "Atire, que eu estou virado uma cruz". E bateu no peito e falou: "Essa cruz aqui, se você tiver medo dela...", mas eu tenho medo de uma cruz de ser humano. Aí, abriu os braços e falou: "E pode atirar". Ele atirou, mas não saiu fogo do revólver. Ele atirava assim, dava só aquele estralo, mas o revólver ficava parado. Depois ele foi e falou assim: "Não saiu nada, né? Então abra o revólver, mostre o revólver. E me traga o revólver aqui". Aí, ele pegou, abriu o revólver, mostrou, o padre foi quem tirou e falou assim: "Olha, aqui no revólver tem o quê? Não tem bala, tem uma fivela". Falou pro povo: "Tem uma fivela. Ele veio me matar, mas tem uma fivela dentro do revólver". Aí, depois, o padre pegou a cruz, o crucifixo de Jesus Cristo, e atirou bem no meio do povo. Atirou e falou assim: 
"Eu estou atirando esse crucifixo para esse pastor aí ir lá pegar. Se você quiser pegar a cruz, você vai pegar essa cruz. Se você não quiser pegar a cruz, eu vou descer e vou pegar a cruz". Aí, o crente não foi pegar a cruz. O padre pegou, desceu do palanque, foi lá, pegou a cruz, veio, subiu no palco aqui de novo, aí mostrou a cruz para o povo. O povo ficou horrorizado...

Aí, depois, não tinha jeito de que fosse chover, não tinha. Estava tudo limpinho. De repente, apareceu uma nuvem, aquela nuvem bem escura, assim como que viesse aquela nuvem andando, para chover. Aí, o padre foi e falou: "Vai cair uma chuva. Vai cair uma chuva muito forte. Vocês entrem na igreja. Vamos entrar na igreja, e se a igreja não der, vocês entrem nas casas do povo. Vai cair uma chuva muito forte". Aí, caiu mesmo. Caiu uma chuva forte, dava até medo.

Era boca da noite. A novena começava às 8 horas. E ela acontecia por pouco tempo. Hoje não, mas naquela época lá os padres falavam, e se eles falassem, podia contar.

Vamos que não fosse uma fivela mas, no meio do povo, o povo viu uma fivela. Naquela época eu era uma criança ainda. Eu me lembro muito bem. Aí, depois, no outro dia ele procurou o padre, pediu desculpa, tudo. Daí, depois ele largou de ser crente, não quis mais a religião de crente.

Era uma família muito rica, família que tinha riqueza. Riqueza de lá era assim... muito separada da pobreza. Na igreja tinha os bancos, mas eram bancos muito bem feitos para os ricos. A pobreza entrava lá e tudo, o povão entrava lá, mas aqueles lugares não podia ocupar, não. Porque tinha o nome, chamava "baronesa". "Baronesa", lá no Norte, é ser riquíssimo, sabe. "Coronel" é ser riquíssimo também. O nome de "coronel" e de "baronesa" lá era de pessoas que eram riquíssimas. Então, eles tinham a separação dos pobres. Na igreja, eles não sentavam junto com os pobres. Tinha o banco com o nome "barão" ou "baronesa", ou como que fosse assim, que não era para sentar ali, porque ali era deles quando eles viessem sentar, quando eles viessem para a igreja - e eles iam -, mas só que era tudo sentado naqueles bancos. Já era deles.

Agora, hoje eu não sei. Aquela raça lá daquela época. Hoje deve ter a raça, mas já acho que nem filhos deles não são. Já deve ser neto, bisneto, tudo, mas já coisa longe. Já passou muito tempo, né, Gustavo. Então era muito diferente.

Como uma vez eu contei aqui para você que a nossa igreja era longe de onde nós morávamos. Tinha que fazer uma base de 8 quilômetros ou mais. E a gente ia de domingo, a pé. Meu pai fazia aquele bandinho, que era dos filhos dele, e a gente ia para a missa. A gente saía cedinho de casa para poder alcançar a missa nas horas do padre. A pé. Não tinha condução, carro, não tinha nada. Então a gente ia.

Mas era assim, sabe Gustavo, era uma fé...Talvez que essa fé fosse uma fé viva, tão viva, só dentro do coração. Não era como hoje, que eu estou com você aqui na mesa, sabendo que você é da Igreja, sabendo que você está fazendo uma pesquisa comigo, para você levar alguma coisa não sei para onde, que eu ainda vou perguntar como que é bem direitinho, porque eu estou meio curiosa de perguntar onde é que você leva este trabalho, tudo. Eu sei que nós estamos aqui conversando tudo isso daqui porque Deus está aqui presente no nosso meio. Mas lá ninguém ia imaginar que Deus estivesse presente, não. Porque para nós, Deus não ia ficar presente no meio de nós, não, que era pecado. Porque lá, para nós, a gente não tinha merecimento.

A gente não tem merecimento, mas no nosso poder de ser humano... Eu acredito que Jesus, é Ele que é o Salvador, é Ele que nos cuida, é Ele que nos guarda, é Ele que faz a gente caminhar, é Ele que faz a gente dormir, é Ele que faz a gente comer, é Ele que dá força para os chefes trabalharem para trazer a comida pra dentro de casa. Eu tenho fé em tudo que é isso daí. Que não é feito nada disso se não for Jesus Cristo andando junto com a gente. Mas lá ninguém pensava assim, não. Nós sabíamos que a gente ia para a igreja, mas a fé era uma fé viva. Mas a gente não sabia explicar para você como era aquela fé. Se você me perguntasse 
sobre aquela fé, como agora nós estamos conversando aqui na mesa, eu não ia saber dizer para você por quê.

Vamos supor que as CEBs... as CEBs são só um meio de comunicação que foi descoberto para a presença do povo, para que a gente possa... Eu posso passar e tem um bêbado ali e eu não dizer nada para ele ou "que ele é um vagabundo". Ou eu ter até pena e ter até vontade de chegar lá e levantar ele dali. Eu já cheguei a levantar bêbado com limão. Pegar o limão, pôr bastante assim no pulso, e depois dar para ele cheirar. Ele levanta. Eu já cheguei a fazer isso. Eu com medo, né. Mas também tem uns bêbados que não deixam. Ele xinga.

E nós temos que fazer isso. As CEBs foram um meio de comunicação para a gente poder saber como é que a gente trata o nosso irmão. A oração ser uma oração forte para nós. Fazer a nossa oração, nosso retiro, mas de lá a gente achar que o retiro não é uma coisa qualquer, e que a gente tem que saber que daquele retiro vai ter que trazer alguma coisa linda, bonita, para eu dizer para você. Dizer para você que as CEBs são um meio de comunicação do povo para deixar o povo tranquilo, feliz, não chicotear.

Então, naquela época não era assim. A gente era simples, era uma simplicidade muito... como se fosse uma criança. Uma criança não é simples? Ela não sabe dissimular nada para dizer para mim ou para você. Então, naquela época era assim. A gente ia na missa, a gente fazia as novenas, mas eu não sabia que eu tinha que sair daquela novena para ir numa casa, pra dizer para aquela pessoa que aquela novena foi linda, que naquela novena ela achou uma coisa muito importante. Acabava aquela novena, acabou.

Por quê? Porque era assim que tinha que ser. Porque não tinha ninguém para explicar para a gente. Não tinha retiro. Não tinha o padre para explicar. $\mathrm{O}$ padre vinha com as costas viradas para a gente. O seminarista não sei o que era. Era assim, sabe.

Então, o que é que nós fazíamos? Nós éramos católicos vivos, de rama. A raminha plantada ali, e aquela raminha foi crescendo, crescendo... Sabe a rama do meu pai? Foi crescendo aquela raminha, e meu pai esparramou, e me deixou aqui com essa fé. E essa fé eu procurei. Eu procurei, a pulso, também de algumas outras coisas: alguma psicóloga, né. Eu tinha meus filhos, tinha meu marido, tinha tudo, mas eu mesma não estava sabendo... ainda estava com aquela besteira de não saber estimular nada em ninguém. E hoje eu sei. Eu não sei ler direito, mas eu sei dizer para você... Desde a época que eu estou na Igreja São Geraldo nunca fui de outra igreja. Porque as outras igrejas são todas iguais. Mas a Igreja São Geraldo foi a minha comunidade, onde, lá, eu pude imaginar coisas importantes, foi onde eu pude participar da CEBs, foi onde eu pude, de lá, esparramar para o povo o que é a Palavra de Deus.

Em favelas eu tenho conhecido. Conhecido da época desse trabalho. Naquela época lá os favelados eram tudo com aquelas casinhas que não podia nem entrar lá dentro. Mas eu entrava.

"Vocês querem fazer uma oração aqui? Uma reza?" A gente vinha em grupinho.

"Ah, eu quero".

"Pois a gente vem. Tal dia a gente vem". A gente chegava lá, não tinha nem onde a gente...

"Mas acontece que aqui não tem nem onde sentar...".

"Não, não tem perigo. A gente senta no chão. Se for possível a gente senta na caminha velhinha aqui mesmo. Não tem perigo, não". Aconteceu isso muito comigo. Então é assim, sabe. Lá em Água Branca não tinha como a gente fazer isso.

Lá, cada pessoa fazia sua oração e cada pessoa ia na missa, mas aquela fé era viva. Só que aquela fé a gente não sabia pôr pra fora, pra dizer para a pessoa que... Nós estamos numa tarde aqui que eu sei que está gostosa, muito gostosa mesmo. E tudo isso que eu estou falando, eu estou falando porque eu já aprendi. Naquela época eu não aprendia nada. Eu só ia e pronto. Eu ia e acabou. Não sabia, ninguém me dizia nada. Só ia na missa para não ficar 
sozinha, e meu pai: "Vamos". Chegava em casa, tudo bem. Hoje não. Hoje as CEBs são uma escola. Ela ensinou para a gente. Somos todos nós. Que nós somos filhos de Deus, e que Deus é nosso Pai. E que Ele cuida de nós. Posso dizer: "Não fica assim, não. Não fica triste, não fica deprimido, não fica com depressão, acaba com essa depressão, por favor, acredita em Deus. Que Deus nos cura. Deus nos cura".

Curou aquela época e cura ainda hoje. Mas Ele nos cura por quê? Porque nós sabemos sair de casa para ir na casa do amigo, fazer uma oração, fazer uma novena e dizer para aquela pessoa no Evangelho, na Palavra do Evangelho: "O Evangelho é assim porque foi Jesus que mandou a gente seguir. E essa palavra aqui foi Jesus que mandou a gente ler para dizer a vocês". Lá não era assim, no Norte, não tinha nada disso. Está entendendo? Hoje é diferente.

$\mathrm{Eu}$ acho melhor agora porque agora a gente tem comunicação. Se comunica. E lá não tinha. Lá, se uma pessoa chegasse e falasse para o meu pai assim: "Seu Pedro*, o senhor fez lá uma novena na tua casa...". Que ele fazia novena de Nossa Senhora do Perpétuo Socorro. Meu pai era devoto de Nossa Senhora do Perpétuo Socorro e fazia todo ano a novena. Mas se uma pessoa fosse atrás dele para sentar, fazer uma roda assim, e dizer: "Vamos conversar e dizer para o povo porque que foi que nós fizemos isso, e ver de lá de cima o que Jesus disse para nós". Aí, não tinha atividade. Hoje nós temos. Hoje eu não tenho vergonha de falar. Antigamente, eu tinha, mas hoje não tenho. Hoje eu sou feliz. Eu tenho tranqüilidade e sei falar a Palavra de Deus, que Ele está aqui com a gente. Ele está aqui com a gente. Lá não. Lá, se eu falasse para uma pessoa: "Deus está aqui com a gente", ele me vaiava. Diriam: "Deus não pode estar com a gente, porque nós somos pecadoras. Nós somos pecadoras. Como é que Deus vai estar com a gente se nós somos pecadoras?". Então é assim. Aqui não. "Deus está aqui com a gente, Ele está aqui com a gente, mesmo sendo pecadoras". Porque se eu souber que Ele está aqui com a gente porque nós somos pecadoras, aí eu já vou diminuir o meu pecado. Se fosse para pecar mais, eu vou pecar menos.

Então, hoje eu vou à missa, e quando eu volto, se for possível uma pessoa falar assim para mim: "Por que você foi à missa?", eu sei lhe responder por que foi que eu fui. Fui à missa porque foi Jesus Cristo que deixou. Ele fez a Santa Ceia e Ele deixou a missa para a gente seguir. E nós vamos porque nós não podemos ficar sem procurar Ele. Em casa, a gente procura Ele, mas não é tanto. Nós temos Ele dentro de casa, mas Ele não está com a gente como quando a gente está na igreja. Porque estando na igreja, a gente olha no povão e fica sabendo que aquele povo é tudo filho de Deus. Todo aquele povo que está lá rezando. Nem que tenha lá algum que não esteja rezando com muito gosto, que esteja com pressa, dizendo que o padre está demorando... Vem para a missa, mas como um passeio.

"Mas por que a senhora tem essa coisa com a missa?".

"Por que Deus deixou a missa".

"Como foi que Ele celebrou a missa?".

"Ele celebrou a missa. Ele fez a missa da morte, da paixão, consagrou a comunhão que é o corpo -, consagrou o vinho - que é o sangue".

"E as pessoas podem tomar sendo pecadoras? Eu sou pecadora, não posso tomar".

"Porque minha fé está aqui, ó. A minha fé está aqui. Vá lá também, vá lá também praticar nossa fé, vá lá também participar da missa".

"Ah, mas eu tenho preguiça, eu tenho sono".

"Mas por quê? Acorda, acorda. Você só dorme e dorme, depois vem me perguntar".

Ah! Outras falam assim pra mim: "Você já vai pra missa, reza pra mim?".

"Ah, vai lá também rezar". (risos)

Não adianta rezar para uma pessoa que está dormindo porque tem preguiça de ir à missa. Adianta um pouco, mas tem que se virar também. Tem que acordar, não é Gustavo? 
Você está percebendo que quando você saiu da tua casa para vir aqui, você está sentindo que não foi bem você que quis. Porque se fosse você que quisesse fazer isso, sem uma determinação de Deus, eu acho que não ia acontecer muito, não. Porque você é jovem, tem sua mulher, e você poderia dizer assim: "Bem, eu não vou, não. Eu fico tão pouco com você... você trabalha, eu trabalho, e agora quando chega na hora de nós ficarmos juntos, assim, os dois, eu vou ter que ir numa casa fazer isso e isso e isso. Eu não vou, não. Eu vou ficar com você um pouco". Mas o pouco que você fica com a sua mulher já é o suficiente para ela saber que você a ama.

Aí, você vai chegar lá e dizer: "Olha, Bem, conversei com a Dona Margarida. Ela conversa demais, fala muito, mas eu deixei ela feliz, deixei ela contente porque essa segunda vez nós conversamos coisas que eu nem sabia que poderia ter acontecido, que o crente atirou no padre, mas dentro do revólver tinha uma fivela", e naquela época também aconteciam essas coisas para o povo saber que existe Deus. Deus pode, de uma coisa, virar outra coisa. Ele praticou os pães, ele praticou os peixes, os animais para o povo comer, mas Ele também praticou dentro do revólver uma bala, porque o crente quis matar ele. Aquela fivela era uma bala, mas para mostrar para o povo que o padre mostrou, o povo viu uma fivela. Mas aquela fivela que o padre mostrou, foi para o povo saber que teve um milagre. Teve um milagre que não foi nem o padre que praticou, mas foi Deus quem praticou porque o padre estava trabalhando aquela obra de Deus e o crente veio matar ele.

É a mesma coisa aqui também. Aqui também é um milagre que nós praticamos. Se meu filho chega aqui e ele vê eu mais você aqui conversando, ele já dá: "Boa tarde, boa tarde". Ele está sabendo que eu sou dessas coisas, ele não vai me exigir: "Por quê? Com quem você estava?". Não. Ele já está sabendo. Porque quando vem já digo: "Olha, vem uma pessoa da Igreja aqui. É uma pessoa que vem. Ele vem me escutar, eu vou escutar, ele é uma pessoa da Palavra de Deus e essa Palavra de Deus tem que ser posta para fora". Ela não vai ficar aqui dentro. Porque se ela ficar aqui dentro, por que é que nós vamos juntando atrás de Deus? Porque nós vamos à igreja? Por que nós vamos no retiro?

É assim mesmo, sabe. Nós temos que praticar, pôr para fora.

Aí na Igreja São Geraldo não está mais acontecendo retiros. Mas aí já aconteceu retiro de 500 pessoas. Eu tenho até a jaquetinha que nós vestimos, dizendo atrás: 'CEBs'. Até o Cesinha tem. Já teve mais retiro, mas esse mesmo foi um retiro de 500 pessoas. Agora, você imagina que tem gente que até acolher uma pessoa no portão acha difícil, achando que pode ser um ladrão. "Vou acolher uma pessoa dentro de casa sem eu conhecer? Pode ser um ladrão. Pode ser. Eu não vou recolher uma pessoa na minha casa se eu não conhecer".

$\mathrm{E}$ as CEBs fazem um trabalho tão importante que se comunica com a gente, para que a gente receba o desconhecido, com confiança em Deus, e traga para dentro de casa, para dormir na nossa casa. Então, já aconteceram diversos retiros lá. Mas esse foi muito grande, teve 500 pessoas.

Aí, a comunidade se comunica, se reúne, junta o povo que vem, o padre fala quantas pessoas vêm, quantas pessoas eu posso receber, quantas pessoas você pode receber, quantas pessoas o outro pode receber, até terminarem os quinhentos. Que é para a gente recolher na nossa casa. Porque eles vêm para ficar sexta, sábado e domingo. São três dias.

Então, a gente combina naquele retiro para ficar sabendo que aquelas pessoas vão ser acolhidas na casa da gente, hospedados. Aí, eu vou e vejo quantos dormitórios tem, e quantas casas tem, e quantas caminhas tem. E eu pego as pessoas que minha casa tem condições de acolher. Aí eu vou lá falar assim, no retiro: "Bom, na minha casa vai ter três". Aqueles três eu vou ter a responsabilidade de sexta-feira estar lá. Aí, se juntam os três, e aqueles três são meus, três dias. Vou trazer para minha casa. Na minha casa eu vou dar o bolo, vou pegar o café, vou dar o banho, vou oferecer todas essas coisas. E também vou ficar disponível a ir 
para a igreja com eles, no sábado. Quando for sábado de manhã, eu tenho que ir com eles, e ficar com eles até terminar o trabalho do dia. E domingo também. Depois, domingo, levar para a missa, e terminar até o horário de duas horas, ficar lá com eles, vir almoçar e depois voltar para ficar com eles. Porque eu assumi. É muito importante isso aí, viu.

Eu poderia trazer duas pessoas. Aí, eu fiquei pensando... Naquela época lá meu marido estava vivo e ele também gostava. Aí, eu fiquei responsável por duas pessoas. "Ah, mas eu quero três. Sabe o que nós vamos fazer? Nós vamos colocar o colchão no chão. Eles podem dormir no chão para a gente poder trazer mais". Aí, chegamos lá, peguei três pessoas: dois para dormir em caminhas e um para dormir no chão. "Ele vai dormir no chão, mas ele vai vir". Desse jeito.

Aí, vem de tudo quanto é lugar. E aquelas pessoas eu pego sem conhecer. Mas eu trago elas para minha casa com confiança. Por quê? Aquelas pessoas estão preparadas para Deus. Eu também estou preparada para Deus. Então, eu trago as pessoas desconhecidas para minha casa, sem susto, sem medo, sem nada. Chegam em casa, aí eles vão e tomam banho, depois tomam lanche de noite. Quando eles chegam aqui na sexta-feira, dou um café, um suco, uma coisa, aí batemos um papinho e eles vão dormir. Quando eles saem, eles deixam cada carta para a gente! Eu tenho uma carta aí guardada que eles deixaram. Imagina, eles fazem um relatório tão bonito que dá para a gente chorar, sabe. Dizendo, dando valor para a gente, agradecendo o acolhimento... É coisa muito bonita. Esses retiros aí, a gente fez em muitos lugares.

Nesses retiros acontecia muita alegria! Vamos supor que fosse sexta-feira. Sábado, todo mundo tem que estar lá. Aí, a comunidade procura... uns fazem teatro, outros fazem cartazes para vir procissão, representando para o povo o que é o Evangelho, o que é a Palavra de Deus. E eles ficam tudo ali sentados, olhando. E a comunidade das igrejas, como a São Jorge, como Rio Grande da Serra, todos se preparam pra vir para a São Geraldo, com aquele preparo certinho, como que fosse uma São Geraldo só. Mas não é. Tem muitas igrejas juntas. Aí, quando nós vamos para lá, levar eles, é para ver tudo isso. Aí, tem o cântico, canta, canta. Aí, vem uma e representa uma coisa, vem outro e representa outra coisa. Vêm as crianças. Eles preparam as crianças do catecismo para mostrar a representação a eles. É um dia de representação muito bonita, que eles fazem tudo feliz. E a que acolheu está ali, animando eles. E ali todo mundo já virou amigo. Uma amizade pura.

Aqui mesmo nunca teve problema de água. Mas saem todas essas coisas. Sai tudo: como é que tem que poupar água, como é que tem que zelar pela água, como é que tem que poupar luz, porque que é que tem que poupar luz. "Não pode jogar fora, porque a água é pura, a água a gente tem que beber, e a gente tem que tomar banho, senão a gente não vive". Saem todas essas coisas.

Greve teve na época do Lula*. Uma vez eu fui. Em São Bernardo do Campo. É uma coisa enorme. ENORME, ENORME, ENORME, ENORME, sabe. Depois tem a igreja - acho que é Santa Terezinha... - que acolhe tudo, sabe. Até hoje ainda tem isso aí, esses acolhimentos. Agora, as passeatas, como aquelas do tempo do Lula, estão mais poucas. Mas naquela época, no tempo do Lula, o Lula subia no caminhão, com os alto-falantes, aquelas coisas. Ele saía. Aí, o povo saía tudo junto gritando, tudo atrás, com bandeiras, com cartazes.

Fui já umas duas vezes. Essa vez que eu fui, foi assim: eles pegam o caminhão, preparam com os alto-falantes, com os microfones, tudo. Enchem o caminhão. Aí, tem a pessoa que vai lá na cabine, que é para ir explicando porque é aquela passeata dos operários, porque que os operários estão fazendo aquilo, porque que tiveram as greves, porque os empresários não dão valor, não querem pagar como merece. Então, acontece que eles fazem 
para poder mostrar porque estão fazendo aquilo. E os empresários sabem de tudo e têm que aceitar.

Eles estão fazendo ainda. Eles fazem no Dia dos Trabalhadores. Agora, lá no Dia dos Trabalhadores, teve. Teve a missa, e eles fazem a passeata. Vai a São Geraldo. Vão todas as igrejas. Nessa vai Rio Grande da Serra, vai São Jorge, vai São Geraldo, vai a região da São Geraldo, que são todas as igrejas da região. Vai! Agora, eu nunca mais fui porque para mim é muito...

A gente fazia caminhada sabe para onde? Para o Pedroso. A gente ia para o Pedroso fazer caminhada. Umas duas vezes eu fui caminhando, daqui para o Pedroso. Levei até o Cesinha. Cesinha pequenininho assim. E eu pegava no braço dele e: "Vamos, filho. Vamos embora". E fui. Diversas vezes. A coisa mais gostosa! Cada qual leva lanche. Aí, chega no momento que é para relaxar, todo mundo senta, lanche comunitário, almoço comunitário, bate-papo, conversa sentado tudo junto. Já fizemos também - que esse ano já teve, mas eu não fui - o Passeio da Comunidade e Churrasco. Eles fizeram agora. Eu não fui porque, inclusive já tinha aparecido o negócio dessa doença aí. Mas eles fizeram. Aí, vai violão, vai tudo lá, faz o churrasco, todo mundo canta, todo mundo dança, todo mundo come. Tudo da Igreja São Geraldo.

O Centreville foi invadido. E foi o Perseu que invadiu. O Perseu preparou. Foi assim sabe: no Centreville, fizeram as casas, mas fecharam. Não alugava para ninguém nem vendia. Naquela época, tinha tanto morador sem moradia que era uma coisa demais. E eles fazendo trabalho, fazendo caminhada pelo mundo, pela cidade, com cartazes, com tudo, que não tinham onde morar. Perseu pegou - foi logo quando começou as CEBs -, aí o Perseu chegou, combinou com todo o mundo, falou assim: "Hoje de noite, a gente vai atabafar o Centreville. Cada pessoa vai entrar numa casa e não vai sair". Aí, juntou gente pra caramba, viu. Aí, fomos tudo a pé para o Centreville. No Centreville era tudo fechado. Não tinha moradia, não tinha nada e nem eles abriam mão. Aí, o Perseu vai, na hora que estava todo mundo preparado lá no Centreville - gente pra caramba! -, aí ele fala: "Agora vamos invadir". Aí, começaram a abrir as casas, e com pontapé e tudo, e cada qual entrava. Até hoje.

E tem mais outra, sabe: nessa época, a polícia invadiu, batia em gente, tudo. Teve uma época, que não sei por quê, eles prenderam o padre José Mahon. Não foi bem na época do Centreville. Isso daí foi outra coisa, que eu não me lembro o quê. Que a minha família, meus sobrinhos e tudo - eles agora não estão mais, mas nessa época os meus sobrinhos e o meu irmão, que tinha chegado do Mato Grosso há pouco tempo -, eles pegaram e começaram a comunidade da igreja. E a família dele era tudo jovem. Aí, a família dele entrou na Igreja São Geraldo também e tomaram conta das comunidades para fazer Coral, preparar a missa, serem comentaristas no momento da missa. Eles ficaram MUITO tempo. Aí, o padre José Mahon gostava muito... gostava não, até hoje ele gosta muito deles. Eram jovens, muito jovens, que eram filhos desse meu irmão, e eles tomaram conta da Igreja São Geraldo para essas coisas. Como hoje. Hoje não tem? Então, naquela época eram eles. Aí, eu não sei como foi, o padre José Mahon fazia com eles muita coisa a respeito dos pobres. O início de por quê eles fizeram isso, eu não estou lembrada. Mas fizeram. Teve um negócio de revolta dos pobres... revolta em favor dos pobres... na época de política, não sei como é que foi. Aí, eles pegaram e prenderam o padre José Mahon. E chegou a ir para a cadeia. E ele nem ligou. Só falou: "Estou aqui de peito e coragem. Vou fazer o que eu quiser". Ali tem fé. "Fazer o que eu quiser. Eu vou fazer o que eu posso, mais o povo do José Bento*”. Nossa família é Bento: José Bento, Fulano Bento, tudo Bento, né. "Eu vou me juntar com os Bento e nós vamos fazer tudo isso".

Naquela época, eu tinha entrado na comunidade de CEBs. Foi naqueles tempos. Eu estava muito entusiasmada porque parece que eu queria revirar o mundo do avesso para ver se todo mundo podia entrar nessa vida! Eu batia nas favelas, nas portas. Eu passava, eu via 
aquelas casinhas pequenininhas, passava no fundo e falava: "É ali que eu vou". Aí, passava um pouquinho, eu já estava lá. Eu saía pelo mundo fazendo sacola para dar pra eles, porque eles estavam morrendo de fome, estavam precisando. Eu fazia todas essas coisas. Aí, a gente juntava - eu com essa família, e padre José - tudo aquelas coisas. Era muito gostoso, muito divertido. Só que tinha coisas no meio assim que dava até medo. (risos)

A gente também não podia abrir muito a boca, né, Gustavo. Não podia abrir muito a boca porque eles ficam tudo com os 'olhão' assim, com os 'ouvidão' abertos, sabe, os políticos. Ficavam tudo com os 'ouvidão' abertos a respeito desse negócio. As CEBs chicoteou muito os políticos, sabe. Ela chicoteou muitos porque os políticos só faziam coisa errada. Você vê que eles faziam assim ó: quantas fábricas que botaram muita gente pra fora... Ficava aquela multidão de gente na frente das fábricas, parados sem trabalhar. Eles punham tudo pra fora. Eles ficavam parados, sem trabalhar. E não podia abrir a boca senão apanhava, senão batiam neles. Naquela época era assim.

É por isso que o Lula gritava. O Lula era muito a favor do povo, mas contra essas coisas, e ele gritava: "Um dia eu vou ser presidente. Eu não vou parar enquanto não for o presidente. Que é para eu ver tudo isso aí”. Ele fez um pouco disso daí, sabe. E ele ajudou um pouco o povo nisso.

Principalmente as caminhadas que teve lá em São Bernardo do Campo, era assustado, viu. Estava aquela caminhada, gritando. O povo tudo: "Ei, ei, ei!". Mas do lado, a polícia estava toda armada. Estavam tudo armados de cassetete. Se tivesse um erro, metia o cacete. Batia.

Quando tinha essas coisas assim, não é medo que eu tinha. Eu não ia, não era porque eu tinha medo. Eu não gostava de ver muita coisa assim, não, porque veja: eu sempre tive o Cesinha, menino pequenininho, assim, especial. Eu não gostava de ficar nessas coisas com ele. E o outro não gostava muito de ver essas coisas, não. Hoje ele tem uma cabeça muito de Deus. Às vezes eu fico pensando assim: o Serginho, o meu filho, ele não foi muito para a igreja, não. Mas ele tem um coração muito de Deus, sabe. Acho que Deus faz as coisas, assim, dependendo das pessoas. O Sergio, Deus pôs para ele ser mais aquele que conversa com as pessoas - quem estiver nervoso, ou que seja o filho, ou que seja a mãe, ou que seja a esposa, ou que seja outra pessoa. Ele se põe ao lado, para escutar, como você está escutando. Você vai falando e ele vai escutando. Aí, vem e fala: "Calma, calma. Não é assim. Deus quer assim". Acho que Deus dá os trabalhos para as pessoas, Gustavo, sem ser muito da Igreja. Meu filho Sérgio não é da Igreja. Inclusive, sabe o que ele é? Espírita. O Serginho passou para a religião Espírita. Na época, deu uma chicotada danada. Eu não queria de jeito nenhum. Eu fiquei até meio doente. Depois, eu falei com o padre Miguel*, e padre Miguel me aconselhou que eu não ficasse assim. Eles são espíritas, ele e a mulher. Só que eles não freqüentam aquele negócio de 'tenda'. É uma coisa de 'mesa branca'. Eu nunca fui. Eu já falei: "Meu fillho, eu não posso ir ver, nem vou". Mas também... ele tem um dom que eu vou dizer, viu. O que ele faz aqui dentro de casa, sabe, comigo, depois da morte do meu marido. O que ele faz, assim, com as pessoas. Se ele vir uma pessoa, se uma pessoa procurar ele numa hora dum sofrimento, porque está chorando, ou o que seja, ele põe a pessoa: "Vamos sentar, vamos sentar ali”. E ele escuta, ele diz, ele fala. Sabe, isso acalma. Quer dizer que já é um dom de Deus, mas é de outro modo.

Porque Deus dá o dom para a gente, Gustavo, não é só na Igreja, não. Deus dá o nosso dom. Desde quando a gente quer ser bom, Ele dá os nossos dons para a gente ser aquilo para o povo sem precisar ir muito na Igreja. Porque, às vezes, vai muito na Igreja mas não sabe se decidir. Na Igreja só é bom ir quem sabe se decidir, quem sabe ir mas sabe comprovar que vai porque gosta da Igreja. Que vai na Igreja mas não será orgulhoso porque está indo. Não vai ser orgulhoso com o irmão, que fica deitado, dormindo. Não vai ser orgulhoso com o irmão que não vai. Não vai dizer: "Mas você não vai na Igreja? Você está no inferno." Não é assim, 
não. Nós temos que ir para a Igreja, mas nós temos que ir humildes, dizendo assim: "Eu estou na Igreja, mas eu estou na Igreja porque eu gosto. Mas que da Igreja eu vou trazer aquilo que eu gosto, e vou dizer para o meu amigo e meu irmão que Deus também está lá".

Que Deus manda a gente ir para a Igreja... Porque a missa é uma coisa muito importante. A gente tem que assistir ela que é para a gente saber como foi que Jesus Cristo sofreu, padeceu, como foi que Ele fez aquela ceia tão linda com os apóstolos. Agora, se a pessoa vai para a Igreja, mas entra aqui e sai por aqui, é melhor não ir. Melhor ficar por fora e procurar uma coisa que vale para Deus também. Mas que faça. Agora, de ele ser espírita eu nunca gostei. Mas ele é. Também é um dom de Deus.

O meu trabalho... a minha caminhada - não é trabalho, que negócio da Igreja não é nada de trabalho, é caminhada -, a minha caminhada, que eu me prontifiquei na Igreja São Geraldo há trinta e tantos anos, quarenta anos já se pode dizer, eu comecei com o intermédio da CEBs. Que é como eu te falei. A psicóloga mandou que eu saísse da depressão, mas que eu fosse para a Igreja. Eu obedeci, mas obedeci a Deus, não foi a ela. Que foi um chamado de Deus que eu tive. Eu senti que foi, porque nesse dia eu não tinha médico para me dar remédio. E me deu vontade de eu ir, conversar com uma pessoa, para saber o que eu devia fazer para tomar conta dos meus filhos direitinho, já que Sebastião não podia trabalhar mais eu... Sebastião não podia viver mais eu porque ele tinha bar. Eu, como uma mãe, uma dona de casa, estava com dois filhos - um especial -, e eu estava assim meio sofrida, sem saber o que fazer. $\mathrm{O}$ amor eu estava dando para eles imensamente, mas só que eu estava meio perdida, sem saber como era que eu ia fazer, sabe.

Ontem eu estive na Selma. Eu estive na capelinha do padre Alfredinho*, no Grupo de Oração com a Selma. Ela cuidava do padre Alfredinho. Depois, o padre Alfredinho morreu e ela tomou conta da comunidade do Servo Sofredor.

Aí, além de eu visitar ela, nós fizemos uma reunião muito bonita. É uma coisa assim só para ver, para a gente ver um cântico. Vamos supor que eu coloco aqui um cântico na minha frente. E eu canto aquele cântico como se eu estivesse cantando no Coral. A Selma faz assim. E o trabalho daquele Grupo de Oração é feito a partir daquele cântico. Aí, ela tira as palavras do cântico, conforme as palavras de Deus. E ela explica para o povo, e faz a reunião com aquelas palavras de um cântico. Depois, ela mostra as figuras. Ela mostra figuras de gente sofredora. Ela mostra figuras de plantação, plantações de roça, foice e machado, essas coisas, para a gente pôr em prática aquilo lá, o que é aquilo, porque que é. Ou um pé de árvore, um pedacinho de água ou mar. Aí, ela vai perguntar e a gente vai ter que dizer, também para nós mesmos, ou pra eles lá, qual graça faz aquela água, por quê aquela água. $\mathrm{Ou}$ que seja a luz, o que é que a luz faz para a gente. É coisa muito importante.

Aí, de lá me deu vontade de passar lá na Dinha, que me falou assim: "Olha, a Selma vai viajar amanhã para Uberaba. Ela vai ficar lá com as freiras. E ela confiou muito que nós vamos ficar presentes lá na capelinha, para a capelinha não ficar parada. E que é para a gente fazer os mesmos trabalhos como se ela estivesse junto".

E eu não estou muito preparada, porque por causa dos problemas que eu tive - eu estou com o problema nos meus pés, que doem. Então, eu falei para ela que o que eu puder fazer, eu faço. Mas eu não vou garantir também, porque tem dias que eu não estou disposta para subir lá no sol quente. E, às vezes, sem carro... porque às vezes meu filho me leva, mas outras vezes meu filho não está para me levar e eu não gosto de subir esse reboco, num calor desses, quando eu não estou muito boa.

Aí, ela falou para mim: "Eu, sabe por que eu não assumi nada? Por que meu astral está muito baixo". 

baixo?".

Eu falei: "Mas qual é o astral seu que está baixo? Qual é o problema do astral, que está

Ela falou: "Ah, é o astral mesmo de caminhada, de ir para a igreja, de ir para essas coisas. Já falei para o médico. Meu astral está muito...”.

Aí, eu fíco pensando assim: esse de negócio de astral tem, existe. Só que meu astral abaixou mesmo, como ela diz, quando eu tive pneumonia primeiro. Depois, quando eu viajei, que eu cheguei, eu vivi. Eu estou com vontade de enfrentar, sabe. ENFRENTAR TUDO! Eu estou com vontade de ir para o Terço dos Homens com o Cesinha. Falei: "Cesinha, vamos para o Terço dos Homens, onde o papai frequentava, filho. Vamos chegar lá, você fíca lá no meio fazendo o Terço dos Homens no lugar do papai".

Ele: "Vamos mãe, vamos". E vou levar ele lá qualquer dia. Eu saio daqui, coloco uma bolsinha debaixo do braço, assim: "Vamos Cesinha?". Aí a gente sai andando. foi?".

Sexta-feira eu vou para o Coral, aí saio andando. Aí, o Serginho: "Mãe, a senhora

"Fui, filho, fui. Eu fui para o ensaio, voltei, um colega me trouxe". Mas quando um colega não me traz, eu venho sozinha dez horas, nove horas.

É. Então é isso aí o que as CEBs me trouxe. Porque eu comecei dessa época pra cá. Eu te contei que eu comecei dessa época pra cá. De quando a psicóloga falou: "Vai na Igreja que a senhora vai sarar. E pega o remédio do médico e joga fora". Cheguei em casa, joguei o remédio fora. Até hoje, eu estou levando, eu estou enfrentando. Quando eu esmoreço, é porque veio uma coisa que... Talvez, se Deus... Deus não teve o tempo Dele? Teve. Deus teve um tempo. Eu também tenho que ter meu tempo. Que eu falo assim: "Agora eu vou descansar um pouquinho. Eu vou na missa, mas eu vou voltar e, se tiver algum retiro, não vou, porque eu quero descansar". Por quê? Meu corpo já está cansado também, né. Já estou de idade... Só que minha idade também não está, assim, fazendo com que eu pare. Vai longe ainda, Gustavo. Vai longe... 


\subsection{Messias}

Vim da roça com 7 anos. Aí, a gente foi ver a miséria, sabe. Nós alugamos uma casinha, até que bonitinha, perto da Igreja, mas foi vendendo as vacas que tinha, foi vendendo a bicicleta, foi vendendo as coisas, e ficamos na miséria. Aí, eu fui trabalhar de babá. Minha irmã trabalhou em casa de família, meus irmãos foram tudo engraxar sapato, e meu pai continuava internado no Hospital Sanatorinho de Campos do Jordão. Acho que ele ficou uns 6 meses. E a minha mãe, para sobreviver, lavava roupa para fora. E aí, eu trabalhei como babá, na casa da mulher, acho que uns 4 anos. E cada vez que a gente ia ficando mais pobre, ia mudando de casa.

Fui morar na beira da estrada, perto de um rio, uma casa de madeira. $\mathrm{O}$ bom daquela casa é que ela tinha um quintal enorme, tinha muita fruta. E minha mãe criava galinha, criava porco, essas coisas, e aquilo ajudava na alimentação. E ela lavava muita roupa para fora. Tanta roupa para fora... Só que era assim: o pessoal explora muito, porque ela tinha que lavar aquele monte de roupa e ela ganhava uma miséria danada.

Aí, todo mundo começou a trabalhar. E eu trabalhei nessa casa. Entrei lá, a menininha da patroa tinha 4 anos. Não, tinha 8 meses. Quando eu saí de lá, eu estava por volta de 13,14 anos, quase para 15 anos. E depois a minha mãe conseguiu emprego de merendeira na escola, que foi uma benção, porque tudo o que sobrava na escola ela trazia para casa e matava a fome de todo mundo. (risos) Porque, então, já não tinha mais aquela fartura. Não tinha mais queijo, não tinha mais fruta - o que tinha no quintal. Não tinha mais comida, né. E carne era uma vez por semana só. Não tinha mais nada. Era só o cafezinho de manhã e pronto.

Aí, eu trabalhava na casa dessa mulher e estudava na parte da manhã. A minha sorte é que eu gostava muito de ler, lia muito. A patroa, às vezes ia viajar, largava eu tomando conta das crianças dela. Eu dormia no emprego. Muitas vezes eu dormia no emprego, e... enquanto as crianças brincavam - que eles eram tudo pequenininhos -, eu ficava lendo. Ela tinha muitos livros. E eu ficava lendo aqueles livros.

Lia MUITOS livros. Ia muito bem na escola, sabe. E era muito interessada em estudar. Gostava do saber. Gostava de aprender. Eu ia MUITO BEM na escola. Tinha notas boas na escola. E se tinha uma matéria que eu não soubesse... enquanto eu não sabia toda aquela matéria, eu não parava de estudar. E o meu irmão é quem me ajudava a estudar.

Quando eu fiz 14 anos - até arrumei um namorado -, eu olhei para a cidade, fiquei olhando o banco, os melhores empregos... Para quem eram? Filho de fazendeiro, filho do banqueiro, o filho do tenente, sabe. Aí, você ficava olhando aquelas meninas lindas que iam estudar em Penápolis, no colégio das irmãs, integral. Elas voltavam de férias para a cidade, assim bonitas. E a gente não tinha nada. Eu falava assim: "Ah, não tem nada para mim aqui".

Eu falei assim para a minha irmã: "Vamos embora daqui. Vamos embora daqui porque aqui não tem nada. Porque aqui, ou a gente vai trabalhar a vida inteira de empregada doméstica, ou trabalhar na roça. Puxa, eu não quero isso para mim. Eu quero uma vida melhor".

Aí, a gente veio embora. Doze horas de trem! Fomos morar na casa de minha cunhada. Aqui na Vila Pires. Perto dessa casa aqui. Aí, depois, a minha irmã arrumou emprego num hospital. Até foi o meu irmão que trouxe, largou a gente e depois voltou para a cidade. E aí ela foi trabalhar no hospital e eu fui trabalhar em casa de família, para dormir no emprego. Estava tão triste em dormir no emprego, sabia. É tão gostoso você trabalhar fora, mas à noite você volta para a casa. O meu lugar. Você tem a sua família. Mesmo que tenha arroz e feijão só, mas tem a sua família, né. O seu ponto de apoio. E a gente não tinha. Você ficar dormindo no emprego é coisa terrível que tem. Acho que eu fiquei uns 2 meses ali. E... a gente sofria muito assédio do patrão. A mulher dele saía, ele ficava. Eu trancava todos os quartinhos, bem quietinha lá num canto. Aí, chegou um dia que eu falei para ela: "Olha, não dá. O seu marido 
faz isso e isso". Ela falou: "Eu sei. Ele faz isso com todas as empregadas". Aí, liguei para a minha irmã, ela foi me buscar. Eu voltei para o interior.

Voltei para Braúna. Quando eu voltei para o interior, eu fiquei... acho que 1 mês. Aí, voltei de novo para cá. Falei: "Não vou ficar aqui, não". Aí, voltei de novo para cá. Fui trabalhar em outra casa de família. Que não tinha onde ficar, né. E aí eu também dormia no emprego. Eu acordava 7 da manhã e não tinha hora para dormir. A mulher tinha CINCO filhos. E ela era acho que professora e o marido dela, não sei, acho que trabalhava em banco. Só que eles saíam muito. Então, você tinha hora para levantar e não tinha hora para dormir. E ela saía e deixava aquele monnnnte de crianças. Tinha dia que eu não aguentava e eu... dormia. Aí, você acordava... um subia na lâmpada (risos), o outro subia na janela, o outro cuspia... Ai, meu Deus do Céu! E os caras tocaram a campainha, que eles moravam num apartamento e embaixo tinha um bar. Tocaram a campainha e me xingaram, e falaram que eu não dava educação para as crianças, que as crianças ficavam na janela cuspindo embaixo. (risos)

Aí, eu vim para cá, cheguei em 62. Em 63, a gente se reuniu, meus irmãos, todos eles, e acabamos trazendo os nossos pais. A gente alugou uma casinha e trouxe a minha mãe para cá.

Morávamos aqui na Vila Humaitá. Depois é que a gente foi morar lá na fazenda D’Ajuda. Aí, enfim, a nossa vida não melhorou de salário, mas melhorou assim, que estava todo mundo junto.

Fui trabalhar uns tempos de empregada doméstica. Mas eu tinha um irmãozinho que tinha uma doença na cabeça. Chamava hidrocefalia. Então, eu não podia me ausentar muito, porque ele dava muita mão-de-obra. Tinha que ter muitos cuidados com ele.

Aí, eu conheci todas as meninas do meu bairro. Comecei a trabalhar em fábrica. Me arrumaram em fábrica. Uma moça do interior, que era chefe na fábrica no Ipiranga, me arrumou para trabalhar na tecelagem. Aí, eu fui trabalhar. Eu tinha por volta dos 16, 17 anos. Foi quando, naquela época, acho que surgiram aqueles movimentos de... libertação da América. Que você já viu aquele movimento de Cuba.

Então, surgiram essas ideias. Porque, até então, a gente era... sei lá, não tínhamos direitos. Não tinha tempo para estudar, não tinha nada para a gente aquela época. Aí, eu fui trabalhar nessa fábrica e conheci o pessoal do meu bairro, que era da JOC - Juventude Operária Católica.

Aí, eu comecei a participar da JOC. A JOC era um movimento cristão. Era muito bom. Porque a JOC fazia olhar o outro com mais dignidade. Assim: o moço olhar para a moça com respeito, com dignidade. Que era tudo jovem, tudo adolescente. Tinha uns lá mais velhinhos, mas era tudo assim. Aí, convivia estudante da Poli, estudante do Ensino Fundamental, e operárias. Na JOC eram todos eles envolvidos num mesmo ideal.

As reuniões eram feitas na Igreja. Às vezes eram feitas em casa de família, às vezes nos colégios das irmãs. Aqui na região. E quando era encontro nacional, vinham jovens de todo o país. Então, era um encontro grande, cada jovem trazia suas experiências de trabalho. E era feito em colégios grandes. Bem grandes assim, para hospedar os jovens de outras cidades.

Mas o movimento da JOC veio mais para tirar os jovens dessa... acho que mostrar uma outra dimensão, uma outra ideologia, uma outra postura dentro da sociedade. Porque a sociedade não tinha políticas para nada naquela época. Tanto é que para você entrar no Ensino Fundamental, você tinha que fazer um ano de pré-cursinho. E só entrava quem era muito bom. E quem estudava em escola particular eram os que não conseguiam entrar em escola pública. Aí, eles iam entrar na escola particular. E hoje não, hoje é o inverso, né. Hoje é mais diferente um pouquinho. Porque o ensino mudou, mudou muito. $\mathrm{E}$ foi aí que a minha cabeça começou a mudar. 
Na JOC, os jovens convidam outros jovens. Os jovens que estão na Igreja mesmo. É um movimento de libertação dos jovens mesmo. Eu lembro que foi a Célia que me convidou. A Célia é irmã da minha cunhada. E ela era da JOC. Mas, quando eu entrei na JOC, já tinha muita gente participando lá do bairro. É que a gente não sabia. Só trabalhava e estudava a noite. E eu gostei do ambiente. Porque o movimento preenchia o vazio dos jovens. O seu vazio era preenchido com amizade. Com formação política, formação da fé. Então, os jovens se juntavam para fazer várias coisas, assim, por exemplo: atuar no movimento estudantil, atuar dentro da fábrica. A nossa ideia era mais assim de humanização. De cobrança social, de cobrança de justiça social mesmo. Então, eu acho que foi um movimento muito bom. Aquilo ali, conforme dava aquelas informações, você ficava... Para você ter ideia, a gente fica melhor do que advogado. Dos direitos, sabe, Gustavo? Porque, olha, você começa a enxergar como a sociedade funciona. Que a gente vem do interior muito assim... muito aquelas culturas da roça, muito simplório, muito puro, né. Então, depois, você começa a enxergar a sociedade como ela realmente é.

Eu me casei em 73. O padre Mahon* eu conheci em 63 quando eles vieram para o Brasil. Vieram vários padres franceses. E eles eram os nossos mentores na JOC, que davam assistência espiritual. Conversava, sabe.

Tinha o padre Ivo*. Tinha outros padres. Tinha o frei Francisco*, de Osasco, tinha o padre Álvaro*, de São Paulo, e tinha vários padres envolvidos nesses movimentos de jovens.

Eu acho que foi um momento bom, um momento que dá para você ter uma visão diferenciada da sociedade. E ensina você a lutar pelos seus direitos. A primeira coisa que eles pregam é você não ser aquele jovem consumista. Você encarar sua realidade sem ser com o consumismo. E a segunda coisa que eles pregavam era a igualdade dos jovens. E respeitar, não ter diferença de raças. A gente batalhar com vários jovens, de várias raças, de cor. Então, era uma coisa... era um momento muito bom.

Depois nós nos casamos, e eu fui ser catequista na Igreja. Aqui na São Geraldo. Quando a gente se mudou para cá, o bairro estava começando. Não tinha asfalto, não tinha água, não tinha nada. Aqui era tudo mato. E era água de poço. Todo mundo tinha o seu poço. E quando a gente se mudou para cá, eu tinha uma menina pequena, de 4 meses, e falei assim: “Ah, não quero água de poço, não". Aí, ele colocou água. Depois é que veio o asfalto, que veio a urbanização das ruas. Depois. Antes não tinha nada aqui.

Quando a gente se mudou para cá, os ônibus paravam perto da Vila Humaitá. Depois é que foi se estendendo para cá. E era barro puro. Aqui, você olhava o morro, não tinha quase casa nenhuma. Até o Centreville, era só mato quando a gente se mudou para cá. Era um lugar assim bem... bem pobre.

Quando nós casamos, nós moramos uns 3 anos ali no Parque Novo Oratório. Depois a gente veio para cá. Então, a gente estudou. Ele estudou, ele fez faculdade. Eu também estudei. Terminei o ginásio, daí fiz o colégio - mas o supletivo. Aí, eu passei na faculdade... Eu queria fazer Letras. Naquela época, quanto mais pontuação você pegasse, mais se aproximava da matéria que você queria. A minha pontuação foi 68, 69, e eu peguei Sociologia. Para pegar Letras, tinha que ser acima de 70 a pontuação.

Mas aí tinha a opção, né. Estudar os dois não dava, porque o dinheiro era pouco. Então, a gente optou por ele estudar e eu fiquei sem estudar. Aí depois, em 76, nasceu a minha filha. E foram nascendo os filhos. Aí é que eu não fui estudar mesmo.

\footnotetext{
* As pessoas citadas e marcadas com este sinal correspondem a seus nomes reais. A marcação de nomes reais só acontecerá na primeira vez que o nome for citado nesta narrativa. Todos os demais, sem esta marcação, tiveram seus nomes substituídos por outro, fictício. A decisão sobre a manutenção de alguns nomes reais entre os nomes fictícios foi tomada junto com a narradora.
} 
Depois, quando o Mahon veio para cá, eu comecei a participar do grupo da ADC Associação das Donas de Casa. Era muito bom, que reunia médicos, para visitar... fazer reuniões sociais, para discutir as necessidades do bairro. E eu comecei a participar. Depois, eu saí da ADC, porque acho que o movimento parou e eu entrei para ser catequista. Depois de catequista, eu fui ser ministra. Depois é que eu entrei para os Grupos de Rua, das CEBs. Acho que foi em 81, 82, que eu entrei.

Esqueci de falar do AI-5, das lutas dos jovens... Quando a gente estava na JOC, a gente se reunia muito para reivindicar justiça social, porque era proibido qualquer movimento social. Então, a gente se reunia em lugares muito assim... fechados. Mas sempre tinha alguém que dava informação para a polícia. Quando a gente pensava que estava tranquilo, fazendo a reunião, a polícia baixava. O que a polícia fazia? A gente saía escondido, correndo, e sumia. Cada um se dispersava e ficava lá até três, quatro horas da manhã. Depois é que a gente ia voltar para casa, de madrugada. Então, às vezes você... Por exemplo, vão tudo se reunir, vai pichar os muros, né. Aí, escrevia assim: "Abaixo a ditadura", não sei o quê... essas coisas de jovens. Aí, um ficava olhando. Se a polícia baixasse, você largava tudo e, se pegasse, a coisa era feia. E tinha os que ficavam de espião, para olhar jornalistas e policiais. Jornalistas vinham para fotografar, aí eles arrebentavam as câmeras porque... para não... a gente não deixava os nossos rostos serem fotografados. Para não sermos identificados, entendeu? Depois, tinha que distribuir panfletos. Aqueles panfletos eram super perigosos. Você tinha que ir de casa em casa. Era um trabalho noturno para distribuir panfletos. Convocando as pessoas para a assembléia, para as reuniões. Para questionar essa ditadura... que a gente então... queria questionar isso daí. E aí, a gente fazia isso tudo de madrugada.

Uma vez eu fui numa reunião do Monsenhor, ali na Príncipe de Gales. A reunião foi na casa dele. Mas quando estavam sentando todos os jovens para se reunir... a polícia. Nossa! O padre abriu a porta do fundo e todo mundo ó... Meu Deus do Céu! No meio daquele mato, daquela cerca, sumimos, nem sei onde foi, nem lembro onde foi. Que a gente correu, correu, correu, mas eles não pegaram a gente, não. Mas aí... (risos) Aí fugimos.

Cheguei em casa às três horas da manhã. Mas eu tinha um amigo. Meu amigo era muito positivo, que era o meu pai. O meu pai pegava todos os panfletos. A minha parte, ele distribuía. Ele punha uma capa de chuva - eu nunca esqueço (risos) -, ele enchia os bolsos de panfletos e ficava na estação. Escondidinho lá, passando os panfletos. $\mathrm{O}$ meu pai achava legal as coisas que eu... Ele dava ênfase. Ele me apoiava. (risos)

Era muito legal. Minha mãe também. Ela acolhia muito bem os jovens que iam. Olha, foi uma fase assim de... sei lá... acho que foi uma grandeza muito grande, porque você desafia. É um desafio, né. Desafia, porque... o medo, as estruturas. Que era uma estrutura montada, muito repressiva. Você não tinha direito a nada. Você andava na rua, se não tomasse cuidado, você levava cacetada. Era preso e sumia. Nossa, muitos amigos nossos sumiram. Nunca mais... que participavam das nossas reuniões. Nunca mais a gente viu eles.

Quanta gente sumiu. Quanta gente mudou de lugar e ficou escondido no mato. Sumiu, foi morar no mato, porque era muito perigoso. Principalmente para os que eram os dirigentes nacionais. Os cabeças eles cortam, porque cortando o líder... enfraquece os movimentos.

Igual o Rainha*. Corta o líder - qualquer líder... ou aquele lá, o Lancelot*. Aquele Ali Khan* também. Lembra o que fizeram com ele? Corta. Morre, acabou. Entendeu? É isso que eles fazem.

Os movimentos se dividiam em vários. Por exemplo, hoje é aquele, amanhã já se transformava em outro movimento. Até que os caras se descaracterizavam um pouquinho para não ficar muito visível. Para não ser pego fácil. Então, você se dividia em vários movimentos, mas tudo no mesmo ideal. Interessante, né? 
O MR-8 pegava em armas. Não sei quais eram as táticas deles, que eu fugia dessas coisas, morria de medo. Eu acho que a JOC já era bastante perseguida. A JOC não pegava em armas nem nada.

Tinha o MR-8, e tinha também a Convergência Socialista. Eu não conheço ninguém da Convergência.

\section{ROBERTO*}

A Convergência Socialista, se eu não me engano, o Wagner Lino*, que foi vereador de São Bernardo, e foi deputado estadual, era da Convergência Socialista. Era daquele PT bem radical mesmo, quando o PT era bem radical. Era daquela linha bem radical.

\section{MESSIAS}

A gente não gostava de entrar com eles. Porque eles entravam nos movimentos das CEBs e da Igreja e botavam pra quebrar.

\section{ROBERTO}

O negócio deles era a luta armada mesmo.

\section{MESSIAS}

Luta armada.

\section{ROBERTO}

Era tomar o poder à força. Custe o que custar.

\section{MESSIAS}

Eles entravam no meio das passeatas da JOC, dos jovens. E os jovens reivindicavam, assim, melhoria de salários, mais tempo de estudo para os jovens, universidade melhor para todo mundo, essas coisas. Eles entravam no meio e faziam a maior baderna, arrebentavam as coisas, arrebentavam banco. Ixi, eles eram da pesada. Quando eles entravam no meio, a gente... Depois, a própria polícia entrava no meio e falava que era o pessoal da JOC que fazia. E não era. Até, às vezes, a polícia entrava, arrebentava tudo para incriminar os movimentos. Eles faziam isso.

Nós éramos mais da base. Na Paulista, a passeata que teve lá... até aquele governador que levou tomate podre lá. O pessoal levou um monte de ovo podre, tomate. Esse governador foi fazer palestra, foi falar com o povo. O pessoal entrou, na passeata, na Paulista, arrebentaram tudo. Entrou Convergência, com polícia, virou um auê. Aí, encheram esse governador de tomate podre, de coisa, nossa, fizeram uma nhaca. E eles foram, e aqueles bancos da Paulista ficaram tudo arrebentados. Mas quem fazia? A Convergência e o pessoal da polícia. Depois jogaram a culpa nas costas da JOC. Por isso que a JOC foi caçada, "que era terrorista, que espalhava terror. Onde ela passava, destruía tudo". Quer dizer, era terrorista.

\section{ROBERTO}

Eles mandavam destruir para...

\section{MESSIAS}

... Para jogar a culpa e falar que a JOC era terrorista. E não tinha nada de terrorista.

\section{ROBERTO}

É uma maneira de eles terem um argumento para poder perseguir. 


\section{MESSIAS}

Lógico. A nossa revolução era de ideias, não era de armas. E a deles era de pegar em armas mesmo. Então, eles destruíam e falavam assim... por isso que nós fomos caçados. Depois que caçaram a JOC, acabaram os movimentos. Ninguém se arriscava mais. Ninguém abria o bico para nada, nem falava.

Na Igreja, o Partido Comunista não vinha. Pode até ser que eles tinham essas ideias assim, mas nos movimentos da Igreja, não. Eles tinham essas ideias socialistas. Isso tinha. Sociedade igualitária, igualdade para todos. Isso eles tinham. Por isso eu falo, talvez veio da Revolução do Che Guevara*, da Revolução Cubana. Influência da Revolução Cubana. Então, acho que isso tinha, sim. Porque quem não sonha?

O pessoal lia muito Karl Marx*, lia muito da Revolução Cubana. E comentavam, sim. Na JOC. Os jovens, os cabeças. A gente não era muito assim. Ficávamos mais na base, na Igreja mesmo. Mas as lideranças acho que estudavam tudo isso. A partir dessas ideias, da América Latina, depois com o Golpe Militar, acho que eles devem ter partido para aí: liberdade, ter mais liberdade para tudo.

A gente não tinha liberdade para nada. Era trabalhar. Quem trabalha em fábrica, sabe: é muito duro, é terrível. Você é escravo. Você trabalha sete da manhã - a hora que eu entrava -, e saía vinte para as seis, para chegar na escola na segunda aula; para chegar em casa meianoite; levantar quatro e meia da manhã, para você tomar um banho de lata - que não tinha nem chuveiro naquela época -; pegar o ônibus cinco e vinte; o trem seis e dez da manhã, para entrar na fábrica às sete. Aqueles trens assim... lotados. Tinha dia que a gente saía pela janela. Quando não amassava suas marmitas e seus garfos. É vida? Não é, não. Até hoje é assim. É um trabalho escravo, sabe. Por isso que o pessoal, às vezes, se revolta. Se não houvesse essas lutas não haveria mais justiça.

$\mathrm{Eu}$ acho que é por causa disso, Gustavo. Acho que o pessoal... Até hoje é assim, né. Quem trabalha em fábrica, quem trabalha em lojas, principalmente no final do ano, trabalha desde as nove da manhã e sai meia-noite. E só recebe depois que terminar o balanço da empresa, que fechou.

Agora voltando para a CEBs, foi quando começou um movimento forte de libertação mesmo. E já começou bem antes. Eu entrei só depois que eu vim morar para cá. E aí, nós começamos a nos organizar. Para armar... para essa abertura. Para essas Diretas Já. Aí, foi quando foi fundado o PT. Foi no Tancredo Neves* essa abertura social. E todas começamos a trabalhar nos movimentos de rua. E junto com esse povo. Porque CEBs é assim: são as Comunidades Eclesiais de Base NA BASE. A Igreja desvincula, aquela Igreja fechadinha lá. Todo mundo sai para as ruas.

E com essa Teologia da Libertação, do Clodovis Boff*, e do irmão dele lá, do Leonardo Boff*, foi uma coisa que trouxe um outro rosto para a Igreja. Então, essa outra dimensão para a Igreja. E a gente começou a trabalhar em cima da Teologia da Libertação. Que atrás da Igreja tinha o rosto de um povo. Não era só uma Igreja, é um povo que sofre, que precisa de comida, de emprego, de justiça social. Então a gente começou a trabalhar essa questão na base. A gente começou a ver o que faltava no bairro. E começamos a nos organizar para reivindicar, por exemplo, pelo ônibus. Demorava uma hora, uma hora e pouco para passar. Até mais.

Os ônibus vinham lotados. Então, a gente começou a fazer pesquisa, começou a trabalhar... assim, ir nos pontos de ônibus, começou a anotar, fazer planilhas, e começamos a reivindicar. E cobrar do prefeito uma postura, uma melhora. E melhorou.

E faltava creche. A gente se organizou. Eu lembro da primeira mulher que eu levei para falar na Câmara que precisava de creche. Ela mora até hoje no bairro. Muito interessante 
isso aí. Ela foi a primeira mulher que nós levamos, que era uma mãe que precisava de creche. $\mathrm{E}$ a gente se reunia em torno dessas mulheres que tinham as suas necessidades.

Porque, naquela época, a gente trabalhou muito na base, na gestão do Celso Daniel*. E quando não era o Celso Daniel, a gente ia lá e a prefeitura não recebia. A gente se pegava num vereador, que mais ou menos ia e recebia a gente. Mas não recebiam a gente. É... Eles nunca atenderam assim, eles não tinham política pública voltada para o social. Tanto é que os bairros viviam cheios de entulho. Não tinha nada, nem uma benfeitoria nos bairros.

Como está acontecendo hoje: pode ver o Centro, o Largo da FEFISA está ficando bonito. A Dinah Zecker*, vice-prefeita, está fazendo uma beleza lá. Mas os bairros estão parados. Não tem mais aquela... não tem mais movimento igual de mobilização de Igreja.

Tirou o MOVA. Os postos de saúde ficaram por vários meses sem médico. Não tinha médicos nos postos de saúde. Então, não existe, assim, política para o bairro. A escola, o posto de saúde, está tudo abandonado, sucateado. Então, a gente trabalhava em cima dessas questões. E também trabalhamos muito a questão do transporte.

A água. Nossa! A gente fez muita...

\section{ROBERTO}

Que aqui é um bairro alto, e a alegação do Semasa era de que faltava muita água porque não tinha bomba o suficiente, ou pressão suficiente para encher as caixas d'água. Então, demorava para chegar a água num lugar alto. E a gente ficava... amargava bastante falta d'água. Daí, quando começou a insistir com os movimentos, reivindicações, ir atrás, aí eles começaram a instalar bomba, começaram a melhorar, e até melhorar o atendimento. Daí resolveu o problema. Mas antes era falta de água direto.

\section{MESSIAS}

Antes, nós tínhamos o movimento de favelas. Então, tinha vários líderes das favelas. E a água não chegava nos morros, faltava água direto. E mesmo aqui, a gente morava nessa rua, não tinha água. Eles faziam um rodízio. Então, o rodízio era assim: eram dois dias com água e um dia sem água. Um dia com água e dois dias sem água. Só que enchia a parte de baixo, e quando chegava a vez de encher as nossas caixas, não tinha. A gente nunca tinha água. Aí, reuniu todo o pessoal de cima das favelas. Reunimos e pegamos um vereador da Câmara - que naquela época já era a gestão do Celso Daniel, e que a gente batalhou para conseguir que ele entrasse -, e aí ele foi com a gente até o Semasa.

O seu Miguel* participava muito. Tanto que o nome dele foi dado para a caixa d'água. Foi uma pessoa assim, que batalhou bastante. E teve um dia que nos reunimos em 200 pessoas, a pé. Descemos aquele morro... Ah, que coisa mais linda, sabe!... Muito legal assim... Aí, chegamos lá, aquele monte de gente... Ah, na hora o cara... Lá no Semasa. Falamos com o diretor do Semasa. Aí, ele ligou para casa e falou assim: "Olha, Messias, fica sossegada que no seu bairro nunca mais vai faltar água. Começou a fazer uma caixa que vem do Guarani, que vem aqui na Progresso e uma caixa lá em cima. E essas caixas vão bombear água para cima e para o seu bairro. Não vai faltar mais água”. Não valeu? Valeu o movimento.

A gente já estava batalhando nisso há mais tempo. Mas só na gestão dele é que a gente conseguiu.

\section{ROBERTO}

É porque era do PT, que é um partido mais voltado para a esquerda, mais com os movimentos sociais... 


\section{MESSIAS}

É, as políticas dele eram mais voltadas para o social. Porque antes de ele entrar, os nossos Grupos de Rua batalharam muito. Até a Miriam* e o Daniel vieram em várias casas. Até então, ela estava casada com o Celso Daniel.

\section{ROBERTO}

Uma vez eu tive uma reunião com o Celso Daniel e com o padre Mahon.

\section{MESSIAS}

É. Sobre a questão dos ônibus, transporte.

\section{ROBERTO}

Foi muito legal.

\section{MESSIAS}

Teve várias reuniões com ele a respeito do transporte público.

\section{ROBERTO}

Eu me lembro que ele fazia o orçamento participativo. Ele se reunia num bairro assim, e reunia as necessidades prioritárias do orçamento do próximo ano. O povo mesmo é que mencionava o que era importante naquele bairro, o que o bairro estava precisando. Eles iam anotando para poder trabalhar em cima daquilo.

\section{MESSIAS}

Só que nunca realizavam, porque você sempre tinha outras prioridades. (risos) É inteligente a política dele.

Mas aí chegamos à questão das planilhas. "Vamos pesquisar onde?". Aí, a Kombi passava em casa. Sempre tinha alguém que levava a gente, deixava nos pontos, quatro e meia da manhã. Você tinha que estar nos pontos. Até tal hora, alguém ficava; até tal hora, outro ficava. Ficava até dez, onze horas da noite. Até o ônibus parar. Sempre tinha alguém ficando e anotando na planilha. Vendo quanto tempo o ônibus demorava, qual o trajeto, para onde ele ia, e quanto tempo ele ficava parado na garagem. A gente fez uma planilha e fomos. Reunimos 100 pessoas e fomos lá no gabinete do prefeito conversar com ele. E aí, a gente pegou e ele falou assim: "Olha, 100 pessoas não quer dizer nada para mim". Isso quem disse foi o Celso Daniel. Mas nós insistimos. Eu sei que a gente depois juntou com vários movimentos de outros bairros, junto com a secretária de educação, que naquela época, na primeira gestão, foi a Nakano*. A secretária da educação era ela. Nos reunimos com ela - não tinha nada a ver, educação e transportes -, e fomos falar com ela a questão do transporte. Aí, reivindicamos.

Eu sei que a gente conseguiu que a prefeitura bancasse uma porcentagem do transporte coletivo e que não cobrasse mais por pessoa. Porque cobrando por pessoa, o ônibus demorava muito. Aí, no horário de pico não passava ônibus. E quando passava era super lotado. Então esperava aquele monte de gente. Porque ganhava por passageiro. Aí, passou a ser por quilômetro rodado. Aí melhorou o transporte.

Além disso, eles davam treinamento para os motoristas: como devia tratar o idoso, como tratar o passageiro. E faziam aquela cobertura dentro dos ônibus, explicando para os passageiros as mudanças que havia. A gente fez muito trabalho assim.

Depois nós também entramos lá no capítulo da saúde, com o Fernando Galvanese*. Ele era o secretário da saúde naquela época. E a gente foi... a Maria José*, aquele dentista... o Louzada*, e várias entidades de outros bairros. Nos reunimos, na Câmara, para reformular a 
Lei Orgânica do Município. A gente trabalhou a questão da saúde, a questão social, o Estatuto do Idoso, de colocar bancos para idoso, bancos para cadeirantes, bancos para gestantes. A gente colocou tudo na Lei Orgânica do Município. E na questão das creches, aí a gente batalhou... e... na questão também da saúde, dos postos de saúde.

Nós tínhamos muita assessoria na saúde. Porque vinha psicólogo trabalhar nos postos de saúde, para trabalhar com as mulheres. As mulheres têm muitas dúvidas de menopausa, de doenças, sabe. Então, é aquela abertura muito grande. Nas favelas tinha as assistentes sociais, as psicólogas, que vinham ensinar a trabalhar com aquela comida alternativa, de restos de folhas, folhagens, pozinho, essas coisas assim, para aumentar a nutrição das crianças das favelas. A gente fez muitos cursos com as mães. A gente trabalhou muito essa questão desses cursos aí.

E depois fomos reivindicar as creches. Aí saiu. Nós conseguimos creche. Conseguimos transformar esse parque, que estava abandonado. Um parque de lazer... O Parque Guaraciaba. E a gente tinha guarda, tinha tudo. Mas a questão é que o Celso Daniel desapropriou o parque, mas não pagou, deixou para o outro. O outro não pagou, ficou sem. Ficou enrolando a dívida. Aí, foi ficando mais cara essa área, e devolveu para o dono. Eles queriam fazer um aterro sanitário ali. E nós não deixamos.

\section{ROBERTO}

O pessoal se uniu para tomar a frente, para não deixar. Foi novamente o movimento popular se unindo que impediu que eles transformassem em lixão. Senão, hoje seria um lixão aí. Pelo menos permaneceu área verde aí.

\section{MESSIAS}

Então, a questão do tanque era que a gente se organizava porque morria muita criança. Tinha muito afogamento. Nós chamamos os bombeiros para eles fazerem um estudo da área, um mapeamento. Os bombeiros vieram, fizeram um estudo da área. Era para construir o parque. Como é que ia fazer com esse parque, que só tinha água? Desapropriar a água? (risos)

Não vão construir. Aí, tinha projeto de reflorestar, fazer um monte de coisas interessantes. Até eles fizeram quadra de esporte, trilha de caminhada, tinha guarda municipal todo dia. Nossa, dava uma segurança tremenda.

A escola, naquele tempo, que a gente trabalhava no Grupo de Rua, a gente fazia muita festa junina. Porque essas festas juninas, elas se organizavam em vários bairros. E a festa junina unia muito as pessoas da rua. Que a gente trabalhava assim: tinha um grupo que organizava a festa junina e, nessa organização, saía quem ia brincar com as crianças. Cada um ia fazer um trabalho lá na festa. E enfeitar a rua era o problema das crianças. As crianças levantavam cedinho e já iam com bandeirinha, picotar, buscar bambu. E foi muita gente buscar bambu com as crianças. Enfeitar a rua. E a Igreja emprestava aquelas barraquinhas, porque era festa junina. Tinha festa junina, então eles emprestavam para a gente. Depois a gente devolvia no outro dia. E a gente fez uns três anos festa junina assim. Três, quatro anos. E a gente cobrava bem baratinho. E esse dinheiro, a gente punha ele numa caixinha - tinha a tesoureira -, e a gente pagava sempre uma excursão para todo mundo da rua. Para quem quisesse participar: criança, adulto... E aqueles que não tinham poder aquisitivo para pagar a passagem do ônibus, que já era a metade do preço, a caixinha cobria. Então, ninguém passava necessidade. Quem não tinha dinheiro para o lanche... A gente fazia tudo em comum. Uns bancavam o lanche, e tudo.

Uma vez, nós fizemos excursão para o zoológico, outra vez fizemos uma excursão para o canal da TV Cultura, que era aquele programa Bambalalão. Foi muito legal. A gente 
levou todo o pessoal para o programa do Bambalalão. E o pessoal ajudava, vinha em peso ajudar.

E todas as crianças dançavam. Era uma coisa muito bonita. É gostoso você ver todo aquele povo trabalhando junto. Chegava na festa, estava tão cansado de organizar as coisas... mas só de ver aquele povo, todo mundo construindo uma mesma ideia, trabalhando junto. É isso que era legal. Que é o ideal da JOC, das CEBs.

Então, a gente fazia o trabalho assim. E o dinheiro que sobrava, a gente comprava muita cesta básica, dava um pouco para a Igreja - conforme arrecadava, mesmo vendendo baratinho. E a gente ganhava muita coisa. Ganhava MUITA. A rua inteira colaborava doando coisas. Mas só que revertia em favor de todo mundo. E a gente comprava... cuidava de comprar remédio para quem estava doente; ajudava quem estava desempregado na rua; se tinha alguém que não tinha... destelhado a casa, a gente comprava telha; todo mundo se organizava e ia lá ajudar; fazia a casa dele. A gente via a necessidade de cada um e a gente ia trabalhando em cima disso com o dinheiro. Não ficava nenhum tostão para a gente. Nesse sentido, era organizado.

Aí, bem antes do começo da gestão do Celso, a gente começou a organizar os sacolões. A gente participava da reunião lá em São Bernardo: que era eu, o seu Miguel, a Zilda, o Dino, o Lauro - até que ele foi candidato algumas vezes. Ia lá em São Bernardo, no sacolão de São Bernardo, no espaço da prefeitura. E a gente começou a ter as reuniões dos primeiros sacolões. Os primeiros sacolões vinham de caminhão entregar na Igreja. Então, todo mundo fazia o seu pedido: queria batata, arroz, o que ele quisesse. E o caminhão comprava direto do produtor e trazia para as comunidades. Cada um ia pegar o que tinha encomendado. Foi assim que começaram os sacolões.

O primeiro começou em São Bernardo. De lá se espalhou para cá. Aí, eles construíram um na Cidade dos Meninos e um aqui na Vila Luzita. A ideia era essa: de comprar direto do produtor para o produto sair mais barato na mesa do consumidor. A ideia era assim: levar comida para quem não podia comprar comida. Porque saindo do atravessador, a comida chega mais barata à mesa. Então você vai consumir mais frutas, mais legumes. E a população se torna mais saudável. A ideia desse sacolão era essa: fazer esse sacolão para o povo comer mais fruta. O seu Miguel falava assim: "Vocês vão poder comer alface, comer isso, comer aquilo, comer bastante verdura, bastante fruta, porque vai sair tudo baratinho para vocês". Porque onde tem atravessador encarece muito. Então, os sacolões estavam fazendo isso: ir buscar direto do produtor, das cooperativas, porque vende mais barato. Então, foi um momento em que eu acho que as CEBs ajudaram muito.

E, então, a ideia das CEBs é uma ideia... uma coisa fundamental na vida das pessoas de baixa renda mesmo. Deu a oportunidade para as pessoas poderem ter acesso às coisas. Porque o pessoal é marginalizado. Não tem acesso a nada. Não tinha acesso à cultura, não tinha acesso à saúde, não tinha acesso a nada. Melhorou um pouquinho. Eu acho que melhorou, sabe, Gustavo.

E outra coisa assim, a questão da moradia. Porque a gente fazia os mutirões. Começou com os mutirões. O pessoal se organizava, se inscrevia, fazia filas, e o mutirão era assim ó: eles davam o material, e cada um ia construir a casa do outro, o outro ia construir a casa do outro, e um ajudando o outro. É o sistema do mutirão. Aí, se queria fazer uma praça, a prefeitura vinha com o material e os moradores construíam a sua praça. E a gente trabalhou muito em cima disso, da questão de os próprios moradores ganharem o material e eles fazerem. "Quero uma praça aqui", e fazer uma praça aqui. Enfim, ajudar. É uma forma também de estar ajudando.

Essa Praça José Bento que tem, é por conta do José Bento* das CEBs. Quando eu entrei nas CEBs, ele já estava. Ele era muito batalhador, o seu José Bento e a família dele 
inteirinha. Eu trabalhei muito com eles, muito. Ele era uma pessoa que tinha uma cabeça muito aberta, muito boa, o seu José Bento. E quando entrei para as CEBs, ele já estava lá.

E aí eu fui designada para ir à Romaria da Terra. Sabe que, daqui de Santo André, mais a Diocese, acho que foram umas 5 pessoas da minha região para a Romaria da Terra. Escolhem pessoas da região. Só que você tem que bancar tudo. Transporte, tudo, mas você vai para representar a Diocese. E eu fui escolhida, a Ilda, a dona Lígia* - aquela mulher que estava aqui - e umas outras. Nós ficamos em Penápolis. Dormimos em um colégio das freiras em Penápolis, depois nós fomos para Promissão. A Romaria da Terra. Ai, Gustavo, de Promissão, ir até a agrovila de Penápolis, 4 quilômetros a pé! Vinte mil pessoas! Nossa! A coisa mais linda! Você ver assim... um monte! Você dava uma olhada para trás, parecia que o povo não tinha saído de Promissão ainda. Nossa! MUITO LINDA! Sabe o que é vinte mil pessoas!?! Vieram de todas as partes do país. Nossa! Muito legal mesmo. Lá estava o padre Dom Paulo Evaristo*, estava o Hélio Bicudo*, estava aquele Plínio de Arruda*... que foi candidato a presidente. Vários políticos estavam lá. Depois que terminou, a gente pegou o ônibus e veio direto para São Paulo. Mas foi uma experiência GRATIFICANTE!

Acho que foi em 82, 83, a Romaria da Terra. Foi um momento MUITO forte, em que as CEBs estavam MUITO atuantes. Que, realmente, havia uma necessidade muito grande de liberdade, de expressão, sabe. De construção mesmo.

$\mathrm{Eu}$ acho que foi uma experiência muito rica, porque você aprende muito com as pessoas. $\mathrm{Na}$ verdade, o aprendizado é para você, sabe. Você não vai ensinar nada, você aprende com as pessoas. Porque são pessoas simples. São pessoas humildes. Mas você olha a pessoa assim e ela tem uma... uma cultura, uma dimensão de Deus muito grande, sabe. Ela tem uma cultura assim... uma visão social muito grande. E essas coisas você não aprende no banco das escolas. Você aprende com a vida. É vivenciando essa vida que você aprende. Você não aprende se você não vivenciar. Você pode ter a teoria na sua cabeça, mas a vivência é mais gratificante. Você viver é mais gratificante. Você estar no meio deles, assim... É cansativo, mas é muito gratificante. Eu acho que valeu a pena. Hoje eu não participo, só vou na missa. Não participo. Isso porque eu estou com quase 66 anos, né.

Eu estou meio cansada. E eu acho que eu não tenho tanto essas virtudes que precisa ter. Porque você tem que ter... se doar, é um sacerdócio. As CEBs eram um sacerdócio.

O nosso grupo era daqui da rua. Era um grupo que, naquela época, a gente conseguiu organizar mulheres com quem se podia contar para trabalhar. Dezoito. Era um grupo grande. Nenhum grupo tinha dezoito mulheres firmes, assim: "Mulheres, vamos fazer isso?". "Vamos". Ajudar a organizar outras mulheres, por exemplo, para decidir onde deviam ficar mais policiais no tancão. Ou qualquer outra solução para o tancão. Você conseguia reunir aquele povo e levava para a Câmara, para discutir. Para falar, para reivindicar. Você vê, por exemplo, a gente trabalhou com atletismo. Para tirar esses jovens da rua, a gente montou atletismo na escola. Fizemos uma oficina na escola. E a gente, naquela época, reuniu acho que uns cem jovens. Naquela época era muito. A fase áurea. Tinha bastante atuação dentro das escolas. Muitos professores nos ajudaram. Só para você imaginar, o ônibus do SESI vinha pegar os jovens aqui na escola! Olha que oportunidade para os jovens.

Gustavo, sabe que a gente fazia reuniões com os pais. Que coisa linda, né, Roberto? Tinha mais de cem pais. Era muuuuuito legal. De pais do atletismo.

Naquela época, acho que na rua tinha uns vinte jovens. Tinha muita criança naquela época. Então, a gente conseguiu levar todos aqueles jovens da nossa rua, e de outras que quiseram participar, para a escola, para o atletismo. Aí, eles iam viajar, tinha um ônibus, tinha acompanhante, professor. Alguns pais iam junto para ajudar os jovens. Eles tinham entre 10, 12 anos. Eles ganhavam alimentação. E tudo assim, tudo bonitinho, tudo arrumadinho, não tinha nada assim... E a gente conseguiu para esses jovens que iam viajar para fora do país - 
para o Sulamericano - médico que orientava, na questão ginecológica, na questão do jovem mesmo. Ele ia na escola e fazia reunião com os jovens, e orientava nas questões. Aí, nós tínhamos a psicóloga do posto, que vinha fazer trabalho com os jovens - todos os jovens da escola - sobre orientação sexual, doenças sexualmente transmissíveis, essas coisas. Naquela época. Nós tínhamos uma assistente social, que vinha para fazer a reunião com as mães. Depois tinha também um advogado, que hoje é o Salles*. Ele tinha um escritorinho aqui, quando começou.

Naquele tempo estava começando a trabalhar o Estatuto da Criança e do Adolescente. Estava explicando para os pais o que era o Estatuto, para quê servia. Aí, a gente começou a trabalhar a questão do Estatuto nessa época. Foi quando a gente começou a reunir todas as favelas, os orientadores de cada favela. E a gente trabalhou muito com a irmã Rosina*, que até a creche leva o nome dela hoje. Com a Ilda, com a irmã Lúcia*, com a Rosana, que era assistente social de Santo André, e os jovens que trabalhavam com crianças de rua. Muitos jovens, muita gente participando. Para aprovar o Estatuto. Nós fizemos essas reuniões para aprovar o Estatuto. Aí, depois, fizemos uma passeata na Avenida Paulista.

Acho que tinha 5 mil crianças.

Depois nós fizemos montagem num circo que estava em Santo André. O teatro foi sobre o Estatuto da Criança. Foi muito legal, encheu, você precisava ver. ENCHEU de gente. ENCHEU de crianças. Para aprovar o Estatuto. Porque o Estatuto é uma coisa boa. Só que ele não é empregado. O Estatuto, se você for ver ele ao pé da letra, seria maravilhoso, se eles realmente empregassem o Estatuto. O Estatuto o que é? É tirar criança da rua, devolver para os pais. Mas os pais precisam de assistência psicológica, assistência médica, assistência de tudo. Ninguém vai fazer isso. É muita criança, entendeu. Então, esse Estatuto, o que faz? O pai não tem condição de acolher aquela criança, ele volta para a rua. Porque eles não vão cuidar do Estatuto como ele deveria. Porque no Estatuto, ele é muito lindo, sabe.

O que os caras do Estatuto têm que fazer? Têm que se reunir com os pais das crianças, têm que dar assistência social, dar um monte de coisas. Não fazem. Tanto é que o governo agora está repassando a verba para as entidades. Não é mais a prefeitura que fica encarregada. Então, ele fugiu do ideal. Da proteção, da criança ter direito à educação, ter direito à saúde, ter direito à alimentação, direito à creche. Isto está na Constituição. Então, eu acho que é uma coisa que fugiu. E a gente batalhou muito para sair isso aí. A gente batalhou muito também para fundar o Hospital de Clínicas. A gente ficou dias e dias, até meia noite, até uma hora da manhã nos reunindo, com o pessoal, com o secretário da saúde de São Paulo, que era o Pinotti naquela época.

A gente se reuniu muitas vezes com ele. Todo o pessoal da Zona Leste de São Paulo se reunia - o pessoal da saúde -, para conseguir verbas, para melhorar a saúde. É a Pastoral da Saúde. Está em todas as igrejas, em todas as comunidades. Então, a gente se reunia num grupo grande para reivindicar. Todas as paróquias de Santo André, todas assim, os líderes de cada entidade, por exemplo, sindicato, qualquer que estivesse engajado nesse ideal, se unia junto.

A Maria José, naquela época, era enfermeira aqui deste posto, do Centreville. Na gestão do João Avamileno* ela entrou como... acho que chefe de... negócio de saúde lá, era um cargo bom da área da saúde. Então, ela visitava os postos, as comunidades, para ver onde estavam as necessidades, o que precisava. E ela orientava os postos de saúde. E trazia cursos para os postos, para orientar adolescentes, a mãe gestante, o idoso, a idosa, a mulher idosa. Ela trazia muita coisa para os pais. Enfim, através dela a gente conseguiu ter acesso a muitas coisas. E os adolescentes tinham uma assistência muito grande nos postos. O drogado, a grávida. Tinha muita orientação. Sempre tinha orientação nos postos de saúde, às vezes nas creches, nessas escolinhas da prefeitura, nesses lugares. E sempre tinha trabalho para idosos, na menopausa. Na depressão pós-menopausa, que as mulheres têm. Tudo questão da área de 
saúde que envolve idoso. E para as crianças a gente batalhou sempre na vacinação, nas campanhas, de conversar com as mães, de orientar as mães, para levar as crianças, para vacinar e tudo. Esse é um trabalho muito bom. E um trabalho voluntário.

E a questão do Hospital de Clínicas, a gente conseguiu uma verba de 28 milhões naquela época. Era um dinheiro como se fosse milhões de reais naquela época. Mas aí, sabe o que aconteceu? A gente conseguiu essa verba, mas mudou a gestão - eu acho que foi o Brandão* que entrou depois - e a verba não sei onde foi parar, não. Sumiu. A gente conseguiu a verba, aí... sei lá... ninguém viu. Aí continuou essa... Depois que entrou de novo a outra gestão é que a gente conseguiu. A gente conseguiu a verba para fazer o Hospital de Clínicas. Começou a funcionar, que é o Mário Covas. Nosso Mário Covas.

Aí, depois, a gente foi atuar no campo da Educação. Fomos tudo para a Educação. Aí, a gente fazia aqueles fóruns. Você chegou a ver o Fórum da Educação de Santo André? Reunia várias escolas, várias entidades ligadas à área de Educação, Cultura e Lazer. A gente se reunia em Santo André, lá no prédio da Assistência Social. Aí, a gente fazia várias reuniões. Nós formamos o EJA - Escola de Educação de Jovens e Adultos. O EJA, a metodologia dele é mais baseada na Emília Ferreiro*. Você chegou a ver alguns tópicos dela, né? Que é argentina. A gente começou a estudar, voltar a estudar o método dela para formar os EJAs. E também do Paulo Freire*, que é o método "Ver, Julgar e Agir". A gente fez vários cursos ali naquele Instituto Sedes Sapientiae, em São Paulo. Fizemos curso de formação lá. Aí, nós montamos os primeiros EJAs.

Aqui na São Geraldo montamos duas classes de EJA. Tinha o monitor e tinha o ajudante. Na classe tinha 30 alunos. Aí, precisou de duas classes, e tinha 50 alunos. Então, foi um momento em que a gente começou a trazer para as comunidades a Escola de Jovens e Adultos, baseados no Paulo Freire, na Emília Ferreiro. A gente fez um ajuntamento dessas coisas e a gente bolou o estudo. Que é para a pessoa aprender... Porque o adulto, principalmente o idoso, vive a vida inteira sem saber ler e escrever, mas, ele tem tudo aqui, na cabeça, ele sabe tudo, só que na hora de passar para o papel ele não sabe. A dificuldade do adulto é mais essa daí. Então, com esses métodos, a gente tentava levar para eles essa facilidade de colocar o saber deles na escrita, no papel. E a gente trabalhou uns 4 anos aí.

Depois, mudou a gestão e veio o MOVA. Quando o Filippi* ganhou em Diadema, copiaram o MOVA de lá e trouxeram para cá, que também era movimento de jovens e adultos. Só que não era subsidiado pela prefeitura, era mais por voluntários. Agora, nessa última gestão, é que eles estavam dando uma bolsa de estudos para quem era o monitor.

Mas, foi assim, uma questão de uma mudança muito grande, eu acho que foi uma abertura... na minha vida foi uma abertura muito grande. E eu tenho que agradecer muito ao Roberto, porque ele me ajudou muito. Ele colaborava comigo, participava junto. Ele ficava com as crianças para que eu pudesse participar. E as minhas filhas também. As minhas filhas, onde eu estava elas estavam junto, fazendo pesquisa, fazendo festa junina, ajudando na comunidade. Elas estavam junto, fazendo os trabalhos na comunidade.

\section{ROBERTO}

Ela estava fazendo um serviço bom, um serviço em benefício do bem comum, do bem geral. E se sente feliz trabalhando assim. Por que não participar, não ajudar? Tem que estar ajudando. Ajudou a Igreja, ajudou os movimentos de rua aí, ajudou as pessoas. Que bom, né.

Mas ela nunca teve interesse político, viu. Ela sempre teve capacidade de liderança, assim, de captar as pessoas, amizades, mas ela nunca teve objetivo político, objetivo eleitoreiro, de "ah, vou ser isso, vou ser aquilo". Ela sempre fez de coração, como cristã. Então, isso vem da JOC, vem da Igreja. É Jesus Cristo dentro do coração da pessoa, quer dizer, ela fez o bem pelo bem, ela não fez o bem com interesse. "Olha, eu vou fazer, 
futuramente eu vou ser candidata, posso ser uma vereadora, posso ser uma deputada". Sem isso. Ela fez com interesse realmente de ajudar. Se existissem pessoas como ela, assim, que realmente lutassem com esse objetivo, nossa sociedade estaria bem melhor.

\section{MESSIAS}

Mas, eu acho que essa questão, é questão que está dentro de cada um. Eu posso gostar de fazer essas coisas. Mas tem gente que não gosta de fazer isso, de se doar, de estar indo atrás. Porque você dá a cara pra bater. Dá trabalho. Tem gente que diz, por exemplo: "Você trabalha para o PT".

Eu digo assim: "Não, eu trabalho para a Igreja. O PT é que se aproxima da ideias cristãs”. Naquela época. Agora rachou muito. Mas naquela época era assim.

Tinha um núcleo do PT aqui. Guaraciaba, naquela época, não tinha, mas, tinha aqui, depois que a Tina foi candidata. Ela fez um núcleo dela aqui. Mas aqui no Guaraciaba não tinha. O núcleo do PT era em Santo André mesmo. Tinha até aquela escolinha de política do Celso Daniel, que tinha fundado para jovens que quisessem participar da política. Tinha uma escola de formação política. E muitos cursos eram feitos na central da CUT de Santo André. A CUT emprestava o prédio e a gente fazia muuuitas reuniões. E a gente também fazia reuniões com as mulheres.

A situação das mulheres, naquela época... dos anos 60 para cá, houve uma abertura muito grande. As mulheres começaram a mudar suas cabeças, a ter uma postura diferente. De sair de casa, de poder estudar, de poder trabalhar, de poder não pensar só em ficar dentro de casa. Elas começaram a ter essas aberturas. Então, a gente fazia muitas reuniões com as mulheres. Não para abandonar o lar, mas para ter essas ideias de que ela podia fazer outras coisas que não ficar só dentro de casa. Daí, a gente batalhou muito. Tinha muita reunião, em Santo André, para essas mulheres fazerem parte desse grupo. Era a 'Fé Menina'.

$\mathrm{Eu}$ acho que até hoje ainda tem, só que tem muito desse grupo na Metodista. A pastora Haidi*... Ela celebrou muitas missas junto com o padre Mahon, até por essa questão: a Haidi é uma pastora..., nossa, tem tanta coisa... Conforme eu for falando eu vou lembrando.

Ela era da Igreja Metodista. Ela era pastora. E a gente ia muito na Metodista. Lá se reuniam várias mulheres, de vários grupos sociais, para trabalhar essa questão da mulher: de trabalhar, desses movimentos de querer poder ganhar seu dinheiro fora também. Poder ter um trabalho fora para que não seja só ser dona de casa. Então, a gente trabalhava muito essa questão de ter uma visão assim diferente. Dessa abertura das mulheres. E a Haidi ajudou muito a gente.

Ela participava da 'Fé Menina'. Na Metodista, eles têm uma cabeça muito aberta, muito boa para essas questões sociais. Eles são muito legais, sabe. E a Haidi ajudava a gente. Ela organizava a gente.

Esse grupo 'Fé Menina' era assim: eles convidavam mais as mulheres que atuavam nos bairros, por questão das CEBs, por questão da Igreja, da ACO, alguém que estava ligado a algum movimento. Por exemplo, se era das CEBs eles convidavam, assim, quem tinha uma certa liderança. Então, eles convidavam as pessoas dos movimentos. Algumas pessoas.

Quem organizava era geralmente o pessoal da Metodista, a Haidi, era a Tina - que participava da ADC, a Associação das Donas de Casa -, e tinha outras mulheres que eu não lembro mais... A Maria José, que fazia parte... Tinha muitas mulheres lá... A Márcia, assistente social. Todo esse pessoal participava, todas essas mulheres. E podia levar outras mulheres junto com a gente. Então, era assim: cada bairro, eles levavam as lideranças. Por que esse hábito? Para as mulheres ajudarem a trabalhar essas questões na rua, com as mulheres com quem a gente precisava trabalhar. Daí que surge o movimento da creche, de ajudar essas mães a saírem de casa, até para ter mais dignidade. 
As mulheres eram muito sofridas, muito maltratadas mesmo. Então, era uma questão de libertação da mulher. Para nós era essa questão: da libertação da mulher. A mulher como um rosto, como um ser humano. Porque atrás da mulher, não é mulher, é ser humano. Não é uma coisa abjeta, que você é usado, é maltratado. Então, é para dar uma certa dignidade.

Os homens não vêem a mulher muito bem, igual aos homens. E as mulheres também. Não sei a questão de por quê. Eu não sei. Eu morava naquela rua e eu saía muito para participar quando tinha as formações do Clodovis Boff, de Teologia da Libertação. Eu deixava muito a minha casa naquela época. E quem tomava conta era ele. As crianças eram todas pequenininhas. Ele ficava com as crianças, ele cozinhava, ele ficava tomando conta. E, muitas vezes, as mulheres sentavam em frente à minha casa e ficavam falando mal de mim, falando que eu não prestava, que eu saía por aí, que ele era bobo, porque nem sabia o que eu estava fazendo por aí. "Olha que homem tonto. Fica tomando conta das crianças e a mulher sai o dia inteiro...". Sabe, isso tinha bastante. A questão até das mulheres me maltratarem na rua mesmo, sabe, porque, às vezes eu deixava as crianças e ia dar catequese, a participação da mulher na comunidade...

Então, tinha umas que falavam que eu saía, que eu já ia pra debaixo da saia do padre. Ai, falavam cada coisa horrorosa! Nossa Senhora... Às vezes, dava vontade de desistir. Tinha gente que pegava pesado. Tinha cara que ficava bêbado e ia lá no meu portão me ofender. Falava um monte. Um monte de merda, um monte de coisa ruim. Me maltratava muito. Mas, graças a Deus, eu superei tudo isso. Porque eu tinha o apoio dele [refere-se ao Roberto]. Se ele não me apoiasse, aí ia ser difícil. Mas eu tinha apoio dele. Então, ficou mais fácil.

Eu não respondia a quem me maltratava. Porque eu penso assim: é questão do entendimento. Eu gostava do que eu fazia e o que eu fazia não era uma coisa ruim. Eu não estava prejudicando ninguém. Muito pelo contrário, eu estava ajudando as pessoas. Mas, naquela época, não tinha mulheres que faziam isso. Acho que fui uma das primeiras. Era uma ou outra mulher que se reunia na Igreja no ABC. Ou que se reunia para organizar as coisas.

Depois, me chamavam de "mãe da rua", porque achavam que eu... Aí, me apelidaram de 'mãe da rua', e eu não gostei. (risos) Acho que era um tanto pejorativo, 'mãe da rua'. Porque, além de eu fazer tudo isso, eu cuidava das crianças da rua. Eu organizava gincanas, eu ia para o Paço, na primeira gestão do Celso Daniel, tinha muita atividade. Fazer pipa... tinha muita coisa para os jovens e para crianças. Eu catava eles e levava para o Paço, levava para o cinema, sabe. Aonde eu ia, estava aquela criançada tudo junto. Aí, se eu ia para a natação, eu procurava ver as crianças que podiam participar. Eu levava todo mundo para a natação. Na rua, todas as crianças participavam. Então, me chamavam de 'mãe da rua'.

$\mathrm{Na}$ nossa casa, para você ter uma ideia, tinha dias que você contava 14 casinhas. Ou então, as meninas chegavam da escola, eu tinha várias lousas grandes, comprava giz e elas ficavam brincando de escolinha. Você sabe que elas aprenderam muito mais brincando do que na escola? Porque na brincadeira de escolinha, a minha filha mais nova, de 5 anos, aprendeu. Ela foi alfabetizada sem ir para a escola. Quando ela chegou na escola, já sabia a cartilha de fio a pavio. Na brincadeira. Brincando de escolinha.

Então, era uma coisa boa. O pessoal não podia me questionar. Eu acho que, talvez, elas não pudessem, talvez elas não tivessem essa liberdade que eu tinha, esse apoio que eu tinha... então, talvez por causa disso elas me questionavam, me criticavam. Mas, depois, eu não ligava, não. Nem dava bola. E também não ligava para cara feia, não. Depois, eu organizava, sentava com elas, eu conversava com elas porque que eu saía, o que eu ia fazer.

Porque, às vezes, tinha encontro que eu não podia levar todo mundo, era restrito, fechado, só para lideranças mesmo. Mas, quando podia, sempre que podia, dava uma abertura, eu levava muitas pessoas. Comecei a levar, levar, levar, e aí acabaram os problemas. Quando elas começaram a participar, começaram a gostar, acabaram os problemas. 
Você tinha que levar eles para participarem com você. Não adianta só eu ir lá. Eu não faço nada sozinha. Eu tenho que carregar esse povo comigo. Se eu não carregar eles comigo, não adianta. Não vai resolver o problema. CEBs não se faz sozinho. Nada você faz sozinho. Você tem que ter um povo atrás, um povo junto. Movimento é assim: faz junto. Então eu comecei levar elas. O Grupo de Rua tinha 18 pessoas que atuavam na escola, atuavam nas reivindicações. Se eu não podia a outra ia...

Fortalece muito a amizade. Porque você interage com vários grupos, várias pessoas e vários movimentos. Você conhece muita gente, conhece muitos políticos também, que vão lá no meio. E acho que amplia muito sua visão de amizade. Eu acho que 'amigo-amigo', você não tem, sabe. Dá para contar nos dedos seus amigos, que você pode se abrir, falar. Mas você tem muita amizade. E a nossa amizade era tão boa que, por exemplo, se alguém estava doente a gente ia ajudar a pessoa, limpar uma casa para ela. Se outro estava com problema, a gente se reunia e ia lá ajudar. Se estava desempregado, a gente ia ver a necessidade dele, o que ele estava necessitando naquela casa. Se outro ia procurar serviço, às vezes não tinha dinheiro para o transporte, e a gente dava dinheiro para o vale-transporte. Então, era assim, o grupo, a gente atuava nesse campo, no campo da fé. Mas esse Deus tem que caminhar junto. Se for só política, não caminha. Porque aí começa a dividir as pessoas. As pessoas trabalharem em cima do Evangelho você consegue. Tudo tem que ser à luz do Evangelho. Tem que refletir o Evangelho, ver a necessidade do povo, e em cima dele você caminhar.

Só com a política você não consegue. Porque eu posso gostar do PT, mas tem gente que não gosta, gosta de outro partido. Então, você não vai conseguir trabalhar. Mas, se pegar o Evangelho, em cima da luz do Evangelho, você refletir, você consegue.

No PT eu não trabalhei. Eu nunca fui petista. Eu sempre ajudei naquilo que eu achava que ia ser bom para todo mundo. Porque o PT tinha uma proposta muito boa voltada para o social. Na época da gente, acompanhamos muito as propostas deles e eram propostas viáveis. E a gente estava precisando de um governante assim. A gente apoiou. Mas eu não sou petista, quer dizer, não sou filiada ao PT. Mas eu gosto das ideias dele. Gostava muito. Por conta de que tinha uma população mais pobre, mas que tinha mais acesso às coisas.

Para fazer qualquer coisa, você teria que conversar com o pároco, porque você não vai fazer nada sem ele. Porque ele é que comanda a comunidade. E sempre utilizar o espaço da Igreja para poder passar alguma coisa. Assim, a gente usava a comunidade mais para passar propostas mesmo. Mas as propostas eram boas, não eram ruins. Mas tinha que consultar o padre. Aí, a gente falava: "Olha padre, está acontecendo isso, isso e isso". Porque nos procuram. Procuram as lideranças para passar as propostas. Aí, a gente falava com o padre, e se o padre autorizava, tudo bem.

$\mathrm{Eu}$ acho que o que foi marcante dos padres foi esse apoio que eles deram para a comunidade. E essa abertura. Porque a comunidade não tinha essa abertura. Não tinha esse espaço. Eu acho que o bom desses padres foi que eles nos deram essa abertura. Antes, você tinha os problemas, mas você não tinha apoio de ninguém. Nem o padre te apoiava. Você tem os problemas de falta de água, falta de luz, conta de luz, disso, daquilo, mas, era uma comunidade carente, muito pobre. Mas você não tem onde pedir ajuda. Então, esses padres, eles deram essa abertura para a gente. O padre Mahon, o padre Pedro* - que hoje mora na França -, o padre Carlos* - que já se aposentou, que era um espanhol, e está velhinho já. Aqui em Santo André tinha muitos padres que nos davam esse apoio, que ajudaram, que acompanharam a gente nessa trajetória. Eles nos davam esse apoio, nos davam esse espaço da comunidade. E traziam a formação da fé, fé cristã. Fé e política. Nunca a política depois da fé. 
Não. Fé e política. Davam essa formação para a gente. Então, você saía da formação com uma visão muito legal de como trabalhar essas situações de uma forma cristã, de uma forma dentro da fé, sem sair fora, senão você não consegue trabalhar.

Então, essa abertura que eles deram eu acho que foi marcante para essa mudança. Se não fosse assim, não teria. Tudo isso começou a partir da ditadura militar, que eles começaram a vir para o Brasil, e a partir das Comunidades Eclesiais de Base, quando foram criadas. E tinha também a pastoral operária, a PO, que trabalhou muito dentro das fábricas, na questão da evangelização dentro das fábricas. Mas não essa evangelização de só rezar, esse Deus muito só teórico, lá nas alturas, e sim esse Deus no meio do povo.

Então, essa parte que eles deram muito, ajudou bastante. Quer dizer, quem tinha já essa visão, cresceu. Ampliou a visão. Quem já tinha essa visão, olhava e já via. Mas, como você vai trabalhar essa questão? Você não vai trabalhar sozinho, você não consegue. $\mathrm{O}$ governo era diferente, era o oposto, também não ia te atender. E naquela época, a repressão era muito grande, porque qualquer coisa que você fosse fazer fora, no regime militar, você era massacrado. Quantas vezes esse padre Mahon apanhou lá dos militares. Bateram nele... Quantas vezes a gente foi..., a gente fugiu, a gente estava numa reunião, a polícia chegava e prendia ele. Ele ia para a cadeia também. Ele ficava numa cela lá, mas ele apanhava também. Apanhou junto com o povo. Então, para você ver: é coisa ruim? Não é coisa ruim, é coisa boa. Para a gente. Para o preso não é coisa boa.

Nós queríamos parar os ônibus, até para a questão de conseguir essa assinatura... essa mudança de não ser mais as empresas a subsidiarem e sim a prefeitura. E nós fizemos uma... quem era do sindicato estava fazendo..., assim, era todo mundo junto. Pararam os ônibus, mas só que tinha os fura-greve. Então, a gente ajudou muito a parar esses ônibus, de uma forma não muito legal. (risos) A gente levantava muito cedo mesmo, quando os ônibus começavam a trabalhar, para eles não saírem da garagem.

Eu não participei das greves. A única coisa que eu participei muito foi do fundo de greve. O fundo de greve era um fundo que a gente mantinha. É um banco, banco de alimentação para manter, para dar sustentação a quem estava na greve, para eles não desistirem da greve, e não desistirem de lutar, e não faltar comida para eles. Porque se falta comida, ele vai voltar a trabalhar. Então, para ele não desistir de lutar, tinha um fundo de greve. Eu trabalhei na Feira da Cultura Operária. A gente fez, e várias entidades, no Duque de Caxias, a Feira da Cultura Operária. Então, cada entidade vendeu algumas coisas para arrecadar fundos para o fundo de greve. E a gente mantinha as greves através do fundo.

Nós vendemos suco, bolinhos de frios. E a minha especialidade era suco. Eu fazia suco. Suco de abacaxi, suco... mas tudo natural. Eu fiz suco na nossa barraca. As mulheres da rua foram para a minha barraca, trabalhar comigo. Quer dizer, cada Grupo de Rua, e cada entidade, cada bairro, fez a sua barraca. Cada um vendia uma coisa. A gente instalou tudo direitinho. Eu levei liquidificador, tudo, e fazia suco lá na hora. Levamos frutas. Era um calor danado, né, então tomava tudo. A minha especialidade era sucos e frios, bolinhos que as mulheres faziam. A gente levava os bolinhos, tudo, e vendia. E esse dinheiro que a gente arrecadou foi para o fundo de greve. A Feira da Cultura Operária.

Foi na época das greves. Nessa última greve que houve, foi uma greve bem forte, que a Volks parou. Não lembro mais o ano... Acho que foi em 79. Foi quando o Lula* estava na liderança. Foi mais ou menos nessa época que a gente fez. Para manter a greve tinha que ter fundo, senão o trabalhador desistia. Porque ia passar fome, voltava correndo, largava a greve. Porque a família começa a passar fome e aí ele não ia querer. E foi aí que a gente conseguiu manter aquela greve, grande. Foi aquela greve BEM GRANDE. Foi assim que a gente 
conseguiu manter ela, através do fundo de greve. Eu trabalhei muito no fundo de greve. Sem comida você não vai fazer luta.

Igual hoje, o emprego: o emprego ficou escasso. Por quê? Porque as fábricas foram embora praticamente. Globalizaram tudo. Mas globalizaram o quê? A miséria, o desemprego. Então, hoje não dá para você fazer greve. Porque se você faz greve hoje, se não quer trabalhar, você olha para trás e tem milhões que querem a sua vaga. Então, ninguém faz greve hoje. Então, greve hoje, não sei como poderia... Através da organização. Eu acho que a sociedade vai ter que voltar a se organizar e começar a cobrar de novo. Mudar. Mudar para melhor a escola. Eu acho que uma coisa que precisava fazer com urgência é o ensino público. Precisaria mudar. Porque as nossas crianças estão perdendo muito com isso daí. A sociedade voltar a se organizar.

A gente queria um partido que viesse mais no anseio. A gente esperava muito do partido. A comunidade, o povo esperava muito. Achavam que o partido ia resolver todos os problemas, que a vida do povo ia melhorar. Era um sonho. Quando o Lula entrou, era uma estrela, era um sonho. Que tudo ia melhorar. Mas aí, a gente vê que entre eles não existe essa conformidade. E mesmo a Igreja, depois que o PT entrou, o povo se acomodou. Porque eles não deixaram os movimentos participarem com eles. Eles cortaram. Depois, eles barraram os movimentos sociais. Nos primeiros meses, no primeiro ano, eles deixaram os movimentos participarem junto. Depois, eles barraram, não deixaram mais a gente participar com eles. E a base ficou parada. Aí, a base parou e cada um foi para um canto. Um foi pra cá, outro aqui, e quem não conseguiu nada no governo...

A base foi jogada de lado, sim. A base não foi chamada a participar. Depois tinha aqueles orçamentos participativos. Um ou outro participava. Eu fui umas duas vezes, mas depois não fui mais, não. Eu deixei de participar porque ele ficou doente também, né. Ele teve que fazer uma cirurgia, ficou 6 meses parado. E tinha uma filha que desmaiava muito e eu também não podia abandonar; e a minha mãe veio morar para cá, ela teve uma perna amputada. E aí eu fiquei muito amarrada. Aí, não participei mais. Mas senti muito, mesmo que esse padre Félix*, que está aí hoje... o Mahon tem vontade de atuar, mas o Mahon já está só. Então, a comunidade está aí parada. Está aquele grupo dentro da comunidade que apóia o padre, o padre que está aí, que é o vigário. O Mahon não consegue muita coisa, primeiro porque está só. Então... e eles não têm essa ideia, sabe. Para ter essa ideia tem que ter liderança, tem que ter alguém que tenha essa ideia. E cobrar do padre abertura, e brigar de novo como a gente fez antes, brigar para o padre deixar fazer uma reunião de JOC. A gente brigava com os padres para poder fazer: "Olha, nós vamos fazer uma reunião de JOC". O padre não deixava.

Tinha padre que não deixava. As coisas não eram assim. Era um ou outro padre que deixava. Aquele padre do meu bairro - o Parque Novo Oratório - não deixava a gente fazer. A gente tinha que fazer reunião fora da igreja! Ele emprestava só o pátio da Igreja. Dentro da igreja não deixava, não. Porque cada um tem uma linha.

Eu acho que o maior problema é esse: eu vim da roça com uma mão na frente e outra atrás. Você tinha que trabalhar para sustentar seu pai, sua mãe e seus irmãos. Se você quisesse comer, você tinha que trabalhar. Então, você tem aquela visão de vencer na vida, você é impulsionado, você é obrigado, existe assim uma coisa que impele você a querer essa mudança. Ir para a frente. Ou você trabalha para comer ou você morre de fome. Ou então, você se prostitui, porque assédio não falta. Hoje, os nossos jovens não têm essa coisa. Eles têm tudo. Tudo pronto. Então, eles não têm para quê lutar.

Eu acho assim, Gustavo: também vai da necessidade. 


\section{ROBERTO}

$\mathrm{Eu}$ acho que hoje o individualismo vai favorecer as classes dominantes. Pode ver na televisão: tudo é o personalismo, é o individualismo, e justamente isso mata todos esses movimentos que vocês estão falando.

\section{MESSIAS}

Mas, também, era uma época assim: o bairro não tinha nada, não tinha água, não tinha creche, não tinha organização, não tinha nada. Então, havia uma necessidade, entendeu. Eu acho que hoje as necessidades existem, mas são diferentes de quando eu vim para cá. As necessidades são outras. Precisa melhorar a escola pública? Precisa. Precisa melhorar a saúde? Precisa. O que precisa? A sociedade precisa de muitas coisas. Acesso a muitas coisas. Mas, hoje, os nossos jovens, até os mais pobres têm acesso. Eles podem ir ao cinema, eles podem ir ao teatro. Se ele quiser, ele tem lazer, tem tudo para ele.

Pobre não tinha nada. E a gente tinha que trabalhar, estudar, tinha que estudar muito para poder ganhar dinheiro pra pagar aluguel, pôr comida em casa. Não eram eles que davam. A gente é que tinha que dar comida para eles. Então, a necessidade era outra. Diferente dos jovens de hoje. Esses jovens, eles não precisam buscar quase que nada, está tudo pronto. Então, eu não sei, talvez por isso é que está assim. Eu não sei qual é a solução... a gente não tem assim... talvez tenha que sentar, a sociedade tenha que sentar para poder descobrir alguma solução.

Eu estava na Praça do Carmo. A gente estava fazendo o $1^{\circ}$ de Maio na Praça do Carmo. Tinha muita gente reunida. Teve uma missa na praça e o pessoal da JOC estava tudo em peso. Aí, tinha muitas pessoas disfarçadas, gravando, tirando foto. Como eu falei para você, tem os olheiros que ficam lá: se viam foto, tirando foto, gravando, aí eles destruíam a máquina mesmo. Porque tudo aquilo ia se voltar contra você. Aí, estava o Geraldo Vandré*, estava o Trio Marayá*, o padre Mahon, tinha vários outros padres celebrando essa missa na Praça do Carmo. De repente... o pelotão de choque apareceu... Mas foi uma correria! O padre Mahon correu para a casa do bispo e nós corremos atrás do padre, o Geraldo Vandré e o Trio Marayá, tudo para a casa do bispo. Era o Dom Jorge* naquela época. Nós ficamos um tempo lá. E o pessoal dispersou.

Naquele dia eu não fiquei sabendo quem eles pegaram. Mas foi uma correria danada, viu. Nós ficamos bem umas 3 horas na casa do bispo. Até a polícia ir embora e a gente ir para casa. Lá na casa do bispo eles não entraram. Até que eles respeitavam, viu. Naquela época eles respeitavam. Hoje eu sei lá.

Lá nós ficamos conversando. Eu tinha até há pouco tempo autógrafo do Geraldo Vandré. Ele estava cantando aquelas músicas que ele cantava, do festival. Naquele tempo, tinha os festivais. E aí ele estava cantando aquelas músicas e apareceu. E aí, foi uma quebração de máquina de gravação!, uma paulera! Quando nós olhamos - eu e minha amiga -, vimos o padre correndo para a casa do bispo, nós falamos: "Ah, é pra lá que nós vamos". (risos) Não vou apanhar, nada. Tá louco! Dói pra caramba. (risos) Eu não gosto de dor. Não suporto dor. Mas os nossos amigos eles pegaram. A gente nunca mais viu a cara deles...

Então, naquela época que eu fazia as festas juninas na rua, eu lembro, a gente fazia rodas de violeiros... sabe. A gente convidava vários violeiros, e faziam rodas de violeiros. E a gente dava uma caixinha para eles. Lá vinham muitos violeiros. Essa roda de violeiros atuava das sete da noite até as onze, mais ou menos, que ia até a meia noite. Das duas da tarde até as cinco, eram só brincadeiras para as crianças. Das cinco da tarde até as sete, eram brincadeiras para os jovens, música, coisas que os jovens gostavam. E das sete em diante era só roda de violeiro, era forró... E o pessoal dançava na rua, era gostoso. Tinha dia que às três horas da 
manhã ainda estava o forrozão lá, o pessoal tudo na rua dançando. O pessoal que vinha de outras ruas. Nossa! A rua lotava de gente, ficava cheio. Nossa! Muito legal.

Eu acho que as lideranças desistiram porque... vai cansando também. As pessoas vão envelhecendo, então elas não têm mais aquele pique que tinha antes. Porque todas essas coisas têm uma mão-de-obra muito grande. Muito trabalho. Depois você tem que limpar tudo o que você sujou. Tem que limpar, tem que devolver materiais, tem que fazer instalação. Muitas pessoas também já morreram. Então, era muito legal.

Eu me lembro da primeira missa que a gente fez na igreja, que nós ensaiamos em casa, e tinha MUITO violeiro. Uma missa muito bonita, aquelas missas sertanejas.

Os meus irmãos todos participavam da JOC. A família praticamente. O meu pai, a minha mãe, todos participavam da JOC. Na rua em que eu morava, praticamente todos os jovens participavam da JOC. Era muito gostoso. Sabe por quê? Nós tínhamos um ambiente sadio. Um ambiente com propostas boas, de vida. Nós tínhamos ideais. Ideais de jovens: estudar, casar, ter filhos. Entendeu? A gente tinha esses sonhos. A gente tinha ideais. Então, o ideal da JOC era um ideal muito sadio. E a gente se reunia muito. A gente ia fazer excursão juntos, fazia bailinhos. Todo o pessoal da JOC ia. Quando fazia os encontrões da JOC, a gente reunia todos os grupos, de vários bairros de Santo André. Tinha até de São Paulo, de Osasco, e vinha tudo junto. A gente se encontra até hoje, tem amizade.

Gustavo, quando eu era criança, que estava na quarta série do primário, eu nunca esqueço. Eu era muito rebelde. Uma vez, a professora do terceiro ano me pegou para botar perto de uma menina que era piolhenta. Estava assim de piolho! E aquelas cadeiras duplas. Assim, você sentava em duas... assim: uma e uma.

Eu disse: "Eu não vou sentar perto dela".

"Você vai sentar, sim, porque eu estou mandando".

"Ninguém quis sentar perto dela, e eu não vou sentar".

Aí, ela falou assim: "Mas você vai sentar".

"Não vou".

"Então você vai lá para a fileira C". A fileira C era dos mais fracos. Tinha A, B e C. Eu estava na fileira A.

"Eu vou, mas não vou sentar perto dela".

Aí, comecei a responder para ela, e ela: "Pra fora. Vai pro corredor".

Eu: "Tá legal". Quando a gente estava no corredor, o corredor era muito legal, sabe. Tudo enceradão, bonitão assim. E olha quem estava do lado de fora: os meus irmãos. Então, o que a gente fazia? A gente ficava brincando de escorregar. Um pegava a mão do outro e ia escorregando. Shhiiiiiiii. As professoras começaram a reclamar. Aí, meu irmão perdeu o equilíbrio e foi com tudo, e bateu na sala do diretor. $\mathrm{O}$ diretor passou, ficou olhando e deu risada. (risos) Ele falou assim: "A sua mãe tem que vir aqui assinar".

"Tá bom". E minha mãe foi assinar. (risos)

Aí assim: "Já para a sala de aula!" (risos)

Não tinha como ficar quieta. Eu acho que já está no sangue. Eu acho que puxei isso muito do meu pai. O meu pai era assim, sabe. Ele tinha pouca leitura, mas ele era muito culto, ele lia muito. E da minha mãe também. A minha mãe é muito inteligente, muito cheia das iniciativas. Ela teve aula sozinha. Eu acho que eles tinham assim uma... passaram boas ideias para a gente.

Eu participava na Igreja. Eu batia o sino da igreja. Era tão legal, Gustavo. Nós éramos bem pobres mesmo. E o padre, ele, nossa!, tinha uma mesa farta de comida, sabe. O café da manhã do padre era uma coisa do outro mundo para a gente que não tinha nada. Aí, a gente combinava, eu e o meu irmão: "Vamos lá bater o sino pro padre?". (risos) Ele disse assim: 
"Vamos". Aí, o meu irmão se pendurava no sino que era menorzinho, que ele era bem magrinho e mais novinho, e eu me pendurava no grandão. E a gente ficava batendo o sino para ele. Depois, ele chamava a gente para tomar café, que era o que a gente queria. (risos)

Ah, mas era MUITO GOSTOSO! A gente comia aqueles bolos, assim. Nossa! Era muito gostoso. Então a gente fazia como quem já era desenvolvido. Já era assim, acho que porque a gente lia muito também. E eu lia muito. Tinha muitas leituras. E participava muito das brincadeiras de rua.

Quando eu ia para casa, a minha patroa sempre me dava uma panela de comida que sobrava, para eu levar para os meus irmãos. Para a minha mãe. Só que antes de eu ir para a casa, eu parava na praça da igreja. Aí, a gente ficava brincando até... Depois catava a minha panelinha de comida e ia para casa.

Porque a gente foi criado assim muito... a gente teve que se criar sozinho. A gente não tinha assim... Nós tínhamos uma formação muito boa, era todo mundo junto. Aquilo que meu pai passou, de fé - foi ele quem passou a fé para a gente -, a educação que ele deu para a gente, isso não se perde nunca mais. Do respeito, da educação, de rezar junto. Todo dia rezava junto. De ele tocar a viola e minha mãe cantar junto, à noite, na fazenda.

Acho que eu não contei essa parte: que os colonos se reuniam no entorno da casa da fazenda, que era lampião de gás, e a gente tinha as lamparinas. Então os peões se reuniam e contavam histórias de bruxas, de... terror. Depois, quem disse que a gente dormia?... Depois que fechava, apagava o lampião de gás, ficava com aquelas lamparininhas acesas, que de manhã você aparecia com o nariz tudo preto. O olho preto, que você respirava querosene. Tudo preto a gente amanhecia. E aquela floresta, você olhava... Nossa! Eu morria de medo! Eu tinha muito medo. Tantos bichos à noite... macaco assobiava... Fazendo barulho. A gente tinha medo na fazenda. Naquele tempo, sim.

Mas eu sempre fui assim... essas ideias de líder, desde de criança. Eu acho que você tem já um... está dentro de você isso aí. Eu sempre lutei a favor de... eu estou sempre do lado de quem está precisando mais. Se é uma criança, se é um cachorro, se é um animal, se é um idoso, se é alguém doente, aí eu estou sempre do lado deste pessoal. Se eu vou numa festa e tem muita gente de classe média assim, eu não me sinto bem, sabe. Eu me sinto bem no meio do povo. Às vezes, a gente vai em algumas festas sociais, mas... os papos são diferentes. São outros papos, que não tem nada a ver com o que a gente imagina e pensa. Então, a gente não se dá bem. Acho que já vem da gente.

Eu nunca imaginei que eu fosse chegar... Quando você vê, você está tão envolvido, e é tão gostoso, sabe. Você se sente tão bem, que você quer se envolver cada vez mais quando é bom.

Não tenho saudade de nada. Eu tenho saudade de uma coisa: da minha juventude. Ela me faz falta. Mas eu não tenho saudade. Acho que eu vivi cada momento, no momento certo. Cada coisa no seu momento. De criança, jovem, de mulher casada - senhora -, CEBs - de ajudar na comunidade de rua -, então eu acho que eu não tenho, não sinto. Eu acho... eu sinto uma coisa boa, uma coisa que eu... de certa forma, eu ajudei a participar.

$\mathrm{Eu}$ ajudei a fazer. Eu ajudei a construir. Eu dei a minha parcela para construir. Eu acho. Mas saudade eu não tenho, não, Gustavo. Eu acho que a gente tem que viver a vida, cada momento que viveu.

Não tenho arrependimento nenhum. Eu acho que foi uma experiência muito grande para mim. Eu tinha necessidade dessa experiência de vida. É uma coisa que a gente conseguiu, assim, através da participação. Eu acho que isso me enriqueceu muito. Eu consegui educar as minhas crianças, educá-las para elas estudarem, para elas não serem... você sabe que quando você vem da base, sem apoio de ninguém, é muito difícil. É muito triste 
você ficar sozinha, não ter aquela base. Você tem a família, que é o teu suporte afetivo, emocional, mas a parte financeira você não tem. Então, como eu via a minha mãe trabalhar muito, e via a realidade de muitas mulheres, que os maridos abandonavam, deixavam sozinhas, cheia de filhos, com casa e comida, e ter que trabalhar para sustentar a família, eu achei que eu não queria isso para elas. Eu queria que elas estudassem e que elas ganhassem o seu próprio dinheiro, para não depender só do marido. E até para ajudar eles. Porque eu acho desumano a mulher que não trabalha e o homem tem que trabalhar, trabalhar, trabalhar. Eu acho que tem que ser partilhado. Eu acho que a mulher, dentro do que ela puder - não abandonar o lar, nem abandonar as crianças -, mas se ela puder ajudar na construção dos bens materiais da casa, acho que é importante até para a mulher ocupar esse espaço na sociedade. Que ela não fique só dona de casa. É gostoso ser dona de casa, mas depois você percebe que podia ter feito um pouquinho mais.

Mas no momento não dava para fazer porque a gente não tinha suporte nenhum. Não tinha creche, não tinha quem ficasse com as crianças. Ficava amarrada: as crianças pequenas, ele trabalhava o dia inteiro, à noite também não ficava em casa, e eu morava num bairro em que eu não conhecia ninguém. Quando eu me mudei para cá era muito difícil. No começo era muito difícil.

Praticamente, ele não viu as crianças crescerem. Ele chegava em casa, eles estavam dormindo. Saía, eles estavam dormindo.

É o seguinte, a única coisa é que eu gostaria de deixar o meu nome na história. Sei lá... Eu acho que a minha jornada ficou incompleta. Eu poderia ter ido mais além. Mas eu gostaria muito de deixar o meu nome na história. Quer dizer, que eu já fiz parte de alguma coisa... que eu construí alguma coisa .

Eu acho que parei num momento e depois não continuei. Então faltou... acho que o que faltou... deixar o nome na história de uma forma... sei lá... de uma forma mais legal. Sei lá.

\section{ROBERTO}

Ah, mas você colaborou bem, você fez o melhor que você pôde, ajudou muita gente. Ajudou a comunidade em que você vive, cumpriu sua missão de mãe, esposa, você foi uma excelente mãe, excelente avó, excelente companheira. Então você cumpriu a sua missão.

\section{MESSIAS}

Mas eu não deixei o meu nome na história. (risos)

Ah, podia ter sido uma vereadora. Teria sido... uma prefeita.

\section{GUSTAVO}

Não sei.

\section{MESSIAS}

Podia.

\section{GUSTAVO}

Não sei, porque... Olha, eu tenho conversado com muita gente. E quando se fala nas pessoas, nas lideranças de CEBs, quase todo mundo acaba citando o seu nome.

\section{MESSIAS}

Messias? 


\section{GUSTAVO}

É.

MESSIAS

NOSSA!

\section{GUSTAVO}

Você, a Antônia, a Hosana. Então, acho que você nem sabe, e está com o nome...

\section{MESSIAS}

... Na história.

\section{GUSTAVO}

É importante para a comunidade.

\section{ROBERTO}

Que ficou, né.

\section{MESSIAS}

Que ficou na história, né.

\section{GUSTAVO}

É.

\section{MESSIAS}

Então, mas eu acho que falta alguma coisa. Falta alguma coisa concluir, que eu não sei muito bem o que é. Sabe quando você está ali no topo e você pára? E você podia ter continuado, para ver onde ia dar.

Eu parei porque... não deu. Eu tive que ficar em casa cuidando da família. Eu tive que fazer uma opção. Eu acho que a minha família precisava muito de mim. Então, eles eram mais importantes. Aí, eu parei. E eu não voltei mais para a comunidade. Quando eu parei, eu não voltei. E mesmo porque o espaço já estava ocupado por outras pessoas. Quando você volta, você já é como se fosse um intruso.

Você deixa o seu espaço, o outro ocupa. É normal. E se você voltar e começar a fazer de novo, eu acho que com o tempo a pessoa volta a fazer sempre. Mas eu acho que é mais trabalhoso começar de novo. Você passou muito tempo construindo. Para construir de novo, demora um bom tempo, porque são outras pessoas. Então, as cabeças delas estão... não estão prontas. Então, eu acho que é trabalhoso isso aí. Só por isso.

Também não tenho mais aquela vontade de ficar... Eu continuo ajudando as pessoas. Às vezes, se tem uma pessoa doente, eu vou lá e levo a comida, ajudo. Se tem uma pessoa precisando de ajuda. Se alguém está precisando de remédio, eu sempre ajudo. Mas são coisas, assim, esporádicas, individuais. Continuo participando assim. Mas atuar, eu não estou atuando. Participar sim, mas atuar não. Tem as novenas de rua, eu continuo participando.

Eu gosto muito de trabalhar com as crianças. O meu maior prazer é ver a casa cheia de crianças brincando. É fazer festa para elas. Eu gosto muito de trabalhar com as crianças. Acho que criança tem uma alegria tão grande, tão imensa, que sei lá... Você rejuvenesce perto deles. E os jovens também. Então, eu gosto de trabalhar com esse tipo de faixa etária. É muito legal isso aí. 
De tudo o que eu aprendi. Nossa! Eu não sei te explicar, porque é uma coisa que você não percebe. Você só dá conta de tanto aprendizado, quando você... Eu acho que por mais que eu tenha aprendido, eu acho que a gente não sabe tudo. Na verdade, a gente não sabe nada. Mas a experiência de vida é muito gratificante, porque você aprende a se doar, você aprende a conviver com as pessoas, você aprende a respeitar o limite dos outros, você aprende realmente a conviver em sociedade. Porque tudo você tem que trabalhar em grupo. Então, não é o que 'eu' acho, é o que 'nós' achamos, o que 'nós' pensamos. O que é melhor para todos. Então, eu acho que nessa experiência a gente aprende bastante... a trabalhar a fé dentro de cada um. Trabalhar o conjunto da fé. Eu acho muito enriquecedor isso.

E assim, eu acho que esses trabalhos preencheram um vazio enorme que eu tinha na juventude. Sabe, esse vazio... tipo um vazio de peso, falta alguma coisa. Eu acho que esse vazio foi preenchido. Eu sou uma pessoa feliz. Não tenho juventude, como eu te falei. Mas eu me sinto uma pessoa feliz, realizada. Porque a gente batalhou bastante pelo bem comum. Não foi só para a minha casa, só para mim. Eu não consigo ter essa visão de trabalhar só para mim. Quando é para mim, eu não trabalho. Eu não faço nada para mim. Mas for para todo mundo, para ajudar, aí eu trabalho. Mas para mim eu não consigo. Não sei... está dentro de mim. Eu sempre fui assim. A gente trabalha para Ele, né. "Eu estando bem...", não. Eu sou feliz quando eu faço para os outros. Para mim, não. Não consigo ir lá e fazer para mim. Coisa mais sem graça fazer para mim, né. Eu não sei...

Olha, eu não vejo quantitativo, mas eu vejo que atuar nessas questões... acho que é o sentido da minha vida. Se você pode definir, era tudo para mim. Me sentia muito bem fazendo, gostava do que fazia, fazia com amor. E onde eu pegava para fazer as coisas, as coisas realmente saíam. Porque não tinha dinheiro, não tinha política, era só mesmo a doação, o trabalho. E as pessoas viam, elas percebiam. Então, elas se ajuntavam, porque elas viam que era uma coisa boa. Então, eu acho que se a minha vida não fosse assim, não sei como seria. Não sei se eu seria diferente. Não sei se eu saberia ter vivido tudo isso sem ter feito essas coisas. Acho que eu faria de novo. Se eu tivesse que nascer e fazer, faria tudo de novo. Porque é uma coisa que está dentro de você. Está no sangue, está na alma, no ser. Está dentro de você. Então, é a necessidade que você tem de fazer isso. Você sente necessidade de fazer, DE PARTICIPAR, de fazer as coisas acontecerem. Eu acho que é isso.

Então, para mim, faz todo o sentido. Não faria sentido se eu não... Se eu não tivesse vivido, como seria? Eu não sei como seria. Talvez eu fosse rica, tivesse estudado, se tivesse pensado só em mim, não tivesse ajudado minha mãe, meu pai, minha família, estaria satisfeita, eu não sei... Não sei... Mas eu não me imaginaria sendo diferente.

E até hoje, ele fala comigo. [refere-se ao Roberto] Ele, às vezes, fica meio assim, que eu sou muito mão-aberta. Eu estou ajudando um, eu estou ajudando outro, vou cuidando daquele... aí enche a casa de criança... Ele fica doido. Aquele monte de criança. E faz festa, e faz oração, e reza. Então, eu acho que eu não sei viver sem isso.

\section{ROBERTO}

É o inconsciente da JOC.

\section{MESSIAS}

Eu acho que foi tão forte, tão marcante, que é uma coisa que deixou sequelas, pode-se dizer. Deixou, assim, um preenchimento muito grande. E foi muito gratificante me sentir assim. Gratificada por fazer todas essas coisas. Eu me sentia bem. Eu acho que... eu não sei explicar para você, eu não encontro palavras... para te falar, mas isso faz muito sentido, sim. Eu não saberia ser outra, ser diferente. Não dá para mudar, entendeu? Se você é uma coisa, você é aquela coisa. Não dá para você ser diferente: "Hoje eu vou ser isto, amanhã vou ser 
aquilo", sabe. Então, eu sempre vou buscar lugares e pessoas com quem dá para construir alguma coisa juntos. Senão, não. Esse negócio de ir lá e fazer alguma coisa para eu ganhar dinheiro, para mim, eu acho que eu não faria. Eu não sei que raio de coisa que acontece comigo!

Até hoje eu não escutei explicação. Talvez você, como psicólogo social, sabe definir. (risos) Eu não sei te dizer. Então, sei lá. Não sei se é uma carência, eu não sei se isso veio de uma juventude pobre, não está bem assim. Eu sei que foi bom. Fez crescer bastante, ter uma visão diferente, enxergar o mundo, ter uma visão larga das coisas. Eu acho que foi muito bom.

Olha, eu ultimamente estou mexendo muito com planta. (risos) Planta é o meu lazer. Mas eu estava pensando em ir fazer um curso. Porque tem essa neta que mora comigo. Os pais delas se separaram, e ela está morando comigo já faz algum tempo. E eu acho que ela precisa muito de mim, é preciso construir alguma coisa para não deixar ela desamparada. Então, eu ainda não posso me abdicar. Eu fico pensando, imaginando, o que eu poderia fazer. Às vezes, eu penso em fazer um curso de plantas, de atuar, até para trabalhar junto com ela, e até para colocar outras crianças com necessidades. Para trabalhar junto, dar uma oportunidade, essas coisas assim. Sei lá, eu penso assim. Construir alguma coisa. Eu pensei em formar alguma coisa que pudesse gerar renda não só para ela, mas para outras pessoas também. É tudo nesse sentido. Não sei se você consegue entender a minha cabeça. Então, eu nunca vou enriquecer. Eu vou ficar sempre pobre.

Eu só penso assim: que nesse mundo, nada te pertence. Quando você nasce, está tudo aí. Você morre, fica tudo aí. Então, eu sempre falo com ele: "Pra quê ficar acumulando bens, enquanto à sua volta tem um monte de gente necessitada? Um está com fome, outro está doente, coisa e tal". Então eu penso assim: a gente vai embora desse mundo, só vai levar o que você plantou. Ou o Bem, ou o Mal. Então, eu procuro tratar bem as pessoas como se fossem os meus, que eu criei. Trato bem as crianças, os animais, os mais velhos. As pessoas que vêem na minha casa, as crianças, a gente procura acolher da melhor maneira possível. Eu sempre faço um bolo, alguma coisa, deixo elas dançarem, brincarem. Eles pegam o brinquedo, brincam. Então, se eu vou acolher, cuidar de alguém, eu tenho que dar o melhor de mim. Eu exijo muito de mim. Dar o melhor que eu posso. Eu não dou o pior, dou o melhor. Então, acho que partindo desse princípio é que eu sempre procuro fazer alguma coisa, procuro fazer o melhor.

Se eu for fazer uma festa de rua, eu quero fazer a melhor festa. Se eu vou fazer, organizar qualquer coisa, tem que ser uma coisa que valha a pena. Senão eu não participo. Eu deixo. Eu não consigo fazer nada meia-boca. Eu acho que tem que ter alguma coisa muito concreta e muito palpável, senão eu não me enfio de cabeça. Se eu não conseguir, eu prefiro me afastar do que fazer mal feito. Ou eu vejo que vai prejudicar alguém, eu não entro.

Eu nunca pensei em construir nada para mim. É que eu acho que... essa vida, ela tem que ser bem vivida, cada momento de sua vida. Tem que ser bem participada, bem atuada. Tratar melhor o outro, o seu vizinho. Porque eu acho que os seus vizinhos é como se fossem família. Melhor do que família. Se morre, o vizinho é que está aí do seu lado. Se o vizinho não chamar ninguém, você fica aí, morto. Até chegar o parente, já morreu, já acabou. Então, é o vizinho que te acolhe.

Eu trato bem as crianças, os velhos, todo mundo. Eu procuro dar o melhor de mim. Talvez o melhor de mim não é o que o outro esperava, mas é o que eu consegui. Na minha cabeça é o melhor. Então, se eu vou me engajar numa coisa, tem que ser uma coisa que realmente vale a pena. Eu posso realmente me doar, fazer algo de bom para aquela pessoa, construir alguma coisa de bom. 
Eu acho assim: não é que você não vai estudar, não vai trabalhar, não vai construir a sua casinha. Isso aí necessário. Todo mundo tem que ter uma casa, um telefone, um carro. Não é luxo, isso é necessidade. Mas você não vai ficar construindo montanhas de coisas, que isso aí eu acho besteira.

A gente tem que ser o melhor vizinho possível. Assim, você não causa nem sofrimento para você, nem para quem está ao seu lado. Geralmente é sofrimento. E mesmo se você fizer tudo isso, você ainda gera sofrimento. Quer dizer que a gente pensa que está fazendo um bem, e está agindo incorreto.

Aqui na rua tem uma senhora que sempre ajudou nas quermesses e nas coisas da rua, e nas discussões. Ela é uma senhora cheia de problemas. Ela perdeu um filho com 12 anos que morreu afogado e ela estava junto. Ela não conseguiu salvar. Aquilo perturbou um pouco ela. E aí, Gustavo, hoje ela passa na rua e fala: "Oi, Messias". Amanhã ela passa perto de você e nem te conhece. Aí, brinco com ela, e falo assim: "E aí Vânia, não me conhece mais?". E ela: "Oi, dona Messias. Tudo bem?". E eu: "Tudo bem". Pensa assim: “Ô mulher esquisita, passa na rua e nem me olha". E já fica com raiva. Eu nem dou bola.

Tinha umas mulheres que viviam metendo o pau em mim. Elas sempre se reuniam, e quando eu saía, que elas estavam na rua, e eu ia saindo, elas ficavam fofocando sobre mim. E eu sabia que elas faziam isso. Aí, um dia, eu cheguei perto delas e falei assim: "Oi, mulheres. Bom dia".

Elas disseram: "Oi, dona Messias. Tudo bem?".

"Tudo bem". Aí, elas ficaram quietas, sem graça. "Ah... podem continuar. Podem falar mal de mim. Podem continuar que eu não ligo. Podem falar. Quanto mais mal vocês falarem, mais feliz eu fico. Podem continuar". Eu virei as costas e fui embora. Elas ficaram sem graça. Tem que ser assim. Não pode ficar brigando com as pessoas, porque é a opinião delas. São diferentes da gente. $\mathrm{O}$ conceito de vida que elas têm é diferente.

Aí, quando eu comecei a trabalhar no Grupo de Rua e na catequese, o pessoal da rua tinha as críticas, mas também o pessoal começou a ver o trabalho. Eles começaram a me respeitar. Aquelas crianças que brigavam de faca na rua, de se matar, as famílias começaram a se unir, e trabalhar junto, rezar junto. Aí, pararam aquelas brigas. A mãe brigava, o pai brigava, os meninos armados com faca. E um batia no outro. Pegava as cabeças assim. Era uma coisa de louco. Batia tanto a cabeça no chão que parecia que ia matar o outro. Volta e meia tinha briga naquela rua. Aqueles filhos do seu Miguel viviam armados. Um dia mataram ele numa festa. De tão ruim que ele era. E o seu Miguel sempre passando a mão naqueles filhos dele. E brigavam de faca na rua.

Foi daí que veio a ideia de trabalhar com as famílias e com as crianças: da necessidade. Havia uma necessidade, tinha que trabalhar essa questão. Foi daí que eu comecei a fazer as reuniões, a trazer a psicóloga para trabalhar nas ruas com as mães - tudo assim, terapia -, e trazer freira. Sempre tinha uma coisa diferente, atraente para atrair as pessoas.

E o trabalho com as crianças. Eu fazia teatro, fazia atletismo, fazia teatro na Igreja. Sempre naquilo que eu pudesse envolver as crianças em alguma coisa construtiva. Envolver. Você envolve as crianças, envolve os pais, e os pais participam. É nessa lógica aí.

E foi pensando nisso que a gente reuniu um grupo de mulheres que tinham a mesma visão, e que a gente começou a se unir e começamos a trabalhar juntas. A gente batia corda para as crianças, ensinamos elas a brincarem, a respeitar o outro, a se educar. A gente pulava amarelinha, brincava de alerta. Ficava brincando até nove horas na rua. Todas as mães ajudavam. Começaram a participar. E daí, a gente começou a fazer as festas, a reunir mais pessoas numa coisa boa. Uma coisa gostosa, que são as festas. Todas as crianças dançavam, e 
não precisava pagar os docinhos. A criança dançava e ganhava um kit: pipoca, refrigerante, um lanche, coisinhas assim, eles tinham o direito. E aí, era até gostoso, porque as mães começaram a entrar. Aí, todas as mães da rua começaram a participar. Acabaram as brigas. As mães pararam de brigar. Porque elas brigavam umas com as outras.

E as crianças. Nossa! Era terrível a rua. Nossa!, um bairro pobre, sem nada! Não tinha água, não tinha... Ave! Não tinha esgoto, não tinha nada. Você tinha que fazer um monte de coisas. Então, a necessidade faz com que você construa alguma coisa. Quando você não tem necessidade... Se você não enxerga as necessidades, não participa.

Então, havia uma necessidade muito grande. E eu era nova no bairro, na rua, não conhecia ninguém. E também tem a necessidade de ser aceito, de ser respeitado, de ser amado. Porque esses vizinhos, era um vizinho aqui, o outro ali, muito terreno vazio. Mas eles brigavam feio lá. Depois a gente ficou tudo amigo, tudo assim. Tem uma senhora que hoje ela é como se fosse minha mãe. Porque eu era novinha. Sempre que eu precisava, ela mandava as filhas dela me ajudarem, ficarem com os meus filhos. Se eu precisava sair, ela já tomava conta das crianças, sabe. Quando eu fiquei de cama, ela mandava as filhas dela me ajudarem, tomar conta assim, ajudar em casa e tudo. Com essa senhora até hoje eu tenho amizade. É uma senhora muito decente. É a dona Josefa. Ela participou muito dos movimentos, da Feira da Cultura...

Então, eu acho que para quem participou, havia a necessidade. Não era só o meu 'eu' Gratificar o meu 'eu'. É gratificante. Você aprende com tudo, mas também havia a necessidade.

Porque as CEBs era mais um movimento de revolução de ideias. Não era pegar em armas. Era uma revolução. Você caminhava de um jeito, você vai passar a caminhar de outro jeito. A Igreja estava assim, passa a ter uma Igreja diferente. Então, era uma revolução de ideias. Você muda todo aquele conceito de Igreja, de padre, de Deus. Até a maneira de se olhar Deus: você olhava Deus lá em cima. Nunca vê Ele. Ensina você a ver no outro, no irmão, na necessidade do outro.

Acho que a sociedade hoje está sem uma referência. Sem um ideal.

Não sei, eu acho que os jovens estão desmotivados mesmo. Eu acho que está um pouco parado. No tempo em que a gente estava na escola tinha música, tinha atletismo dentro da escola, tinha assistência social dentro da escola, tinha tudo. E eu participava muito daqueles negócios de festas da escola, reuniões de pais e mestres. Então, a comunidade da minha rua ia ver outras mães, porque é interessante a gente estar dentro da comunidade da escola. Então, a gente fazia missa, também, dentro da escola; a gente participava das festas juninas; tinha muitos pais que participavam e as crianças participavam junto com a gente. Tinha festa na escola, os pais vinham em peso. Hoje, na comunidade da escola, faz uma festa, quem faz? Os jovens. Mas quem participa? Só eles. Não vai família.

Eu fui no curso do Leonardo Boff uma vez. Eu não gostava muito das ideias. Mas o Clodovis Boff pegava mais na Teologia da Libertação: como você vê esse Deus no meio do povo. E tinha formação com outros padres, de fé e política, como você vê a fé dentro da política. Eram uns cursos de formação para catequistas, para animadores de Grupo de Rua, da CEBs.

Eu acho o do Leonardo muito assim... ele era muito radical. Eu tinha um certo medo das ideias dele, sabe. Era muito radical. Ele queria uma sociedade justa, mas muito radical. Queria, sabe, derrubar mesmo, mudar as ideias da Igreja, de tudo. Eu já tinha uma certa formação, que veio de antes. Então, para mim era... mudar... Então, eu acho que aceitar aquelas mudanças... Para quem já estava engajado nas lutas, nos sindicatos, na política, via 
uma certa lógica, né, batia. Mas para quem saiu da comunidade, que não tem nada a ver, pra ir para as lutas, e mudar assim, você não consegue. Eu tive formação com o Frei Betto* e com vários padres que davam formação para a gente.

Foi bom, porque faz você saber como trabalhar com a sociedade. Se eles não dão formação, como você vai sair para a rua, você estar lutando, pegando em coisas, se você não sabe nem para quê está fazendo? O que está fazendo lá, entendeu? Você tem que saber o que está fazendo lá. Então, a formação é para isso. É igual um estudo, uma ferramenta para você procurar um emprego. É isso aí.

Então, eu acho que sei lá... eu acho que valeu. Você acha que hoje eu faria isso? Talvez eu fizesse. Eu acho que faria. Mas acho que hoje eu tenho a cabeça mais, assim... Não entraria tão, assim, afoita... muito cega nas coisas. Poderia ter trabalhado até melhor. Ter ajudado mais, talvez. A gente era muito ingênuo, muito menino, muito criança. E a gente era criança mesmo, que a gente veio da roça.

Eu não sinto falta de a Igreja ter a mobilização que tinha, trabalhando fé e política. Talvez ela faça falta para esses novos que estão lá. Para dar essa continuidade, essa visão da sociedade, porque eles não têm essa visão. Que a Igreja para eles é rezar, rezar, fazer quermesse, fazer bingo, ajudar o padre, deixar a igreja bonita. Eu acho que a Igreja é o povo. Igreja é o povo, não é o prédio. É a comunidade. Eles acham que a Igreja é o padre, fazem quermesse, essas coisas. Então, eu acho que para esses que estão hoje lá é que deveria ter isso daí.

Esses padres da Teologia da Libertação foram proibidos de continuar o trabalho deles. Muitos padres da Teologia da Libertação foram proibidos até de exercer o sacerdócio por causa desse tipo de ideologia. Eles faziam as celebrações sozinhos.

Tínhamos formação do ecumenismo. Quando os padres davam formação para a gente, eles davam ecumenismo, da incorporação, da cultura indígena, negro, afro, outras religiões. Tanto que quando a gente fazia uma celebração ecumênica tinha pastor, tinha a Haidi, que era da Igreja Presbiteriana. Tinha celebração ecumênica. Porque a necessidade é comum. Não é a religião. Que a religião é assim: eu vou na minha fé, mas na hora da dificuldade...

Eu parei de ir na Igreja, de achar que Deus estava só ali. Eu comecei a ver que Deus estava presente em toda a sociedade, em todas as coisas: nas pessoas, nos pássaros, nas coisas. Então, Deus está presente em tudo. Não está só ali naquela... Porque é isso que o pessoal vê. O pessoal vai na Igreja, que Deus está ali. Sai fora da Igreja, acabou a Igreja... Sabe, não é isso. Naquela Igreja você vai entrar em comunhão com os irmãos. Não é isso: entrar em comunhão com os irmãos? Vai partilhar e comungar com os irmãos. É uma afinidade. Agora, fora da igreja, você tem que trazer esse Deus para a sua rua, para a sua casa, para a sua luta, para as necessidades que existem. Senão, não funciona. Se eu vou na minha Igreja, volto para a minha casa e acabou, não existe mais Deus? Então eu vou cantar, eu vou rezar dentro da minha casa e acabou? Que raio de Deus é esse? É um Deus acomodado, você não acha? Então, a gente tem essa visão.

Mas a sua fé tornando-se uma política mais humanizada. Cobrando mais justiça e mais humanizada.Não assim, por exemplo: "Política que vai mandar na Igreja".

"Não. Se vocês quiserem o exemplo, copiem o que a Igreja tem", e passe isso para eles. Eu penso assim: uma política mais humanizada. Você entrar na política para tornar aquela política mais social, cobrar mais interesses comuns, e não só interesses de um grupo, de um partido. É isso. 
Não foi um conflito trabalhar fé e ação social, ação política. Muito pelo contrário. A gente se reunia... Quando faltava água, não faltava só para os católicos, faltava para todo mundo. Mesmo que eles não vão, mas a comunidade em peso estava lá. Eu não sei quem, se era crente, se era católico. Todo mundo está passando sede, você tem que reivindicar. Mas para quem trabalhava a fé e a política, você sabia o seu papel na sociedade, como você tinha que trabalhar essa questão. Não vai haver conflito porque o outro é crente. Você vai falar: "Ô, você é crente, você precisa ir". Não, nada disso. A fé dele é aquela. "O pastor deles não prega esse Deus". "Ah, mas a minha prega". Então, eu tenho que fazer de acordo com essa teologia, nesse Deus presente na vida do povo.

Se você for entrar no campo da Filosofia, você vê os filósofos dizendo que a fé é o ópio do povo. Porque, dependendo da fé, não te liberta, ela te castra cada vez mais. Dão para você, você bota aquilo na cabeça e acabou. Então, quando se trabalha nas CEBs, te dá uma formação nesse sentido. A formação das CEBs é uma formação bíblica, para você entender o Evangelho e como você usar esse Evangelho no cotidiano, nas necessidades da vida. Você vai trabalhar com as diferenças. E trabalhar com as diferenças não é fácil. As diferenças de ideias, de fé. É muito difícil.

Dos bispos, eu acho que o mais lindo deles é aquele Dom Pedro. O Casaldáliga*. Na romaria que o pessoal fez lá para Crateús. Um lugar muito pobre, Crateús, Nossa Senhora! A Ilda está lá em Crateús. A Ilda veio aqui, acho que foi nas férias de julho do ano passado. Ela veio aqui na minha casa. Ela é assistente social e o marido dela dá aula, o Túlio. Mas ela é muito inteligente. Porque lá não dá NADA. Não se consegue plantar uma verdura, e a verdura chega no mercado já toda murcha. Não tem água. Onde sai água da pia dela é que brota alguma coisa, ainda nasce alguma coisa, porque a pia molha. É uma miséria muito grande. E ela foi para lá em missão da Igreja mesmo, do Servo Sofredor. Ela foi trabalhar lá em missão. Mas agora já cumpriu a missão dela e está querendo voltar. Os filhos dela estão todos moços. O Túlio dá aula lá em escola pública. É o marido dela e ela é assistente social. Mas ela continua botando pra quebrar lá, reivindicando as coisas, sai na televisão. Ilda era companheira de trabalho. Eu gostava muito de trabalhar com ela. Ela tinha cabeça... catequista também, com a cabeça muito aberta, muito inteligente. Ela, a irmã Rosina, nós trabalhávamos juntas. Porque era gostoso estar junto com elas. Porque elas tinham mais ou menos ideologia, ideia de como fazer as coisas. Não tinham tanto conflito. E é muito bom trabalhar com ela. E até hoje ela continua.

A comunidade da irmã Rosina, depois que ela morreu, as freiras que ficavam aqui foram embora. Mas tem a Selma, que é do Servo Sofredor. Que é dessa comunidade do Servo Sofredor. As outras foram embora. E a Selma era o braço direito do padre Alfredinho. Você vai ter histórias muito lindas.

Foi fácil lembrar. Porque é uma coisa presente na sua vida. Não é porque você está parado, que você não está atuando... essas coisas não morrem.

Ofereço essas memórias ao meu amigo padre Mahon. 


\section{REFLEXÕES}

\subsection{Memória e fé}

5.1.1 Sagrado no mundo, sentido na vida, tudo religado

O personagem Riobaldo, em Grande sertão: veredas (ROSA, 2001), em certo momento intui a totalidade da qual participa, tonteia, e tenta reconstruir o significado dessa experiência:

Porque a cabeça da gente é uma só, e as coisas que há e que estão para haver são demais de muitas, muito maiores diferentes, e a gente tem de necessitar de aumentar a cabeça, para o total. Todos os sucedidos acontecendo, o sentir forte da gente - o que produz os ventos. (p. 327).

Com tudo acontecendo e sendo ao mesmo tempo, com o que veio antes e o que virá depois, haja realidade para uma cabeça só. Riobaldo tem razão. Mas como aumentar a cabeça para o total?

Os narradores das memórias aqui presentes nos concedem percorrer com eles seus caminhos e respostas, suas angústias, seu entusiasmo, suas percepções profundas e interpretações mais preciosas sobre essa realidade tão estonteante de grande. É uma aventura pelo real, com a substância das experiências vividas e com a corajosa tentativa de reconstruir o real para nós, que também o experimentamos e por isso podemos desejar compreendê-lo através das estradas que estes narradores nos abrem, generosamente, em suas trajetórias.

Abrir a cabeça para o total... Aqui, se esse total nos escapa ou é alcançável de alguma maneira, vamos descobrindo aos poucos a partir das reflexões que se seguem daqui por diante. Será uma caminhada coletiva com nossos quatro narradores, e todos os narradores que os habitam; mais alguns companheiros andarilhos que com seus estudos e produções teóricas participam dessa trilha e dialogam animados conosco; e eu, que, de certa forma, vou apresentando os viajantes uns aos outros. Ah, sim, há também a presença imprescindível do leitor, que está convidado a trocar muitas ideias a respeito desta caminhada durante a leitura das reflexões.

Ao que parece, há muitas maneiras e esforços para alcançar a realidade. Uma delas é especialmente cara aos narradores destas memórias. Trata-se do esforço em re-ligar todas as coisas num manto de sacralidade e tecer sentido entre linhas, entre pontos, entre passagens 
que compõem a vida da qual participam. Tudo podendo ser mais. Desembocando a realidade vivida num ponto transcendente. Deus que se faz presente em tudo.

Presente no homem que apareceu na frente do ônibus quando a irmã de Madalena estava dependurada prestes a cair. Presente na psicóloga que aconselhou Margarida a participar das atividades da Igreja e que implicou numa mudança radical de vida. Presente na memória da transformação da bala em fivela pelo padre ameaçado por um homem com revólver. Acontecimentos que vão, de memória em memória, extraindo o transcendente dos fatos compartilhados pelas pessoas. Tudo habitado por Deus.

Mas para eles, participantes de CEBs e grupos afins ao longo da vida, a presença divina no mundo tem formas preferenciais de se manifestar. Talvez a principal seja nas pessoas. E mais ainda nas pessoas em determinadas escalas de situações: o pobre, o pobre reunido como povo, o povo em luta, o povo celebrando.

Quando a lembrança traz esse Deus que caminha no meio do povo e se revela nas pessoas, quase sempre o entusiasmo do narrador brilha forte. Aliás, é bom lembrar que, originalmente, a palavra "entusiasmo" carrega um sentido de algo como "Deus agindo dentro de si”. E ali está este Deus dentro, no rosto, nas atitudes, na simplicidade epifânica das pessoas.

"Conheci muita gente boa, muita gente que realmente revela Jesus Cristo, muita gente que sabe falar de Deus com a vida, que leva esse Deus mesmo, de verdade, aonde ele caminha”. (Madalena)

Torna-se fácil enxergar Deus. Já não se concebe aquele inacessível nas alturas, sem qualquer canal de comunicação com a realidade mundana. Se esse Deus é transcendente, Ele também se deixa alcançar. Apresenta-se como habitante de gestos, de exemplos, de posturas de vida.

Ir à igreja como forma de se comunicar com Deus é vivido menos pela ritualística e mais por outros motivos, bem encarnados. Vestido com camisa, mãos calosas, segurando bebês no colo, abraçado com o cônjuge, cantando, esse Deus está tão próximo dos que aqui narram. Cada filho e filha confirmam a presença do Pai. Eis uma maneira humana de se referir ao divino.

"Em casa, a gente procura Ele, mas não é tanto. Nós temos Ele dentro de casa, mas Ele não está com a gente como quando a gente está na igreja. Porque estando na igreja, a gente olha no povão e fica sabendo que aquele povo é tudo filho de Deus. Todo aquele povo que está lá rezando". (Margarida) 
Se a motivação para ir à igreja ultrapassa somente a ritualística e se explica por razões de humanização do divino, então, trazer Deus para fora da igreja mantém a sacralidade de tudo aquilo que é habitável pelo transcendente.

"Eu parei de ir na Igreja, de achar que Deus estava só ali. Eu comecei a ver que Deus estava presente em toda a sociedade, em todas as coisas: nas pessoas, nos pássaros, nas coisas. Então, Deus está presente em tudo. Não está só ali naquela... Porque é isso que o pessoal vê. O pessoal vai na Igreja, que Deus está ali. Sai fora da Igreja, acabou a Igreja... Sabe, não é isso. Naquela Igreja você vai entrar em comunhão com os irmãos. Não é isso: entrar em comunhão com os irmãos? Vai partilhar e comungar com os irmãos. É uma afinidade. Agora, fora da igreja, você tem que trazer esse Deus para a sua rua, para a sua casa, para a sua luta, para as necessidades que existem. Senão, não funciona. Se eu vou na minha Igreja, volto para a minha casa e acabou, não existe mais Deus? Então eu vou cantar, eu vou rezar dentro da minha casa e acabou? Que raio de Deus é esse? É um Deus acomodado, você não acha? Então, a gente tem essa visão". (Messias)

Deus, que não se acomoda fora dos sofrimentos e alegrias humanas mas que se revela no âmago das situações vividas. Sendo o transcendente possível por meio das experiências simbolizadas humanamente, toda a realidade se torna solidária, confluindo para um sentido de totalidade. As celebrações da realidade do povo revelam uma grande riqueza simbólica. Nas missas, a luta entrava junto com os paramentos; os objetos do cotidiano eram alçados à posição de símbolos sagrados. Madalena se refere às missas com o padre Alfredinho no Vista Alegre e a outras na São Geraldo:

“Aí ele levantava e ofertava a enxada, apresentava tudo que a gente tinha lá. E mesmo aqui, sempre quando celebrava alguma conquista, e mesmo que não tivesse dado certo naquela época, naquele dia. No tempo da água era panela, era caldeirão, a gente fazia toda aquela apresentação... da vida.

Mesmo quando não tinha dado certo a gente celebrava, e combinava já pra ir num outro dia. Sempre a gente celebrava. Tinha os momentos de luta e no final uma celebração para a gente poder agradecer a disposição das pessoas”. (Madalena)

A memória da religiosidade conecta os usos das coisas: os objetos comezinhos, tão úteis na vida cotidiana, ingressam no rol dos símbolos da fé; enxada, panela, caldeirão, na missa, lembram a sacralidade do simples, dos instrumentos valorizados pelo uso que deles fazem e não pela capacidade de troca mercadológica. Todo emblema do trabalho das pessoas das comunidades é alçado. Assim, a vida do povo é valorizada em símbolos de seu cotidiano pelejado. 
Ecléa Bosi lembra o quanto Jesus enraizava as parábolas que contava na existência de sua gente, com quem compartilhava a vida. Pão, luz, sal, fermento, semente de mostarda tornaram-se símbolos universais a partir da cultura da época. Captam o intemporal sob a espécie do temporal. "Um profundo desejo de tornar a verdade visível faz o artista elevar as coisas simples enquanto as torna habitáveis pela transcendência.” (BOSI, 2003, p. 207).

Também são unidos pelo liame do sagrado os muitos momentos temporais da realidade. A celebração unia passado e futuro. Agradecia pelo que tinha acontecido - "mesmo quando não tinha dado certo" - e preparava a esperança ativa no devir.

A memória da religiosidade vai conectando tempos e situações no percurso humano por esse mundo. Os povos oprimidos das narrativas bíblicas se encontram com o povo de Santo André. As passagens bíblicas se atualizam, servem de referência para o presente, fazem-se termos de comparação. Quando João conta que os ocupantes do Centreville não aceitaram mais o padre Mahon lá, lembra da traição de Judas a Jesus.

"Fizeram que nem Jesus Cristo. Jesus Cristo veio para salvar a humanidade e foi crucificado. E o Mahon lá para ajudar esse povo, apoiando esse povo, e expulsaram ele. Foi a mesma coisa de Jesus Cristo! A mesma coisa! Mesma coisa... Expulsaram ele... Aí, eles é que vieram... Vieram e se renderam ao padre Mahon. Pediram perdão e pediram para que fosse... E o padre Mahon com todo o carinho... O padre Mahon é muito bom, né! Ele é o mestre”. (João)

João também justifica a atitude política das CEBs comparando-a com a atitude de Jesus ao expulsar os comerciantes do Templo. Dois momentos de um mesmo projeto emancipador.

Entre tempos e situações que se ligam pela ponte do divino, Margarida cintila a radicalidade da experiência do re-ligar. Vai nos milagres de Jesus para trazer o significado sagrado que envolve suas lembranças do milagre da fivela e para ligar também nosso próprio encontro em sua casa. Tudo sendo milagre, sagrado no meio da gente.

"Você está percebendo que quando você saiu da tua casa para vir aqui, você está sentindo que não foi bem você que quis. Porque se fosse você que quisesse fazer isso, sem uma determinação de Deus, eu acho que não ia acontecer muito, não.

\section{$[\ldots]$}

Aí, você vai chegar lá e dizer: 'Olha, Bem, conversei com a dona Margarida. Ela conversa demais, fala muito, mas eu deixei ela feliz, deixei ela contente porque essa segunda vez nós conversamos coisas que eu nem sabia que poderia ter acontecido, que o crente atirou no padre, mas dentro do revólver tinha uma fivela', e naquela época também aconteciam essas 
coisas para o povo saber que existe Deus. Deus pode, de uma coisa, virar outra coisa. Ele praticou os pães, ele praticou os peixes, os animais para o povo comer, mas Ele também praticou dentro do revólver uma bala, porque o crente quis matar ele. Aquela fivela era uma bala, mas para mostrar para o povo que o padre mostrou, o povo viu uma fivela. Mas aquela fivela que o padre mostrou, foi para o povo saber que teve um milagre. Teve um milagre que não foi nem o padre que praticou, mas foi Deus quem praticou porque o padre estava trabalhando aquela obra de Deus e o crente veio matar ele.

É a mesma coisa aqui também. Aqui também é um milagre que nós praticamos". (Margarida)

Eu me sinto profundamente agradecido por Margarida incluir nosso encontro no manto de sua realidade sacralizada. E alguma coisa escaparia desse tecido que ela estende sobre o significado de sua vida?

O trabalho da memória vai dando efetividade a essa noção totalizante da vida em que todas as coisas se relacionam. Vai compondo o sentido da existência dos narradores. Como Madalena. Num momento, ela tateia com dificuldade o significado de sua história pessoal ao falar de sua entrada e saída do convento: "No começo de $80 \ldots$ começo de 80 não, um pouquinho depois de 80, eu fui para o convento. Foi muito interessante. Eu tinha assim, não sei... até hoje eu nem sei, realmente, qual é a minha missão. Acho que eu já vivi a missão tanto, que eu nem consigo assim...”.

A seguir, ela conta suas experiências no convento e os motivos de ter voltado para Santo André. Ela combina lampejos de sentido de vida com novas dúvidas.

"Daí eu vi que, realmente, a missão do leigo, do padre e da freira é a mesma. É você se colocar a serviço e servir, e pronto. Mas eu gosto muito das freiras lá de onde eu fiquei. Até há pouco tempo eu falei com uma por telefone. Voltei lá muitas vezes depois. Daí eu não voltei mais. Mas assim, só que eu não consegui ficar lá, não consegui. E eu fico sempre me perguntando: 'Não consegui ser freira, não consegui ficar casada, vamos ver o que eu vou conseguir fazer agora, né'. Mas acho que a minha vida é essa. Vivo assim”. (Madalena)

Enquanto narra suas memórias, ela vai elaborando em si mesma o sentido, vai ligando pontos, começa a tecer a unidade de sua vida. A base é a religiosidade em sentido amplo, como uma percepção da unidade radical das coisas do mundo, como sentido de vida que relaciona sua existência ao todo (cf. AMATUZZI, 1999). Sobre essa base que re-liga, ela se unifica a si mesma numa narrativa que, enquanto lembra, se revolve. Assim, iluminam-se princípios de respostas: 
"É uma experiência muito boa, de vida mesmo, sabe. Eu tive, assim, um crescimento muito grande. E quanto mais a gente caminha, menos a gente caminha, né? Quanto mais a gente aprende, parece que a gente aprendeu pouco ainda, né? E a experiência que eu tive é que, realmente, o que Jesus quer da gente é o serviço. A gente se colocar para servir mesmo, na gratuidade, na alegria. Não é nem servir de ficar fazendo tanto, mas servir de estar junto, caminhar junto". (Madalena)

Se pouco antes Madalena ainda tateava qual o sentido de sua missão, aos poucos a própria reflexão da narrativa memorial vai instaurando respostas. Ela afirma, ajeita a firmeza de seu espírito, quase conclui que sua missão, bem entendida, é servir, caminhar junto, gratuitamente. Oferecendo-se como eucaristia?

E, finalmente, Madalena nos mostra como o trabalho da memória se alia com o trabalho de sentido, de totalização. De sua busca nas recordações, traz vida nova para seguir caminhando.

"Nossa, voltei ao passado! (risos) Você viu, estou até mais animada, né. Nossa, dá um ânimo na gente, a gente lembrar de tudo isso. Que a gente tinha FORÇA para fazer tudo isso. Hoje acho que não tem mais. Mas a gente se anima. Só de pensar a gente se anima. É um ânimo novo. Uma vida nova. E eu fico feliz com tudo isso. Tanta coisa boa já aconteceu, e vai acontecer, com certeza, na vida do povo. Para construir essa história. Continuar a vida em Deus". (Madalena)

O passado é reconstruído a partir do presente, e o presente é ressignificado pela experiência narrada do passado. Um novo ânimo e a conexão de tudo o que foi vivido ativam a certeza de que assim como foi possível encontrar sentido nas relações entre os diversos acontecimentos do passado até aqui, o futuro também será tecido pela mesma continuidade de sentido, apesar das oscilações. Essa busca de sentido talvez seja um traço que perpasse gerações e períodos sócio-históricos ${ }^{5}$. Ela se manifesta de muitas maneiras, seja pelos condicionantes socioculturais, seja pelas singularidades individuais. Mas une tempos e pessoas.

Mais uma vez, Riobaldo nos convida às suas inquietações. Vamos mergulhar em seu dizer das coisas todas e tentar saber como ele busca sentido:

\footnotetext{
5 Aqui aponto a possível convivência entre as inquietações próprias da busca humana por um sentido absolutizante - portanto, trans-históricas - e aquelas inquietações inscritas nas contradições históricas. Em relação às reflexões sobre estas duas fontes de inquietação humana, sugiro a leitura de Análise do homem (FROMM, s/d), num viés ateísta, e Vida para além da morte (BOFF, 1991), numa abordagem de fé religiosa.
} 
Sempre sei, realmente. Só o que eu quis, todo o tempo, o que eu pelejei para achar, era uma coisa só - a inteira - cujo significado e vislumbrado dela eu vejo que sempre tive. A que era: que existe uma receita, a norma dum caminho certo, estreito, de cada uma pessoa viver - e essa pauta cada um tem - mas a gente mesmo, no comum, não sabe encontrar; como é que, sozinho, por si, alguém ia poder encontrar e saber? Mas, esse norteado, tem. Tem que ter. Se não, a vida de todos ficava sendo sempre o confuso dessa doidera que é. (ROSA, 2001, p. 500).

Essas inquietações, possivelmente comuns a todos os humanos, angustiam, mas também parecem tender do opaco à luminosidade. Viver como um exercício de apurar respostas. Ou perguntas? O lembrar como lapidação do que não tinha forma visível, apesar de existir. Sentidos que precisam ser burilados para se revelarem - ou se construírem.

Messias também nos conduz por sua jornada. Primeiro, o sentimento de que as coisas estão mal ligadas, incompletas. "Então, mas eu acho que falta alguma coisa. Falta alguma coisa concluir, que eu não sei muito bem o que é. Sabe quando você está ali no topo e você para? E você podia ter continuado, para ver onde ia dar". A seguir, volta-se novamente para o lugar de si mesma onde antes via a falta. Algo aparece. "De tudo o que eu aprendi. Nossa! Eu não sei te explicar, porque é uma coisa que você não percebe. Você só dá conta de tanto aprendizado, quando você... Eu acho que por mais que eu tenha aprendido, eu acho que a gente não sabe tudo. Na verdade, a gente não sabe nada". E quanto mais narra, mais reflete, mais enxerga. Messias vai ficando repleta. "E assim, eu acho que esses trabalhos preencheram um vazio enorme que eu tinha na juventude. Sabe, esse vazio... tipo um vazio de peso, falta alguma coisa. Eu acho que esse vazio foi preenchido. Eu sou uma pessoa feliz. Não tenho juventude, como eu te falei. Mas eu me sinto uma pessoa feliz, realizada”. E de tanto chegar à visão de sua própria totalidade, já começam a faltar palavras que deem conta do tamanho daquilo que se abre. "Eu acho que foi tão forte, tão marcante, que é uma coisa que deixou sequelas, pode-se dizer. Deixou, assim, um preenchimento muito grande. E foi muito gratificante me sentir assim. Gratificada por fazer todas essas coisas. Eu me sentia bem. Eu acho que... eu não sei explicar para você, eu não encontro palavras... para te falar, mas isso faz muito sentido, sim". A amplidão refaz a dúvida inicial em outros termos. Se em algum momento parecia faltar alguma coisa, agora parece que o que falta não é bem devido à escassez de experiência e sim devido à infinitude que se percebe ao percorrer as estradas da realidade, sua vida no meio do todo. "Eu sei que foi bom. Fez crescer bastante, ter uma visão 
diferente, enxergar o mundo, ter uma visão larga das coisas. Eu acho que foi muito bom". As expressões voltam a se abrir. Quando passou por todas as experiências concretas unificadas por um mesmo laço de sentido, Messias volta a ficar sem os termos mais precisos. Tocou de novo a imensidão.

Hélio Pellegrino (1987) faz uma bela reflexão sobre imensidão. Em diálogo com Lacan, fala-nos sobre essa agonia criativa de tentar dar expressão ao real.

O real - ser-em-si - é transcendente a nós, e não se rende ao humano discurso. Ele nos atravessa, nos constitui em nossa materialidade concreta, mas guarda silêncio, aquém - ou além - das palavras. O real está aquém ou além - do simbólico. Ele é simbolizável e, como tal, pensável. Mas, cerrado em sua noite, é guardião de seu próprio segredo. As coisas simbolizadas passam a representar um dado algébrico numa infinita galáxia de significantes, em movimento estrutural. O código lingüístico, as regras e prescrições da cultura, a Lei que os preside e organiza, tudo isso gera a possibilidade de infinitos discursos sobre o real. Ele próprio, mudo e quedo, traz em seu coração o mistério do Cosmo. (p. 322).

A realidade, na sua totalidade, supera a aparente fragmentação das coisas, atina para um sentido que unifica tudo, é simbolizado na referência ao que não consegue ser acessado ou traduzido diretamente. Essa superação pode estar ligada a um sentimento religioso em sentido amplo, como um re-ligar dos elementos da realidade. E as narrativas das muitas experiências significativas da vida organizam a percepção desse todo. Sentido de vida, totalização e religião conversam nas narrativas memoriais. Em direção à transcendência, essa totalização se decompõe em muitas expressões para se recompor no todo da compreensão - ou suas tentativas. Ou seja, existem experiências em partes do todo. Para os participantes de CEBs, algumas das experiências são marcadamente fortes como condensadores de sentido. Se o sentimento religioso re-liga a realidade, esta precisa ser apreendida pela práxis. De alguma forma, participação e engajamento colocam as pessoas em graus e posições de contato com a realidade que condicionam a maneira de vivenciar o sentido totalizante da vida e da realidade vivida. E isso, longe de ser fator limitante, é condição para conhecer - ou tatear - a experiência do real vivido, mesmo a que tende à transcendência mais plena.

Vale dialogar um pouco com Karel Kosik (1976, p. 22, grifo do autor): 
A dialética da atividade e da passividade do conhecimento humano manifesta-se sobretudo no fato de que o homem, para conhecer as coisas em si, deve primeiro transformá-las em coisas para si; para conhecer as coisas como são independentemente de si, tem primeiro de submetê-las à própria práxis: para poder constatar como são elas quando não estão em contacto consigo, tem primeiro de entrar em contacto com elas. $\mathrm{O}$ conhecimento não é contemplação. A contemplação do mundo se baseia nos resultados da práxis humana. O homem só conhece a realidade na medida em que ele cria a realidade humana e se comporta antes de tudo como ser prático.

Será que, nesse sentido, podemos conceber que mesmo a realidade transcendente ao nível mais absoluto pode ser conhecida no nível em que a práxis humana a cria? Veremos quais compromissos de práxis aparecem nas memórias e como se relacionam com os laços de sentido totalizante até aqui aludidos. A experiência que fazemos do Deus em si, fazendo-se compreensível na experiência do Deus para nós. Ou, como diriam muito bem os nossos narradores, passamos a olhar mais de perto a experiência desse "Deus no meio do povo".

\subsubsection{Fé e compromisso}

"De que adiantava nós sermos povo da Igreja e ficarmos de braços cruzados na hora em que o povo mais precisava?”. (João)

Com essa pergunta sempre interpelando os participantes de CEBs, era preciso manter o olhar atento para as necessidades do povo. Era preciso avaliar sempre a realidade condicionada historicamente à luz das referências evangélicas. Era preciso, enfim, colocar-se em ação para mover e promover as circunstâncias em direção à referência ética assumida.

Se a religiosidade é vivida como totalização da realidade, unidade e sentido de tudo no todo, o Reino de Deus fornece, para estes cristãos, a imagem da harmonização perfeita do real, meta de sua esperança. Assim, a correspondência das condições desse mundo com o Reino de Deus é a medida de um devir que caminha pelas estradas do verdadeiro sentido, da confluência para o estado autêntico de vida. Da mesma maneira, as condições antagônicas à imagem do Reino podem simbolizar uma rachadura na realidade. Cristãos e militantes, nossos narradores contam sobre o esforço em intervir nas condições do mundo, de tal forma que empurram a realidade sócio-histórica para uma correspondência mais próxima com a imagem do Reino de Deus. Indicam a necessidade de resolver as rachaduras, tornar as condições 
condizentes com a totalidade abundante. Fé e compromisso, ações promotoras de vida, denúncia e combate das condições de morte. Vida e morte, talvez as duas verdadeiras oposições da espiritualidade cristã (cf. BOFF, 2008, p. 97). Se o projeto de Jesus é entendido como aquele que visa a vida em abundância (cf. BÍBLIA..., Jo 10,10), a coerência cristã busca a correspondência com este projeto. Nossos narradores mostram seu significado concreto. Tal como refletiu João, ser da Igreja e ficar de braços cruzados diante das necessidades do povo seria uma grande incoerência. Então, mãos à obra!

"No grupo de CEBs, a gente ou fazia o terço ou já fazia a parte do livrinho, sem o terço. Aí, tinha o Evangelho. Quando era preparado o livrinho, tinha o Evangelho. Tinha a História da Vida - às vezes o livrinho estava preparado com a vida da gente hoje -, e a história do Evangelho, ligada à nossa vida hoje. Aí, deixava aberto para as pessoas. Porque o nosso lema era assim: que todos falassem. Não era importante que eu ficasse falando. Importante era quando eu pedia à pessoa, que quisesse falar sobre aquele problema, e ele colocava: 'Bom, na minha família acontece um caso parecido com esse'. A gente fazia ligação daquele Fato da Vida com o Evangelho. Aí, o outro colocava: 'No nosso bairro, o que pede aí no Evangelho, está pedindo no nosso bairro. Nós estamos precisando. Está precisando sermos unidos. Nós precisamos nos organizar"', (João)

A ligação entre os materiais usados nas reuniões - especialmente os livretos com os roteiros para os grupos - e a vida das pessoas procura incentivá-los a se colocar no mundo atual. Referindo-se a situações que até hoje podem ter ressonância na vida do povo, os livretos sugerem conexões entre circunstâncias diversas. A conversão pedida por Jesus pode sugerir uma mudança de mentalidade, de consciência diante da realidade atribulada de hoje. A abertura de coração e a benevolência para com os pobres, tal como aparece em Deuteronômio (BÍBLIA..., Dt 15, 7-11), pode sugerir atitudes de cuidado para com os jovens marginalizados, os pequenos agricultores, os enfermos, os desempregados, os idosos. Os textos dos evangelhos podem sugerir partilha dos alimentos e da vida, podem sugerir iniciativas para tornar a sociedade fértil para as sementes da felicidade plena, podem sugerir maior dedicação à caridade do que aos rituais e sacrifícios. Nas reuniões, Bíblia e vida do povo se fecundam mutuamente.

Outro ponto presente nas reuniões é o chamamento aos gestos concretos. Ainda hoje, os roteiros da CNBB para grupos sugerem práticas concretas em consonância com os temas abordados. São muitas as práticas narradas pelos memorialistas aqui. Desde a assistência caridosa aos enfermos até as ações políticas de grande escala denotam a importância dessa coerência entre fé e vida, Reino de Deus e sociedade humana, espiritualidade e compromisso 
sociopolítico. Esse compromisso concreto com o outro, esse comichão de promover a vida em todas as esferas possíveis, são marcas fortes que indicam o horizonte ético no qual essa fé implica. Foi sobre essa base de valores que eles passaram a se conduzir no mundo.

O teólogo Juan Luis Segundo (1997) discerne uma concepção de fé que ele chama de “fé antropológica". Para ele, todos nós aderimos a um ou mais valores supremos que guiam nossas vidas. Trata-se da aposta num caminho para chegar à felicidade. Porém, como não podemos nos antecipar ao resultado destes caminhos possíveis e, por isso, ficamos sem garantias de que seremos felizes ao fazer essa aposta radical, nós nos apoiamos no testemunho de pessoas que assumiram essa mesma estrutura de valores, confiando em sua referência. Jesus, por exemplo, pode ser uma testemunha de valores nas quais as pessoas decidem se apoiar. Nesse sentido, é possível buscar a fé de Jesus, assumindo ou não uma fé em Jesus como divino.

De acordo com essa concepção de fé - no sentido antropológico -, pode-se notar como as atitudes, liberadas do mero formalismo ritualístico, alcançam uma liberdade profundamente arraigada nos valores promotores de vida. Acima de quaisquer sectarismos, os narradores lembram a atitude larga de comunhão que buscavam com seus semelhantes diante dos desafios.

"Não foi um conflito trabalhar fé e ação social, ação política. Muito pelo contrário. A gente se reunia... Quando faltava água, não faltava só para os católicos, faltava para todo mundo. Mesmo que eles não vão, mas a comunidade em peso estava lá. Eu não sei quem, se era crente, se era católico. Todo mundo está passando sede, você tem que reivindicar. Mas para quem trabalhava a fé e a política, você sabia o seu papel na sociedade, como você tinha que trabalhar essa questão. Não vai haver conflito porque o outro é crente. Você vai falar: 'Ô, você é crente, você precisa ir'. Não, nada disso. A fé dele é aquela. 'O pastor deles não prega esse Deus'. 'Ah, mas a minha prega'. Então, eu tenho que fazer de acordo com essa teologia, nesse Deus presente na vida do povo". (Messias)

Aqui, Messias mostra como a fé - e os valores - à qual aderiu impulsiona a práticas sociais concretas voltadas para favorecer a vida das pessoas. Fé que considera o mundo e, especialmente, o povo, como portadores do sagrado. Nota-se que há uma adesão a valores ligados à defesa e promoção da vida como fins.

Gestos concretos são uma tônica nas narrativas. Margarida vai atrás dos mais pobres, marginalizados e maltratados. Quer esparramar todo o entusiasmo dessa fé em ações que repercutam nos que estão com a vida mais esmagada. João participa de sacoladas para juntar mantimentos, entra em partido político, envolve-se nas lutas da região. Messias narra a 
compreensão a que chegou de que Deus deve estar na rua, nos pássaros, no povo, e não somente dentro da Igreja; e assim, promovia todo tipo de espaço de convivência que curasse as relações sociais dos moradores do bairro - aí onde Deus está. Madalena recorda saudosa as tantas atividades políticas, assistenciais e cooperativas que a fé suscitava.

Fé e compromisso povoam as memórias de sentido. Não se trata de uma relação de fé que se esgota na experiência individual. O novo ânimo que abastecia os participantes de CEBs somente se completava quando encontrava outras pessoas nas quais poderia se transmitir. Assim como numa partilha de alimentos, quanto mais cada um divide o que tem, mais abundante se torna a refeição de todos.

"E nós temos que fazer isso. As CEBs foram um meio de comunicação para a gente poder saber como é que a gente trata o nosso irmão. A oração ser uma oração forte para nós. Fazer a nossa oração, nosso retiro, mas de lá a gente achar que o retiro não é uma coisa qualquer, e que a gente tem que saber que daquele retiro vai ter que trazer alguma coisa linda, bonita, para eu dizer para você. Dizer para você que as CEBs são um meio de comunicação do povo para deixar o povo tranquilo, feliz, não chicotear". (Margarida)

Felicidade para os que eram constantemente chicoteados pelas condições de vida sofríveis. Oração forte, aquela baseada na coerência de conteúdo entre a oração e a postura de vida. Valores que deságuam numa busca que sacraliza a realidade. Tudo pode estar permeado e habitado por Deus. Por isso, tudo merece atenção e desvelo. Tirar a realidade do chicote e colocar na felicidade.

Assim, os narradores narram suas vidas e suas concepções de fé. Não seria possível se aproximar desta fé sem se aproximar da vida mundana. A única dicotomia que emerge é entre vida e morte: condições que favoreçam uma ou outra. E aqui fica claro qual é opção dos narradores e do povo presente em suas narrativas.

De alguma forma, essa fé se relaciona com um Deus libertador, engajado no cultivo da vida, companheiro de atuação, inspirador de horizontes que não se esgotam em algumas experiências ritualísticas, mas que se abre na experiência religiosa com um todo, religando toda a realidade num horizonte de abundância. Se há muitas carências, a realidade precisa ser concretamente cultivada para realizar-se em sua essência de totalidade abundante.

"Nos Grupos de Rua se discutia. E daí um grupo tinha uma ideia, já trazia para cá, e se dava para aproveitar, já aproveitava. Os grupos discutiam o que iam buscar de melhor, e sem esquecer também o lado religioso. Se rezava bastante. Tinha muita espiritualidade, tinha bastante também. A gente não ficava só na reza, lutava bastante. Mas tinha também muitos 
momentos de espiritualidade. Celebrava, né. Se celebrava muito. Ixi, quantas vezes a gente conquistava um negócio, enchia essa igreja pra rezar uma missa”. (Madalena)

As práticas religiosas e políticas, interligadas, eram um memorial da totalidade uníssona da realidade. O compromisso de fé e o compromisso social e político também se fecundavam mutuamente.

É preciso recorrer ao contexto histórico que dialoga com o desenvolvimento das CEBs. Ao emergir das condições sociais e das respostas dos cristãos frente à realidade conflitante e desigual da América Latina, o Cristianismo da Libertação, tal como foi denominado por Michael Löwy, trata-se da rede de movimentos religiosos laicos, setores das Igrejas - principalmente Católica, mas também Protestante -, comunidades de base, pastorais, organizações populares, sindicatos etc. O conjunto desse movimento, surgido na década de 60 , inclui tanto a cultura religiosa quanto a rede social envolvida, do qual decorre sua expressão teológica na Teologia da Libertação (cf. LÖWY, 2000).

Os teólogos desta expressão, nutridos tanto pela práxis do povo em movimento quanto pela fé cristã, colocam-se o desafio de elaborar uma teologia crítico-concreta coerente com os desafios latino-americanos. Por isso, fazem uso das ciências sociais críticas, frequentemente dialogando com o instrumental de análise marxista, seletivamente, no que é avaliado como compatível com os fundamentos da fé cristã, articulando a mensagem evangélica com a concretude sócio-histórica (cf. DUSSEL, 1999). Apesar das diferenças entre os teólogos da libertação, algumas características são comumente compartilhadas como: a valorização dos leigos nas atividades e decisões eclesiais; a ampliação da noção de pecado para além do âmbito individual, direcionando-se à noção de pecado estrutural e social; a crítica à sociedade capitalista; a opção preferencial pelos pobres, considerando que os próprios pobres devem ser os sujeitos históricos de sua libertação; a elevação das relações comunitárias como referência de relações sociais; a ênfase na centralidade da leitura bíblica direta; a associação da libertação humana e histórica à antecipação do Reino de Deus, articulando a história humana à perspectiva de horizonte transcendente; entre outras.

No contexto das práticas do Cristianismo da Libertação e das reflexões da Teologia da Libertação, vários grupos se formaram, se consolidaram e se desdobraram. As CEBs são centrais nessa história como uma das principais manifestações dessa vertente cristã. Assim como a práxis dos participantes de CEBs e grupos afins foi alimento para o desenvolvimento das abordagens teóricas do Cristianismo da Libertação, da mesma maneira, suas 
manifestações teológicas, pedagógicas, psicológicas e filosóficas ${ }^{6}$, foram alimentando os grupos com os frutos de suas reflexões.

No caso dos nossos narradores, também é imprescindível lembrar que os padres da Congregação dos Filhos da Caridade são responsáveis pela Paróquia São Geraldo desde 1971. Esta congregação religiosa se caracteriza, em linhas gerais, por assumir sua missão nos bairros populares, junto aos trabalhadores, marginalizados e excluídos das conglomerações urbanas. Seu fundador, o padre Jean-Émile Anizan (1853-1928), identifica sua vocação como chamado para atuar em favor dos pobres e dos operários, dirigindo-se aos locais onde viviam as famílias trabalhadoras dos arredores de Paris. Ao enfatizar que o próprio Filho de Deus foi um operário e que isso foi um fator fundamental na sua perseguição pelos poderosos, padre Anizan chama à reflexão:

Vocês entendem, caros amigos, qual foi a Revolução que este simples fato realizou? Ah! Muitos se perguntam quando começou este movimento de valorização do trabalhador. Ele começou faz muito tempo, faz muitos séculos: ele começou no dia em que o Filho de Deus se fez operário.

Como ficar assustado ao ver que os apóstolos orgulharam-se em realizar trabalhos braçais; como ficar assustado ao ver que a Igreja sempre tomou a defesa dos trabalhadores nos quais via a imagem de seu Deus; como ficar assustado ao ver que a Igreja preocupou-se em juntar os trabalhadores para que, unidos, estejam mais fortes...? Toda a explicação está neste Jesus trabalhador: foi Ele que fez mudar as idéias, foi Ele que inspirou estas instituições... (ANIZAN, s/d).

O compromisso da fé libertadora se ramifica nestas relações dialéticas com as ideias e práticas que vêm movendo gerações de oprimidos em direção ao futuro emancipador. Quando cantam, suas músicas fazem essas gerações todas se abraçarem num mesmo projeto. Imagens antigas e contemporâneas unem forças. Na produção simbólica, em forma de canções, todas as influências recíprocas entre ideias e práticas que estão em ebulição se transfiguram em claridade.

\footnotetext{
${ }^{6} \mathrm{Na}$ linha da libertação, além da teologia, desenvolveram-se outras abordagens prático-teóricas: a Pedagogia de Paulo Freire, a Psicologia da Libertação, a Filosofia da Libertação.
} 
Pode acontecer de se lançar um olhar sobre os mecanismos de dominação na sociedade, unindo a crítica moral com a crítica socioeconômica. A beleza delicada dos cantos ecoa como um estrondo desafiador:

"Peregrino nas estradas

De um mundo desigual.

Espoliado pelo lucro

E ambição do capital". (Madalena)

Em outra música, a sociedade capitalista é criticada implicitamente na menção a figuras antigas. No lugar das fábricas, prédios governamentais e associações patronais, aparecem os palácios. No lugar dos patrões e dos governantes atuais, os príncipes. Assim, o que não podia ser falado diretamente, era cantado e contado de outro jeito.

"E nos palácios do olêlê, olêlê

moram os príncipes

sem saber que lá fora

que lá fora

a vida é triste". (Madalena)

Madalena ainda destaca, ao final de cada trecho cantado, uma parte que quer reforçar. "E lutar não foi em vão", diz ela, completando com um trecho da música Peregrino a ideia que precisa ser marcada fundo. Depois, repete sobre a segunda música aquilo que precisa ficar claro a muitos, como os príncipes, que não partilham das mesmas condições vividas pelos pobres: "A vida é triste e existe".

Em outra música recordada por Madalena, está a indicação de que suas referências dentro do Cristianismo da Libertação vão bem no âmago da força que a simplicidade tem. Ela canta um pequeno trecho:

"Virá o dia em que todos

vão levantar a vista

veremos nesta terra

reinar a liberdade". (Madalena)

Esta música prossegue com uma adaptação do Magnificat, recitado por Maria quando visita Isabel grávida de João Batista. A beleza desse canto é de grande valor para os pobres em luta pela libertação. Com sua simplicidade, Maria relembra a força dos humildes, que têm 
como aliado o próprio Deus. E a relação dos humildes com Deus revela a certeza de que serão exaltados e alimentados enquanto os poderosos serão derrubados de seus tronos ${ }^{7}$.

A valorização humana é visível na valorização dos analfabetos, dos favelados, dos sem-voz. Afinal, tendo Jesus de Nazaré como referência de valores, fica bem alicerçada a noção de que os pobres são bem-aventurados (cf. BÍBLIA..., Mt 5, 3; Lc 6, 20).

Margarida conta sobre sua própria valorização dentro das CEBs. Ela resistia a assumir um grupo como animadora por ter pouca leitura. Mas a insistência de Perseu ${ }^{8}$, companheiro de animação, fez com que se convencesse de sua capacidade.

“Aí depois, Gustavo, foi que eu fui perceber que para a gente gostar de Deus não precisa saber ler, não. Sabe por quê? Porque quando eu comecei, quando eu saí de junto do Perseu, eu já saí porque ele me esparramou outras coisas. Ele mandou que eu assumisse o meu grupo porque eu já era capaz”. (Margarida)

Margarida, quando se dá conta da riqueza que viveu em todos esses anos de participação, reflete: "Eu não sei ler direito, mas eu sei dizer para você... Desde a época que eu estou na Igreja São Geraldo nunca fui de outra igreja. Porque as outras igrejas são todas iguais. Mas a Igreja São Geraldo foi a minha comunidade, onde, lá, eu pude imaginar coisas importantes, foi onde eu pude participar da CEBs, foi onde eu pude, de lá, esparramar para o povo o que é a Palavra de Deus".

Ela, e tantos outros, perceberam-se como semeadores da Palavra de Deus mesmo sem ler bem, porque essa Palavra depende de uma formação teórica que eles têm acesso nas comunidades de base e de uma formação humanística que, em parte, já trazem e que se desenvolve nas experiências vividas comunitariamente.

Participar dos grupos de CEBs é retomar a voz que a sociedade de classes lhes calou. O milagre da cura do surdo-mudo (cf. BÍBLIA..., Mc 7, 31-37) é atualizado na cura da voz dos pobres, que passam a olhar a sociedade de frente, mesmo que seja "levantando a cabeça devagarinho", como dizia Madalena ao relembrar as palavras de Tetê.

“As CEBs, como eu falei para você, nossa!, revolucionou muito aquela época. Unia muito as pessoas. Quantas pessoas que participam ainda hoje na Igreja porque começaram no grupo de CEBs. É aquela pessoa que ninguém dava valor e ele, participando do grupo de CEBs, sentiu que tinha algo dentro dele para doar. Ele tinha valor. Era uma pessoa valiosa. E ele descobria esse valor aos poucos, se aproximou da igreja e começou a participar”. (João)

\footnotetext{
${ }^{7}$ Para conferir o canto Magnificat, ver a passagem do Evangelho de São Lucas (BÍBLIA..., Lc 1, 46-55).

${ }^{8}$ Daqui por diante, o uso de nomes reais ou nomes fictícios corresponde exatamente ao adotado nas narrativas (4 NARRATIVAS).
} 
Parte extremamente importante do compromisso desta fé é o de reerguer os caídos, curar os enfermos de suas opressões psíquicas e sociais. Enfim, valorizar as pessoas. E a própria dinâmica dos encontros e das relações favorecia isso. João lembra da orientação do padre Mahon: "Nas CEBs, a gente nunca é um grupinho fechado, é um grupo aberto, é uma pessoa aberta. É a gente de mãos dadas, mas de costas um para o outro, olhando para o povo".

Nos mínimos detalhes havia a preocupação em evitar colocar mais peso sobre os que já sofriam os fardos de sua condição. Cortaram o hábito de oferecer café durante as reuniões. Atitude antipática? Não. Para os mais pobres, até a impossibilidade de oferecer alimento aos convidados pode ser um empecilho à participação. Então, a austeridade material assumida nos encontros pode representar uma liberdade para o pobre, inimaginável para quem não sofre suas dificuldades extremas.

"Porque tinha época aí que fazia um banquete. Então, tinha pessoas que viam aquele monte de coisas para comer e beber, e na hora que chegava na casa dele, ele não tinha condições de dar aquilo lá. Então, ele não queria por causa disso. Chegou uma hora que a gente falou: 'Não, vamos cortar isso aí. Não dá nada, não'. Água para beber... tem que ter água. E tem água, não é? Então, a pessoa aceitava mais, porque não precisava dar nada. Quer dizer, ele, mesmo sem dinheiro em casa, vai poder fazer o encontro". (João)

Essa sensibilidade dos pobres para com os mais pobres é exemplo de atenção. Tudo fica sendo importante para promover a vida. A postura do animador vai se lapidando em direção à humildade. As lideranças vão percebendo quais atitudes são toques de amor e quais são empurrões humilhantes. João continua a nos mostrar os aprendizados que cultivou nas relações com os mais oprimidos:

"Nas CEBs, quem anima, tem que ser humilde mesmo. Tem que ser humilde. Ele tem que ser o pior de todos. Mostrar-se mais baixo do que todos. Para deixar o pessoal à vontade.

Falar: 'Eu estou aqui e eu sou como vocês. O que vocês sabem, eu sei menos ainda. Vocês sabem muito mais do que eu. Mas nós estamos aqui tentando nos consertar, tentando melhorar a nossa situação, na nossa cidade, no nosso país. A gente quer isso’.

Então, sempre se colocando abaixo deles, do pessoal. Nunca se colocar superior. Se começasse a falar superior na frente do pessoal - porque é povo humilde -, ia deixar eles muito rebaixados. Ia deixar pequenininho. E, na verdade, nós éramos iguais a eles, mesmo. Não era nada mais".

Tudo isso são demonstrações de respeito às pessoas, buscando nelas o que é mais fundamental, que no caso é a participação, a palavra, a visão de mundo, a esperança, a solidariedade delas e não o café. 
Nestas narrativas se anunciam os valores perseguidos pelos participantes de CEBs como estrelas-guias no meio da realidade. A vida, e seu cultivo, como culminância deste horizonte. No compromisso de abundância de vida para todos está a argamassa que une os ladrilhos deste mundo ao Reino. Na coerência entre o projeto do absoluto e o projeto sóciohistórico reside a fé enraizada do povo das CEBs. 


\subsection{Respostas ao sofrimento}

\subsubsection{Enfrentamento da humilhação social}

As lembranças dos oprimidos são repletas das dificuldades passadas. Mas, também, cheias de evocações das respostas e dos enfrentamentos a estas dificuldades. São lembranças dos golpes digeridos e enfrentados, como diria José M. Gonçalves Filho (2003).

Margarida lembra de quando era empregada doméstica. Sofreu alguns golpes e pondera sobre eles. Como ela mesma diz, tem gente que gosta muito de mandar, gosta de querer ser mais, enfim, gosta de ser muito "herói”. Aqui, herói não é aquele que salva nem emancipa, mas aquele que se coloca sobre os demais, que domina. Aqui, dizer "herói" enfatiza a característica de se colocar soberbamente, com atitude mandona.

Mas Margarida não se curva. No próprio ato de narrar essas relações criticamente, já é possível entrever uma resposta ao sofrimento, pois essa atitude da consciência impulsiona para além da passividade. O que foi sofrido não está engolido e perdido em algum lugar obscuro de si mesma. Ela devolve o golpe com a crítica. Ao avaliar a situação, isso mesmo já é parte da resposta.

"E aí, o meu problema é assim, sabe: todos nós somos iguais, não somos? Então, eu acho que em todo lugar tem que ter respeito também, não tem?”. (Margarida)

Ela sabe a resposta. Na verdade, ela responde. De um lado, a patroa que vigia, controla, passa o dedo nas coisas para checar a limpeza. De outro, a trabalhadora sob jugo. Mas também a trabalhadora que, ao longo de sua vida, aprendeu que todos têm valor. Será que a patroa imaginaria que aquela empregada doméstica aparentemente sem valor a seus olhos se tornaria uma liderança em seu bairro, que participaria de mobilizações, iria a manifestações de grevistas e seria referência de vida para tantas pessoas de uma região?

Mas o privilégio que a patroa tinha de estar perto de alguém com tantas potencialidades era, muitas vezes, despercebido. Assim, Margarida saía da casa e deixava para trás uma infeliz patroa que sequer suspeitava da infelicidade de que padecia. Já Margarida, com uma perda infinitamente menor do que a da patroa, levava para onde ia a sua dignidade. E narra o que já sabia: "Se eu não der valor para mim também... Assim como eu respeito, também tenho que ter respeito. Tenho que ter respeito para eu poder também dar respeito para os outros". 
Onde Margarida pode ter reforçado e aprofundado esse autovalor, mesmo com um histórico de dominação sofrida em sua vida? Talvez, no mesmo espaço onde João "descobriu que tem vez e voz", e onde aprendeu “a não ser explorado, a viver uma vida digna”.

Nas CEBs e em outros grupos afins, nossos narradores vão assentando bloco a bloco a certeza de que são valiosos a despeito de toda a desigualdade que a sociedade do capital impõe. O que sofrem é lembrado, mas sempre em companhia das respostas que dão aos sofrimentos. Sofrimentos que se voltam contra as pessoas não simplesmente por serem quem são. Aliás, falta exatamente o olhar atento a quem são, à sua profundidade pessoal. Constituem-se em golpes encadeados num infeliz lastro que une os que sofrem dominação.

José M. Gonçalves Filho (2007) reflete sobre o fenômeno da humilhação social. Trata-se de um sofrimento que, embora sentido por cada pessoa atingida, é causado por um golpe desferido por um ou mais grupos da sociedade contra outros grupos. É um ataque de longa duração, às vezes percorrendo gerações de pessoas que se veem rebaixadas como o foram seus ancestrais de bairro, de família, de raça, de classe etc. Sofrimento ligado diretamente à dominação e, portanto, de ordem política, causa um impedimento dos humilhados a experiências e sentimentos humanos como: a fruição da cultura, da beleza, do lúdico; a participação nos bens públicos; o sentimento de ter direitos; a posse de um rosto e um corpo visíveis e respeitáveis.

Às vezes, o golpe é desferido por pessoas que deveriam estar do mesmo lado. É o que narra Messias, contando como as mulheres de sua rua a maltratavam pelo fato de participar das muitas atividades político-eclesiais. A compreensão é uma das maneiras de responder, tendo um olhar atento às causas do fenômeno: "Mas, naquela época, não tinha mulheres que faziam isso. Acho que fui uma das primeiras. Era uma ou outra mulher que se reunia na Igreja no ABC. Ou que se reunia para organizar as coisas". (Messias)

Mesmo angustiada pelo que conta - é quase possível ouvir os xingamentos, fofocas e calúnias que Messias evita recontar com a boca, mas que diz com o rosto -, ela logo vai buscar na memória as repostas dadas. E não foram golpes na mesma moeda. Não. Ela deu um salto de qualidade, suspeitando que aquelas mulheres talvez só tivessem, no fundo, desejo de viver a mesma liberdade que ela. Assim, começou a explicar-lhes o que fazia e a incluí-las nas atividades.

"Comecei a levar, levar, levar, e aí acabaram os problemas. Quando elas começaram a participar, começaram a gostar, acabaram os problemas".

Messias, provavelmente, foi um canal de libertação para essas mulheres. Ao mesmo tempo, libertava-se da sequência de golpes que vinha sofrendo por ser mulher num contexto 
de dominação que já tinha golpeado tantas outras antes dela. Boa parte de seus agressores eram também mulheres. Mas, à medida que se organizam, elas ganham rosto, tornam-se pessoas, assumem uma resistência em comum, criam identidade umas com as outras. Transfiguram a hostilidade que exerciam contra si mesmas. E passam a olhar de frente o mundo, os homens, as pressões da humilhação de gênero. O grupo "Fé Menina" é bom exemplo de como as mulheres se colocaram frente à dominação que as golpeava.

"As mulheres começaram a mudar suas cabeças, a ter uma postura diferente. De sair de casa, de poder estudar, de poder trabalhar, de poder não pensar só em ficar dentro de casa.

$[\ldots]$

Daí que surge o movimento da creche, de ajudar essas mães a saírem de casa, até para ter mais dignidade.

As mulheres eram muito sofridas, muito maltratadas mesmo. Então, era uma questão de libertação da mulher. Para nós era essa questão: da libertação da mulher. A mulher como um rosto, como um ser humano. Porque atrás da mulher, não é mulher, é ser humano. Não é uma coisa abjeta, que você é usado, é maltratado. Então, é para dar uma certa dignidade". (Messias)

Uma outra fonte de agressão e humilhação social presente nas narrativas são as autoridades políticas constituídas. Os governantes, seguindo a corrente de golpes que desferem no povo há gerações, persistem em humilhar. A própria situação de governante e governado já é manifestação de uma cisão, de uma dominação em nome de outras várias dominações que se servem desta. Madalena se lembra do prefeito que xingava e fazia pouco caso quando ela e outros companheiros de comunidade iam lá reivindicar.

Eu mesmo ouvi o relato de uma participante de CEBs contando sobre a forma como um prefeito de Santo André as tratava. Numa ocasião, esta companheira junto com mais duas foram à prefeitura, tendo reunião agendada com o prefeito por conta de uma reivindicação do bairro. Elas chegaram no horário marcado, mas ele não vinha atendê-las. Passou-se mais de uma hora do horário combinado. Até que foram recebidas. Sentado, ele colocou os pés sobre a mesa e disse:

- Sejam rápidas, porque os vossos maridos estão trabalhando e quando chegarem vão querer jantar.

Para esta companheira, o sentimento foi de que ele estava querendo dar a entender que elas não tinham o que fazer ali e que deveriam estar em casa.

Assim, um governante marcava nas lembranças de alguém uma maneira de tratar os mais pobres e, sobretudo, as mulheres pobres. Cada uma delas sentiu o golpe que as 
humilhava por pertencerem a um grupo da sociedade tanto tempo rebaixado por outros grupos dominadores.

Os que exercem dominação e reforçam as divisões da sociedade esperam que os humilhados simplesmente se submetam e aguentem quietos seus sofrimentos. Mas a reação sempre vem. E para os moradores da região da São Geraldo, organizados em grupos como as CEBs e outros, a vontade dos poderosos é desobedecida. Seus admiráveis atrevimentos criam dificuldades à dominação e, ao mesmo tempo, o povo ergue sua dignidade com as próprias mãos.

"Quando a gente anotava tudo isso, ia para a prefeitura. E lá a gente aproveitava o plenário. Quando tinha sessão, entrava todo mundo. Aí, eles tinham que ouvir a gente, porque era muita gente mesmo, sabe, muita.

Tudo saía daqui. A gente arrumava carro, ia a pé, dava um jeito. Quem estava lá no Centro trabalhando já ia de lá. E daí a gente escolhia - era tudo organizado -, uma pessoa para falar, a pessoa para reivindicar. E combinava os gritos de guerra para gritar, para falar". (Madalena)

Queriam impedir os pobres de participarem da vida pública, escondendo-os nas periferias, golpeando-os com xingamentos ou com descaso. Queriam-nos invisíveis, sem voz. Mas aí mesmo é que os pobres surgiam como aparições surpreendentes na cidade, fazendo marchas pelas ruas, reunindo vozes numa entonação política, porque visando a participação no governo da própria vida. Por isso, o pobre usa da astúcia, não para criar novas dominações, mas para superá-las em favor de todos.

Essas respostas à humilhação social, encaradas coletivamente, promoviam também o remédio individual. Compreensível esse acoplamento dos sofrimentos com as respostas a eles. A lembrança da ferida se torna mais possível porque não ficou sem um remédio.

Mas os enfrentamentos aos golpes da dominação é que os entusiasmam. Quando perguntei sobre as greves, Madalena sorriu gostoso, sua voz virou um hino de prazer: "Eita! As greves eu lembro". Que beleza esse "eita", que sabor de alegria. Ela vivencia uma satisfação saudosa, tão desejada para o presente. Da mesma maneira, Messias lembra, deliciando-se, do dia em que desceram mais de 200 pessoas a pé do morro e foram ao Semasa, sendo finalmente atendidas na reivindicação de tantos anos. "Ah, que coisa mais linda, sabe!..." A memória suscita sentimentos, traz para o presente um gosto do passado que alicerça a esperança nos banquetes do futuro. 
Como atina Ecléa Bosi (2003, p. 208): “As chaves do futuro e de utopia estão escondidas, quem sabe, na memória das lutas, nas histórias dos simples, nas lembranças dos velhos".

\subsubsection{Lutas}

As lutas do povo nasciam de necessidades concretas. As transformações das condições de vida vinculam-se diretamente às carências que surgem. Num contexto mais amplo, as mudanças sociais, econômicas, culturais, que os impeliram às migrações. Logo, as ocupações de terrenos foram a alternativa dos despossuídos. A incorporação cada vez maior das mulheres em trabalhos fora de casa vai gerando necessidades como a das creches. E para cada uma das rupturas no modo de vida antecedente, abre-se uma nova série de dificuldades para o povo.

As memórias se referem muito a um período em que o crescimento de grandes centros urbanos se dá em termos de marcante desigualdade na distribuição de benfeitorias urbanas e dos equipamentos de consumo coletivo. A urbanização por expansão das periferias, acompanhada pelas respostas bastante precárias do Poder Público em relação às demandas de uma parcela de moradores inseridos nas metrópoles por uma via subalterna, configura um processo espoliativo (cf. JACOBI; NUNES, 1982). Nesse contexto, os narradores lembram e refletem sobre suas condições de vida.

A ausência de ônibus para subir da Vila Humaitá para casa era um dos problemas. Mas mesmo em locais inseridos no itinerário, dependendo dos horários, os ônibus tampouco passavam. Voltar para casa depois de um dia de trabalho podia levar horas.

Conseguir água nas casas também era difícil. Boa parte dos bairros da Paróquia São Geraldo ficam em locais altos. E o abastecimento de água se dava nas piores condições. As pessoas precisavam encher os baldes de madrugada, antes de acabar o fornecimento. E, muitas vezes, a água se esgotava nas regiões baixas antes de chegar ao alto. E luz e asfalto e moradia... Muitas foram as dificuldades enfrentadas pelo povo.

Os problemas do bairro, como a falta de luz e de água, atestam uma cidade dividida entre centro e periferia. É a dominação se explicitando no espaço. As condições de deslocamento via transporte público explicitam a divisão que rebaixa a peças de máquina os trabalhadores e os pobres em geral. Todos os que precisam de condução pública para se deslocar são submetidos a condições massacrantes. Os bens públicos são praticamente inacessíveis, e o pouco acesso que conseguem se dá em condições precárias e se impõe como 
favor. Mas o olhar das pessoas que sofrem tais condições, a partir das memórias aqui narradas, não se apresenta nem submisso, nem conformado.

Mesmo em um bairro com tantas carências, um condomínio de habitações para abastados foi construído e depois abandonado. Os narradores lembram esse fato com um tom de afronta e de injustiça.

O parque lhes é negado também. No bairro dos pobres não caberia um espaço de lazer, mas somente um aterro sanitário, que sabiamente os moradores fazem questão de desvendar chamando com outro nome: "lixão". Nesse caso, o nome que se dá não é ingênuo, mas fruto de uma consciência e de uma resposta.

Mas, nestas memórias, as afrontas são lembradas junto com os enfrentamentos. As lutas são algumas das memórias mais compartilhadas pelo grupo. Cada narrador vai construindo, em mutirão, a morada destas memórias tipicamente coletivas, bastante recorrentes entre as pessoas da mesma região (cf. HALBWACHS, 2004). Cada ponto de vista sobre os mesmos fatos conserva semelhanças e se apóia nas lembranças dos outros. Cada narração enriquece a compreensão geral que o grupo tem a respeito das situações vividas.

A ocupação do Centreville ${ }^{9}$ é contada por Margarida combinando a captação da atmosfera passada, a síntese de relatos sobre o fato e as lembranças das ações desenvolvidas pelo companheiro de CEBs.

"Perseu pegou - foi logo quando começou as CEBs -, aí o Perseu chegou, combinou com todo o mundo, falou assim: 'Hoje de noite, a gente vai atabafar o Centreville. Cada pessoa vai entrar numa casa e não vai sair'. Aí, juntou gente pra caramba, viu. Aí, fomos tudo a pé para o Centreville. No Centreville era tudo fechado. Não tinha moradia, não tinha nada e nem eles abriam mão. Aí, o Perseu vai, na hora que estava todo mundo preparado lá no Centreville - gente pra caramba! -, aí ele fala: 'Agora vamos invadir'. Aí, começaram a abrir as casas, e com pontapé e tudo, e cada qual entrava. Até hoje”. (Margarida)

Nas lembranças das ações para impedir os ônibus de circularem, os narradores convivem com a certeza de terem feito algo bom junto com os dilemas de usarem métodos mais duros. Essas ações carregam a tensão moral presente na luta. Messias narra já com a compreensão decantada pelos anos. Afinal, existem contradições nas conjunturas que fazem com que as intervenções para construir uma sociedade melhor passem por uma diversidade de

\footnotetext{
${ }^{9}$ Desde o início da década de 70, estava em andamento a construção de um condomínio de médio e alto padrão na região. A empresa responsável, financiada por empréstimo público, paralisou as obras em 1976 sem concluir o projeto. Abandonadas, as casas foram ocupadas por famílias em 16 de julho de 1982, numa ação articulada pelo PC do B e contando com a participação de pessoas ligadas a movimentos eclesiais, sindicatos, Sociedades de Amigos de Bairros etc. Uma nova ação de ocupação aconteceu no ano seguinte, somando mais de 500 casas no total.
} 
fatores que comumente formam obstáculos, tais como: as pressões para os trabalhadores furarem as greves, as diferentes adesões e níveis de consciência sobre as circunstâncias. Assim, a intervenção precisa lidar com as dificuldades em cada momento. Messias tem um olhar compreensivo sobre as tensões com as quais teve que lidar. Ameniza a tensão moral e descreve a ação:

"Então, a gente ajudou muito a parar esses ônibus, de uma forma não muito legal. (risos) A gente levantava muito cedo mesmo, quando os ônibus começavam a trabalhar, para eles não saírem da garagem". (Messias)

João, ao lembrar, avalia de forma mais enfática o método de impedir os ônibus. Diz que "era uma coisa que não era certa". Mas essa tensão não é resolvida simplesmente condenando as ações realizadas. Não. Isso seria simplismo idealista. Afinal, o povo lidava com condições conflitantes. Às vezes, tinham que ir ao limite de suas adesões morais. Por isso, João completa sua avaliação com a indicação das contradições reais: "Na época, era uma coisa que não era certa, mas que tinha que fazer. Tinha que apelar. Porque os ônibus levavam os trabalhadores para as fábricas. Então nós não deixávamos circular para a turma não ir para a fábrica, para ficar todo mundo em casa".

Nos critérios de valores ligados à promoção da vida, a efetividade da greve tinha mais peso do que o problema moral dos impedimentos à circulação dos ônibus. Apesar de essa tensão não desaparecer nas narrativas memoriais, ela explicita uma certa hierarquia de valores que, no meio das contradições, dá subsídios para fazer escolhas.

Decidir entre dilemas de tensão moral envolve o aprendizado e o reforço da capacidade sagrada de desobedecer. Erich Fromm (1984) identifica na dominação a vinculação ideológica da obediência à virtude e da desobediência ao pecado:

[...] Até aqui, ao longo da maior parte da história, uma minoria dominou uma maioria. Essa dominação se tornou necessária pelo fato de que só havia o bastante das boas coisas da vida para uns poucos, restando apenas migalhas para os muito numerosos. Caso a minoria quisesse desfrutar das coisas boas e além disso, ter a maioria para servi-la e trabalhar para ela, uma condição se fazia necessária: a maioria teria de aprender a obedecer. (p. 16).

Essa obediência se enraizou no coração das pessoas ao longo de gerações, aparecendo como virtude. Porém, o desvendamento da dominação também veio acompanhado de desobediências imprescindíveis ao avanço da sociedade. Cada participante de CEBs e de 
grupos afins demonstra que, apesar da tensão moral presente nas ações políticas, uma estrutura de valores deu bases para desafiar os elementos morais vigentes e os grupos e pessoas que personificam a dominação. Eis uma grande esperança possível de se entrever na vida destas pessoas: a capacidade de rompimento pela desobediência. Talvez, isso seja parte fundamental da nossa salvação frente à capacidade destrutiva incomparável que a sociedade do capital alcançou em seu desenvolvimento.

O homem da organização perdeu a capacidade de desobedecer e nem sequer tem consciência do fato de que obedece. Nesse ponto da história, a capacidade de duvidar, de criticar e de desobedecer talvez seja tudo o que se coloca entre o futuro da humanidade e o término da civilização. (FROMM, 1984, p. 17).

Outro aspecto ligado à memória das lutas é a descrição da organização do povo. As lembranças marcam uma conquista: a possibilidade aprendida de se organizar. Os abaixoassinados; as estratégias de ir à prefeitura sem avisar, a fim de pegarem as autoridades de surpresa e não serem impedidos de protestar; as tarefas para marcar os intervalos entre os ônibus, extremamente organizadas em turnos de pessoas desde a madrugada; as reuniões para planejar o parque e impedir de transformá-lo em lixão; os protestos pela água, levando símbolos da precariedade às sessões da Câmara; as reivindicações pela creche, escolhendo uma mulher para fazer a fala; a preparação de gritos de guerra; os convites para a participação nas ações, indo de casa em casa; a articulação prévia com eventuais aliados da gestão pública para facilitar o acesso às autoridades; etc.

Ao lembrarem e descreverem os processos para se organizarem, os narradores revelam o quanto se convenceram da importância de unirem esforços. Eles se enchem de entusiasmo ao lembrarem a força do povo em movimento.

Outra certeza que aparece nas memórias é a da vinculação entre as lutas e as conquistas. Nada fica alheio às ações desencadeadas pelo povo. Nada é visto como favor ou como melhoria que chega de instâncias governamentais, vindas de cima pra baixo. A cada lembrança das lutas, também a lembrança do que alcançaram: instalação de estrutura para levar água aos morros, normatização dos preços e da regularidade de circulação dos ônibus, asfaltamento, instalação de creches e de postos de saúde, manutenção das ocupações, entre outras. As conquistas são como frutos de um pomar bem cultivado, adoçado também com o suor e esforço de seus plantadores. "O pouco... um centavo, dois, três que diminuiu na 
passagem, foi uma vitória. Foi um fruto do nosso trabalho, da luta". (João) "Essa caixa d'água que tem aqui. Tudo aqui foi conquista mesmo desse povo daqui, dessa igreja, das CEBs. Foi bom". (Madalena)

A memória revela aí uma função muito importante: confirmar o movimento da realidade. As lutas lembradas contribuem para a superação da naturalização, da sensação de ter condições imutáveis, do presentismo ${ }^{10}$ que não considera o devir da realidade. Ao lembrar, conseguem enxergar condição para a mudança e constatam o resultado de suas lutas. Apropriam-se, assim, da história. Ao refletir sobre as lutas e conquistas que relatam, podem chegar a conclusões como a de Messias quando lembra das caixas d'água que, finalmente, foram instaladas: "Não valeu? Valeu o movimento".

\subsubsection{Luta e repressão}

Parte das lembranças relacionadas às lutas também traz junto os golpes da repressão, a atmosfera de vigilância, a proximidade da violência, o medo. Margarida nos rodeia de presenças hostis ao contar:

“A gente também não podia abrir muito a boca, né, Gustavo. Não podia abrir muito a boca porque eles ficam tudo com os 'olhão' assim, com os 'ouvidão' abertos, sabe, os políticos. Ficavam tudo com os 'ouvidão' abertos a respeito desse negócio. As CEBs chicoteou muito os políticos, sabe".

Essa atmosfera emanava perigo. Os "olhão" e os "ouvidão" pontilhando as ruas, as casas, as paredes, as relações. Traição e caçada, duas formas de aparição iminentes. O mínimo descuido era suficiente para ser pego e, muitas vezes, ser desaparecido. Messias lembra que muitos amigos nunca mais foram vistos. As manifestações eram audaciosas. Os gritos do povo vibravam e os cassetetes latejavam prestes à agressão. Clandestinamente, os grupos como a JOC se organizavam para combater a ditadura. Reuniões de madrugada, locais escondidos, pichações arriscadíssimas, precaução com fotografias, distribuição noturna de panfletos. A memória vai percorrendo a experiência passada e o medo vivido. Não bastava desafiar o sistema social, era preciso desafiar também as próprias emoções, que frequentemente chegavam ao limite. Quando a iminência da dor física se aproximava demais,

\footnotetext{
${ }^{10} \mathrm{O}$ termo presentismo me parece bastante interessante e se deve, aqui, à reflexão do psicólogo social Nicolás Farfán, remetendo-se também a Martín-Baró. O comportamento do presentismo reduz o horizonte de vida ao presente. Ao negar tanto o potencial criador da história quanto da memória social, nega-se também a condição de sujeitos sociais das pessoas. Impondo a noção de um cotidiano acachapante e de uma suposta inevitabilidade da situação presente, fomenta-se a ilusão de que nada muda. A valorização da memória social é, portanto, antagônica ao comportamento alienante do presentismo (cf. FARFÁN, 2010).
} 
a energia se concentrava toda na fuga, tão constante entre os que ousavam lutar em tempos ditatoriais. Fugir, correr, correr, correr. Lembranças detalhadas, momento marcante.

Podia ser uma fuga em missa campal do $1^{\circ}$ de Maio. Com Geraldo Vandré, Trio Marayá, militantes, padres, e um estopim pra começar a paulera.

“De repente... o pelotão de choque apareceu... Mas foi uma correria! O padre Mahon correu para a casa do bispo e nós corremos atrás do padre, o Geraldo Vandré e o Trio Marayá, tudo para a casa do bispo. Era o Dom Jorge naquela época. Nós ficamos um tempo lá.

[...]

Quando nós olhamos - eu e minha amiga -, vimos o padre correndo para a casa do bispo, nós falamos: ‘Ah, é pra lá que nós vamos’. (risos) Não vou apanhar, nada. Tá louco! Dói pra caramba. (risos) Eu não gosto de dor. Não suporto dor. Mas os nossos amigos eles pegaram. A gente nunca mais viu a cara deles...”. (Messias)

Poder lembrar sem as marcas da tortura, dos hematomas de pancadas no meio da praça, é um grande alívio. Mas a adrenalina volta ao hálito de uma conversa mais de 40 anos depois.

No final dos anos 60, sobreviver e temer podiam andar tão próximos que mal cabia espaço para algo mais. Porém, espremida no meio estava lá, cutucando o temor: a convicção. Esta, que impulsionava tantos à ação política. De baque em baque, seguiam se reunindo para se contrapor ao regime autoritário. Era preciso muita convicção para suportar as exigências. Como disse certa vez Leonardo Boff numa entrevista concedida para um documentário sobre Dom Hélder Câmara, o profeta não pode ter muito amor ao próprio pescoço.

"Uma vez eu fui numa reunião do Monsenhor, ali na Príncipe de Gales. A reunião foi na casa dele. Mas quando estavam sentando todos os jovens para se reunir... a polícia. Nossa! O padre abriu a porta do fundo e todo mundo ó... Meu Deus do Céu! No meio daquele mato, daquela cerca, sumimos, nem sei onde foi, nem lembro onde foi. Que a gente correu, correu, correu, mas eles não pegaram a gente, não. Mas aí... (risos) Aí fugimos”. (Messias)

Os jovens, que se dispersaram no meio do mato denso, ficaram horas esperando para voltar pra casa. Era assim. Na Igreja, aqueles que identificavam a missão cristã com a luta de libertação do povo arriscavam-se profeticamente. Entre os sofrimentos da vida em condições precárias se juntava o sofrimento da repressão. A insistência nos enfrentamentos, mesmo sob condições tão adversas, pode ser considerada como uma das principais respostas. Quando há riscos apontados por todos os lados contra o peito de quem protesta, continuar a luta é uma das respostas mais eloquentes. 
"Olha, foi uma fase assim de... sei lá... acho que foi uma grandeza muito grande, porque você desafia. É um desafio, né. Desafia, porque... o medo, as estruturas. Que era uma estrutura montada, muito repressiva. Você não tinha direito a nada. Você andava na rua, se não tomasse cuidado, você levava cacetada. Era preso e sumia”. (Messias)

Seguem-se os anos e se desenvolve, articulado a estes movimentos de luta, o novo sindicalismo. As disputas entre trabalhadores e patrões massificam-se. As grandes greves entre o final dos anos 70 e início dos 80 mobilizam o ABC. E lá estão os cristãos, engajados desde o final dos anos 50 num germe de projeto sindical mais atuante, aberto, democrático e participativo a partir da base (cf. MARTINS, 1994).

É interessante que a memória revela a concretude da inserção cristã no espaço sindical. Se havia os que se engajavam nas lutas trabalhistas com uma densa consciência de classe amadurecida ao longo do movimento operário, havia também os que foram sendo formados ao longo das grandes greves entre 78 e 80, já sob a liderança de Lula. Formação que podia se dar, em parte, no choque com a realidade da repressão, nas posteriores críticas e comparações feitas entre sindicatos, na percepção ainda em gestação da polarização entre os aparatos dos patrões e os aparatos da classe trabalhadora. A repressão policial, por exemplo, ao se voltar contra os manifestantes grevistas, orientava a consciência de João para o questionamento em relação ao lado em que o Estado se posicionava. Para ele, as críticas ao governador da época, Paulo Maluf, não são abstratas, mas concretas. Ele sentiu na pele um pouco do que aquele governo e seu governador faziam efetivamente em relação ao povo em movimento. E mais uma vez, a lembrança da luta se mescla à lembrança do medo e da fuga.

"E aí, a polícia chegou com aqueles caminhões de choque. Não sei se você lembra... Você se lembra daqueles caminhões do choque que tinha antes? Chegaram acho que quatro caminhões. Tudo com soldado, e cada um com um cachorro. Rapaz! Soltaram no meio daquela peãozada! Mordia a peãozada e tacavam bomba lacrimogênio no meio. Eu já estava mais para a frente um pouquinho, a hora que eu vi que a polícia começou a bater, eu já saí correndo. Mas, rapaz, eu corri, corri, corri, e o cachorro atrás, o cara tacando bomba, aquela fumaça, o olho ardendo. Um policial tacou uma daquelas bombas lacrimogênicas, ela passou correndo por mim, assim, e estourou na frente. Eu passei no meio da fumaça. Arde muito o olho. E atravessei a Goiás que eu nem olhei pros lados. A Goiás era estreita, né. Se tivesse vindo carro me atropelava, por causa de tanto medo. De tanto medo... E cachorro correndo atrás. O cachorro parou, aí voltou, atravessou. E o policial voltou com o cachorro. Mas mordeu colega meu. Olha, foi uma covardia”. (João) 
Quebra-se, aí, uma espécie de inocência de João em relação à luta de classes. Sua narrativa indica um salto de visão sobre a realidade. A perplexidade se contorce para entender o porquê da violência contra a greve pacífica, o porquê da própria greve, o porquê de ter sido organizada sem participação, qual o papel do sindicato. Lembrando a confusão que sentiu por esse choque, ele evoca a instauração de um movimento mais radical em sua própria consciência.

"Ninguém estava fazendo nada, não tinha encrenca, era pacífico. A maioria estava lá de bobo, igual eu. Não sabia de nada. O sindicato lá de São Caetano sempre foi pelego, sempre foi sem-vergonha. Até hoje ainda é do lado do patrão. Fazia os acordos com o patrão. Enganava o peão. Aí, eu fui embora aquele dia. Disseram que não ia abrir.

\section{$[\ldots]$}

Se tinha um sindicato que era pelegão lá, de São Caetano, que não valia nada, mas tinha um povo lá que queria alguma coisa. Queria uma melhoria lá dentro. E aí acabou, ficamos uns dias de greve. Nós acabamos perdendo a greve lá ainda. É fogo, a gente não sabia de nada... (risos) Eu não sabia nem o que era greve direito. (risos)

Eu contava para o pessoal nas CEBs. Eu contava o que aconteceu. Que o governador mandou a polícia lá e desceu o pau na turma. Todo mundo, os coitados, ninguém estava agitando. E foi falado que era tudo agitador. Por isso é que desceram o pau, foi falado. Não tinha ninguém, os coitados, os caras todos trabalhadores! Aquele pessoal enganado, igual eu fui lá. Que o sindicato chegava lá, fazia aquele barulho todo, e aliado com o patrão. Já preparando para mandar a turma embora logo". (João)

Depois de todos as anos de formação e participação, João faz a avaliação da situação e do sindicato combinando com a reconstrução do que sentiu e viveu à época. $O$ frescor da inocência e a consciência crítica acerca do vivido se mesclam. Aqui, a lembrança do sofrimento é acompanhada de uma resposta já bem posterior ao golpe. Pensar sobre o assunto com tom crítico é responder a ele, é elaborar o tratamento da ferida que à época ficou exposta. Para João, o peso da repressão caiu abruptamente sobre si. Abriu rachaduras em sua consciência que lhe serviram de brecha para questionar radicalmente o contexto que viveu. Tomar consciência como forma de ofertar dignidade ao choque.

Como diria Riobaldo: “Ah, para o prazer e para ser feliz, é que é preciso a gente saber tudo, formar alma, na consciência; para penar, não se carece: bicho tem dor, e sofre sem saber mais porque." (ROSA, 2001, p. 328).

Assim, o sofrer se humanizou na vida de quem soube o sofrido da repressão. 


\subsubsection{Iniciativas}

A experiência das dificuldades, cada vez mais passou a ser encarada como problema coletivo. As brigas entre vizinhos começaram a ser substituídas pelos laços de amizade e cooperação. Aos poucos, avançaram em direção a uma consciência marcada pela constatação de suas condições semelhantes e pela perspectiva de que só podem se libertar juntos. No lugar da guerra entre vizinhos, aparecem as iniciativas para tomar as rédeas da situação e construir uma condição mais favorável.

Fazem mutirões, decidem onde haverá praças, organizam sacolão, preparam festas nas ruas, realizam trabalhos de geração de renda cooperativos, planejam a segurança do parque. Algumas das iniciativas revelam uma abrangência considerável. É o caso do que relata Messias, sobre as muitas iniciativas voltadas para as crianças e famílias da região. Ela mesma liderou as mães para levar médicos e psicólogos à escola, começar um trabalho muito organizado de atletismo, inserir a educação sexual, montar grupo de teatro. Com as famílias, trazia terapia, formações, entre outras iniciativas. Muito interessante é a união das mães para educar coletivamente as crianças. Ali, os filhos não eram educados somente pela família nuclear, mas pela comunidade.

"E foi pensando nisso que a gente reuniu um grupo de mulheres que tinham a mesma visão, e que a gente começou a se unir e começamos a trabalhar juntas. A gente batia corda para as crianças, ensinamos elas a brincarem, a respeitar o outro, a se educar. A gente pulava amarelinha, brincava de alerta. Ficava brincando até nove horas na rua. Todas as mães ajudavam. Começaram a participar”. (Messias)

Ao vincular memória das dificuldades e memória das conquistas, pela mediação das lutas e iniciativas, mais uma vez brilha na narrativa memorial a noção do devir das situações a partir das intervenções humanas.

"E aí, era até gostoso, porque as mães começaram a entrar. Aí, todas as mães da rua começaram a participar. Acabaram as brigas”. (Messias)

E a intervenção ativa do povo no seu próprio destino abre a cada participante um ganho na sua condição particular. Aproximam-se das potencialidades que somente socialmente podem alcançar. Acima do isolamento, cada um dos lutadores do povo se torna mais indivíduo, e mais humano. Mostram que indivíduo e sociedade podem se reconciliar, gerando ganhos para ambas as instâncias. 
Quanto mais o indivíduo é capaz de 'reproduzir-se como indivíduo social', menos intenso é o conflito entre indivíduo e sociedade, entre indivíduo e humanidade - isto é, nas palavras de Marx, menos intenso é 'o conflito entre existência e essência, entre liberdade e necessidade, entre indivíduo e gênero'. Mas o indivíduo não se pode reproduzir como indivíduo social, a menos que participe de maneira cada vez mais ativa na determinação de todos os aspectos de sua própria vida, desde as preocupações mais imediatas até as mais amplas questões gerais de política, organização socioeconômica e cultura. (MÉSZÁROS, 2006, p. 259).

A participação do povo na construção de seu destino passa necessariamente pela desalienação de seus poderes para autodeterminar sua vida. Quando decidem sobre as áreas de lazer de sua região, quando influenciam diretamente o arranjo escolar de onde seus filhos estão matriculados, quando conhecem cada um dos problemas dos bairros e tomam medidas diretas baseadas na interação de cada um dos participantes, caracterizando ações políticas autenticamente originadas na base, então as pessoas participam diretamente das determinações de suas vidas. Reciprocamente, constroem uma direção que é fruto de cada um, reunidos num “nós” participativo. Qual o impacto desta participação? Como cada pessoa, em processos de interação e de ações como estas, passa a lidar subjetiva e objetivamente com a realidade? As mobilizações narradas com entusiasmo não teriam o sentido da vitória em benefício das comunidades e também o sentido de uma elevação na própria individualidade?

"Então, a gente vai aprendendo, nas Comunidades Eclesiais de Base, a não ser explorado, a viver uma vida digna, a viver não só para a gente, mas para o seu próximo, para a pessoa que está do lado”. (João)

Reconhecem no próximo, naquele que está ao lado, um companheiro em devir, uma potencialidade humana em avanço.

Aqui, é quase impossível as pessoas se perderem no turbilhão capitalista do individualismo. A participação nestas lutas vai antecipando os indivíduos sociais, aqueles que colocam suas personalidades e iniciativas em interação de reciprocidade com as personalidades e iniciativas de outros (cf. MÉSZÁROS, 2006).

"Mas a experiência de vida é muito gratificante, porque você aprende a se doar, você aprende a conviver com as pessoas, você aprende a respeitar o limite dos outros, você aprende realmente a conviver em sociedade. Porque tudo você tem que trabalhar em grupo. Então, não é o que 'eu' acho, é o que 'nós' achamos, o que ‘nós' pensamos. O que é melhor para todos”. (Messias) 
Estas palavras são frutos de uma participação. É com baldes nas mãos, panelas tinindo pelas ruas, olhos nos olhos dos poderosos, voz com volume de profecia nos cantos entoados e um Jesus dos marginalizados no coração que os narradores se compreendem como pessoa, como povo.

"Na verdade, quando você começa a lutar, querer uma mudança, tudo isso gera política. Vai gerando. Mas eu nunca tive problemas com isso, não. Foi uma coisa boa. Eu achei que foram boas essas duas coisas na caminhada juntas. Porque senão hoje eu não teria essa cabeça que eu tenho agora". (Madalena)

E qual é a cabeça que Madalena, Messias, João, Margarida, Natalina, padre Mahon, Alice e tantos outros têm agora? A caminhada de participação nas lutas e iniciativas, o enfrentamento dos sofrimentos e o olhar totalizante sobre a realidade confirmam a resposta. Suas vidas, suas cabeças. 


\subsection{Figuras de referência}

Povoam as narrativas pessoas que foram e têm sido referências para os que lembram. Pessoas que contribuíram para formar quem, hoje, nossos narradores são. Pessoas que escreveram histórias em pessoas. Quantas pessoas cabem dentro da gente! Faz-se presente a indagação que Riobaldo forma acerca da possibilidade de vender a alma. Quando ele ia relembrando tantas gentes de sua vida, indaga: "Tudo isso posso vender? Se vendo minha alma, estou vendendo também os outros." (ROSA, 2001, p. 327). Nossos narradores confirmam.

Há figuras históricas, como Lula, que em algumas memórias é colocado como referencial de tempo. Na dúvida sobre a precisão de alguma data, ele é evocado para marcar um período. "Nessa última greve que houve, foi uma greve bem forte, que a Volks parou. Não lembro mais o ano... Acho que foi em 79. Foi quando o Lula estava na liderança. Foi mais ou menos nessa época que a gente fez". (Messias)

Dentre as figuras históricas, algumas aparecem mais próximas. É o caso de bispos, por exemplo. Para João, Dom Cláudio Hummes, aquele que acolheu os trabalhadores em fuga da polícia, depois se torna um ilustre amigo.

O prefeito assassinado, Celso Daniel, é lembrado em contatos pessoais desde antes de se tornar bem conhecido. Foi companheiro de militância na luta do transporte público. As reuniões com ele são lembradas. Depois, já como candidato por quem fizeram campanha. Ele se torna prefeito e as lembranças inserem a contradição entre admiração e, por vezes, as críticas. Por fim, a referência ao antigo companheiro de militância e posterior prefeito traz a distância do monumento: torna-se nome do parque. Porém, o nome do parque, para os narradores, remete não somente ao antigo prefeito, mas também à lembrança cálida da pessoa com quem conviveram.

Mas as principais referências são as de pessoas que habitam na alma de outra maneira, bem mais aconchegadas. Estão lá ativas, com a voz, a pele, as risadas, o exemplo. Sentados no chão para comer uma refeição, fazendo convites para participação, contando um sonho, sendo presos junto com o povo, tratando de uma doente, propondo ações, discutindo ideias, chegando para uma visita, voltando junto pelas ladeiras da noite, vivos. Não só vivos: fazendo viver.

Quem habita as vidas dos narradores, em geral, conviveu em momentos diversos, compartilhou situações pequenas e grandes. Quando os narradores evocam suas presenças, 
acabam também revelando a si mesmos, pois a substância de que são feitos já digeriu a comunhão destes encontros.

Podem ser os pais. Os de João mostraram, com seus gestos, que nem a pobreza nem a fragilidade de uma filha doente são empecilhos para o amor. Pelo contrário. Levar ao médico, tratar bem, dar banho todo dia, cuidar, trocar a cama, trocar a roupa. Cada gesto anuncia algo: a importância da vida, seja lá em que condição se encontrar. É reconhecida a doação dos pais pobres, que davam o pouco que tinham mesmo que não tivessem quase nada. "Mas quando o pai pegava, só faltava dar o coração para a gente, de tão bom que ele era. Minha mãe... a gente ficava sem nada porque não tinha, o meu pai também não tinha. Era uma vida pobre”. (João) Depois, ungido com esses exemplos, João passou a cuidar dos pais. Suas lembranças indicam a tonalidade dessa referência familiar: "Era uma vida pobre, que nós vivíamos e sempre vivemos, mas que tinha uma riqueza em amor". (João)

Os pais também podem ser lembrados como companheiros. Companhia certa nas caminhadas de CEBs, como a mãe de João. Amigo absolutamente confiável em meio à repressão da ditadura, como o pai de Messias.

“O meu pai pegava todos os panfletos. A minha parte, ele distribuía. Ele punha uma capa de chuva - eu nunca esqueço (risos) -, ele enchia os bolsos de panfletos e ficava na estação. Escondidinho lá, passando os panfletos. O meu pai achava legal as coisas que eu... Ele dava ênfase. Ele me apoiava”. (Messias)

Era o pai pobre mas que lia muito, a mãe que acolhia, pai e mãe que participavam junto. Pais e mães que antecipavam valores que seriam confirmados e desenvolvidos pelos filhos nos grupos de que fizeram parte. Madalena liga suas principais experiências de grupo com a mãe:

"Sou CEBs desde pequenininha. Sem saber. Mas eu falei pra você da minha mãe, né. Minha mãe era muito, nossa... minha mãe era muito generosa. Ela recebia, acolhia muitas pessoas na minha casa. Muitas. Sempre viveu, assim, essa 'Porta Aberta'”. (Madalena)

Juan Luis Segundo (1997) realça a importância dos testemunhos pessoais para escolher nossos valores. Diante da incerteza sobre a realização de felicidade que cada adesão a valores absolutos - aqueles que guiam nossas vidas e que dão diretrizes a todos os valores secundários - pode oferecer, temos que confiar nas pessoas que vivem ou viveram esses 
valores. Elas são para nós os testemunhos de que certas adesões valem a pena. Apostamos nossas vidas numa história semelhante à daqueles em quem confiamos, em quem temos fé ${ }^{11}$.

Aos poucos, alguém pode ir admirando outrem. Repara nos gestos simples mas cheios de positividade. Percebe que a outra pessoa convoca, anima, orienta. Essa admiração pode ir abrindo espaço para uma confiança de que o outro vive uma vida em direção à felicidade e ao sentido. Será que vale apostar nessa direção também? E alguém vai tateando, em suas práticas, os valores que começa a amar.

"Eu fico pensando que eu tinha uma vizinha, ela tinha bastante criança. Mas aquelas meninas eram cheias de piolho, sabe, as crianças. Daí, sempre a dona Margarida: 'Fazer o gesto concreto, temos que fazer um gesto concreto'. Daí eu falava assim: 'Ah, eu vou catar os piolhos das meninas da... - esqueci o nome dela agora... - porque isso é gesto concreto, né, dona Margarida?"”. (Madalena)

A aposta naquele caminho de felicidade, naquela estrutura de valores, parece se confirmar aos poucos. Vê o resultado dos apoios dados à vizinha. Reencontra-a cheia de vida. E confirma ainda mais que aquele caminho faz outros felizes, o testemunho no qual confiou traz vida aos outros. Provavelmente, também traz vida a quem espalhou as sementes. Madalena passa a sentir que aquele testemunho é realmente muito confiável. Testemunho de quem mudou a vida das pessoas com seus gestos concretos. E deseja que todos pudessem ter contato com dona Margarida, que se lhe reafirmou como fonte de referências fundamentais.

“Eu falei assim: 'tá vendo a diferença que as pessoas fazem na vida do outro, né'. Sempre falo: 'Todo mundo deveria ter uma dona Margarida na sua vida'”. (Madalena)

As testemunhas referenciais "de mil maneiras (a maioria delas não explícitas), falamlhe da satisfação que traz consigo a realização desse ou daquele valor e, com essas mesmas vozes mudas, convidam-no a seguir um caminho semelhante". (SEGUNDO, 1997, p.17, grifo nosso).

São mesmo mudos e estrondosos os testemunhos. Mas a voz que estronda passa silenciosamente pelos pequenos gestos de coerência, pela expressão corporal convincente, por um modo de encarar as situações movido por esperança, pelo jeito de viver. Eu me lembro bem que numa tarde fria conheci uma velha freira. Era uma exposição sobre Mário de Andrade e eu trabalhava lá. Ela estava com uma companheira de congregação, as duas sentadas assistindo a um raro vídeo com imagens captadas do artista. A freira sorria, como

\footnotetext{
${ }^{11}$ Aqui, a fé está sendo tomada, mais uma vez, no sentido antropológico. Ou seja, como estrutura de valores à qual aderimos baseados em testemunhas, apostando na felicidade e no sentido individual e coletivo que se poderá alcançar nesta direção. Um dever-ser que não necessariamente se apóia na fé religiosa.
} 
que confirmando as imagens que tinha no fundo de si mesma e que agora eram reforçadas pelo vídeo. Contou-me que, quando jovem, fora aluna de Mário de Andrade - aquele que era "assim mesmo como aparece no vídeo" - no Conservatório Musical. E que estava ali na exposição não apenas para prestigiar seu antigo mestre, mas porque se tornara freira por causa dele. Como?

Lembrou-se que era um professor sério mas, diferentemente dos outros, as alunas não tinham medo dele. "Era, sem dúvida, um homem bom". Ela se lembrou que o trabalho final do curso foi indicado às alunas, todas com o mesmo tema. Mas a ela, estranhamente, foi pedido que fizesse uma pesquisa sobre música religiosa. Assim, ela passou alguns dias num convento de religiosas para fazer o estudo de que fora incumbida.

Mas os dias de pesquisa no convento mudaram sua vida. Sentadinha na cadeira da exposição, olhos percorrendo o passado, ela puxou do fundo do coração a reflexão sobre a lembrança com que me presenteava: "E lá, com as freiras daquele convento, eu vi uma solidez de vida que eu nunca tinha encontrado antes em lugar nenhum".

Silenciosamente, sem nenhum chamado explícito, as freiras do convento devem ter dado a conhecer um caminho que vale a pena. Testemunhos silenciosos e cheios de volume.

Ali naquele espaço de exposição alguém esculpia e erguia o sentido de uma vida. Nenhuma palavra abstrata sobre valores, apenas a imagem clara do que o testemunho de vida pode fazer com alguém... por alguém. Do mesmo modo como ela captou algo inexprimível mas palpável em exemplos vívidos de freiras, eu também senti algo muito forte. Ao me contar isso, ela também me deu a oportunidade de conhecer a solidez de vida que pode mover os passos de uma existência.

Certo de que a velha freira tinha entrado na congregação naquela mesma ocasião, ela me refutou: "Não! Ainda dancei muito carnaval. Namorei muito. Fui entrar no convento vários anos depois". E riu. A memória puxou a corda de seu arrebatamento juvenil e lhe trouxe uma vocação para seguir tempos depois.

As pessoas das comunidades da Paróquia São Geraldo são privilegiadas em oferta de exemplos de vida. Nas memórias, quanta gente sendo importante para a adesão de valores de outros. O padre Mahon, sempre presente. Nas visitas, nas lutas, na organização, nos conselhos recebidos. Durante os conflitos, colocava-se ao lado do povo. As pessoas contam que ele apanhou, foi preso. Uma marca forte nas memórias é o fato de ele sofrer as agruras junto.

“Teve um negócio de revolta dos pobres... revolta em favor dos pobres... na época de política, não sei como é que foi. Aí, eles pegaram e prenderam o padre José Mahon. E chegou 
a ir para a cadeia. E ele nem ligou. Só falou: 'Estou aqui de peito e coragem. Vou fazer o que eu quiser'. Ali tem fé". (Margarida)

Padecer com o povo, assumir corajosamente as lutas, é prova de fé. É testemunho. Assim, as memórias vão indicando a confiança que tinham no padre Mahon.

"Outra luta dos ônibus, também, foi que eles começaram a subir os preços. Aí, o padre Mahon foi em cima. Ele coordenava. O padre Mahon era o cabeça, ele era o coordenador nosso, geral. Ele dava as ideias, ele mostrava. Ele dava a visão. Às vezes, a gente precisava da coisa e ele sentia que nós precisávamos. E então, ele dava a visão: 'Nós temos que fazer isso, isso, isso e isso"”. (João)

Amigo, líder, companheiro: o padre Mahon. Muitos lutaram inspirados por seu exemplo. De tal modo tem sido referência e alimento moral, que Messias fez questão de acrescentar carinhosamente ao final de sua narrativa: "Ofereço essas memórias ao meu amigo padre Mahon".

Um fator muito importante para que as pessoas sejam lembradas como fontes de formação de nossos narradores é a proximidade e a humildade. É a diferença entre o bispo que exigia ser chamado de "Dom" e o outro bispo que subia nas favelas, abraçava todo mundo, visitava as equipes, comia junto.

Algumas palavras também são nutritivas como boas-novas. Alimentam quem ouviu. Prolongam a vida de quem falou, como a Tetê ou a dona Maria. Já faleceram, mas suas vidas seguem em suas palavras.

"Tem até Tetê, que ela fala: 'O pobre vai levantando a cabeça devagarinho... não é com pressa, é devagarinho"”.

"Tinha a dona Maria, ela sempre contava uma história, sabe. Acabava quase que falando daquela pessoa mas, assim, de um outro jeito que dava certo. E ajudava bastante. Era bom”. (Madalena)

Palavras, gestos e testemunhos que, depois, podem ser evocados em muitas memórias saudosas.

O padre Alfredinho é um núcleo de referência que ajuda a reconstruir e organizar as memórias dos narradores. Grande parte dos valores, crenças, significados, adesões que organizam as experiências deles gravita em torno do que aprenderam e partilharam com o padre Alfredinho.

Pessoas como padre Alfredinho, lembradas nestas memórias, carregam e disseminam valores que nunca se perderam totalmente no trajeto da humanidade. Às vezes, são valores desenvolvidos em sociedades antigas, conservaram-se em grupos, em objetivações (escritos, 
narrativas orais etc.) ou até mesmo em indivíduos. Discerníveis como práticas, como formas de vida que, mesmo nos contextos mais desfavoráveis, tiveram alguns preservadores que os transmitem de geração em geração, podendo reacender com força em sociedades e tempos mais propícios (cf. HELLER, 2008).

Quais serão os grupos do passado aos quais correspondem a partilha, a vida comunitária, a austeridade material, a doçura das relações e outros valores presentes na história de padre Alfredinho? Os essênios, os primeiros cristãos, outros?

Esses valores que também foram encontrados entre os flagelados da seca, entre os moradores de rua, entre os favelados.

Se faltava mais alguma coisa para João aderir à estrutura de valores supremos que padre Alfredinho testemunhava, a experiência narrada a seguir deve ter sido de grande peso. Com grande emoção, João conta:

"Ele ia lá em casa... eu tenho uma irmã paralítica. Com 44 anos, ela faleceu. Ele ia lá, ela estava na cama, a mãe pedia para ele abençoar... Ele falou: 'Ela é que tem que me abençoar'. Ele se ajoelhou na frente dela e falou: 'Meu Deus, nossa, como eu estou distante desse ser humano que sofre tanto... dessa santa aqui...'.

E pedia para ela: 'Ó, me dá proteção...', para a minha irmã que nunca andou e nem falou, 'me ajuda, intercede a Deus por mim, para me abençoar em minha caminhada'. Pedia para a minha irmã! E se ajoelhava na cama dela, o padre!”. (João)

Sempre reerguendo as pessoas caídas, sejam animadores, padres, amigos, pessoas de quem ele se tornava amigo nas amarguras da rua. Quantas lembranças de cuidado e atenção para com os outros, publicadas aqui e presentes em toda a região.

Entre as pessoas lembradas como referências de valores que guiam a vida, o padre Alfredinho é exemplar na riqueza de atitudes com que é evocado. Suas atitudes falavam melhor que qualquer discurso.

"Põe a mesa, ele pega aquele pratinho, sem mistura, senta no chão e come. Sem mistura. Nossa! Você fala: 'Meu Deus, por que que eu fiz essa mesa?'. Ele dá para a gente perceber assim: 'Por que você não faz isso com todo mundo: arruma a mesa para os pobres aqui e chama?"”. (João)

Disposto ele mesmo ao sacrifício que colocasse em evidência os mais sofridos da sociedade, dormia nas ruas com sua "cama" de papelão, fazia jejuns pelos famintos, comia sentado no chão. Quando chegou e foi morar na favela, fazendo as missas num barraquinho, só podia ser um "padre doido". 
Sueli Damergian (2009) chama a atenção para a importância dos modelos saudáveis de identificação. Pessoas amorosas, cônscias de si mesmas, indulgentes, com o perdão sempre à frente da agressão, dispostas a desobedecer e lutar por causas que promovam os valores e as pessoas que amam, responsáveis pelo próximo. Essas pessoas, ao transmitirem aquilo que vivem, atraem os outros para a luminosidade de sua coerência, espalham tais valores e despertam os demais para construírem juntos um mundo melhor.

Madalena lembra as palavras de padre Alfredinho quando estava perto de morrer, palavras em comunhão com toda a sua vida. Temperadas com um bom humor que a fé lhe cultivou:

"E quando ele estava quase para morrer, ele disse assim: 'Ah, eu tenho um sonho... eu tive um sonho', 4 horas da manhã. Então, a gente dormia lá com ele, junto com ele e a Selma, se precisasse acordar à noite.

Então, na noite que eu estava lá ele acordou, de madrugada, e falou assim: 'Eu tive um sonho. Eu sonhei que tínhamos que alimentar muita gente, muita gente mesmo'. E ele sempre falava desse sonho de alimentar o povo, de ajudar.

Daí eu falei: 'Padre Alfredinho, o senhor está melhor hoje?'.

Ele falou: 'Estou. Só estou esperando Jesus dar uma piscadinha pra mim e falar que chegou minha hora'.

Assim, sabe, ele não perdia o entusiasmo. Ele sempre tinha uma palavra nova pra dizer para a gente, sempre. Muito bom...”. (Madalena)

E suas palavras transmitem não apenas a si mesmo como também seus sonhos. Ambas, ações e palavras, testemunham quem ele era. E cheias de experiência, ligam passado e futuro. Conectam as raízes de suas referências mais profundas com o futuro dos que virão e podem encontrar um campo mais fértil. Ele vai buscar no passado o testemunho de um Jesus que andava com o povo, e sonha um futuro de povo alimentado.

"Que moribundos dizem hoje palavras tão duráveis que possam ser transmitidas como um anel, de geração em geração?”, pergunta Walter Benjamin (1994, p. 114). Padre Alfredinho é lembrado, entre outras coisas, por isso: suas palavras são preciosamente duráveis, patrimônio humano, portadoras de valores que esperam o momento de prevalecer e de necessidades radicais que pressionam as circunstâncias para uma transformação totalizante.

As lembranças das pessoas - padre Mahon, Zé Bento, dona Margarida, pais e mães, padre Alfredinho e tantos outros - são histórias que merecem alcançar gerações vindouras. Irmanados com outras tantas pessoas que povoam de exemplos estas memórias, são indivíduos que, mesmo no seio de uma sociedade capitalista, antecipam características que 
poderão se tornar predominantes com a superação totalizante da sociedade do capital. Características do que desde já podemos visualizar como "indivíduos sociais ricos". E que talvez se generalizem no futuro da sociedade

[...] como sujeitos autônomos que podem obter sentido de (e, ao mesmo tempo, dar sentido a) sua própria vida como indivíduos sociais particulares, plenamente cientes de sua parte - e responsabilidade - em assegurar o desenvolvimento positivo historicamente sustentável de sua sociedade. (MÉSZÁROS, 2008, p. 103).

São pessoas portadoras de iniciativas conectadas a outros que, do passado, antecedemnas. Iniciativas ligadas a valores que, assim, ficam preservados no presente. Esperança para adiante. 


\subsection{Memória e solidariedade}

Fizeram uma festa na rua. Tem bebida, comida, dança. E as crianças de famílias pobres? Nem precisa se preocupar, tem kit com lanche para todas. E o dinheiro arrecadado? Era barato, mas sobrou. Então, um doente precisou de remédio, a tempestade destelhou a casa de uma família, caiu um barraco, faltou cesta básica... estão lá o remédio, as telhas, o material para construção, com o dinheiro da festa. E uma mão companheira para ajudar na lida.

Vai ter passeio da comunidade. E quem não pode pagar? Os que podem inteiram para os demais. É o dia todo? Como vão comer? Lanche comunitário, ué. De cada alimento levado, tudo é juntado e partilhado. E todos se alimentam.

O povo está comendo pouca fruta e legume? Opa, que tal organizar um sacolão e comprar direto dos produtores para ficar barato? E lá estava o sacolão toda semana.

A greve dos metalúrgicos está se alongando, começa a faltar comida em casa, mal dá para pegar ônibus. E agora? O jeito é colaborar com o Fundo de Greve. Vale até ir vender suco e comida para arrecadar dinheiro. Mas nem todas as famílias aqui são de metalúrgicos... Não tem problema. É pra ajudar? Então, mãos à obra.

Está uma seca terrível no Nordeste. Quem tem a ver com isso aqui em Santo André? Todos. É gente, são irmãos, somos nós.

E mais. Levantar barracos, encher laje, limpar a casa da vizinha adoentada, levar água para ocupantes de terrenos, participar de mutirões, ajudar desempregados, fazer sacolada de mantimentos, integrar atividades cooperativas de geração de renda, são algumas das muitas experiências compartilhadas pelos moradores da região. Nas evocações do passado não estão a anomia e o individualismo, mas sim o forte componente solidário.

E assim vão as comunidades da São Geraldo fazendo o termo "solidariedade" ser gesto concreto, visível, tão fácil de entender. “[...] Os sentidos e o espírito do outro homem se tornaram a minha própria apropriação.” (MARX, 2010, p. 109, grifo do autor). Se é assim, como Marx diz, então por que não ajudar o outro? Afinal, o outro é mais do que meu próximo, o outro me confirma assim como eu o confirmo.

Observa-se uma consciência de universalidade muito ligada à solidariedade: o outro sofre como eu, se alegra como eu, e mesmo que não estejamos passando pelas mesmas situações no momento imediato, podemos passar, pois o que você vive e sofre é fruto das possibilidades do gênero humano, dos sentidos humanizados. Se aquele com quem me solidarizo é meu vizinho de rua ou se mora na outra ponta do país, não é o que determina a disposição de ajudar. Todos são vistos como parte de um mesmo corpo sagrado. Não há uma 
barreira entre o bem do outro e meu próprio bem. Lavar a roupa da vizinha que está doente é um dever da própria condição de fragilidade que todos compartilhamos. Ajudar na ocupação de terrenos, assumir tarefas como cozinhar e levar água para os ocupantes, é sentir junto as dificuldades de moradia às quais todos os pobres estão sujeitos. Levar as crianças da rua para o cinema, para a natação, ensinar brincadeiras, é elevar as relações acima do núcleo familiar, ver as crianças como frutos da humanidade antes de serem desta ou daquela família, e perceber na comunidade humana uma possibilidade de integração muito mais ampliada. Ensinar a fazer e ajudar a vender panos de prato, coadores, pão para gerar renda às famílias desempregadas, é um desdobramento de si mesmo, vendo na caminhada do outro os obstáculos produzidos pela desigualdade que todos sentimos na pele.

Ao discutir a relação entre indivíduo e gênero humano, Mészáros traz oportunamente as reflexões do renascentista Paracelso (citado por MÉSZÁROS, 2006, p. 252, grifo do autor):

Não deveis julgar as pessoas pela sua estatura, mas honrá-las todas igualmente. $\mathrm{O}$ que existe em vós existe em todos. Cada um tem aquilo que também tendes dentro de vós; e o pobre cultiva as mesmas plantas em seu jardim que os ricos $[\ldots]$.

O reconhecimento da importância do outro começa, para estes cristãos engajados, como identificação de alguém muito amado, como visualização de uma testemunha referencial extremamente importante presente em cada pessoa: Jesus de Nazaré. Como dizem, esse "Deus no meio do povo" que é também Deus no povo. "Você muda todo aquele conceito de Igreja, de padre, de Deus. Até a maneira de se olhar Deus: você olhava Deus lá em cima. Nunca vê Ele. Ensina você a ver no outro, no irmão, na necessidade do outro". (Messias)

Rica em referências de solidariedade, as fontes bíblicas - e uma abordagem de leitura que valorize estes aspectos - constituem impulsos constantes aos participantes de CEBs e grupos afins. Considera-se o sagrado sempre presente no mundo e, especialmente, nas pessoas. E entre as pessoas, apontam decisivas indicações de que o sagrado seja buscado principalmente naqueles mais profanados pelas condições de opressão.

Exemplar a passagem em que o evangelista atribui à narrativa de Jesus a identificação do divino com os mais sofridos do povo: 
'Pois tive fome e me destes de comer. Tive sede e me destes de beber. Era forasteiro e me acolhestes. Estive nu e me vestistes, doente e me visitastes, preso e viestes ver-me'. Então os justos lhe responderão: 'Senhor, quando foi que te vimos com fome e te alimentamos, com sede e te demos de beber? Quando foi que te vimos forasteiro e te recolhemos ou nu e te vestimos? Quando foi que te vimos doente ou preso e fomos te ver?' Ao que lhes responderá o rei: 'Em verdade vos digo: cada vez que o fizestes a um desses meus irmãos mais pequeninos, a mim o fizestes'. (BÍBLIA..., Mt 25, 35-40)

Se não bastasse chamar os pequeninos de seus irmãos, este divino ainda deixa claro que habita neles e que a atitude em relação e esses pequeninos está perfeitamente refletida na atitude voltada para com a divindade. O próprio Deus se coloca numa atitude de solidariedade radical, e os sofrimentos e alegrias dos oprimidos se tornam sua própria apropriação de sofrimentos e alegrias. Isso vindo de uma testemunha referencial tão cara aos cristãos engajados - o Filho do Homem, como é denominado no Evangelho de Mateus - possui uma força muito intensa para a adesão a atitudes semelhantes.

No envio de recursos do povo da São Geraldo para os flagelados da seca, habita uma forte manifestação desta solidariedade. Delineia-se uma forma de abraçar a vida que é sempre, também, abraçar o outro. A vida individual e a universalidade se tocam, compondo as pontes entre indivíduo e gênero humano.

O jejum de vários dias, o envio de dinheiro para o Nordeste, as celebrações sintonizadas aos sofrimentos dos que viviam na seca, tudo isso já seria altamente admirável. Mas sabendo que o povo daqui também é pobre, e fizeram esforços significativos para ajudar os que estavam em situação pior, é realmente de uma radicalidade profundamente solidária.

"Então, teve pessoas que deixaram de fumar e davam o dinheiro para o padre Alfredinho. Parou de fumar, nunca mais fumou. Teve pessoas que deixavam de comprar alguma coisa durante aquele mês, pro dinheiro. As crianças participavam. E pessoas que deixaram de pagar o ônibus, iam a pé trabalhar pra poder passar o dinheiro". (Madalena)

Esses testemunhos, como os dos que iam trabalhar a pé para sobrar dinheiro e ajudar o povo do Nordeste, são tocantes. E marcaram fundo na memória de quem narra.

Quem lembra, não lembra desgarrado daquilo que viveu. Pelo contrário, se o que fica é o que significa (cf. BOSI, 1994, p. 66), as narrativas dão a entender que há um sentido em trazer à tona o passado, reconstruído pela evolução da pessoa até o presente. Muitas vezes, nestas narrativas, o sentido do lembrado é a proximidade da experiência vivida com o 
presente do narrador. Quase como se o presente fosse o ápice do desenvolvimento de alguns valores ao longo de uma trajetória. E o lembrar dá forma a esse sentido. Eis mais um motivo de esperança quando há tantas evocações de atitudes solidárias. Estes memorialistas, povoados de exemplos, são portadores de preciosíssimas práticas em relação aos outros. Práticas que eles mesmos apreciam ao contar cheios de sentido.

Vão da atenção de Margarida aos mais invisíveis - como o bêbado que ela levantou com limão no pulso ou a família de migrantes para quem Margarida conseguiu um pedacinho de chão - à memória-reflexão de João sobre a solidariedade aos mais pobres do bairro.

"Então, a gente vai aprendendo, nas Comunidades Eclesiais de Base, a não ser explorado, a viver uma vida digna, a viver não só para a gente, mas para o seu próximo, para a pessoa que está do lado. Mesmo eu tendo a água na minha torneira, eu tendo luz na minha casa, eu tendo asfalto na minha porta, eu tendo tudo organizadinho, mas tem aquele meu irmão que está lá na favela, que não tem esgoto - está correndo a céu aberto -, não tem um encanamento, não tem nada. E está tudo jogado lá, aquele meu irmão está necessitado. Então, eu tenho que estar do lado dele, reivindicando para ele". (João)

Trata-se de um amor de gratuidade, ligado àquele tipo de ganho que beneficie o outro sem necessariamente trazer qualquer benesse direta para quem o promoveu. Tal como Enrique Dussel (1986, p. 20) identifica o amor cristão: "amor ao outro enquanto sua própria realização, embora disso eu mesmo não consiga nada". Aquele amor que de tal modo busca promover a vida do outro (é oportuno lembrar que o termo "promover", tão utilizado no contexto do Cristianismo da Libertação, é exatamente "mover para adiante") que abre até mesmo a possibilidade de dar a vida pelo irmão. Dessa maneira,

O amor ao outro como outro é encanto, beleza, bondade, santidade, dom [...]: dom de si mesmo, entrega, opção sem retorno: 'Ninguém tem maior amor do que quem dá sua vida pelos amigos’ [Jo 15,13]. (DUSSEL, 1986, p. 20).

Aqui, é possível identificar várias fontes minando os valores de onde estes narradores e o povo que eles narram beberam e agora distribuem aos sedentos.

Desde os tempos de interior, em que os vizinhos partilhavam alimentos, faziam rodízio de ajuda uns nas roças dos outros, dividiam a mesma casa de farinha, comungavam juntos as festas religiosas, o aprendizado da solidariedade foi se emoldurando em suas vidas. Mas o 
acolhimento que receberam, as ajudas das quais foram objetos também parecem contribuir na formação deles.

Depois de uma viagem fatigante e o choque da migração, a primeira manhã de Madalena em Santo André foi suavizada pela vizinha. A conversa inicial trouxe a sensação de familiaridade a Madalena. A solicitude da vizinha ao dar sabão para lavar a roupa ligou Madalena a suas referências mais aconchegantes: a referência de casa, a forma de convivência na qual tinha sido criada no Paraná. E Madalena chegou à conclusão de que aqui os vizinhos também são bons. Depois, o prato de comida que a vizinha preparou foi como um pouquinho de água no novo solo. As raízes de Madalena, quem sabe, poderiam buscar sua sustentação e substância na nova cidade. Como um lampejo, Madalena pôde vislumbrar um novo enraizamento nesse primeiro contato acolhedor e marcado pela solidariedade da vizinha.

E Messias, que também era nova no bairro. Talvez acuada pela precariedade, pelas inseguranças de ser uma jovem mãe tentando cuidar dos filhos numa vizinhança agressiva. $\mathrm{E}$ toda a necessidade de ser aceita, ser respeitada, ser amada. Pois a vizinha, como uma mãe, tratou de acolher Messias e seus filhos. Preparou o caminho para a jovem mãe se inserir no bairro e, depois, transformar tantas relações. Josefa, a vizinha, fez o bem que não se paga. Foi solidária. Ensinou com a vida. Messias até hoje saboreia essa gratidão.

Daí pra frente, engajadas nas CEBs, Madalena e Messias retribuem os gestos que receberam devolvendo outros muitos pela vida afora. Num processo em que não se pode esquecer das formas de solidariedade caipira como origem, as narrativas indicam o movimento em direção a uma consciência explícita da solidariedade que praticam, cultivada nos grupos de CEBs, JOC, ISSO, entre outros. Dão exemplo daquilo que poderá ser a maneira predominante de ser no mundo: o indivíduo social.

Ao sistematizar a noção de Marx sobre a concepção de indivíduos sociais, contrastando-a tanto em relação ao isolamento capitalista quanto à fusão de indivíduo e sociedade num estado burocrático, Mészáros (2006, p. 246, grifo do autor) nos ajuda a visualizar esse modo de ser:

Ele (Marx) conclui que a alienação só é transcendida se os 'indivíduos se reproduzirem a si mesmos, porém como indivíduos sociais'. Assim, na visão de Marx, o indivíduo numa sociedade socialista não dissolve sua individualidade nas determinações sociais gerais. Ao contrário, tem de encontrar um escoadouro para a realização plena de sua própria personalidade (Gesamtpersönlichkeit). Numa sociedade capitalista, os 
indivíduos só se podem reproduzir como indivíduos isolados. Numa sociedade burocraticamente coletivizada, por outro lado, eles não se podem reproduzir como indivíduos, e muito menos como indivíduos sociais. Em ambas, a esfera pública está divorciada da esfera privada e opõe-se a ela, por mais diferentes que possam ser as formas dessa oposição. Segundo Marx, em contraste, a realização da Gesamtpersönlichkeit implica necessariamente a reintegração de individualidade e socialidade na realidade humana concreta do indivíduo social.

Conectados à humanidade, cada participante de CEBs vai desenvolvendo a noção de sua vinculação. O bem é expandido para além das satisfações individuais. Os grupos que atuavam - ou ainda atuam - na região da São Geraldo, como as CEBs e outros, tinham essa característica solidária. Como nas greves: nem todos trabalhavam diretamente nas fábricas, mas a luta era reconhecida como parte de um mesmo processo de libertação, de construção de um caminho para a humanidade, do qual suas lutas eram uma parte. E, assim, donas de casa se unem aos operários, padres vão para as portas das fábricas, o bairro se liga ao mundo, o indivíduo à humanidade. 


\subsection{Pessoas, espaços, pessoas... (lugar das gentes)}

Um lugar não é feito apenas de suas casas, ruas, matas, edifícios públicos, jardins. É feito pelas pessoas que humanizam o lugar e se organizam nele. A disposição de casas, o espaço entre elas. A matéria das ruas, a largura delas. Se há mais pássaros acordando a manhã ou caminhões rasgando o dia. Quais os cheiros presentes, quais as cores presentes. Tudo denota uma relação humana com o lugar. E denota também como se dão as relações entre humanos. Às vezes, humanos que relegam outros a condições precárias e que tiram dessa precariedade o sustento de sua abastança.

Lembro bem de uma das antigas moradoras do bairro contando com lamento sobre sua situação quando veio para Santo André, em 1959. Nascida e criada no campo nordestino, seu sentimento era de que saiu da roça para vir a um lugar que não era nem sítio nem cidade.

As casas dispersas, água cavada em poço, frio e barro. Barro que grudava nos sapatos e nas memórias. Fazia-se necessário sempre levar uma faquinha na bolsa para limpar os calçados quando chegasse no Centro.

Também antiga moradora da região, Margarida lembra da época de sua chegada, no início dos anos 70.

“Aqui não tinha luz e nem asfalto. A região aqui era mais taboa. Conhece taboa? A taboa é assim: ela cresce e depois ela solta uns pendões. Tinha até gente que pegava os pendões e mandava pintar para colocar em vaso dentro de casa. Então, isso aqui era taboa e capim. E também tinha grotinhas, era tudo assim, sabe, minando água. Em todo lugar que você punha terreno, minava água. Não tinha casa nenhuma por aqui. Lá na Valentim Magalhães, que foi onde eu fiquei também, não tinha. Tinha um tancão lá pra cima que só morria gente todos os dias". (Margarida)

A intersecção entre campo e cidade, atividades agropastoris e industriais, mata fechada e urbanização, permanece em alguma medida até hoje. Passando cedinho da manhã no final da Avenida Valentim Magalhães é possível avistar uma senhora levando cabras e cabritos para pastar na beira da mata. Também tem quintal com criação de galinhas para vender. É possível olhar para um lado e ver obras de loteamento e de construção de vias e, ao mesmo tempo, olhar para o outro lado da estrada e avistar plantações de frutas perto da mata. Cavalo e automóvel tão perto. Minas d'água e dutos da Petrobras vizinhos. Na periferia, mundos se encontram com uma vivacidade estonteante. A carência material e a desigualdade são partes desta conformação. Os valores humanos trazidos como bens imprescindíveis também. Tudo faz parte do que se tornou e continua se tornando esta região. 
Hoje, o espaço é densamente povoado. Mas, nas memórias, há um trajeto que mostra o desenvolvimento das várias faces do lugar. Um certo isolamento das casas transparece nas lembranças dos primeiros tempos, na chegança dos habitantes que ainda podem nos contar como era. Percebe-se um sentimento de anomia relacionado às lembranças do estágio menos populoso da região. Anomia que vai sendo transfigurada pelas iniciativas conscientes das pessoas.

"Porque esses vizinhos, era um vizinho aqui, o outro ali, muito terreno vazio. Mas eles brigavam feio lá. Depois a gente ficou tudo amigo, tudo assim”. (Messias)

"Na época de 69, aqui em cima era muito morto. Não tinha luz na rua. Tinha poucas casas. Aqui tinha uma casa, aí tinha essa do lado, tinha outra. Aqui não tinha, aqui também não tinha, do outro lado não tinha. Onde nós moramos, aí no salão, eram uns eucaliptos. Aí era aquela rua. Aí eram uns barrancões, bastante terra. E eram uns eucaliptos, era uma estradinha. E até na São Geraldo ainda tinha asfalto. Mas tinha pouca casa também. Não tinha muita casa, não". (João)

A amizade que se desenvolve liga as pessoas e ressignifica o espaço. Aos poucos, as festas, as reivindicações organizadas, as reuniões de grupos, passam a preencher o espaço físico e emocional entre as casas. Nas memórias, a região vai ganhando os contornos de comunidade.

Ao falar em comunidade, alude-se aos agrupamentos em que vigem as relações primárias, com forte componente afetivo, relação nominal e interpessoalidade (cf. BOFF, 1978, p. 51). Também é possível acrescentar a estes elementos as formas de relacionamento com gradações marcantes de intimidade pessoal, profundeza emocional, engajamento moral, coerção social e continuidade no tempo (NISBET, 1977).

Em termos de referências cristãs - que, sem dúvida, são fontes de formação fundamentais para as pessoas aqui consideradas -, o amor entre as pessoas na relação face a face é apreendido como valor imprescindível para a alusão à comunidade. E este amor não se separa nem da justiça e nem da partilha totalizante, em que tudo é colocado em comum (DUSSEL, 1986).

Por parte dos diversos participantes do universo de CEBs - desde o povo que integra os Grupos de Rua até os teólogos ligados à vertente da libertação - é comum que sejam citadas as primeiras comunidade cristãs como exemplo de relação comunitária.

Eles mostravam-se assíduos ao ensinamento dos apóstolos, à comunhão fraterna, à fração do pão e às orações. Apossava-se de todos o temor, pois 
numerosos eram os prodígios e sinais que se realizavam por meio dos apóstolos.

Todos os que tinham abraçado a fé reuniam-se e punham tudo em comum: vendiam suas propriedades e bens, e dividiam-nos entre todos, segundo as necessidades de cada um. Dia após dia, unânimes, mostravam-se assíduos no Templo e partiam o pão pelas casas, tomando o alimento com alegria e simplicidade de coração. (BÍBLIA..., At 2, 42-46, grifo nosso).

Tal exemplo é vivido nas visitas que as pessoas fazem umas nas casas das outras. E na unidade desenvolvida para abraçar as causas uns dos outros. O espaço vai se povoando não só de casas, de comércios, de asfalto, de creches, de escolas. Vai se povoando de experiências compartilhadas. Vai formando o que hoje nos é presenteado como memória.

“O pessoal se organizava, se inscrevia, fazia filas, e o mutirão era assim ó: eles davam o material, e cada um ia construir a casa do outro, o outro ia construir a casa do outro, e um ajudando o outro. É o sistema do mutirão. Aí, se queria fazer uma praça, a prefeitura vinha com o material e os moradores construíam a sua praça. E a gente trabalhou muito em cima disso, da questão de os próprios moradores ganharem o material e eles fazerem. 'Quero uma praça aqui', e fazer uma praça aqui”. (Messias)

Como reflete Ecléa Bosi (1994), os espaços também são arrimos onde se apóiam nossas memórias, inseparáveis dos eventos neles ocorridos. São verdadeiros mapas afetivos da cidade.

Ecléa também chama a atenção para o fato de que certa disposição espacial é fruto de grupos humanos e que, portanto, são imagem deste grupo. "Podem arrasar as casas, mudar o curso das ruas; as pedras mudam de lugar, mas como destruir os vínculos com que os homens se ligavam a elas?” (BOSI, 1994, p. 452).

Relações de vizinhança, solidariedade, reciprocidade. A pobreza é colocada frente a frente com a força do vínculo. Os mutirões, o socorro prestado nos apuros, os laços duradouros de amizade, a participação nos mesmos problemas e nas mesmas conquistas, a celebração religiosa diretamente ligada na vida das comunidades, são todas expressões da feição que os moradores dão à região abrangida pela pesquisa.

Lembra os bairros rurais estudados por Antonio Candido (2001). Em sua pesquisa sobre os caipiras paulistas, ele verifica que os bairros possuem como características: reunir famílias agrupadas e vinculadas pelo sentimento de localidade, pela convivência, pelas 
práticas de auxílio mútuo e pelas atividades lúdico-religiosas. Ainda que não seja possível afirmar a coincidência direta e total de características entre a região da Paróquia São Geraldo e os bairros rurais aos quais se refere Candido, não deixa de ser oportuno perceber proximidades.

Aqui, um momento de ruptura. É preciso partilhar o testemunho de uma violência a esse laço comunitário. Em 2011, aconteceram diversos despejos em Santo André. A imagem era desoladora. Mas antes, algumas das miudezas cheias de significação humana.

Numa das ruas em que houve despejo, numa favela, logo cedo alguns moradores estavam reunidos em torno de uma fogueira. Em sentinela, esperavam. Era uma resistência fatigada pela dureza da situação e pela noite sem sonhos. Subi numa das casas para usar o banheiro. Num dos cômodos, um rapaz acordando. Quieto, sentado na cama, era sua despedida do quarto que o abrigou todos esses anos.

Depois, o policiamento. Um exército de carros, cavalos, ônibus, armas. E os moradores se dando conta do avassalamento. Revolta, tristeza, perplexidade, quantos rostos!

Quando o oficial de justiça começou a passar nas casas, escoltado, a resignação, o choro, a tentativa de resistência e o olhar perdido compunham as cores da reação. Ou a falta dela. Ou a impossibilidade de reação. A possibilidade como momento futuro?

E o dia seguiu assim, com os caminhões de mudança enviados pelo Município indo e voltando, alguns moradores tentando aproveitar até mesmo as telhas das suas casas para a insegurança do porvir. Sem que a prefeitura oferecesse alternativa de moradia aos despejados, a fumaça dos caminhões não era incenso aos Céus por um futuro esperançoso, mas sinal de um incêndio tão antigo quanto a existência de sociedades divididas em classes. Era fumaça de violência que os escapamentos lançavam no pulmão da cidade.

Enquanto um dos caminhões de carreto saía da favela com mais um carregamento do despejo, uma menininha de uns 3 anos dava tchau para ele com sua mãozinha erguida. E quem sabe o que se passava no coração de cada um... Um homem nos permitiu saber: dizia que triste não era somente deixar a casa em que mora há 20, 30 anos, mas também deixar os vizinhos com quem se acostumou a conviver.

Aqui é possível retornar desse momento de ruptura com, talvez, uma certeza a respeito de como espaço e pessoas se relacionam. Vizinhos são, de certa forma, o lugar.

Nas memórias, a base comunitária assenta o bairro no coração dos narradores. Messias detalha com gosto a organização das festas. Tinha desde as brincadeiras para as crianças até o forrozão da noite, com violeiro e tudo. Todos ajudavam e todos usufruíam. Ela lembra como a associação entre as pessoas perpassava vários espaços do bairro: a escola, a rua, a igreja. 
Todos os narradores se lembram de como as carências do bairro foram enfrentadas coletivamente. A situação de anomia e dispersão é superada pelas necessidades que são desafiadas pela força da união entre vizinhos. A comunidade se forma, ou seja, formam-se os laços pessoais, face a face. Todos passam a ter um nome.

Aliás, essa é outra marca importante que permanece. Algo possível de se presenciar quando se vai a uma reunião de CEBs nas casas é a grande preocupação demonstrada para com os vizinhos que não podem se juntar aos demais no encontro. Ninguém cai em dificuldades sem que a comunidade saiba. Todos se conhecem pelo nome. Ou, se há dificuldade em saber o nome de um rapaz mais jovem ou um vizinho de ruas mais distantes, há grande possibilidade de saber o nome dos pais ou identificá-lo por qualquer característica já bem observada pelos demais. Aquele de quem não se lembra o nome é filho de fulano, ou é aquele senhor, marido de fulana. Muitas vezes, o máximo de "impessoalidade" é não saber o nome. Mas daí não passa. Sempre pode haver outra referência que traz a pessoa para dentro do círculo de conhecidos da comunidade.

É possível que nos encontros, durante as orações, quase todos os pedidos sejam feitos para os vizinhos. Doenças, problemas com filhos caídos em dependências, violência, cirurgia marcada. As pessoas indicam grande conhecimento das histórias de vida uns dos outros. Nada passa despercebido.

Quem passar no comecinho da noite numa das ruas da região, certamente verá crianças brincando de esconde-esconde, de bola, verá homens conversando em bares, garagens abertas com pessoas em cadeiras, batendo papo. Não será só isso nem só o agradável. Mas esses aspectos de uma socialidade muito vívida poderão ser sentidos numa forte lufada de esperança sobre a corrosão das grandes cidades.

Entre as muitas memórias que ligam espaços e pessoas, as lutas parecem desempenhar forte função de coesão.

"Não tinha nada. Tinha água na torneira, mas era muito pouco. Ninguém tinha caixa d'água. Também, a água quase não vinha. Não tinha ônibus, o ônibus vinha só até ali embaixo. Não tinha asfalto. Não tinha nada. Mas logo foi se construindo tudo. Logo que a gente chegou. Tinha um povo muito batalhador, né, assim, que fazia muita passeata, muito abaixo-assinado, faziam muitos mutirões. E daí foi indo. Foi uma época que, assim, acho que todo mundo resolveu vir pra São Paulo e ficar ali, assim, um povo que queria realmente lutar mesmo". (Madalena)

No meio da organização para lidar com as necessidades, a amizade brotou. A solidariedade cresceu. Quantos foram os frutos que até hoje são visíveis em cada equipamento 
social, em cada vida fortificada pela caridade autêntica de vizinhos abnegados - e alguns, até hoje, chegam a se dedicar regularmente a doentes da vizinhança.

"E a nossa amizade era tão boa que, por exemplo, se alguém estava doente a gente ia ajudar a pessoa, limpar uma casa para ela. Se outro estava com problema, a gente se reunia e ia lá ajudar. Se estava desempregado, a gente ia ver a necessidade dele, o que ele estava necessitando naquela casa. Se outro ia procurar serviço, às vezes não tinha dinheiro para o transporte, e a gente dava dinheiro para o vale-transporte". (Messias)

Aquilo que surgiu motivado, em grande parte, por necessidades, tornou-se laço. E os laços humanos passaram a ser centro das vidas das pessoas.

Marx se impressionava ao ver como era possível visualizar os homens e a sociedade como fins e não como meios de qualquer outra coisa, mesmo com tantas pressões contrárias na sociedade do capital. Ele percebia que as relações entre os socialistas franceses, ainda que começassem como meios, enriquecia-se num convívio que, entre eles, gerava a finalidade humanística do encontro. Marx (2010) mesmo nos conta:

Quando os artesãos comunistas se unem, vale para eles, antes de mais nada, como finalidade a doutrina, propaganda etc. Mas ao mesmo tempo eles se apropriam, dessa maneira, de uma nova carência, a carência de sociedade, e o que aparece como meio, tornou-se fim. Este movimento prático pode-se intuir nos seus mais brilhantes resultados quando se vê operários (ouvriers) socialistas franceses reunidos. Nessas circunstâncias, fumar, beber, comer etc., não existem mais como meios de união ou como meios que unem. A sociedade, a associação, o entretenimento, que novamente têm a sociedade como fim, basta a eles; a fraternidade dos homens não é nenhuma frase, mas sim verdade para eles, e a nobreza da humanidade nos ilumina a partir d[ess]as figuras endurecidas pelo trabalho. (p. 145, grifo nosso).

A partir deste belíssimo texto de Marx, é possível imaginar como estes socialistas franceses se lembrariam dos espaços onde se reuniam. Quanta concretude poderia pontilhar suas lembranças. Palavras como amizade poderiam ser compreendidas na concretude dos amigos. Fraternidade ser vivida na concretude de gestos entre os companheiros. Ali, provavelmente, não seria apenas um lugar, mas vida vivida em tempo e espaço qualificados pela experiência. 
Espaço, amor, amizade e lutas se interligam. Compõem a comunidade. Comunidade no espaço. Espaço da comunidade. 


\subsection{Memória em três tempos}

"Tem horas antigas que ficaram muito mais perto da gente do que outras, de recente data. O senhor mesmo sabe." (ROSA, 2001, p. 115).

Fazendo essa reflexão, Riobaldo se dá conta das muitas maneiras de se vivenciar o tempo. O tempo do relógio sendo tão diverso do tempo da espera por uma visita, a passagem dos anos contada pelo calendário sendo tão estranha à proximidade do passado no presente, pulando todos os anos que a folhinha indica sem saber que a vida vivida perpassa todos os tempos que seguem após. Como diria nosso amigo dos Grandes Sertões, há momentos que se percebe para sempre.

Não é de se estranhar a riqueza de detalhes presentes mesmo em algumas das memórias mais antigas na biografia de alguém. O próprio Riobaldo continua partilhando mais um pouco de suas noções sobre o tempo narrado:

A lembrança da vida da gente se guarda em trechos diversos, cada um com seu signo e sentimento, uns com os outros acho que nem não misturam. Contar seguido, alinhavado, só mesmo sendo as coisas de rasa importância. (ROSA, 2001, p. 114).

Assim, agrupando as lembranças em trechos, com sentimentos diversos, nossos narradores formam suas memórias. Em linhas gerais, é possível notar três divisões fortes comuns aos quatro narradores. Tratam-se de: 1- memórias de infância e juventude; 2memórias do tempo em que as CEBs e outros grupos afins são lembrados como muito ativos; 3- memórias ressequidas por certo tom de lamento acerca dos tempos atuais em que a participação é sentida como esvaziada. Esses três momentos fortes não resumem as marcas temporais das memórias. Há gradações, pontos de inflexão, períodos de transição entre momentos, e todos esses trechos compõem uma noção tendente à totalização da vida, entendida também por suas gradações temporais em inter-relação.

É impressionante como em alguns a infância é vívida. Detalhadas, umedecidas com sentimentos facilmente acessados no presente, estas lembranças despontam caminhos trilháveis ainda hoje. João e Margarida guardam a felicidade dos primeiros anos de vida. Roças bonitas das quais se orgulham abrem-se à vista. É café, amendoim, arroz, mandioca, algodão. A distância entre a produção e o desfrute dos alimentos era quase o tempo de levar o 
sabor à boca. Às vezes, bastava apenas uma pisada na melancia e pronto, lá se dava a frutona toda suculenta para o deleite da meninada.

Ao conversar não apenas com os narradores destas memórias mas também com outras pessoas vindas de origem rural, percebo como os sabores dos alimentos da infância são uma das forças mais nostálgicas que latejam nas lembranças. A carne conservada na banha, o pão feito em casa, o tempero que a fumaça da lenha emprestava à refeição, as frutas colhidas no pé, a farinha, o torresmo, os doces que tinham a duração da semana e da sazonalidade das frutas, a água de bica. Mesmo os alimentos que não eram apreciados na época hoje são evocados com carinho. Tal qual a polenta que a mãe de João fazia.

Como o relato do passado carrega significações emprestadas por experiências posteriores ao fato vivido à época, os narradores ponderam sobre as durezas da vida juvenil levando em consideração que não as sentiam tão duras quando viviam em tais condições.

"Não tinha sofá a sala. Eram aquelas mesonas brutas, aquelas cadeiras de madeira, aquele fogão de lenha, que enchia de fumaça. Quando a lenha estava meio molhada, não pegava fogo e enchia de fumaça a casa, ficava tudo preto. Olha, aquilo é vida hein, meu. Para o cara aguentar não é fácil, não. Hoje eu não aguentaria. Mas na época, você está criado aí... E era uma vida saudável”. (João)

Já para Messias e Madalena, as nuances da infância aparecem em meios-tons. Muitas dificuldades fazem doer o esforço de lembrar. E juntinho ali da dor, a alegria. Tudo misturado, tudo se coalhando e se derretendo, dores e alegrias, umas agindo nas outras. Messias passava pela falta de recursos armando estratégias sapecas para comer os cafés da manhã maravilhosos do padre.

"Eu participava na Igreja. Eu batia o sino da igreja. Era tão legal, Gustavo. Nós éramos bem pobres mesmo. E o padre, ele, nossa!, tinha uma mesa farta de comida, sabe. O café da manhã do padre era uma coisa do outro mundo para a gente que não tinha nada. Aí, a gente combinava, eu e o meu irmão: 'Vamos lá bater o sino pro padre?'. (risos) Ele disse assim: 'Vamos'. Aí, o meu irmão se pendurava no sino que era menorzinho, que ele era bem magrinho e mais novinho, e eu me pendurava no grandão. E a gente ficava batendo o sino para ele. Depois, ele chamava a gente para tomar café, que era o que a gente queria. (risos)

Ah, mas era MUITO GOSTOSO! A gente comia aqueles bolos, assim. Nossa! Era muito gostoso". (Messias)

Apesar da pobreza de todos eles, com trabalhos duros, vida rústica e longas caminhadas de um lugar para outro, a vida tinha inteireza, as pessoas eram amplas em habilidades. As crianças faziam seus próprios brinquedos, iam participando do metabolismo 
da terra ao longo das estações, enfrentavam as situações com seus estratagemas divertidos. A vida era menos fragmentada, as pessoas também. $\mathrm{O}$ mundo da mercadoria era menos evidente: as pessoas se relacionavam com pessoas.

Não se deve cultivar ilusões sobre muitas das relações narradas na infância. Aqui também está presente a lembrança da parte produzida que o pai tinha que dar ao proprietário da terra, está presente a figura dos coronéis e baronesas que tinham lugar cativo nos bancos da igreja, a recordação da percepção de que os melhores empregos estavam reservados aos filhos dos fazendeiros, banqueiros e tenentes.

Mas chama a atenção o frescor dos fatos, da atmosfera, dos sentimentos evocados da infância. As humilhações, os sabores, a socialidade, as dificuldades, as cores, tudo vem intenso quando relacionado à infância. Pode acontecer de uma senhora, com seus mais de oitenta anos, abraçar a riqueza de seu passado com tanto carinho que não se contém:

"Aqui eu também trabalhei na roça. Minha vida foi trabalhar na roça, enxada, tudo. Eu peguei tudo, eu sou da roça mesmo. Eu choro de saudade porque não tem como...”. (Margarida)

Convido os leitores a retornarem às narrativas e verificar os relatos de infância. Não caberia relembrar tudo nesse momento. Mas vale a pena mergulhar nestas lembranças pujantes. Sigamos adiante. Um novo período forte das memórias vem chegando. Trata-se da época efervescente das CEBs, da JOC, da ADC, da ACO, dos partidos, da mobilização nos bairros, das greves... é o momento que nossos memorialistas narram como aquele que revela, para eles, o núcleo mais autêntico da atuação popular da Igreja.

Lembranças marcadas pelo entusiasmo, pela atmosfera memorial de apropriação da história nas mãos. Com tantas resistências presentes na conjuntura, mesmo assim a sensação de poder intervir na realidade é pronunciada. Quando parecia que os narradores sairiam de suas terras e deixariam o vigor das lembranças da infância, eis que narram esse novo momento com minúcia e força. A dúvida sobre o que encontrariam ao sair de seus lugares de origem aparece nas narrativas. É João que achava que não teria mais oportunidade de realizar o sonho de atuar organicamente nas atividades da igreja, é Madalena que por um momento achou que a vida iria se repetir nos empregos como doméstica, é Messias que chega a desistir de ficar em Santo André pela dureza de dormir em casa de patrão, é Margarida que desfiava a vida sem ter com quem palestrar. Em todos eles, um pisar em falso inicial, a desesperança, a dúvida sobre as vantagens de morar em Santo André. E em todos eles, o ponto de inflexão, o salto de qualidade, o ingresso na participação da igreja. Ou, como diria Margarida, "a luz do Divino Espírito Santo". E a vida se encheu de sentido. Daí pra frente, lutas, reuniões nas 
casas, mobilizações solidárias, formação de comunidade, enfrentamento das desigualdades, protestos, celebrações alicerçadas na vida do povo, amizades. Em todos eles, a constante saudade dessa época, de como as pessoas se organizavam, de como viviam em coerência radical com as convicções que compartilhavam, desde os mínimos gestos.

E, em contraste com o período entusiasmado das CEBs e da igreja, o terceiro grande momento das memórias: o refluxo atual. Necessariamente, este último período se remete ao período anterior. Aqui, a comparação faz constantemente a avaliação e o julgamento das experiências umas em relação às outras.

“Olha, vou falar a verdade para você: eu aprendi muito, aprendi muito, aprendi muito. Hoje, eu tenho a minha participação na Igreja, mas sinto muita falta dessa luta. Sinto muita falta, muita falta mesmo. Porque hoje não é nem sombra do que foi no passado. Hoje, a gente não vive nem sombra. Hoje, a gente está num país do primeiro mundo. As igrejas lá vivem de braços cruzados. E aqui, a gente, aos poucos, está cruzando os braços. Infelizmente. Está cruzando os braços aos poucos. Muitas vezes eu vejo que a Igreja precisava arregaçar as mangas, fazer algo. E muitas vezes a gente tampa, faz de conta que não enxerga. Por isso, às vezes tem momentos que dá tristeza. O que a gente viveu, dá saudade”. (João)

Uma das marcas que os narradores associam ao momento atual, para demarcar o contraste com os bons tempos da participação, é a mudança de nome. Chamar-se "Grupo de Rua" ao invés de "CEBs" parece fazer parte do pacote de recuos que diferencia o período ativo do período de "braços cruzados". O sentido da vida, tão ligado à participação, também sofre abalos. O lembrar vai ficando dolorido. Dor que cutuca mais porque a recordação da delícia veio logo antes. Madalena lembra da primeira missa no Vista Alegre, depois da ocupação. Anima-se, compara com hoje, reflete sobre a conjuntura para visualizar caminhos de atuação no presente:

"E daí, foi a primeira missa. Então, a gente, nossa!, eu lembro de todo mundo chacoalhando a mão. E foi uma SATISFAÇÃO que dava na gente isso, UMA ALEGRIA, eu não sei explicar o que a gente sentia. Parece que não é mais o mesmo entusiasmo igual a gente fazia naquela época. Era muito bom mesmo. E eu tenho bastante saudade. Tudo bem que a luta hoje é outra, né. Hoje nós temos que lutar contra as drogas, contra a violência, contra outros tipos de violência, outros tipos de escravidão. Mas parece que a luta perdeu o sentido. Perdeu o sentido...

E a gente conquistou tanta coisa, tantos direitos. Tantas coisas que a gente conquistou. Deveria ter o mesmo entusiasmo, mas não tem. Talvez outros valores, outros meios de vida pra se viver, né”. (Madalena) 
Se os narradores comparam os tempos de participação com certo lamento, suas próprias reflexões apontam caminhos para o adiante. Aparecem as ponderações sobre as condições de antes e as condições de agora. A própria efetividade das lutas passadas, de alguma forma, conecta-se ao refluxo da atualidade. Num momento em que a precariedade das condições de vida e a ascendência dos movimentos populares se relacionam dialeticamente, tanto mais as pessoas se organizam quanto mais evidentes são as dificuldades a serem enfrentadas. Falta tudo e sobra organização. Na medida em que as lutas geram conquistas, a organicidade das redes de atuação política vai se esgarçando. De alguma maneira, a organização das pessoas se apoiava no enfrentamento de problemas explícitos. Esse era um momento da organização e da consciência do povo. Mas o movimento não se esgotou. No novo momento, com desafios novos, com a opacidade da realidade em transição e, afinal, com parte dos objetivos do momento anterior realizados, não é fácil encontrar motivos profundos para se organizar. Quais são as questões? Quais são as necessidades? Quais são as lutas? Quais são os horizontes?

Mas nesse processo contínuo de consciência e de movimento da realidade, os memorialistas lançam pontos de luzes para entendermos nosso novo momento e suas contradições, possibilitando enxergar, no meio dos lamentos, as brechas do porvir.

"Mas, também, era uma época assim: o bairro não tinha nada, não tinha água, não tinha creche, não tinha organização, não tinha nada. Então, havia uma necessidade, entendeu. Eu acho que hoje as necessidades existem, mas são diferentes de quando eu vim para cá. As necessidades são outras. Precisa melhorar a escola pública? Precisa. Precisa melhorar a saúde? Precisa. O que precisa? A sociedade precisa de muitas coisas. Acesso a muitas coisas. Mas, hoje, os nossos jovens, até os mais pobres têm acesso. Eles podem ir ao cinema, eles podem ir ao teatro. Se ele quiser, ele tem lazer, tem tudo para ele”. (Messias)

Como disse Madalena sobre a importância de se descobrir os outros tipos de violência e de escravidão de hoje; como disse Messias acerca de efetivar as melhorias sobre bens públicos já conquistados como a escola, os serviços de saúde e outros. Afinal, hoje ônibus sobe até o bairro, mas a passagem é paga e cara. Como fica a situação do trabalhador que precisa pegar quatro, cinco, seis conduções por dia? Hoje há escolas públicas espalhadas por toda a cidade. Mas qual é a qualidade real das condições escolares? Hoje foram instalados postos de saúde que abrangem regiões. Mas o pobre doente continua morrendo aos montes por falta de condições satisfatórias para seu atendimento. Isso só para falar de momentos ainda reivindicatórios de direitos básicos. Podemos ir em frente e aludir à necessidade de sentido de vida, de perspectiva, de enriquecimento humano, de emancipação totalizante da 
humanidade. São desafios para momentos vindouros. Os desafios, pelo jeito, continuam. E como os companheiros e companheiras de CEBs e de tantos outros grupos populares, dentro e fora da Igreja, vêm contribuindo para o avanço da vida! Por tudo o que já fizeram e têm feito, há grande esperança de que a ética libertadora que carregam atine logo para a visualização dos novos desafios.

Diante das ponderações de Messias, por exemplo, já podemos dar passos adiante. As contradições entre o desfrute das conquistas e as dificuldades de seguir empurrando a sociedade para a frente, já nos coloca em reflexões mais frutíferas, porque cultivadas na lucidez de quem parou para refletir mas não parou de ansiar. Seus horizontes continuam largos como antes. Os valores superiores aos quais aderiram durante a vida seguem convocando à realidade. Talvez por isso mesmo à impaciência também. Nossos narradores sentem o fogo quentíssimo da esperança.

Se a crítica vem dura sobre o momento atual, é preciso entender que para quem já fez a cidade se revirar para abrir espaço às famílias das periferias, não é fácil conviver com a sensação de marasmo. Para quem mergulhou na experiência de uma espiritualidade vivida radicalmente no cuidado do próximo, é dura a sensação de que hoje o pessoal só reza e não vai ajudar a vizinha doente como antes. Mas a crítica é fermento. Necessária para fazer crescer o novo momento da consciência, quem sabe. Quem mergulhar as mãos no fundo das críticas vai retornar com preciosas pedras lapidadas para o futuro.

"E daí, eu acho que eles deveriam... não sei, é o meu pensamento... que deveriam começar a rezar a vida do povo, rezar a vida da nossa comunidade, a nossa vida, celebrar a nossa história, os acontecimentos de hoje". (Madalena)

A crítica está cheia de dicas. E cheia de indagações implícitas. Afinal, o que é o nosso "hoje"? Quais são os nossos acontecimentos? Como se insere nosso hoje na história? E para onde podemos apontar a partir daqui?

As CEBs, como qualquer outra criação humana, não é um fato acabado. Está em movimento. Às vezes tão invisível que nos dá comichão, desânimo, impaciência. Podemos comparar com um instrumento tão presente nas missas da periferia: a sanfona. Por serem bem-sucedidas nas conquistas das muitas metas às quais se dirigiram e lutaram, as CEBs se acalmaram, esvaziadas de lutas já travadas. Mas, talvez, esse momento de esvaziamento esteja já no fim, prestes ao novo ver-julgar, preparando, assim, um novo momento de lutas. Como a sanfona. Ela se esvazia à medida que vai conquistando as notas e sons daquele trecho da música. E se enche assim que acabam aquelas notas, buscando novo fôlego para as notas que precisam se seguir. Se enche e se esvazia num contínuo conquistar-conquistado, pausa, 
tomada de fôlego, encher, esvaziar, conquistar, conquistado, sons para fora, sons para dentro. Isso tudo no conjunto da música que, no final das contas, não se resume nem ao trecho se esvaziando nem ao trecho se enchendo, mas se faz no todo musical.

Precisamos da referência do que já foi para avaliarmos a realidade presente. Precisamos da referência utópica do que poderá ser, ou do que deve-ser, para intervirmos no presente. Ou seja, o presente, sem o vínculo com o passado e com os possíveis e desejáveis futuros, fica inerte, acomodado à situação que se apresenta como natural e imutável. Sem a noção do movimento, do devir, o presente fica muito empobrecido. Por isso, tanto o passado como o futuro são indicadores de movimento e de confiança na intervenção humana sobre as circunstâncias.

A comparação entre tempos é também um desafio para a consciência. Temos que nos movimentar, mas como é difícil passar pelas transições da realidade! É duro ver o entusiasmo da situação de ascenso ficar pra trás. Mas será que ficou mesmo? Quem sabe dos brotos que hoje estão nascendo e que já se alimentaram do húmus que os frutos passados deixaram fertilizar o chão...

"E assim, Gustavo, foi as CEBs. E as CEBs continuam. Mesmo acabando as coisas mais fortes. Pois antigamente eram muito fortes as CEBs, porque tinha muita reunião, tinha muito retiro por fora com todas as igrejas. Um pouco disso daí parou, mas as CEBs não pararam, não. Eles colocaram agora nome de 'Grupo de Rua', mas o nome mesmo é 'CEBs': 'Comunidades Eclesiais de Base'. Então, 'Grupo de Rua' também é bom, né, que é na rua que a gente faz o trabalho". (Margarida)

E nestes Grupos de Rua deve haver qualquer semente. Há. Os momentos de pedidos, durante as orações, quando quase todas as preocupações se voltam para vizinhos em dificuldades, não é uma esperança germinando? O que pode crescer daí? A insistência em largar a novela e se reunir durante a semana numa cidade, como diz João, cultivando espaço de convivência mesmo em meio ao individualismo exacerbado de nosso momento histórico, não é ponto de apoio para o amanhã?

Se temos a vivacidade da infância e o entusiasmo do momento efervescente das CEBs nas memórias, temos também, nesse terceiro momento de comparações e críticas, sinais da direção para onde se pode apontar adiante. Podemos lembrar, com Agnes Heller (2008), que os valores, uma vez desenvolvidos na humanidade, nunca se perdem completamente. E que o desespero e indignação de algumas pessoas e grupos face à desagregação de certos valores certos enriquecedores da essência humana que, em determinados momentos históricos, recuam - são eles mesmos também fontes de preservação de valores. Os grupos e pessoas que 
sustentam as ideias e práticas do Cristianismo da Libertação esperam ativamente por melhores condições de apresentarem ao mundo as sementes que plantaram em suas próprias vidas. 


\subsection{Memória e trabalho}

Ao lembrar dos trabalhos realizados durante a vida, os narradores, aqui, percorrem sentimentos, ideias, estados, reflexões com nuances variados. O trabalho na roça pode ser uma narrativa suada, misturada ao metabolismo das estações, colhida em muitas atividades que preenchem o dia, o ano, o crescimento do menino em homem.

"E aí a gente foi vivendo aquela vida sofrida. Eu lembro que com 4 anos eu já ia ajudar a apartar bezerro. Tinha uma vaquinha para dar leite lá. E depois, eu, com 7 anos, já ia para a roça. Com 7 anos. Ia limpar tronco de pé de café.

[...]

O meu pai ia plantar arroz também, e plantava com a máquina e o buraco ficava aberto, você ia com o pezinho atrás, ia tampando as covinhas. E aí, depois, comecei a ir para a escola, vinha da escola e ia para a roça. Vinha da escola e ia para a roça. Dia de sábado, a gente trabalhava até duas horas, uma hora da tarde. E depois da uma hora da tarde a gente ia rachar lenha.

$[\ldots]$

E depois ia ficando mais rapazinho, durante o domingo, na colheita de café, tinha que esparramar o café no terreirão, dava o sol, ficava mexendo, aí depois que amontoava, duas horas da tarde, estava quente, amontoava o café e botava ele quente para ir secando. Para ficar mais no ponto. Aí é que nós íamos passear, depois das duas horas da tarde.

E aí, rapaz, eu já estava apanhando café, abanava o café, para tirar os ciscos. Apanhava no saco, e aquele saco pesava sessenta, setenta quilos. E eu com doze anos, treze, já apanhava um saco de sessenta, setenta quilos nas costas, e ia levar até a carroça. Na colheita de café, a gente saía e ia, de madrugada. E tinha vezes que geava. Você chegava para abanar o café e tinha gelo por cima". (João)

Há também o orgulho e prazer das atividades realizadas na roça. O trabalho no campo não é sentido como oposto ao restante da vida. Viver e usufruir como parte do mesmo movimento. Talvez, trabalho sentido como totalização e não como amontoado de fragmentos antagônicos à atividade criativa de quem o realiza.

"Lá, meu pai era lavrador. A gente trabalhava de roça. Eu trabalhei muito de roça. A gente plantava mandioca. Porque lá no Norte a mandioca era de fazer farinha. Tinha a fábrica. Depois, pegava, arrancava a mandioca, levava lá na fábrica. Tinha as pessoas que descascavam a mandioca. Tinha as pessoas que ralavam a mandioca. Tinha as pessoas que 
ficavam na roda, que era de rodar pra poder sair a massa. Daquela farinha vinha a tapioca, da tapioca se fazia beijus. Aqueles beijus gostosos. E era uma vida assim...

Com todo mundo lá era assim. Lá se trocava o dia para uns fazerem numa semana e, depois, outros fazerem noutra semana. Então, aquela casa de farinha era do meu pai. Mas só que ele distribuía a todo mundo. Todo mundo tinha direito. E era assim.

\section{$[\ldots]$}

Depois, quando colhia todos aqueles mantimentos... era amendoim, era arroz, era algodão, era tudo quanto fosse de mantimento que era para desfrute, para alimentação do povo, a gente fazia. Aí, depois, ele guardava, depois vendia, e a renda dava para o dono lá. Tinha a renda dele.

\section{$[\ldots]$}

A roça eu adorava! Eu pegava numa enxada assim e parecia que eu era um homem. Eu trabalhava, e arrastava a enxada na roça, eu cavava, eu puxava, eu cavava buraquinho pra plantar milho, plantar todas as coisas, amendoim! Eu ajudava meu pai em tudo. Nós éramos muita gente. Meu pai botava a gente para ajudar na roça e a gente ia mesmo, de gosto!". (Margarida)

Mas o trabalho também pode ser indicador de desigualdade para quem lembra. Quando a distribuição dos empregos favorece certos grupos em detrimento de outros, as cisões da sociedade de classes começam a ficar mais evidentes. $\mathrm{O}$ pobre constata com amargor a estreita margem de opções de trabalho que lhe sobram.

"Quando eu fiz 14 anos - até arrumei um namorado -, eu olhei para a cidade, fiquei olhando o banco, os melhores empregos... Para quem eram? Filho de fazendeiro, filho do banqueiro, o filho do tenente, sabe. Aí, você ficava olhando aquelas meninas lindas que iam estudar em Penápolis, no colégio das irmãs, integral. Elas voltavam de férias para a cidade, assim bonitas. E a gente não tinha nada. Eu falava assim: 'Ah, não tem nada para mim aqui'.

Eu falei assim para a minha irmã: 'Vamos embora daqui. Vamos embora daqui porque aqui não tem nada. Porque aqui, ou a gente vai trabalhar a vida inteira de empregada doméstica, ou trabalhar na roça. Puxa, eu não quero isso para mim. Eu quero uma vida melhor"”. (Messias)

Imaginar um horizonte mais amplo de trabalho se liga à busca de uma vida mais realizada. Mas, para alguns, a saída da terra natal em direção às grandes cidades esbarra em frustrações. Encontram uma vida dura, sacrificada, com trabalhos cindidos entre grupos da sociedade. Dominação e opressão acompanham a trajetória de tantos trabalhadores pobres pelas trilhas da migração. As mulheres que saem do interior para alcançar outras 
possibilidades de trabalho além da roça e do emprego como domésticas podem se dar conta de que mesmo nas cidades maiores os trabalhos mais duros são empurrados para elas. O sonho do novo horizonte se contorce mas não se desfaz. Algumas lembranças se contam como decepção, amenizadas por um desfecho que frisa apreço pelo trabalho.

“Achei que a minha vida aqui não mudou muito da de lá, em termos de trabalho, né. Cheguei aqui, a gente tinha que trabalhar. Meus irmãos... um irmão meu trabalhava na Pirelli e o outro trabalhava na Volks. Mas, assim, a gente não tinha nada. Não tinha móveis, não tinha nada na casa. E meus irmãos, um trabalhava à noite, outro trabalhava durante o dia. Então, eu comecei a trabalhar também em casa de família aqui. Falei 'ai, meu Deus...'. Trabalhei. Mas eu gostava muito de trabalhar". (Madalena)

Deixando a vida sacrificada do campo, os trabalhadores carregam consigo a ampla gama de habilidades que desenvolveram. E se desdobram em muitas tarefas dentro e fora das firmas, chegando à exaustão. Os homens, por exemplo, dividem o trabalho de fábrica com a construção de suas próprias casas. E quando vem o desemprego, eles se viram nos mais variados bicos.

Para carregar o futuro nas costas e ir juntando seus blocos de felicidade um após o outro na nova cidade, o esforço é abastecido com esperança. As recordações dos sofrimentos da lida também podem iluminar a representação sobre si mesmo como forte, como resistente, como aquele que, crendo, fundou seu horizonte em alicerce bem cavado. As renúncias pesando tanto quanto o peso da confiança no devir. Equilíbrio que possibilitou aguentar os dias.

"Aí, em março, no dia 23 de março de 76, eu entrei na GM. Na General Motors. Comecei a trabalhar. Trabalhava de noite lá, chegava em casa três horas da manhã, dormia até as seis, seis e meia, e aí acordava e vinha lá do Jardim do Estádio - ia a pé - até aqui no Guaraciaba, com uma carriolinha, para tirar terra do terreno.

Ficava trabalhando aqui até 1 hora da tarde, sem comer nada. Aí, voltava lá em casa, cansado, chegava lá duas horas da tarde, fazia comida, comia três horas da tarde, e três e pouco eu já saía pra ir para a GM de novo. Entrava quatro e vinte na GM e ia trabalhar. Aí, eu não tinha dinheiro para sair num domingo, pra passear. E foi fazendo, fazendo, até levantar três cômodos aqui dentro.

[...]

E eu ia sempre construindo. A casa do meu pai, praticamente, foi quase tudo eu que fiz, rebocando, levantando. Trabalhava de noite na fábrica e de dia em casa, e vai, vai e vai. E não sobrava dinheiro nenhum. Eu fiquei cinco, seis anos, sem arrumar uma namorada. Era 
rapaz sem poder curtir porque eu não tinha dinheiro. Tudo o que eu ganhava na GM... de sábado que eu não trabalhava aqui, eu ia fazer hora extra na GM para poder ganhar dinheiro para pagar os materiais. Foi muito lutado mesmo...”. (João)

Marx, em seus Manuscritos econômico-filosóficos, analisava com indignação a maneira como os ideólogos do capitalismo consideravam as carências dos trabalhadores. Constatava como, para as teorizações econômicas, bastava que os trabalhadores reduzissem suas vidas à mera subsistência, considerando tudo o mais como luxo. A vida mais escassa possível deveria ser norma - para os trabalhadores, é claro. Desmascarando as teses dessa teorização capitalista, Marx desnudava o empobrecimento humano ao qual o trabalho sob o capital impunha àqueles que, contraditoriamente, produziam toda a riqueza material existente no mundo:

\begin{abstract}
A autorrenúncia, a renúncia à vida, a todas as carências humanas, é a sua tese principal. Quanto menos comeres, beberes, comprares livros, fores ao teatro, ao baile, ao restaurante, pensares, amares, teorizares, cantares, pintares, esgrimires etc., tanto mais tu poupas, tanto maior se tornará o teu tesouro, que nem as traças nem o roubo corroem, teu capital. Quanto menos tu fores, quanto menos externares a tua vida, tanto mais tens, tanto maior é tua vida exteriorizada, tanto mais acumulas da tua essência estranhada. Tudo o que o economista nacional te arranca de vida e de humanidade, ele te supre em dinheiro e riqueza. (MARX, 2010, p. 141, grifo do autor).
\end{abstract}

Com essa ironia e indignação, Marx propunha a sociedade dos indivíduos socialmente ricos, que supera a estrutura na qual seres humanos se reduzem à condição de trabalhadores ou capitalistas - e devolve, assim, a essência humana apropriada à vida efetiva das pessoas.

Mas contra o peso das condições massacrantes, as pessoas lembram e ressignificam a realidade. Engana-se quem pensa que há passividade. Como nos lembra José M. Gonçalves Filho (2003, p. 204, grifo do autor): "Resignação é o poder de ressignificar uma situação, quebrando o seu entendimento inercial". Aqui, a lembrança do dia-a-dia... o cansaço e a agressão do trabalho sobre o trabalhador. Quase nenhum trabalho é capaz de satisfazer o trabalhador que o executa. E quem conta o faz como quem se apropria de novo desta consciência.

“A GM é uma empresa boa e tudo. Mas me puseram para trabalhar lá fazendo geladeira. Era uma lã de vidro que coçava pra caramba. Nossa Senhora... Eu fiquei três meses 
sofrendo lá. Trabalhava pra caramba em linha de geladeira. Depois eu pedi para me tirarem. Acabou a geladeira, me transferiram para outro departamento, que lá fazia banco de carro. Aí, eu pedi para ser soldador, sem saber, sem nada, e o cara me passou para ser soldador sem saber nada. Na hora em que eu comecei a trabalhar, e achei ruim demais, eu falei: 'Não quero ser mais soldador'. E o cara falou: 'Não, agora você já está registrado. Se você não quer mais, então eu vou mandar você embora, mas você tem que ser soldador'. Aí, como eu estava precisando para a construção da casa ainda, fiquei de soldador. E aí começou a fazer mal para mim e eu fui transferido para os tornos automáticos. A fumaça, no óleo, subia, e aquilo lá ia para a cabeça. Era aquela solda MIG, e eu perdi muito cabelo na época. Caía muito cabelo, muita química". (João)

Algumas das lembranças ardem em chamas. A indignação e a revolta acompanham a fadiga. O patrão que assedia a empregada e a conformação da esposa ciente dos abusos. A patroa que fica passando o dedo nos móveis para checar a limpeza. E também as condições que, mesmo sem um outro ser humano como causador explícito, revelam mais uma vez a luta entre desiguais. Uns sofrem para dar o sangue e a vida na produção de que outros vão se apropriar como donos. Para trabalhadores, nenhum conforto. Como se além da subsistência mínima não precisassem de mais nada, nem mesmo de sono, espaço físico, movimento. $\mathrm{O}$ deslocamento para o trabalho já é um sacrifício: podem ser despejados nas firmas como peças descarregadas de um caminhão... ou trem. Messias lembra de forma contundente sua rotina entre trabalho, casa e, heroicamente, estudos:

“A gente não tinha liberdade para nada. Era trabalhar. Quem trabalha em fábrica, sabe: é muito duro, é terrível. Você é escravo. Você trabalha sete da manhã - a hora que eu entrava -, e saía vinte para as seis, para chegar na escola na segunda aula; para chegar em casa meianoite; levantar quatro e meia da manhã, para você tomar um banho de lata - que não tinha nem chuveiro naquela época -; pegar o ônibus cinco e vinte; o trem seis e dez da manhã, para entrar na fábrica às sete. Aqueles trens assim... lotados. Tinha dia que a gente saía pela janela. Quando não amassava suas marmitas e seus garfos. É vida? Não é, não. Até hoje é assim. É um trabalho escravo, sabe. Por isso que o pessoal, às vezes, se revolta. Se não houvesse essas lutas não haveria mais justiça”. (Messias)

Simone Weil, que assumiu a condição de operária entre as operárias, nos deixou reflexões, sentidas no corpo, sobre o estado em que trabalhadores padecem na sua rotina. Suas anotações inquietam pela fundura da ferida aberta no espírito a cada dia de trabalho: 
Mas de noite, depois de sair, e sobretudo de manhã, quando se vai para o trabalho e para o relógio de ponto, é duro pensar no dia que vai ser preciso percorrer. E no domingo à noite, quando o que se apresenta ao espírito não é um dia, mas uma semana inteira, o futuro é algo triste demais, esmagador demais, e o pensamento se curva. (WEIL, 1996, p. 160).

Esse massacre diário, infelizmente, tem sido a realidade de muitos trabalhadores. Mas quando operários se organizam nas firmas, quando as famílias dos trabalhadores se organizam em comunidade, quanta força de humanização isso tem! Que contraponto humanizador às pressões desumanizadoras do capital. As potencialidades de criação, de socialidade, a liberdade, a consciência, tudo aquilo que poderia estar soterrado sob o trabalho alienado emerge da vida vivida em comunidade, organizada para a alegria e o enfrentamento.

E a força de brotar, apesar da terra árida, faz essas potencialidades emergentes mais admiráveis. Das condições precárias saem sinais antecipadores da possível sociedade do futuro.

Dependendo das experiências que se mesclam com a rotina de trabalho, este pode ser também afetado e ressignificado. Sobre a secura das condições pode se derramar a esperança. Sobre o tempo repetitivo e linear se liga o tempo qualitativo, cósmico (cf. MARTINS, 1993). A memória do trabalho pode manifestar seu contraponto nas celebrações da vida. E a vida acabava por superar a perspectiva férrea do trabalho.

"Era diferente, era diferente. A gente se sentia assim... eu nem sei, assim... sentia vida mesmo, né, vida e alegria de poder estar ali lutando. E tinha umas músicas muito boas que a gente cantava, animava, esses cantos mesmo de protesto que a gente cantava. Dava mais um vigor. A gente ia no outro dia trabalhar, no mesmo trabalho, do mesmo jeito, mas assim, com mais esperança. Tinha mais esperança”. (Madalena) 


\subsection{Memória e totalização}

Quantas notas se confrontam e se harmonizam nas narrativas memoriais! Se fosse um instrumento musical, a memória certamente emitiria sons de acordes: um conjunto de notas distintas tocadas simultaneamente, formando um som que resulta de todas elas juntas. A beleza do acorde está nesse todo cujas partes se abraçam. É possível nomear cada uma delas, mas o que delas resulta só tem sentido por ser todas de uma só vez.

Ao narrar suas memórias, as pessoas tocam as notas de tempos, grupos, pessoas, influências, experiências e pensamentos diversos, todos se unindo na narrativa presente. $\mathrm{O}$ narrar se mistura à reflexão, à descrição, às comparações, às avaliações, ao passado e ao presente. A memória como totalidade revela uma variedade enorme de componentes em recíproca relação. Da mesma maneira, a própria memória é uma totalidade dentro de uma totalidade maior, que é a vida da pessoa, sua evolução no tempo.

Vejamos o exemplo emblemático de João lembrando de sua primeira participação numa greve de fábrica. Nesta lembrança, ele conta que chegou na GM para trabalhar sem saber de nada. Diz que não tinha ouvido falar sobre a greve iminente. Foi avisado de que estavam todos parados e não iriam trabalhar. Segue contando em detalhes, numa narrativa repleta de frescor, sua fuga da polícia pela Avenida Goiás. A seguir, reflete sobre sua própria narrativa:

"Ninguém estava fazendo nada, não tinha encrenca, era pacífico. A maioria estava lá de bobo, igual eu. Não sabia de nada. O sindicato lá de São Caetano sempre foi pelego, sempre foi sem-vergonha. Até hoje ainda é do lado do patrão. Fazia os acordos com o patrão. Enganava o peão. Aí, eu fui embora aquele dia. Disseram que não ia abrir. No outro dia, voltamos lá, aí deixaram entrar. (risos) Era tudo desorganizado. A gente não sabia nada. Não teve preparação. A gente estava que nem um Zé Mané, coitados, lá no meio dos outros, sem saber nada. Desorganizado. Se fosse hoje as coisas iriam ser bem diferentes".

Em sua reflexão, já emite um juízo sobre o sindicato de São Caetano. E dá uma dica: "se fosse hoje as coisas iriam ser bem diferentes". O que seria diferente? Talvez, o próprio João seria diferente. Por quê? Indícios de respostas:

"Em 81 deu outra greve, depois fracassou, mandaram 1.680 embora. Foi em 81. Então, o sindicato é aliado com o patrão lá em São Caetano. Não era o sindicato igual ao de São Bernardo. Em São Bernardo, não. Era um sindicato forte, bom. Que reconhecia o direito das pessoas, lutava, ficava do lado do povo. Na época do Lula. O Lula ficou até com o povão. Aquela época foi difícil...". 
Sua comparação entre os sindicatos de São Bernardo e de São Caetano vai delineando quais são suas referências para emitir o juízo sobre o "sindicato pelego" dentro de suas lembranças. E João informa a sequência de participações que foram se juntando à sua história de vida:

"Eu não estava no PT ainda. A greve foi antes. Depois dessas greves é que surgiu o PT. Aí, fui convidado. A minha entrada foi a participação na Igreja mesmo. Era grupo, eram pessoas de dentro da Igreja mesmo. Estava na igreja e me convidaram. Os trabalhadores de São Bernardo. 'Nós estamos fazendo um partido'. Era cara daqui que trabalhava em São Bernardo, na Volks".

Assim, ao narrar, podemos recorrer não apenas à lembrança do momento recordado, mas também a todas as demais influências que se seguiram ao longo da vida. Ao núcleo da memória retida do acontecimento passado se juntam as interpretações e avaliações que carregam os significados posteriores ao acontecimento. As memórias da participação na greve da GM podem ser, grosso modo, subdivididas da seguinte maneira:

1- Lembranças candentes dos fatos e sentimentos da época passada (sua chegada ingênua na fábrica, a fuga da polícia, o sentimento de medo durante a fuga);

2- Juízos sobre o acontecido (o sindicato de São Caetano era pelego, se fosse hoje seria diferente);

3- Referências das comparações e indícios das fontes de influência dos juízos (o sindicato de São Bernardo era bom, Lula estava com o povo, ingresso no PT).

A importância dos grupos que apóiam a memória e oferecem critérios para ressignificá-la confirmam o caráter de reconstrução daquilo que narramos ao lembrar. Reconstruímos o passado com os tijolos de várias épocas, grupos e experiências, desde o fato passado até o presente, passando por várias fases intermediárias. Como uma casa que revela as muitas camadas de construção ao longo do tempo. As casas da periferia são assim: vão se fazendo aos poucos, e o reboco novo se assenta sobre o bloco velho, aqui e ali revelando ainda as lacunas de massa fina que expõem o cimento, e cômodos que vão se anexando uns aos outros ao longo do tempo, sem nunca se concluir por completo, sendo o momento presente da casa, na verdade, a mistura de "muitas casas" se conectando para formar a que se vê.

Mas a imagem da casa ainda não é tão flexível quanto deveria ser a imagem do processo reconstrutor da memória. A cada nova influência, quem sabe, podem ser modificados todos os demais componentes que formam uma memória. Pingos de tinta numa palheta talvez sejam mais condizentes com o caráter da memória: cada fio de cor que se 
acrescenta modificando a tonalidade anterior e sendo modificada pela massa colorida à qual foi acrescentada, ambas se refazendo na palheta. E se assim se segue, vai-se criando um histórico de tintas variadas sempre fazendo emergir uma nova aparição. A dialética da relação entre as partes e o todo. Memória como processo em busca de sentido totalizante ou, como diria Ecleá Bosi (2003, p. 56), como "forma organizadora".

Sim, narramos e vamos organizando o sentido de nossas vidas. Revelamos a nós mesmos nossos percursos, antes mudos para nossa consciência. É assim que podemos identificar na infância características que dão sentido ao nosso caráter atual. Como Messias sobre sua postura frente aos estratos da sociedade:

"Mas eu sempre fui assim... essas ideias de líder, desde de criança. Eu acho que você tem já um... está dentro de você isso aí. Eu sempre lutei a favor de... eu estou sempre do lado de quem está precisando mais. Se é uma criança, se é um cachorro, se é um animal, se é um idoso, se é alguém doente, aí eu estou sempre do lado deste pessoal. Se eu vou numa festa e tem muita gente de classe média assim, eu não me sinto bem, sabe. Eu me sinto bem no meio do povo. Às vezes, a gente vai em algumas festas sociais, mas... os papos são diferentes. São outros papos, que não tem nada a ver com o que a gente imagina e pensa. Então, a gente não se dá bem. Acho que já vem da gente".

A infância narrada também pode nos cutucar algumas reflexões. Nelas, estão presentes os fortes laços comunitários entre os vizinhos: nas ajudas mútuas de roça, nos terços revezados entre casas, nas rodas de causos e de cantoria. Também há a lembrança da alegria da família reunida, da partilha do pão entre os irmãos. Quantos destes aprendizados comunitários podem ser identificados na formação das relações posteriores entre vizinhos de bairro já na cidade, nos grupos da Igreja, nas organizações populares urbanas? E a memória vai tecendo essas tantas dicas de sentido.

Muitas experiências vão sendo ligadas, uma a uma, nas memórias. Histórias de vida que caminham para a totalização. A cada trecho a narrativa-pincel vai desenhando lembranças que se articulam ao que foi narrado e novas paisagens surgem no quadro total do sentido. Sempre um quadro em formação. Vemos a obra destes artistas em curso, e cada traço surpreende o outro, revelando-se mutuamente.

João, mais uma vez, nos dá a conhecer os processos da arte de narrar como totalização:

"Eu na Igreja, antes, era descomprometido. Eu ia na igreja, rezava a missa. Rezar não, eu assistia, né. Não tinha muita participação. Eu assistia a missa. Depois que eu vim para cá, assistia a missa também. Mas depois de 79, em que um jovem me convidou para participar da 
igreja, no grupo de teatro, e que eu aceitei o convite, eu já não assisti só mais, eu comecei a participar. Houve uma mudança muito grande. Aí, eu comecei a perceber que eu tinha compromisso. Não era só ir lá assistir a missa e ir embora. Que eu tinha alguma coisa a ver com a sociedade. Eu tinha que ter mais envolvimento com as pessoas. Tinha muitas pessoas que não participavam da Igreja, e a gente precisava levar o Evangelho até essas pessoas. Mudou cem por cento. Mudou pra caramba".

Não bastou se mudar do Paraná para São Paulo, ele mudou a sua participação na Igreja. E isso implicou num novo compromisso, não apenas eclesial, mas social e político. Mudança de fé - de sua estrutura de valores -, mudança de concepção de Deus - fé religiosa -, mudança de consciência, mudança de vida. A mudança de um aspecto tem repercussão no todo, muda o todo.

"Mudou bastante a minha forma de enxergar Deus. A gente vê uma forma diferente. E eu só ia lá pedir perdão pelos pecados que eu tinha cometido na semana. E aí, depois que eu comecei a minha participação, eu já me comprometia mais. Eu ia vendo. Eu comecei a perceber que, diante de Deus, eu não estava fazendo nada. Pelo que Ele pedia no Evangelho, eu estava de braços cruzados. Eu tinha que fazer, eu tinha que me mexer, era hora de eu fazer alguma coisa. Então, você se sentia tocado. 'Ou você vai ou você não está fazendo parte'. Aí, você tinha que ir. (risos)

Aí, é quando começa a participação, a minha infiltração na política, no PT. Não era porque o PT era dos metalúrgicos nem nada, mas era um partido mais comprometido com a sociedade. É um partido do povo mais sofrido. É um partido que foi criado com a ideologia diferente dos outros". (João)

Aqui, João nos explicita a implicação da fé na adesão partidária. Esta fé que modificou a consciência e o moveu a uma adesão de visão de mundo, de valores. Estar ativamente do lado da classe trabalhadora como fruto da autoconsciência revela as múltiplas relações dialéticas entre as esferas da vida. Adesão de fé e adesão política que vão se nutrindo reciprocamente. Alimento mútuo que modifica a seiva uma da outra.

$\mathrm{Na}$ força formadora dos grupos aos quais os narradores pertenceram - ou ainda pertencem - denota-se parte importante dessas relações recíprocas que formam o todo de suas vidas. Madalena vai contando suas participações, seus grupos, e as implicações destes no sentido da sua trajetória. Ela lembra que passou por uma crise brava enquanto estava no convento. Ver a pobreza das famílias atendidas pela creche de sua congregação em contraste com o conforto do convento tornou-se cada vez mais difícil de engolir. E a valoração da situação teve como referências os grupos dos quais já tinha feito parte ou entrado em contato. 
Sindicatos durante as greves, ACO, CEBs, foram alguns dos grupos presentes na realidade que Madalena vivenciava antes de ir para o convento. A forma de atuar e a adesão éticopolítica destes grupos; a opção pelos pobres dos grupos ligados à Igreja, na esfera do Cristianismo da Libertação, em que esta opção é fundamentalmente a dos pobres, para os pobres e com os pobres, numa organização tendente à horizontalidade; as mobilizações nos bairros, articulando diversos movimentos e pastorais; as práticas efetivas destes grupos, mobilizados e em constante efervescência para melhorar concretamente as condições de vida; tudo isso exala dos grupos, numa dialética em que as pessoas formam e delineiam o coletivo e são marcadas também por essa mesma dinâmica da qual participam ativamente.

Todo esse ambiente psicossocial já permeia a vida de Madalena antes de sua ida para o convento. Quando se depara com a realidade dos pobres de Petrópolis, arde um incômodo que vai tomando vulto em questionamentos fundados na maneira de enxergar as desigualdades e de vislumbrar modos de enfrentá-las. Os grupos de sua referência dão-lhe o discernimento da situação e a força para se posicionar pessoalmente.

“Aquilo foi me dando uma dor no coração... Tinha criança que os pais deixavam lá, esqueciam lá, não iam buscar. Daí, a gente tinha que ficar dormindo com as crianças lá na creche. Ai... eu fui ficando assim sabe... foi me dando uma tristeza, e eu ficava pensando assim: 'O que é que eu estou fazendo aqui? Essas freiras não fazem nada. Só ficam na creche. Mas e agora? A gente tem que fazer alguma coisa, é impossível não ter o que fazer'”. (Madalena)

A decisão se condensa dentro de Madalena. Ela se dirige à freira superior:

"Daí falei: 'Ah, irmã, não vou ficar aqui, não. Não dou conta de ficar aqui. Eu acho que Deus me quer em outro lugar, mas não aqui. Eu tenho que lutar com o povo. Eu venho de uma comunidade onde a gente luta, onde a gente conquista as coisas para as pessoas, para o povo. E aqui a gente não faz nada. Fica só aqui, só dentro desse convento aqui, ó. Bons dentistas, bons psicólogos, bons tudo, e eu acho que está errado"”. (Madalena, grifo nosso)

Ali está a comunidade solidária, de luta, presente na ebulição que movia Madalena à coerência de vida que tanto a interpelava. Os movimentos e o povo da região da São Geraldo ardendo no coração de Madalena, dando uma imagem forte para comparar com a situação observada no convento.

O quadro histórico no qual Madalena se insere - e os grupos com os quais teve proximidade ou esteve diretamente envolvida, no final dos anos 70 e início dos 80 -, congrega algumas características que também devem ser levadas em conta. No contexto da crise do sistema político populista e do agravamento da contradição entre classes no qual estava 
inserido o Brasil, diversos setores da Igreja Católica passaram a se envolver nos conflitos sociais, desde pelo menos o início dos anos 60. Os leigos vêm de um processo no qual ganham cada vez mais destaque dentro da Igreja. Por conta da repressão durante a ditadura em curso, a Igreja torna-se praticamente o único espaço de participação, e articula grupos organizados politicamente com os fiéis. O mesmo acontece nos bairros, onde o povo consegue maior espaço de atuação do que nas fábricas, estas altamente visadas pela repressão. Assim, o encontro de movimentos populares em ascensão, militantes sindicais e partidários - mesmo que clandestinos - com a Igreja, são parte da matriz que forma os grupos de referência de Madalena. Ainda que seja apenas um recorte dos complexos fatores políticos, sociais, econômicos, culturais que marcam esse período, a descrição serve para tirar da suspensão tais grupos e vislumbrar o quadro histórico no qual se desenvolvem.

Maurice Halbwachs (2004) relaciona o ambiente social à elaboração das memórias. Para ele, as influências recíprocas dos membros de um grupo inspiram ideias, pensamentos, reflexões, emoções que vibram em uníssono, sendo difícil delimitar o ponto que separa esses elementos como sendo exclusivamente originados em cada um de nós e como sendo parte das influências do grupo.

Mas os grupos não apenas costumam ser múltiplos simultaneamente na vida de uma pessoa como também se diversificam ao longo do tempo. Por exemplo: num dado período da vida, fazemos parte do grupo de amigos na escola, do grupo de vizinhos, da família etc., e todos no mesmo período. Ao longo da vida, deixamos o grupo da escola, permanecemos no grupo da vizinhança, adentramos no grupo de colegas de trabalho, e assim por diante. Ou seja, a partir dos nossos grupos atuais e dos que já fizemos parte no passado, podemos tatear algumas influências que se articulam no modo como elaboramos nossa memória.

A cada uma dessas influências, concebemos que uma outra se oponha, acreditamos que nosso ato é independente de todas essas influências, ainda que não esteja sob a dependência exclusiva de nenhuma delas. Então nos damos conta de que na verdade ele resulta de seu conjunto e está sempre dominado pela lei da causalidade. Aqui, da mesma forma, como a lembrança reaparece em função de muitas séries de pensamentos coletivos emaranhados e porque não podemos atribuí-la exclusivamente a nenhuma, imaginamos que é independente delas e contrapomos sua unidade à sua multiplicidade. É como acreditar que um objeto pesado, suspenso no ar por 
uma porção de fios tênues e entrecruzados, permaneça suspenso no vazio, e ali se sustenta. (HALBWACHS, 2004, p. 70).

Madalena reflete sobre o papel de alguns grupos na sua formação integral. Após evocar grupos como as CEBs, a Irmandade do Servo Sofredor, a equipe de catequese, o Grupo de Jovens, entre outros, chega à conclusão de que deve a estas participações a direção de sua caminhada e de sua própria face, transfigurada por essas experiências fundadoras.

"Hoje, eu posso dizer, assim, com louvor e alegria: não sou apegada a nada. E isso eu aprendi mesmo, na irmandade, nas CEBs". (Madalena)

E credita aos grupos de que participou o desenvolvimento de sua calma e pacifismo.

“Antigamente, se alguém falasse alguma coisa de mim, ah, eu já ia com quatro pedras na mão. Eu não queria nem escutar se era verdade ou se não era. Já ia estourando, e xingando e brigando e tudo. Agora, hoje não. Então, hoje eu vou na paz, sem violência, na tranqüilidade. Eu penso que isso foi uma coisa que eu aprendi, que mudou. Precisei passar por CEBs, pela Irmandade, pela catequese, para poder mudar”.

Narrando suas memórias, cada pessoa pode se dar conta de si mesma e de todos os outros. Nota o quanto interveio na realidade, o quanto contribuiu para a formação de pessoas, para a modificação de circunstâncias. Percebem que "valeu a pena" e sentem "saudade", expressão e palavra tão constantes nas narrativas. Começam a lembrar, desde a infância. Aos poucos, vão buscando não apenas evocações mas também sentido. Revelam para quem ouve e para si mesmas a profunda interconexão entre todas as esferas e partes da realidade. Grupos, bairro, momento histórico, classe social, experiências diversas, atmosferas subjetivas, pressões sociais, abertura para criar e ser criado, mover e ser movido, formar e se formado. Tudo formando o todo. O todo dando sentido a cada parte.

E assim, podem ir aflorando conclusões acerca do trabalho de lembrar:

"Esse negócio que você está fazendo comigo, esta entrevista, está sendo bom. Porque eu estou tendo a oportunidade de me abrir e contar o meu passado. Sabe como está sendo? Você vai numa formação. Você escreve na formação, tá, e fecha o caderno. Aí, outro dia você vai na reunião. Você faz a reunião, tal, e escreve tudo lá e fecha o caderno. E vai indo, vai indo, desse jeito, sabe. Você nunca abre o caderno para ver aquele dia, o conteúdo daquela reunião. Você nunca vê isso aí, o que foi falado, o que teve naquela formação. Você não abre mais o caderno para ver o que aconteceu naquela formação, o que tinha lá, o que foi colocado. E isso aí que eu estou passando para você, é uma forma de eu te abrir esse caderno. Ter aberto de novo e lembrado... não tudo, mas parte, o mais marcante. A parte que mais me marcou. 
Isso, para mim, foi muito gratificante. Essas três noitadas que a gente teve... (risos) Você me entrevistando, é uma forma de eu me abrir. Não só contar negócio da Igreja, mas da minha vida também". (João)

Os cadernos vão sendo reabertos. O que se encontra lá dentro? O passado? Talvez o futuro. O que foi ressignifica o presente quando é lembrado. Liberta a esperança que estava guardada. "A nostalgia revela sua outra face: a crítica da sociedade atual e o desejo de que o presente e o futuro nos devolvam alguma coisa preciosa que foi perdida." (BOSI, 2003, p. 67). Vale a pena deixar Madalena dizer novamente o que exclamou lá atrás:

"Nossa, voltei ao passado! (risos) Você viu, estou até mais animada, né. Nossa, dá um ânimo na gente, a gente lembrar de tudo isso. Que a gente tinha FORÇA para fazer tudo isso. Hoje acho que não tem mais. Mas a gente se anima. Só de pensar a gente se anima. É um ânimo novo. Uma vida nova. E eu fico feliz com tudo isso. Tanta coisa boa já aconteceu, e vai acontecer, com certeza, na vida do povo. Para construir essa história. Continuar a vida em Deus". (Madalena)

A memória só é possível porque continua sendo significativa hoje, agora. Convergem as notas. Messias ressoa seu acorde:

"Foi fácil lembrar. Porque é uma coisa presente na sua vida. Não é porque você está parado, que você não está atuando... essas coisas não morrem".

Não morrem, pelo contrário, vivificam. Ouvi de uma das pessoas algo muito bonito, após mais um encontro para revisar narrativas e rememorar junto com sua família: "hoje eu até renasci, não de corpo, que está velho, mas de espírito”. E as memórias nas duas pontas do vento, esvoaçando o cheiro do tempo, tocando as coisas antigas e novas, refundando o "lá" do devir. Como Margarida, que vê sua vida brotar do que foi para o adiante:

"Vai longe ainda, Gustavo. Vai longe...". 


\section{REFERÊNCIAS CITADAS}

AMATUZZI, Mauro M. Religião e sentido de vida: um estudo teórico. In: Temas em Psicologia, vol. 7, nº 2, 183-190, 1999.

ANIZAN, Jean-Émile. [homilia a Charonne] Glória a Jesus que se fez operário. Trad.: José Mahon, s/d. (Manuscrito).

ASCH, Solomon. Psicologia Social. São Paulo: Editora Nacional, 1977.

BENJAMIN, Walter. Magia e técnica, arte e política: ensaios sobre literatura e história da cultura. São Paulo: Brasiliense, 1994. (Obras escolhidas, v. 1).

BÍBLIA DE JERUSALÉM. $3^{\mathrm{a}}$ impressão. São Paulo: Paulus, 2004.

BLEGER, José. Temas de psicologia: entrevista e grupos. São Paulo: Martins Fontes, 1980.

BOFF, Clodovis. Comunidade eclesial comunidade política - ensaios de eclesiologia política. Petrópolis: Vozes, 1978.

BOFF, Leonardo. Vida para além da morte. Petrópolis: Vozes, 1991.

Eclesiogênese: a reinvenção da Igreja. Rio de Janeiro: Record, 2008.

BOSI, Ecléa. Memória e sociedade: lembranças de velhos. 3. ed. São Paulo: Companhia das Letras, 1994.

Editorial, 2003.

O tempo vivo da memória: ensaios de psicologia social. São Paulo: Ateliê

CANDIDO, Antonio. Os parceiros do Rio Bonito: estudo sobre o caipira paulista e a transformação dos seus meios de vida. São Paulo: Duas Cidades: Ed. 34, 2001.

DARMEGIAN, Sueli. Para além da barbárie civilizatória: o amor e a ética humanista.

São Paulo: Casa do Psicólogo, 2009.

DUSSEL, Enrique. Ética Comunitária. Petrópolis: Vozes, 1986.

Paulinas, 1997.

Oito ensaios sobre cultura latino-americana e libertação. São Paulo:

Teologia da libertação e marxismo. In: LÖWY, Michael (Org.). O

Marxismo na América Latina. São Paulo: Fundação Perseu Abramo, 1999.

ENGELS, Friedrich; MARX, Karl. A ideologia alemã. São Paulo: Expressão Popular, 2008.

FARFÁN, Nicolás. La memoria como clave para superar el marasmo. In: SALAS, Julio R. J. (Compilador). Memória, silencio y acción psicosocial: reflexiones sobre por qué recordar em Colombia. Bogotá-Colômbia: Cátedra Libre, 2010. 
FILHO, José Moura Gonçalves. Problemas de método em Psicologia Social: algumas notas sobre a humilhação política e o pesquisador participante. In: BOCK, Ana Mercês Bahia (Org.). Psicologia e compromisso social. São Paulo: Cortez, 2003.

Humilhação social: humilhação política. In: SOUZA, Beatriz de Paula (Org.). Orientação à queixa escolar. São Paulo: Casa do Psicólogo, 2007. p. 193239.

FROMM, Erich. Análise do Homem. São Paulo: Círculo do Livro, s/d.

Da desobediência e outros ensaios. Rio de Janeiro: Zahar, 1984.

GOLDMANN, Lucien. Ciências humanas e filosofia: que é a sociologia? São Paulo:

Difusão Européia do Livro, 1970.

HALBWACHS, Maurice. A memória coletiva. São Paulo: Centauro, 2004.

HELLER, Agnes. Teoria de las necesidades en Marx. Barcelona: Penisula, 1986.

O cotidiano e a história. São Paulo: Paz e Terra, 2008.

JACOBI, Pedro; NUNES, Edison. Movimentos populares urbanos, poder local e conquista da democracia; In: MOISÉS, José Álvaro et al. Cidade, povo e poder. Rio de Janeiro: Paz e Terra, 1982.

KONDER, Leandro. O que é dialética. São Paulo: Editora Brasiliense, 1987.

KOSIK, Karel. Dialética do concreto. 2. ed. Rio de Janeiro: Paz e Terra, 1976.

LÖWY, Michael. Guerra dos deuses: religião e política na América Latina. Petrópolis: Vozes, 2000.

LUKÁCS, Georg. História e consciência de classe. São Paulo: Martins Fontes, 2003.

MADURO, Otto. Religião e luta de classes: quadro teórico para a análise de suas interrelações na América Latina. Petrópolis: Vozes, 1981.

MAHFOUD, Miguel. Folia de Reis: Festa Raiz ou Experiência Religiosa em Comunidades da Estação Ecológica Juréia-Itatins na perspectiva da Psicologia Social Fenomenológica. 1996. Tese (Doutorado em Psicologia Social) - Instituto de Psicologia, Universidade de São Paulo, São Paulo, 1996.

MARTINS, Heloisa H. T. de Souza. Igreja e movimento operário no ABC: 1954-1975. São Paulo: Hucitec; São Caetano do Sul: Prefeitura de São Caetano do Sul, 1994.

MARTINS, José de Souza. A aparição do demônio na fábrica, no meio da produção. In: Tempo Social; Rev. Sociologia USP, São Paulo, 5(1-2): 1-29, 1993.

MARX, Karl. Manuscritos econômico-filosóficos. São Paulo: Boitempo, 2010. 
MEDICI, Ademir. Migração, urbanismo e cidadania - a história de Santo André contada por seus personagens. Santo André: Prefeitura Municipal de Santo André, 1992.

MEIHY, José Carlos Sebe Bom. Manual de história oral. São Paulo: Loyola, 1996.

MÉSZÁROS, István. A teoria da alienação em Marx. São Paulo: Boitempo, 2006.

A educação para além do capital. 2. ed. São Paulo: Boitempo, 2008.

Estrutura social e formas de consciência: a determinação social do

método. São Paulo: Boitempo, 2009.

NISBET, Robert A. Comunidade. In: FORACCHI, Marialice Mencarini; MARTINS, José de Souza. Sociologia e sociedade: leituras de introdução à sociologia. Rio de Janeiro: LTC, 1977.

PELLEGRINO, Hélio. Édipo e a paixão. In: CARDOSO, Sérgio et al. Os sentidos da paixão. São Paulo: Companhia das Letras, 1987.

POGIBIN, Guilherme Gibran. Memórias de metalúrgicos grevistas do ABC paulista. 2009. Dissertação (Mestrado em Psicologia Social) - Instituto de Psicologia, Universidade de São Paulo, São Paulo, 2009.

PRETI, Dino (Org.). Análise de textos orais. 6. ed. São Paulo: Humanitas Publicações FFLCH/USP, 2003.

RIBEIRO, Karen. Os padres operários nas lembranças de uma comunidade: um estudo de memória e prática política. 2003. Dissertação (Mestrado em Psicologia Social) Instituto de Psicologia, Universidade de São Paulo, São Paulo, 2003.

ROSA, Guimarães. Grande sertão: veredas. 19. ed. Rio de Janeiro: Nova Fronteira, 2001.

SÁ, Celso Pereira de. Sobre o campo de estudo da memória social: uma perspectiva psicossocial. Psicologia: Reflexão e Crítica, Porto Alegre, v. 20, n. 2, 2007.

SEGUNDO, Juan Luis. A história perdida e recuperada de Jesus de Nazaré: dos sinóticos a Paulo. São Paulo: Paulus, 1997.

TEIXEIRA, Faustino. A gênese das CEBs no Brasil: elementos explicativos. São Paulo: Paulinas, 1988.

THOMPSON, Paul. A voz do passado: história oral. Rio de Janeiro: Paz e Terra, 1992.

WEIL, Simone. A condição operária e outros estudos sobre a opressão. Seleção e apresentação de Ecléa Bosi. Rio de Janeiro: Paz e Terra, 1996. 


\section{REFERÊNCIAS CONSULTADAS}

ALMEIDA, Juracy Armando M. Marxismo e subjetividade. Psicologia Revista, São Paulo, n.6, p. 145-154, maio/1998.

ARENDT, Hannah. Entre o passado e o futuro. São Paulo: Perspectiva, 2007.

A condição humana. Rio de Janeiro: Forense Universitária, 2008.

BETTO, Frei. O que é Comunidade Eclesial de Base. São Paulo: Brasiliense, 1985.

BOFF, Clodovis; BOFF, Leonardo. Da libertação: o sentido teológico das libertações sócio-históricas. Petrópolis: Vozes, 1979.

BOFF, Leonardo. Teologia do cativeiro e da libertação. Petrópolis: Vozes, 1980.

A fé na periferia do mundo. Petrópolis: Vozes, 1986.

BOGO, Ademar. Identidade e luta de classes. São Paulo: Expressão Popular, 2008.

BOSI, Ecléa. Entre a opinião e o estereótipo. Novos estudos CEBRAP, no 32, p. 111-118, mar/1992.

BOUCHAUD, Joseph; KUNZ, Frédy. A burrinha de Balaão numa favela brasileira. São Paulo: Loyola, 1977.

BOURDIEU, P. (Org.). A miséria do mundo. Petrópolis: Vozes, 1999.

BRANDÃO, Carlos Rodrigues. Memória/sertão - cenários, cenas, pessoas e gestos nos sertões de João Guimarães Rosa e de Manuelzão. São Paulo: Editorial Cone Sul: Editora da Universidade de Uberaba, 1998.

BRANT, Vinícius Caldeira; SINGER, Paul. (Orgs.). São Paulo: o povo em movimento. Petrópolis: Vozes, 1982.

CARONE, Iray. Necessidade e individuação: subsídios teóricos para uma psicologia social marxista. São Paulo, 1990. 53p. Relatório técnico.

A questão dos paradigmas nas ciências humanas e o paradigma da estrutura das objetivações sociais de Agnes Heller. In: LANE, S. T. M.; SAWAYA, B. B. (Orgs.). Novas veredas da psicologia social. São Paulo: Brasiliense, 1995. p. 11-21.

CHATAWAY, C. J. Negotiating the Observer-observed relationship: participatory action research. In: Tolman, D. \& Brydon-Miller, M. (Orgs.). From subjects to subjectivities - a handbook of interpretative and participatory methods. USA: New York University Press, 2001.

DELGADO, Lucilia de Almeida Neves. História oral: memória, tempo, identidades. Belo Horizonte: Autêntica, 2006. 
DEMO, Pedro. Introdução à metodologia da Ciência São Paulo: Atlas, 1985.

FILHO, José Moura Gonçalves. Passagem para a Vila Joanisa: uma introdução ao problema da humilhação social. 1995. Dissertação (Mestrado em Psicologia Social) Instituto de Psicologia, Universidade de São Paulo, São Paulo, 1995.

FROCHTENGARTEN, Fernando. Memórias de vida, memórias de guerra: um estudo psicossocial sobre o desenraizamento. São Paulo: Perspectiva: FAPESP, 2005.

GOLDMANN, Lucien. A criação cultural na sociedade moderna. São Paulo: Difusão Européia do Livro, 1972.

HAGUETTE, Teresa Maria Frota. Metodologias qualitativas na sociologia. Petrópolis: Vozes, 1987.

HIRANO, Sedi (Org.). Pesquisa social: projeto e planejamento. São Paulo: T. A. Queiroz, 1979.

IASI, Mauro Luis. Ensaios sobre consciência e emancipação. São Paulo: Expressão Popular, 2007.

KUNZ, Frédy. À sombra de Nabuco. São Paulo: Loyola, 1997.

LA BOÉTIE, Étienne de. Discurso da servidão voluntária. São Paulo: Martin Claret, 2009.

LÖWY, Michael. Marxismo e Teologia da Libertação. São Paulo: Cortez, 1991.

MARGARETE, Irmã; KUNZ, Fredy; VICENTE, Zé. Sangradouro: nascido da seca nordestina: 1979-1984. São Paulo: Loyola, 1985.

MAHFOUD, Miguel; SCHIMIDT, Maria Luisa Sandoval. Halbwachs: memória coletiva e experiência. Psicologia USP, São Paulo, v. 4, n. 1/2, 1993. p. 285-298.

MAINWARING, Scott. Igreja Católica e a política no Brasil (1916-1985). São Paulo: Brasiliense, 2004.

MARX, Karl. Teses sobre Feuerbach. In: ENGELS, Friedrich; MARX, Karl. A ideologia alemã. São Paulo: Expressão Popular, 2008.

MELLO, Sylvia Leser. Trabalho e sobrevivência: mulheres do campo e da periferia de São Paulo. São Paulo: Ática, 1988.

MENDONÇA, Sonia Regina de. História do Brasil recente: 1964-1992. $5^{\text {a }}$ Ed. São Paulo: Ática, 2006.

OLIVEIRA, Paulo de Salles. Vidas compartilhadas: cultura e co-educação de gerações na vida cotidiana. São Paulo: Hucitec: FAPESP, 1999.

QUEIROZ, José J.; VALLE, Edênio (Orgs.) A cultura do povo. São Paulo: Cortez, 1988. 
SILVA, Cândido da Costa e. Roteiro da vida e da morte: um estudo do catolicismo no sertão da Bahia. São Paulo: Ática, 1982.

SIMMEL, Georg. A metrópole e a vida mental. In: VELHO, Otávio G. (Org.). O fenômeno urbano. Rio de Janeiro: Zahar Editores, 1967. 


\section{APÊNDICES}

\section{APÊNDICE A - Roteiro-piloto de entrevista}

\section{Infância e juventude}

- Onde nasceu e foi criado(a)?

- Quais eram as atividades de sua família durante sua infância e juventude?

- Como começou a participar das atividades de Igreja?

\section{Participação e dinâmica das CEBs}

- Como você começou a participar das CEBs?

- Como funcionavam as atividades das CEBs?

- Como são/eram, em geral, as reuniões de CEBs? E os encontros maiores (Intereclesiais, Seminários de Formação, Seminários Regionais/Interdiocesanos, Encontros)?

- Você é/foi animador(a) de grupo? Como começou a ser animador(a)? Como é/foi ser animador(a)?

\section{CEBs e a cidade de Santo André}

- Como foi sua chegada a Santo André?

- Como era a região quando você chegou?

- Quais eram os principais problemas da região?

- Você se lembra de como vocês se organizavam para lidar com os problemas da região?

- Conte-me como foi a participação de vocês para lidar com este problema da região. (fazer isso com cada um dos principais problemas citados)

- Quais atividades (como encontros, reuniões, passeatas, reivindicações, apoios, festas, entre outros) foram mais marcantes para você? Conte-me como foram.

\section{CEBs e o trabalho}

- Quais foram suas ocupações ou trabalhos profissionais ao longo da vida? Como você se sentia nestes trabalhos/atividades?

- Nas atividades das CEBs tratava-se dos trabalhos profissionais de cada um? Como?

- Você participou de grupos que atuavam na empresa? Quais grupos? Como foi sua atuação nestes grupos? 


\section{CEBs, comunidade e cotidiano}

- As CEBs tratavam da vida cotidiana? Como?

- Como vocês se relacionavam nas CEBs? Teve amigos(as)?

- Quais foram seus papéis dentro das CEBs durante sua trajetória?

- De quais grupos já participou na comunidade, além das CEBs? Como é/foi o trabalho em cada um destes grupos?

- Você já sofreu algum tipo de discriminação por participar das atividades das CEBs?

- Você já sofreu algum tipo de repressão por participar das atividades das CEBs?

\section{CEBs e a Igreja}

- Como era a religiosidade para você antes de entrar nas CEBs? E depois de entrar?

- Houve apoio de padres e bispos para as atividades das CEBs? Como era esse apoio?

- Houve resistências de padres e bispos para as atividades de CEBs? Como foi esta resistência?

\section{Sínteses}

- O que o motivou a fazer tudo o que fez nas CEBs? O que o levou a fazer?

- O que você aprendeu com a participação nas CEBs?

- Há algo de que se arrepende na participação dentro das CEBs?

- Ter participado das CEBs mudou algo na sua vida? E na vida das outras pessoas?

- De que mais gostou ou tem gostado de fazer nas atividades de CEBs? O que gostaria de reviver? Por que?

- Como você avalia as CEBs do passado? E as CEBs de hoje?

- Como você se sentiu nestas nossas conversas sobre sua trajetória nas CEBs? 


\section{APÊNDICE B - Roteiro de entrevista}

\section{Infância e juventude}

- Origem.

- Vida familiar, atividades familiares, condições de vida durante infância e juventude.

- Atividades religiosas na infância e juventude.

\section{Participação e dinâmica em grupos religiosos, sociais e políticos}

- Participação em grupos religiosos, sociais e políticos.

- Início de participação nas CEBs.

- Dinâmicas de atividades e encontros nos Grupos de Rua e nos encontros maiores

(Intereclesiais, Seminários de Formação, Seminários Regionais/Interdiocesanos, Encontros) de CEBs e de outros grupos.

- Papéis ocupados nos grupos dos quais participou.

\section{A cidade de Santo André}

- Chegada a Santo André.

- Lembranças da região quando chegou.

- Principais problemas da região à época.

- Lembranças da organização e das participações para lidar com os problemas da região.

- Atividades marcantes (como encontros, reuniões, passeatas, reivindicações, apoios, festas, entre outros).

\section{O trabalho}

- Ocupações ou trabalhos profissionais ao longo da vida.

- Lembranças da relação entre a dinâmica dos encontros (de CEBs e outros grupos) e os trabalhos profissionais de cada um.

- Participação em grupos/movimentos que atuavam no trabalho.

\section{Comunidade e cotidiano}

- Questões cotidianas nos encontros (de CEBs e outros grupos).

- Relacionamentos e amizades.

- Formas de participação na comunidade.

- Possibilidades de discriminação e/ou repressão por participar das atividades. 


\section{Religiosidade e Igreja}

- Religiosidade antes de entrar nas CEBs.

- Religiosidade depois de entrar nas CEBs.

- Reações de apoio e/ou resistência por parte de padres e bispos.

\section{Sínteses e reflexões}

- Aprendizados com a participação nas CEBs e em outros grupos.

- Arrependimentos na participação.

- Percepção de mudanças na própria vida e na vida de outras pessoas relacionadas às participações.

- O que gostaria de reviver.

- Avaliação das CEBs do passado e das CEBs de hoje.

- Reflexão sobre os encontros, as conversas, para narrar estas memórias. 


\section{APÊNDICE C - Modelo de Termo de Consentimento \\ TERMO DE CONSENTIMENTO LIVRE E ESCLARECIDO}

Você está sendo convidado(a) a participar, como voluntário(a), em uma pesquisa. Após ser esclarecido(a) sobre as informações a seguir, no caso de aceitar fazer parte do estudo, assine ao final deste documento, que está em duas vias. Uma delas é sua e a outra é do pesquisador responsável.

1- Serão realizadas entrevistas como parte da pesquisa de mestrado, sob orientação da professora Sueli Damergian, tendo como objetivo registrar e analisar as memórias das pessoas que participaram e/ou participam de Comunidades Eclesiais de Base.

2- As entrevistas dependerão de sua disponibilidade e serão gravadas em áudio, sendo que as gravações ficarão arquivadas com o pesquisador Gustavo Xavier.

3- Vale salientar que a participação é voluntária e a entrevista pode ser interrompida a qualquer momento. Além disso, a qualquer momento você poderá desautorizar o uso de parte ou de todo o material.

4- O sigilo está garantido e sua identidade não será revelada, salvo por solicitação de sua parte e certificada num novo Termo de Consentimento.

5- O material coletado na pesquisa poderá ser utilizado em uma futura publicação em livro e/ou revista científica ou publicação relacionada ao universo das Comunidades Eclesiais de Base, como publicações de movimentos sociais ou grupos religiosos, respeitando estritamente o sigilo e sem revelar sua identidade.

6- A pesquisa não trará nenhum risco a você e nem oferecerá vantagem financeira.

Qualquer dúvida, entrar em contato com Gustavo Xavier pelo telefone (11) 3705-0067 / (11) 9817-9380, ou e-mail guxav@yahoo.com.br, ou diretamente no Comitê de Ética em Pesquisa com Seres Humanos do IPUSP (Av. Prof. Mello Moraes, 1721, Bloco F, sala 22, Cidade Universitária São Paulo, SP - fone: (11) 3097-0529 - e-mail: ceph.ip@usp.br).

Pesquisador

Aluno da Pós-Graduação (regular)

Instituto de Psicologia da USP

\section{CONSENTIMENTO DA PARTICIPAÇÃO}

$\mathrm{Eu}$, , abaixo assinado, concordo em participar do estudo sobre a memória das Comunidades Eclesiais de Base, como sujeito. Fui devidamente informado e esclarecido pelo pesquisador sobre a pesquisa e os procedimentos nela envolvidos.

Local e data:

Nome do participante:

Assinatura do participante: 


\section{APÊNDICE D - Modelo de Revisão do Termo de Consentimento \\ TERMO DE CONSENTIMENTO LIVRE E ESCLARECIDO (REVISÃO QUANTO AO USO DE NOME REAL)}

A revisão do Termo de Consentimento que se segue visa autorizar o uso de seu nome real e a explicitação de sua identidade, de acordo com a vontade livre de sua parte a partir da leitura dos textos produzidos como transcrição de sua entrevista. Após ler e ser esclarecido(a) sobre as informações a seguir, no caso de aceitar tal revisão, assine ao final deste documento, que está em duas vias. Uma delas é sua e a outra é do pesquisador responsável.

1- Foram realizadas entrevistas como parte da pesquisa de mestrado, sob orientação da professora Sueli Damergian, tendo como objetivo registrar e analisar as memórias das pessoas que participaram e/ou participam de Comunidades Eclesiais de Base.

2- As gravações em áudio estão arquivadas com o pesquisador Gustavo Xavier da Silva.

3- Aqui, sua autorização permite a revelação de sua identidade e expressa a vontade livre e esclarecida de manter o uso de seu nome real.

5- O material coletado na pesquisa poderá ser utilizado em uma futura publicação em livro e/ou revista científica ou publicação relacionada ao universo das Comunidades Eclesiais de Base, como publicações de movimentos sociais ou grupos religiosos.

6- A pesquisa não trará nenhum risco a você e nem oferecerá vantagem financeira.

Qualquer dúvida, entrar em contato com Gustavo Xavier pelo telefone (11) 3705-0067 / (11) 9817-9380, ou e-mail guxav@yahoo.com.br, ou diretamente no Comitê de Ética em Pesquisa com Seres Humanos do IPUSP (Av. Prof. Mello Moraes, 1721, Bloco F, sala 22, Cidade Universitária São Paulo, SP - fone: (11) 3097-0529 - e-mail: ceph.ip@usp.br).

Pesquisador

Aluno da Pós-Graduação (regular)

Instituto de Psicologia da USP

\section{CONSENTIMENTO DA PARTICIPAÇÃO}

$\mathrm{Eu}$, , abaixo assinado, concordo em participar do estudo referido e autorizo a revelação de minha identidade real como sujeito. Fui devidamente informado e esclarecido pelo pesquisador sobre a pesquisa e os procedimentos nela envolvidos.

Local e data:

Nome do participante:

Assinatura do participante: 